$$
\text { DOE/mo/25009-T26 }
$$

\title{
EFFECTS OF COAL-DERIVED TRACE SPECIES ON THE PERFORMANCE OF MOLTEN CARBONATE FUEL CELLS
}

TOPICAL REPORT ON THERMOCHEMICAL STUDIES

October, 1991

\begin{abstract}
Submitted by
ENERGY RESEARCH CORPORATION

3 Great Pasture Road

Danbury, CT 06813
\end{abstract}

A. Pigeaud, Principal Investigator

Submitted to

U.S. Department of Energy

Morgantown Energy Technology Center

3610 Collins ferry Road

Morgantown, WV 26507-0880

QC. Williams, COTR

Contract No.

\section{DE-AC21-88MC25009}

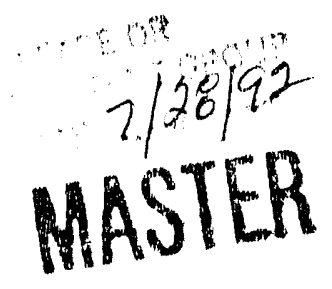


NOTICE

This report was prepared as an account of work sponsored by an agency of the Untted states Government. Neither the United states nor any agency, thereof, nor any of its employees, nor any of its contractors, subcontractors, or their employees, makes any warranty, expressed or implied, or assumes any legal liability or responstbility for any third party's use or the results of such use of any information, apparatus, product or process alsclosed in this report or represents that its use by such a third party would not infringe privately owned rights. 


\section{EXECUTIVE SUMMARY}

The overall objective of the present study was to determine in detail the interaction effects of 10 simultaneously present, coalgas contaminants, both on each other and on components of the Carbonate fuel cell. The primary goal was to assess underlying chemistries and reaction mechanisms which may cause decay in fuel cell performance or endurance as a result of both physico-chemical and/or mechanical interactions with the cell components and internal fuel cell parts. It was found, both from theory and cell. test evidence, that trace contaminant interactions may occur with:

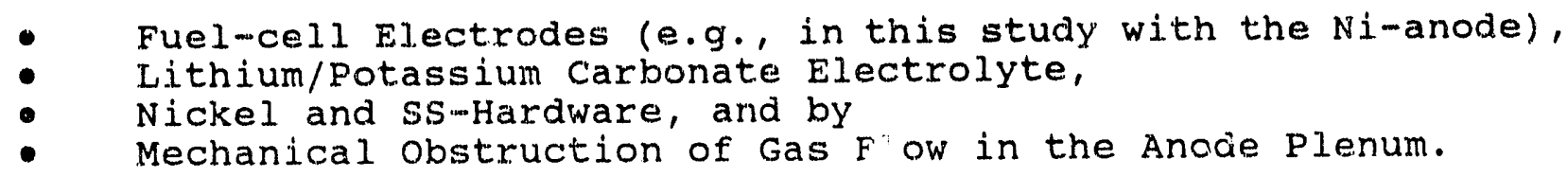

This Topical Report primarily details the thermochemical calculations that were performed, both by hand for individual reactions and by a combined equilibrium SOLGASMIX computer program for simultaneously occurring reactions. This software, by free energy minimization in a closed system, computes all the equilibrium states that may occur inside a fuel cell at $650^{\circ} \mathrm{C}$ in a complex, multiconstituent, assembly of fuel gas components + trace contaminants reacting with active and pissive cell components. Both gaseous and liquid phase (including ionic species) as well as possible solid state reaction products are all treated as being in thermodynamic equilibrium with each other. Conformal Ionic solution Theory (CIST) was employed to obtain these ionic activities and concentrations of the contaminants in the molten carbonate electrolyte.

One project goal was also to determine the most significant contaminant decay mechanisms that result. The latter were established by a continuous feedback process between experimentally obtained data and paraliel thermochemical calculations. An initial binary matrix of all possible gas/liquid/solid trace species interactions, was developed as shown in Table s1. This initial. table of possible compounds that were assumed to exist, has now been modified by addition of dotted circles to show the most important reaction products that were actually found to be present and that are of major significance.

Most of the information feedback process took place between ERC, which generated the experimental data (i.e., the observations and many of the individual chemical calculations), and physical Sciences Inc. (PSI) where the multicomponent thermochemical equilibria were computed for many, parametrically varied, contaminant concentrations. This feedback process of obtaining experimental data and observations and employing thermodynamic analysis before returning to further confirmatory testing, has now culminated in a series of predictive computer models for the different contaminant decay mechanisms. 


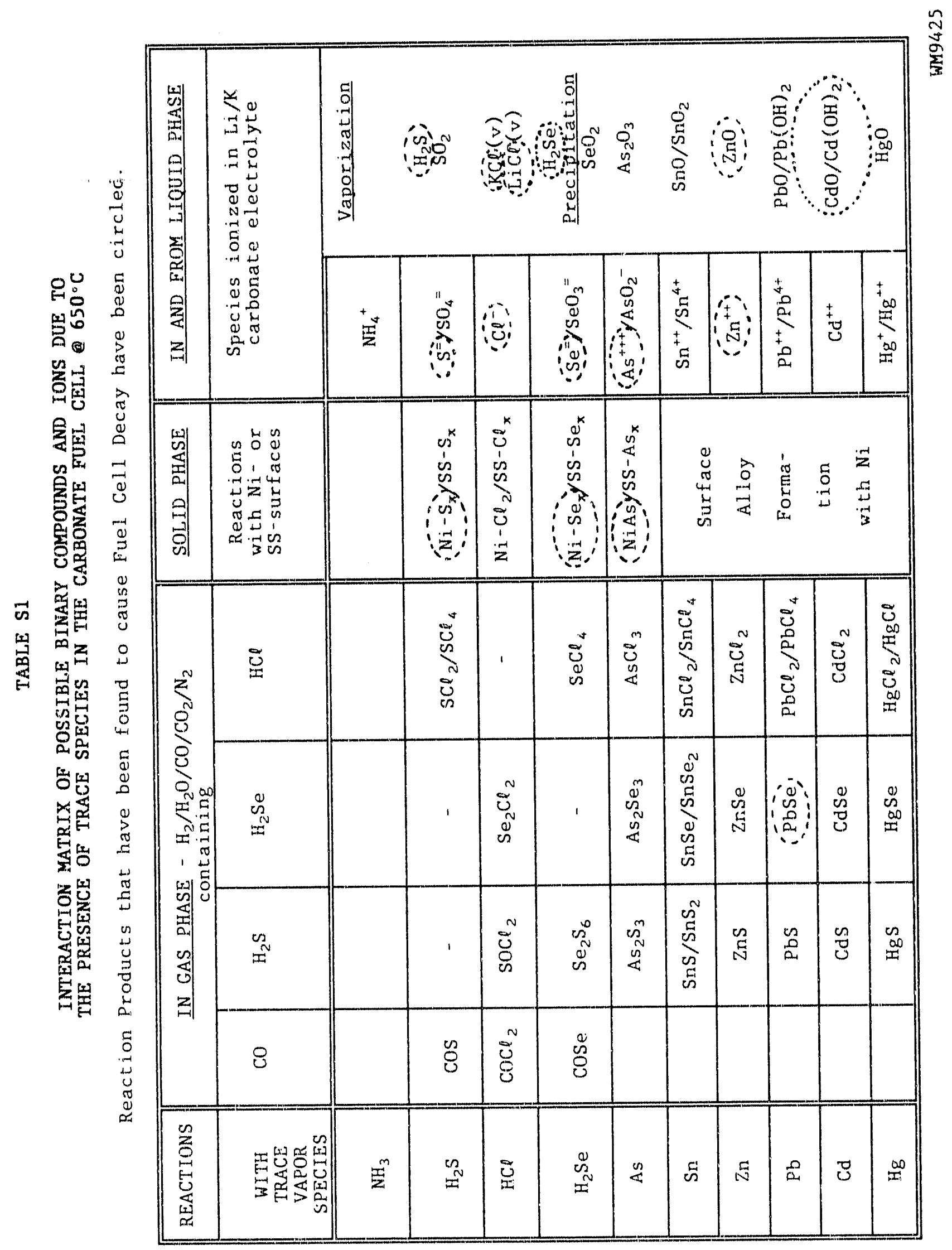


Reporting on the actual 'modeling' phase of the work which will follow later, is primarily concerned with the experimental correlations and modeling computations that have been employed. In the present report, however, the successful effort to define major chemical interactions by purely thermodynamic computations will be discussed. Quantities and types of interaction products that theoretically might form in the electrolyte melt or deposit as a solid product in the molten carbonate fuel cell, were identified. This initial part of the study has therefore provided a good deal of insight in terms of the free energy values of species which can be stable as compounds or ions in a fuel cell environment. This Topical Report, therefore, provides a complete summary of the thermodynamic calculations that support the most significant reactions and interactions among the 1.0 contaminants that were studied.

A thermochemical data-base survey was performed as part of the initial effort to compile background information and free energy data for the various reaction products that were assumed coula form (as illustrated in Table $\mathrm{S} 1$ ); references to the various sources consulted are provided in the Bibliography. In this effort, it was found that there were some data gaps in connection with the molecular species of lead, tin, and arsenic. But most of the free energy data, even at high temperature, for $\mathrm{Hg}, \mathrm{Pb}, \mathrm{Zn}, \mathrm{Cd}, \mathrm{Sn}$ and As species in terms of their simple chlorides and sulfides were found. These are, of course, the most obvious products of interaction that would be of importance in a coal-gas fuel because sulfide and chloride are the two major contaminants.

Even though only limited data were found in some cases for a few possible products, this has not impeded the work. Trace metalic elements have all been assumed to exist both as vapor species in the fuel, as cationic species in the completely ionized carbonate melt, or in pure solid form. The mixing terms of dissolution were generally not as important as the terms involving product formation from the elementary species. But all the required equations for calculating exact or slightly simplified chemical activities for anion/cation species in the melt solution (relative to their activities in the gaseous and solid phases) have been consistently employed. Nevertheless, it may be argued that the few limitations found in existing thermodynamic data for some of the rarer species at high temperature, could make certain thermochemical predictions still somewhat tentative.

As mentioned, the further purpose for the contaminant project. beyond thermochemical analysis, was also to obtain experimental out-of-cell and in-cell evidence (i.e., by Thermogravimetric Analyses and Bench-scale cell T'ests) concerning the exact 'physical mechanisms' which determine a fuel cell's level of contaminant tolerance. Thus there was an important need to both confirm and observe the performance/endurance in fuel cells while these are being exposed to higher and lower levels of contaminant trace species than they can normally tolerate. The various predictive models, some of which have not yet been entirely completed, will be consistent with the experimentally determined levels. 


\section{TABLE OF CONTENTS}

Page

1. INTRODUCTION AND OVERVIEW . . . . . . . . . . . . . . . 1

1.1 SURVEY AND ANALYSis . . . . . . . . . . . . . . . 1

1.2 EXPERIMENTAL . . . . . . . . . . . . . . . . . . 2

1.2.1 Out-of-Celi Experiments 3

1.2.2 Bench-scale Cell Testing 4

1.3 CORRELATIONS AND MODELING • . . . • • • • • . . . 7

2. BACKGROUND FOR THE THERMOCHEMICAL ANALYSIS EFFORT . - 11

2.1 THERMODYNAMIC CALCULATIONS . . . . . . . . . . . . 11

2.2 CORRELATION OF ELEMENTAL REACTIVITIES . . . . . . 13

3. DISCUSSION OF INDIVIDUAL TRACE SPECIES • . . . • . . . 15

3.1 AMMONIA . . . . . . . . . . . . . . . . 15

3.1 .1 Details of $\mathrm{NH}_{3}$ Equilibria 16

HYDROGEN CHLORIDE
3.2 .1 Details of HCl Equilibía

3.2 .2 Details of NaCe(g) Equilibria 25

3.2.3 Details of Combined $\mathrm{HCl} / \mathrm{H}_{2} \mathrm{~S}$ Equilibria 29

3.3 HYDROGEN SULFIDE . . . . . . . . . . . . . . 30

3.3.1 Details of $\mathrm{H}_{2} \mathrm{~S}$ Equilibria 33

3.3.2 Details of $\mathrm{H}_{2} \mathrm{~S} / \mathrm{COS}$ Equilibrium 34

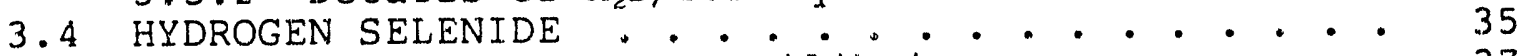

3.4.I Details of $\mathrm{H}_{2} \mathrm{Se}$ Equilibria 37

3.5 ARSENIC . . . . . . . . . . . . . . 41

3.5.1 $\mathrm{As}_{2} / \dot{\mathrm{AsH}}_{3}$ Equilibria with $\mathrm{HCl}, \mathrm{H}_{2} \mathrm{~S}$, and $\mathrm{H}_{2} \mathrm{Se} 46$

3.6 ZINC . . . . . . . . . . . . . . . 47

3.6.1 Zinc Equilibria with $\mathrm{H}_{2} \mathrm{~S}, \mathrm{H}_{2} \mathrm{Se}$, and $\mathrm{HCl} 50$

$3.7 \mathrm{LEAD} \cdot \cdot \cdot \cdot \cdot \cdot \cdot \cdot \cdot \cdot \cdot \cdot \cdot \cdot \cdot \cdot \cdot \cdot \cdot \cdot \cdot 053$

3.7 .1 Lead Equilibria with $\dot{\mathrm{HCl}}^{\circ}, \dot{\mathrm{H}}_{2} \mathrm{~S}$, and $\dot{\mathrm{H}}_{2} \dot{\mathrm{Se}} \cdot 56$

3.8 CADMIUM . . . . . . . . . . . . . . 58

3.8 .1 Cadmium Equilibria with $\dot{\mathrm{HCl}}, \dot{\mathrm{H}_{2} \mathrm{~S}}$, and $\mathrm{H}_{2} \mathrm{Se} \quad 60$

3.9 MERCURY ...................... . 61

4. REFERENCES . . . . . . . . . . . . . . . . . 65

5. APPENDIX . . . . . . . . . . . . . . . . . 69

A. MULTICOMPONENT COAL-GAS CONTAMINANT EQUILIBRIA • • 69

B. $\triangle G$ OF FORMATION OF CONTAMINANTS \& PRODUCTS . . . 108 


\section{LIST OF TABLES}

Table No.

Page

SI INTERACTION MATRIX OF POSSIBLE BINARY COMPOUNDS

AND IONS AS A RESULT OF TRACE SPECIES IN THE

CARBONATE FUEL CELL . . . . . . . . . . . . . . i i

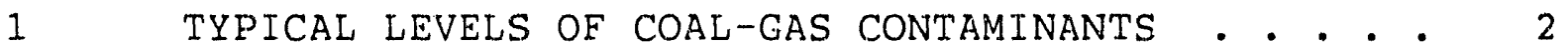

2 LIST OF CONTAMINANT TEST CELLS OPERATED AT ERC IN $300 \mathrm{~cm}^{2}$ BENCH-SCALE CELLS . . . . . . . . . . 5

3 KEY MECHANISMS ASSUMED FOR ANODE PERFORMANCE

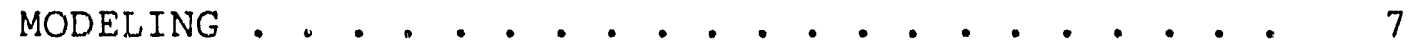

4

ILLUSTRATED PERIODIC TABLE OF THE ELEMENTS . . . . 13

5 EQUILIBRIUM CONSTANTS FOR $\mathrm{NH}_{3}$-FORMATION AT

VARIOUS TEMPERATURES • . • • • • • • • • • • • . 17

$6 \mathrm{NH}_{3}$ CONCENTRATIONS AT VARYING TEMPERATURES AND PRESSURES ...................... 18

7 SUMMARY OF RELATED ANIONIC MELT CONCENTRATIONS AT $650^{\circ} \mathrm{C}$ IN EQUILIBRIUM WITH HCl AND KCl VAPOR SPECIES IN THE GAS PHASE . . . . . . . . . . . . 21

8 CONCENTRATIONS OF HCl $(\mathrm{g}), \mathrm{NaOH}(\mathrm{v})$ AND SATURATED NaC2 VAPOR PRESSURE IN EQUILIBRIUM WITH HUMID COAL-GAS $(20 \%)$. . . . . . . . . . 28

9 SUMMARY OF RELATED ANIONIC MELT CONCENTRATIONS AT $650^{\circ} \mathrm{C}$ IN EQUILIBRIUM WITH $\mathrm{H}_{2} \mathrm{~S}$ AND COS SPECIES IN THE GAS PHASE . . . . . . . . . . . . . . . .

10 SUMMARY OF EQUILIBRIUM SELENIDE AND CARBONATE ANION SPECIES IN CARBONATE ELECTROLYTE \& $650^{\circ} \mathrm{C}$.

11 ACTUAL CELL VOLTAGES, Vă VERSUS CALCULATED VOLTAGES, $\mathrm{V}_{C}$, ON FUEL COINTAMINATED WITH $\mathrm{H}_{2} \mathrm{Se}$ AT $160 \mathrm{~mA} / \mathrm{cm}^{2}$ WITH $75 \% / 50$ FUEL/OXIDANT UTILIZATIONS . . . . . . . . . . . . . . . . 40 40

12 DISTRIBUTION OF GASEOUS ARSENIC MOLECULAR SPECIES

13 SUMMARY OF $\mathrm{Zn}$ SPECIES AND VARIOUS IONS IN EQUILIBRIUM AT $650^{\circ} \mathrm{C}$. . . . . . . . . . . . . . . 48

14 SUMMARY OF Pb SPECIES AND VARIOUS IONS IN

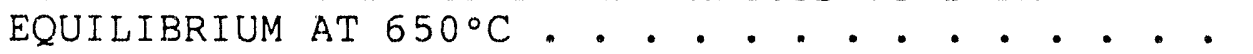




\section{LIST OF TABLES CONT'D}

$\underline{\text { Page }}$

15 SUMMARY OF Cd SPECIES AND VARIOUS IONS IN EQUILIBRIUM AT $650^{\circ} \mathrm{C}$. . . . . . . . . . . . . 59

\section{LIST OF FIGURES}

Figure No.

Page

1 CADMIUM METAL VAPOR VOLATILITY VERSUS $\mathrm{H}_{2} \mathrm{O} / \mathrm{H}_{2}$ RATIO AND TEMPERATURE . . . . . . . . . . . . . 4

2 LIFEGRAPH OF THIRD COMBINED CONTAMINANT TEST: CELL NO. 7-271 . . . . . . . . . . . . 6

3 MODIFICATION OF SOLGASMIX COMPUTER SCHEME FOR EQUILIBRIUM THERMOCHEMICAL CALCULATIONS IN MELT ENVIRONMENT . . . . . . . . . . . . . . 12

4 ARRHENIUS PLOTS OF EQUILIBRIUM PARTIAL PRESSURES FOR $\mathrm{NH}_{3}$ IN COAL-GAS AT DIFFERENT TOTAL

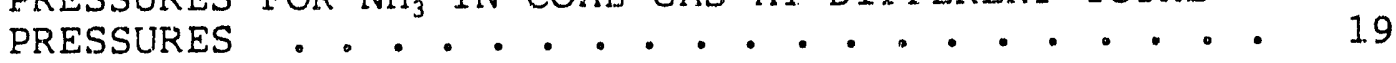

5 VAPOR PRESSURES OF SODIUM CHLORIDE SPECIES IN EQUILIBRIUM WITH $20 \%$ HUMIDIFIED COAL-GAS • • • • . 27 


\section{INTRODUCTION AND OVERVIEW}

our program has made good deal of progress in understanding contaminant effects on carbonate fuel cells. This TOPICAI REPORT summarizes primarily the thermochemical survey and analysis work that was completea during the initial tasks of the project. Experimental cell testing and the final modeling work touched upon in sections 1.2 and 1.3 , is still in progress but will be detailed in the final report of this program.

The present topical report therefore presents an overview of all the thermodynamic analyses and SOLGASMIX computations done for the originally selected 10 contaminants that were to be examined. Accordingly, it is organized, not on a task basis, but by the fundamental thermochemistry and thermodynamics of the individual trace species studied both singly and in combined contaminant interactions and reactions with various fuel gas constituents and fuel cell components.

It has been shown that coal contaminants may impact carbonate fuel cell performance in one or mors of the following ways:

- electrode polarization (Nernst effect)

- carbonate melt volatilization (Electrolyte loss)

- melt compositional changes (K-loss and Trace Ion uptake)

- mechanical obstruction by deposits (porous Anode deactivation)

- corrosion of cell hardware (Contact loss)

Some discussion of these mechanisms will also be included in this report.

\subsection{SURVEY AND ANALYSIS}

A thermodynamic data base search was initially performed to compile the background information and free energy data for a variety of possible reactions that we estimated could occur. References for a number of the sources consulted are shown in section 4 (entries: $12,13,14,28,29,32,33$ ). An in-depth thermochemical analysis was then performed with the 'solgasmIX' computation program for a multiplicity of contaminant reactions with each other and with fuel cell components. A wide range of free energy data available in the literature (cf. Appendix B) was 
assembled for the elements, compounds, and possible interaction products that could be formed in carbonate fuel cell systems by the 10 species listed in Table 1 . So far, this work has focused mainly on the interactions occurring at $650^{\circ} \mathrm{C}$ on the anode (or reducing) side of the carbonate fuel cell. This half of the fuel cell includes the cell's porous $\mathrm{Ni}$-anode together with representative amounts of Li/K-carbonate electrolyte absorbed in that electrode. Many of the possible contaminant interaction effects have been analyzed thermodynamically and when significant were then also tested experimentally.

TABLE 1

TYPICAL LEVELS OF COAL-GAS CONTAMINANTS

(after gasification and after initial hot-gas cleanup)

\begin{tabular}{|c|c|c|}
\hline $\begin{array}{c}\text { Gas \& Vapor Species } \\
\text { (relative amounts) }\end{array}$ & $\begin{array}{l}\text { Without cleanup } \\
\text { (ppm. a >900 } \mathrm{C})\end{array}$ & $\begin{array}{l}\text { After Hot-gas } \\
\text { Cleanup } \\
\text { (est'd ppm at } \\
600^{\circ} \mathrm{C} \text { ) }\end{array}$ \\
\hline $\begin{array}{l}\text { MAJOR: } \\
\qquad \begin{array}{l}\mathrm{NH}_{3} \\
\mathrm{H}_{2} \mathrm{~S} \\
\mathrm{HCl}\end{array} \\
\end{array}$ & $\begin{array}{r}10,000 \\
15,000 \\
500 \\
\end{array}$ & $\begin{array}{r}<3000 \\
<10 \\
>5 \\
\end{array}$ \\
\hline $\begin{array}{l}\text { MINOR: } \\
\text { Zn } \\
\mathrm{Pb} \\
\mathrm{AsH}_{3}\left(\mathrm{As}_{2}\right)\end{array}$ & $\begin{array}{r}100 \\
15 \\
10 \\
\end{array}$ & $\begin{array}{r}<10 \\
<1 \\
<2 \\
\end{array}$ \\
\hline $\begin{array}{c}\text { TRACE: } \\
\mathrm{H}_{2} \mathrm{Se} \\
\mathrm{Cd} \\
\mathrm{Sn} \\
\mathrm{Hg}\end{array}$ & $\begin{array}{c}5 \\
5 \\
3 \\
0.5 \\
\end{array}$ & $\begin{array}{l}? \\
? \\
0 \\
? \\
\end{array}$ \\
\hline
\end{tabular}

WM8764a

\subsection{EXPERIMENTAL}

current and previously obtained experimental information in terms of both out-of-cell and fuel-cell test data were correlated with the above extensive thermochemical analysis effort. This has greatly helped us understand the possible reactions and mechanisms of the various decay effects which we have observed in carbonate fuel cells. 


\subsection{1 out-of-Cel1 Experiments}

Numerous out-of-cell experiments were performed to closely examine trace species volatilities and behavior in humid fuel gas, as well as their interactions with each other and with fuel cell components on the anode side. These experiments were done with a Thermogravimetric Analysis apparatus (TGA) primarily operated in the isothermal mode. The initial volatility experiments were required to provide basic data needed to operate the trace species addition equipment designed to simulate various levels of contamination in a fuel gas, both for bench-scale cell testing and for the out-of-cell experiments.

To obtain the volatility measurements, we accurately monitored weight changes of the solid elemental sources from which the contaminant species would be generated during exposure to a slow flowing gas containing the typical $\mathrm{H}_{2}, \mathrm{CO}_{2}, \mathrm{H}_{2} \mathrm{O}, \mathrm{CO}$ and $\mathrm{N}_{2}$ constituents of coal-gas fuel. To calculate the desired vapor pressures of a contaminant source, we converted the gas transpiration weight-change-rate to equilibrium volatilization into a steadily flowing fuel gas, assuming the gas to become rapidly saturated with the vapor species evolving from the source. Hence, an equilibrium situation was assumed in this approach where the observed weight loss slope indicates steady-state vapor pressure as deriving from either a reaction and/or equilibrium vaporization under well-defined gas composition, flow, and temperature conditions.

For instance, the partial pressure of metallic cd-vapor in the presence of humidified fuel gas is a function of the equilibrium pressures of $\mathrm{H}_{2}$ and $\mathrm{H}_{2} \mathrm{O}$ in the fuel, and of course also its temperature, as given by: $\mathrm{Cd}(\mathrm{V})+\mathrm{H}_{2} \mathrm{O} \rightarrow \mathrm{CdO}(\mathrm{s})+\mathrm{H}_{2}$. Thus, the $\mathrm{H}_{2} \mathrm{O} / \mathrm{H}_{2}$ gas ratio and temperature for different experiments were varied to obtain the equilibrium $\mathrm{Cd}(\mathrm{v})$ pressures as illustrated in Figure 1. These were the type of important initial data that allowed us to determine the temperature at which to operate the "addition reactors" used to realistically simulate the various contaminant concentrations needed for cell testing. One of the data points obtained during bench-scale operation confirms the simulated vapor pressures found by out-of-cell testing as is illustrated in Figure 1. 


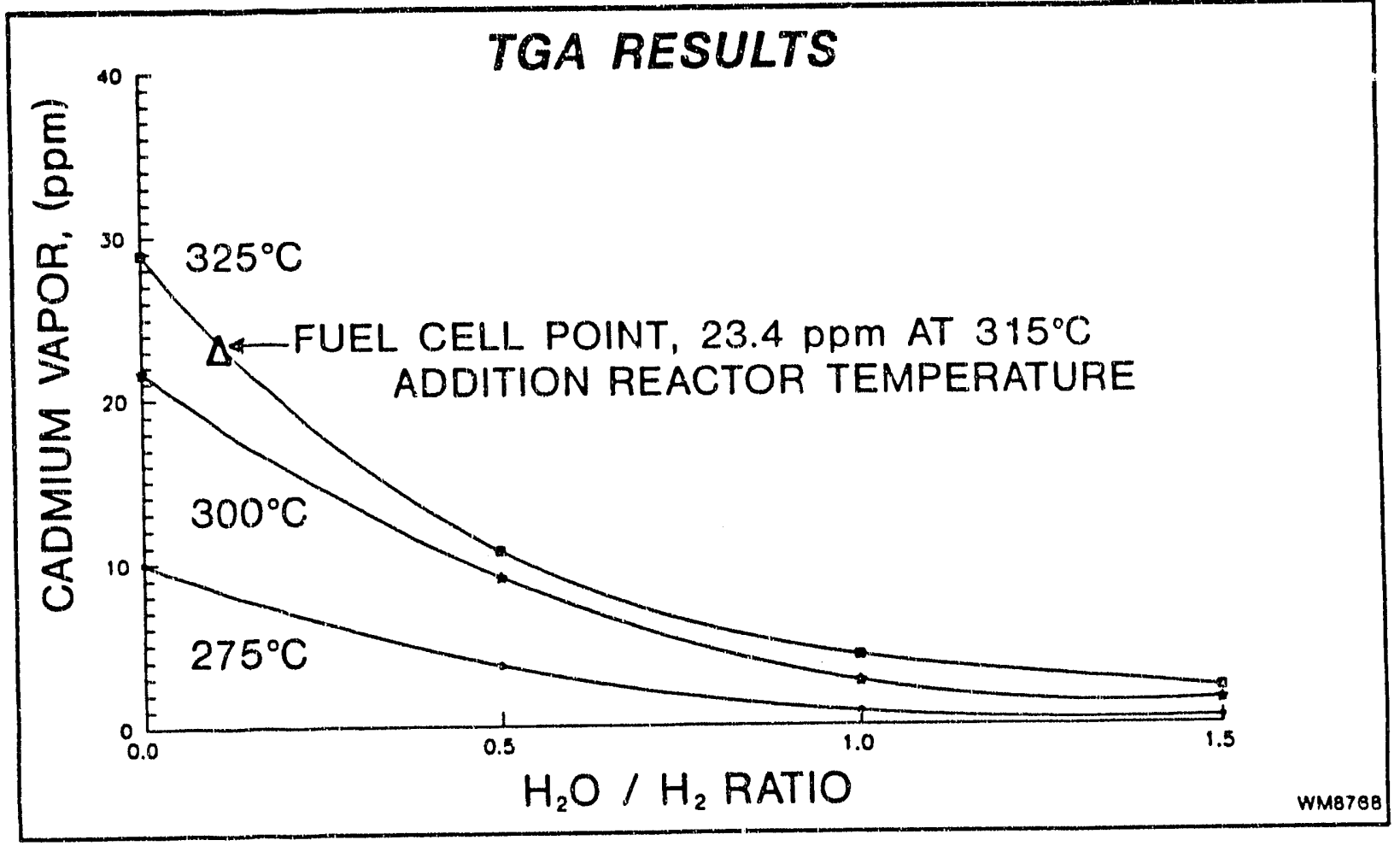

FIGURE 1 CADMIUM METAL VAPOR VOLATILITY VERSUS $\mathrm{H}_{2} \mathrm{O} / \mathrm{H}_{2}$ RATIO AND TEMPERATURE

Thermodynamic Equilibrium Relationships Must Be Determined as a Function of Fuel Humidity and Temperature Before Accurate Vapor concentrations Can Be simulated for Bench-scale cell Testing.

\subsubsection{Bench-scale Cell Testing}

Table 2 presents the 11 bench-scale $\left(300 \mathrm{~cm}^{2}\right)$ fuel cells operated and reported on in recent years as a part of our contaminant effects investigations. The total of more than 35,000 operating hours shown is equivalent to four years of continuous operation for an individual cell. In reality, contaminant testing was accomplished by often operating two to three separate cells side by side, but the total amount of time is still considerably more than was originally planned (e.g., 26,500 hours were planned representative of three years of continuous testing of one cell). Also, from five to seven different contaminants were combined simultaneously in the three last cells operated and reported on. 


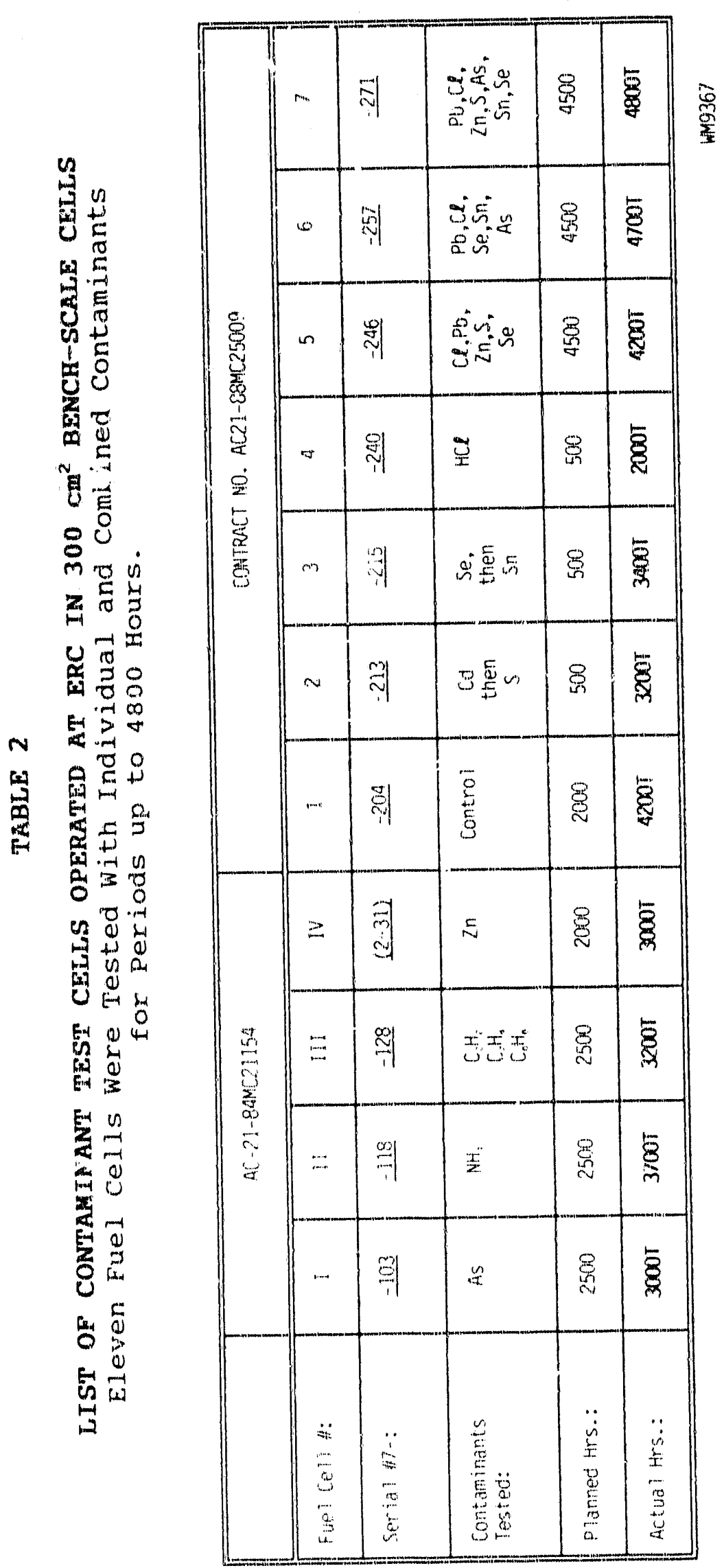


Cell 7-271, the most recent contaminant cell performed rather well as shown in the lifegraph of Figure 2. This is because most of the trace species, except selenium and arsenic, were added at levels somewhat lower than their initially estimated tolerance levels. However, since many of the contaminants used are capable of affecting the cell by different mechanisms which presumably act independently, : $:$ is reasonable to expect that the total effect from the different species has had an additive influence on the long-term, IR-free performance; this has also effectively shown up as a continuous resistance increase in the cell. Additional cell test data will be correlated and presented in a future report entirely denoted to the experimental testing that was done.

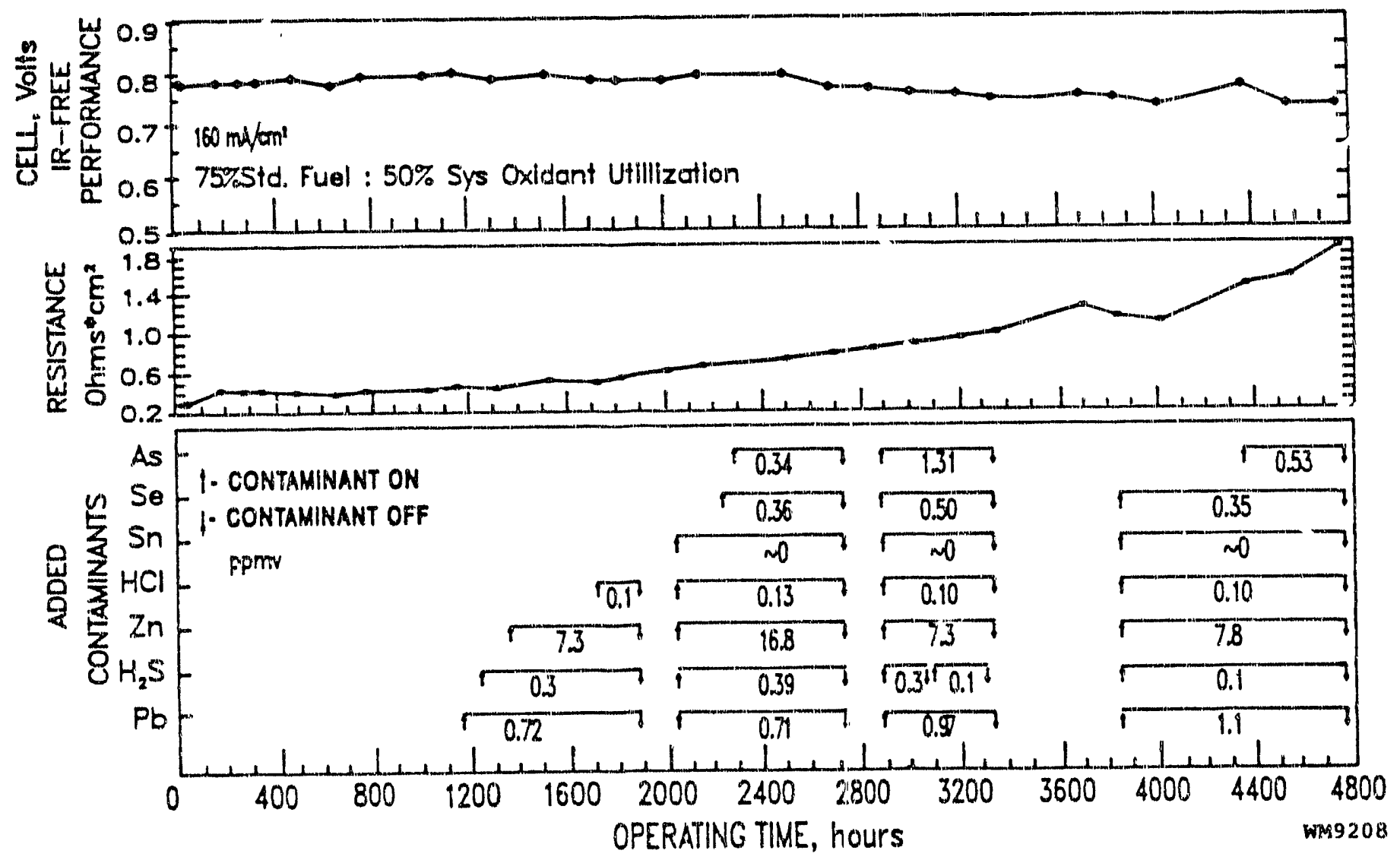

FIGURE 2 IIFEGRAPH OF THIRD COMBINED CONTAMINANT TEST: CELL NO. 7-271

This Cell was Terminated After operating for 4,800 hours on simulated Coal-gas, which Toward The End contained 7 contaminants simultaneously Added for $\mathrm{V}$-rious periods of Time. 


\subsection{CORRELATIONS AND MODELING}

The various effects both observed in out-of-cell experiments and similarly diagnosed in bench-scale ceils were subsequently correlated and summarized into a set of key mechanisms derived from both thermodynamic considerations and empirical evidence. Table 3 illustrates these key mecharisms for the primary six contaminant elements which can significantly affect carbonate fuel cell performance. In the following chapters, each of the elements and the molecular species that may form from them in the carbonate fuel cell. system, are separately examined starting with the fundamental reactivities, then proceeding to the final mechanisms, and finally describing their overall behavior in a cell.

TABLE 3

KEI: MECHANISMS ASSUMED FOR ANODE PERFORMANCE MODELING Fuel Cell Behavior for Six. Important contaminants Has Been Modeled.

\begin{tabular}{|c|c|c|c|}
\hline SPECIES & DECAY MODE & CHPMISTRY & MODELING APPROACH \\
\hline $\mathrm{H}_{2} \mathrm{~S} \& \mathrm{H}_{2} \mathrm{Se}$ & $\begin{array}{l}\text { Reversible Barrier } \\
\text { Formation on Anode }\end{array}$ & $\begin{array}{l}\text { Chemisorption on } \\
\mathrm{Ni} \text { surface of } \mathrm{NiS}_{\pi} \\
\text { and NiSe } \mathrm{Film}_{x}\end{array}$ & $\begin{array}{l}\text { Nerust Threshold } \\
\text { Voltage Changes } \\
\text { due to Surface } \\
\text { Poisoning }\end{array}$ \\
\hline$\left(\mathrm{As}_{3}, \mathrm{As}_{4}\right)$ & $\begin{array}{l}\text { Irreversible Barrier } \\
\text { Formation on Anode }\end{array}$ & $\begin{array}{l}\text { High Resistances, } \\
\text { Stable NiAs Layer } \\
\text { Formation }\end{array}$ & $\begin{array}{l}\text { A Front Develops } \\
\text { which Deactivates } \\
\text { Anode. Starts from } \\
\text { Entry toward Exit }\end{array}$ \\
\hline $\mathrm{HCl}$ & $\begin{array}{l}\text { Cl-Ion Forination and } \\
\text { Subsequent Enhance } \\
\text { ment of Electrolyte } \\
\text { Vaporization }\end{array}$ & $\begin{array}{l}\text { Mainly by KCl } \\
\text { vaporization \& } \\
\text { Li, K } \\
\text { Disproportionation }\end{array}$ & $\begin{array}{l}\text { Electrolyte Loss } \\
\text { from Anode Fill } \\
\text { followed by Melt } \\
\text { Solidification }\end{array}$ \\
\hline $\mathrm{Zn} \& \mathrm{~Pb}$ & $\begin{array}{l}\text { Oxide or Salt } \\
\text { Particle Deposition } \\
\text { can Impede Gas } \\
\text { Diffusion }\end{array}$ & $\begin{array}{l}\operatorname{ZnO}(\mathrm{s}), \operatorname{PbS}(\mathrm{s}) \\
\text { Particie Deposi- } \\
\text { tion from Fuel Gas }\end{array}$ & $\begin{array}{l}\text { Anode Passage \& } \\
\text { Pore Obstruction } \\
\text { occurs in Exit Gas } \\
\text { Region }\end{array}$ \\
\hline
\end{tabular}

WM9238a

Modeling of these mechanisms was begun by calculating important potentials, concentrations and material depositions suggested by the observed and calculated reactions which, to a great extent, were also derivable from equilibrium thermodynamics. Sulfur and selenium, which are closely related in their periodic and electronic structures (i.e., bond-forming activity), were 
successfully modeled as a threshold equilibrium process without involving any spatial or time factors. Strictly Nernstian electrode polarization appears to control the steady-state effects of these two trace species. The inherent reversibility of such a relationship, as a function of concentration and electrode potential was also experimentally observed in the bench-scale cells (as evident in Cells 7-213 and 7-215).

Following this, arsenic was modeled by an approach appropriate to its stoichiometric, chemical-compound-forming reactivity with nickel. As soon as arsenic bearing gases dissolve as ions in the electrolyte, a further reaction with the nickel anode surface occurs. This results in formation of the stable dielectric surface film, NiAs, which acts as an electrode deactivating front growing from inlet to exit with progressive formation of a current barrier behind it. Both a spatial and a time factor are involved in this cumulative, non-recoverable, arsenic decay which was initially observed in actual cell testing and diagnosed by post-test analysis. When cumulative loss of performance due to arsenic has occurred with time, cell voltage remains at the lower level even after the source of contamination is removed from the fuel gas (j.e., no performance recovery is possible as was also found in our original Cell 7-103).

Gaseous hydrochloric acid contamination was alsu modeled using basic thermochemical equilibrium principles and empirical assumptions with regard to the fraction of electrolyte fill in the anode that can initially be affected. Reaction occurs primarily with the electrolyte resulting in the depletion of its potassium and some of its lithium content through the removal of considerable quantities of $\mathrm{KCl}$ and some LiCl vapor from the cell via the gas exit stream. Not only does this result in a loss of total electrolyte stored in the anode - eventhough the carbonate fuel cell anode is not very sensitive to this - but it cumulatively changes the electrolyte composition, which increases the freezing temperature of the carbonate melt. This latter effect may result in sudden electrolyte solidification with obviously catastrophic performance results. Both of these HCl-induced decay aspects have been experimentally observed. Little performance decay was 
initially observed due to $\mathrm{HC} l$ although considerable amounts of $\mathrm{KCl}$ were found in the form of deposits in the exit tubes. A sudden very sharp break and irreversible, current/potential decay then occurred without any chance of maintaining or recovering cell potential by discontinuing the HCl contamination; this was quite evident in our cell 7-240.

Modeling of the last of the metal species has recently been finished. The approach with zinc contamination was to correlate the cumulative deposition of zinc oxide due to its reaction with steam generated in the cell. Steam reacts with metallic zn-vapor over a period or time as it is a combined function of both load and fuel utilization in the cell. Zno particle deposits have been visually observed to deposit, and obstruct the gas exit passages and electrode pores. They first appear at the exit of the cell (this was quite evident in Cell 2-31) and then progressed as a counterflow front toward the fuel entry region, thus cumulatively shutting down active anode surface area in the process. 


\section{BACKGROUND FOR THE THERMOCHEM ICAL ANALYSIS EFFORT}

An initial review of the literature regarding generally known contaminant interactions and experimental evidence of decay did not greatly enhance our understanding of the concentrations and possible reactivities of the selected coal-gas contaminants, or the possible reaction mechanisms that might occur in fuel cells. However, a good deal of thermodynamic (free energy) data were found for many of the plausible reactions and products that could be envisioned. We therefore focused on thorough thermochemical analysis in conjunction with previously developed information from our own cell testing. This approach has led to the preparation of our present theoretical/fundamental understanding of the many possible high-temperature equilibrium reactions in a fuel gas/anode environment when different concentiations of trace contaminants are present.

\subsection{THERMODYNAMIC CALCULATIONS}

An obvious method for global thermochemical calculation of many simultaneous equilibria in a closed system was the SOLGASMIX computer software program that a few years back has become available in the literature (10). This program is capable of calculating the minimum free energy state for complex assemblies of many simultaneously present, condensed solid and gaseous, interacting species occurring within a closed system. In a fuel cell, many reactions can, of course, occur both in the gas phase and with any of the reactive condensed phases such as electrode materials, electrolyte and other fuel cell components. Absorption and ionic reactions may also occur in solution in the liquid electrolyte phase. Thus, to establish true free energy minimization by iterative calculation of the concentrations of each reactant and product in every phase of the entire system, it was necessary to also obtain the complete thermodynamic equilibrium condition for ions in the liquid carbonate phase of the system. This was achieved by Dr. Wilemski at Physical Sciences, Inc. through a further modification of the SOLGASMIX software; namely by calculating and incorporating dissolved ionic activities of the various contaminants in the carbonate melt which represents the liquid phase of the system. 
The SOLGASMIX code was therefore expanded using Conformal Ionic Solution Theory (CIST) to represent ionized species in the liquid carbonate phase (20-27) where such ions are also in equilibrium with their elemental and molecular forms in the solid and gaseous phases of the system. Figure 3 illustrates the equilibrium computational scheme that was developed by Dr. Gerald Wilemski.

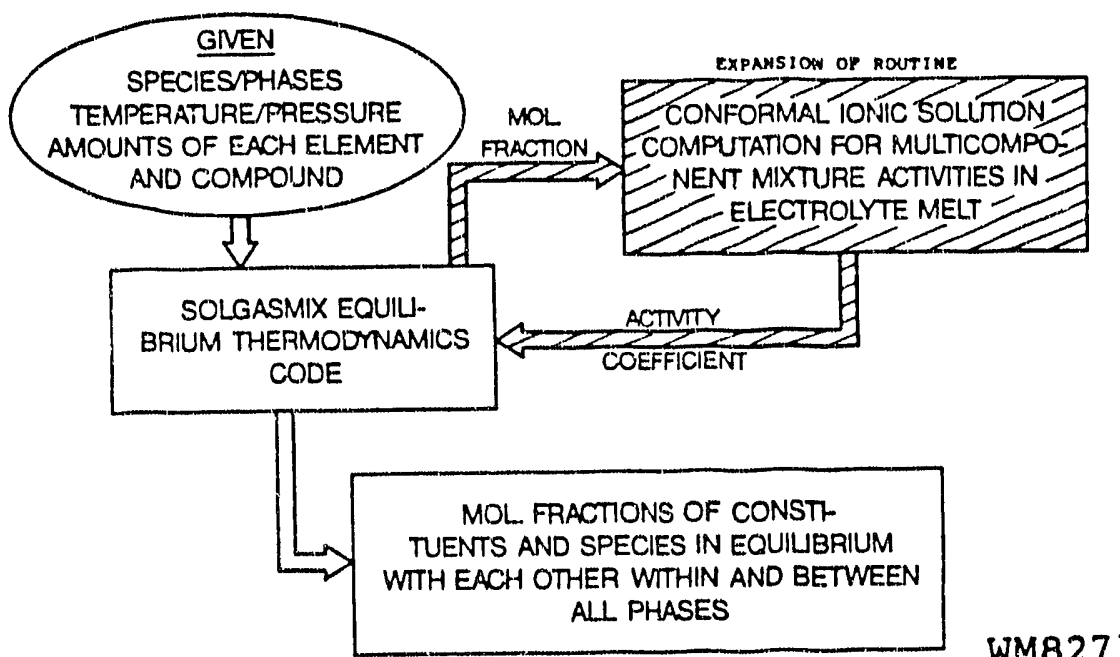

FIGURE 3 MODIFICATION OF SOLGASMIX COMPUTER SCHEME FOR EQUILI-

The crosshatched region represents the routine that was added to the original program to accommodate computation of the liquid phase ionic activities/concentrations which can occur in the electrolyte. overall, the scheme of calculating multicomponent thermodynamic equilibria in an anode fuel cell environment requires the following:

- Start with a realistic concentration of each trace element, fuel gas component or ionized carbonate constituent in the melt, as well as electrode material in the anode plenum,

- Assume a very large gas volume vs. small condensed phase (liquid and solid) volumes to obtain rapid convergence,

- Introduce standard free energy inputs for every possible reactant, reaction product or interaction compound that could be formed at the required temperature/pressure conditions,

- Use "Conformal Ionic Solution Theory" (CIST) to derive ideal ionic solution activities and concentrations for all the possible species in the carbonate melt, 
- Acquire the free energy sum of all these molecular species, elements and ions in the gas/liquid/solid equilibrium system that are consistent with their interaction stoichiometries,

- By trial reaction perturbations, and interation of the computations, find the lowest free-energy state for the total assembly of species present in the different phases of the system.

\subsection{CORRELATION OF ELEMENTAL REACTIVITIES}

In studying the minor metallic trace species and various major metalloid and halide contaminants, it is usually helplul to correlate the known chemical reactivities and affinities of the elements with their position in the Periodic Table (cf. Table 4).

\section{TABLE 4}

\section{ILLUSTRATED PERIODIC TABLE OF THE ELEMENTS}

Possible Volatile Compounds Occur Among the Regular Metals, Metalloids, and Halides. The Ten Elements and Compounds That Were of Concern are Listed Below the Table.

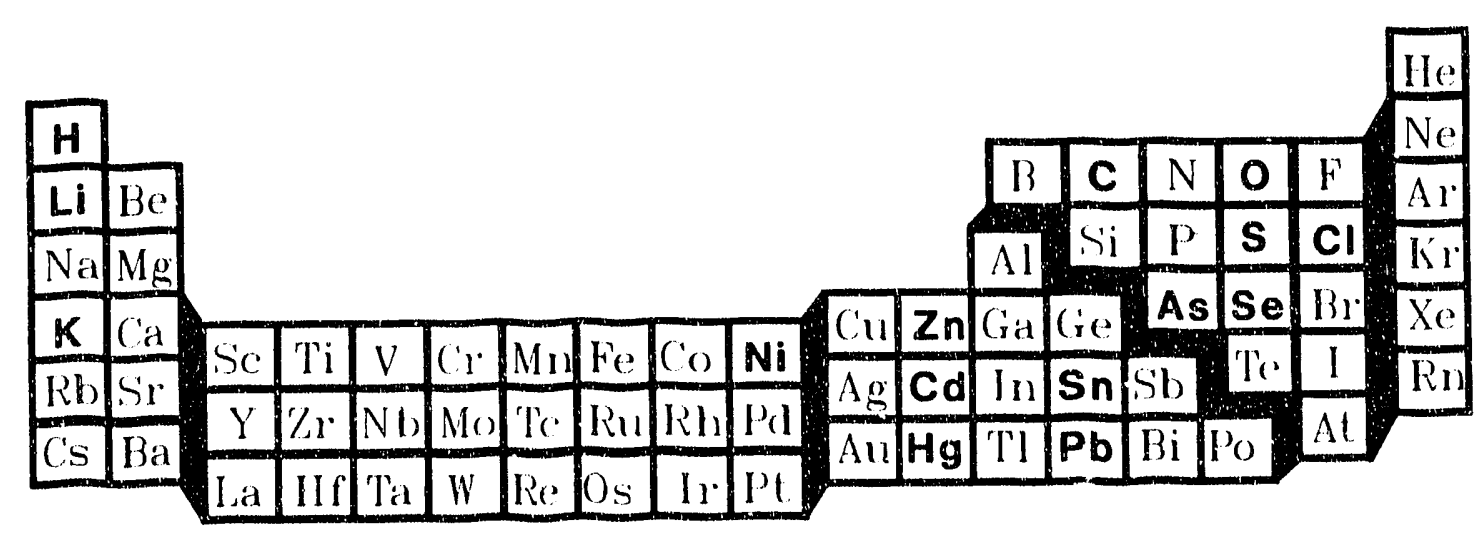

ERC Investigated: $\mathrm{NH}_{3}, \mathrm{HCl}, \mathrm{H}_{2} \mathbf{S}, \mathrm{H}_{2} \mathrm{Se}, \mathrm{AsH}_{3}, \mathrm{~Pb}, \mathbf{Z n}, \mathrm{Cd}, \mathrm{Sn}, \mathrm{Ilg}$

WM9283b

For instance, in the absence of free oxygen (i.e., in a highly reducing fuel gas where oxygen is only associated with the very stable gases: $\mathrm{CO}_{2}, \mathrm{H}_{2} \mathrm{O}$ and $\mathrm{CO}$ ), it is reasonable to expect, especially at high temperatures, that the most electropnsitive elements (viz., hydrogen and the alkalis) will quite strongly tend to combine with the most electronegative elements: viz., the metalloids and halides which will form stable compounds such as $\mathrm{NH}_{3}, \mathrm{HCl}, \mathrm{H}_{2} \mathrm{~S}, \mathrm{H}_{2} \mathrm{Se}, \mathrm{AsH}_{3}$, and also $\mathrm{LiCl}, \mathrm{KCl}, \mathrm{Li} \mathrm{S}_{2} \mathrm{~S}, \mathrm{~K}_{2} \mathrm{~S}$, etc., as well as similar compounds of the selenides and arsenides. 
Regular metals and their vapor species such as $\mathrm{Zn}, \mathrm{Cd}, \mathrm{Hg}, \mathrm{Sn}$, $\mathrm{Pb}$ (and including some transition metals as $\mathrm{Ni}, \mathrm{Fe}$, and $\mathrm{Cr}$ ) at the high temperature of a carbonate fuel cell, remain substantially metallic and inert on the anode (reducing) side when also in contact with alkali metal ions and oxyacids (e.g., carbonate anions). When considering 'metalloid' reactions with each other at, high fuel cell temperature, product formation appears to be minimal, as for instance between sulfur and chlorine. It is for this reason that reactions between $A s, S e, S$, and $C l$, which could occur even before entering the fuel cell, have not been found very important, although they were thermodynamically identified. On the other hand, as will be presented in the following chapters, certain interactions across the stairstep metal/metalloid boundary of the periodic table (e.g., sns, and PbSe) are important and have been carefully examined. other metal/metalloid thermochemically computed reactions (especially of contaminants such as arsenic. interacting with solid $\mathrm{Ni}$ ) have pointed to reactions of special significance in connection with electrode deactivation. 


\section{DISCUSSION OF INDIVIDUAL TRACE SPECIES}

The following sections review the thermochemical evidence of individual contaminant effects on the Molten Carbonate Fuel Cell, The most significant effects of the 10 contaminants studied are presented in great detail. Each section first examines the interaction mechanisms of a single contaminant by itself with the various fuel cell components (viz., the electrodes, the molten carbonate electrolyte, etc.). And at the end of each contaminant section, a discussion is presented of interactions between the different trace species themselves, or with ocher constituents. Reference is made throughout to the SOLGASMIX computed tables in Appendix A showing the multicomponent thermochemical equilibria of the various species at different concentrations both alone and in the presence of various cocontaminants.

\subsection{AMMONIA}

We found that $\mathbf{N H}_{3}$, when present at $54 \mathrm{ppm}$ thermodynamic equilibrium concentration at $650^{\circ} \mathrm{C}$ and 1 atm fuel gas pressure (containing $6 \% \mathrm{~N}_{2}$ and $36 \% \mathrm{H}_{2}$ ), does not interact with fuel cell components or contaminant species. Thermochemically, no free energies for stabie products from $\mathrm{NH}_{3}$ have been found for its interaction with other trace species or fuel cell components in a reducing, hot carbonate, melt environment. Experiments also showed that when a fuel containing $\mathrm{NH}_{3}$ was fed to a bench-scale cell (as in our Cell 7-118) no $\mathrm{NH}_{3}$ was absorbed, or reacted with either nickel, alkali, or carbonate content in the cell.

Basically, therefore, $\mathrm{NH}_{3}$ may be considered a normal equilibrium fuel gas species always present in small quantities in mixtures of $\mathrm{N}_{2}$ and $\mathrm{H}_{2}$ at high temperature. This has little consequence for the carbonate fuel cell or its components. It is merely carried along in all SOLGASMIX computations as one of the species considered but not active with any fuel cell or contaminant species. In other words, from all our cell test evidence, and realizing that sufficiently active catalytic surface is normally available in a gasifier/fuel cell system, there will always be an 
equilibrium ammonia concentration which is merely a function of $\mathrm{T} / \mathrm{P}$ and $\mathrm{H}_{2} / \mathrm{N}_{2}$ content in any fuel gas at a sufficiently high temperature.

This has not always been recognized but explains the data obtained when we cold-blended up to $10,000 \mathrm{ppm}$ ( $1 \mathrm{Vol} \%$ ) $\mathrm{NH}_{3}$ in simulated coal-gas for fuel cell use and rapidly htated it to $650^{\circ}$ to be immediately passed through the cell. When this was performed and again followed by immediate cooling, most of the $\mathrm{NH}_{3}$ remains stable. However, a certain small amount always decomposes, even during the short high-temperature residence time in the cell, presumably with the production of some $\mathrm{N}_{2}$ and $\mathrm{H}_{2}$ content in the gas. This results from the equilibrium tendency of $\mathrm{NH}_{3}$ at high levels and temperatures toward the much lower concentrations (viz. 54 ppm) under normal fuel cell equilibrium conditions. A further examination of the fate of equilibrium $\mathrm{NH}_{3}$ formed at high gasifier temperatures and then being decomposed, follows below. The case studied is one of high temperature/pressure coal gasification followed by a carbonate fuel cell a $650^{\circ} \mathrm{C}$ and atmospheric pressure.

\subsubsection{Details of $\mathrm{NH}_{3}$ Equilitria}

Especially at the high temperature and pressures of a coal gasifier where equilibrium is quickly established, we can use the formation reaction of ammonia to calculate its changing concentration in the flowing gas at various stages of cooling and expansion while it is on its way to the fuel cell:

$$
\mathrm{N}_{2}(\mathrm{~g})+3 \mathrm{H}_{2}(\mathrm{~g}) \stackrel{\mathrm{K}_{\mathrm{T}}}{\longrightarrow} 2 \mathrm{NH}_{3}(\mathrm{~g})
$$

The equilibrium constant, $K_{r}$, can at various temperatures be determined from the difference in standard free energies $\left(\Delta G^{\circ}\right)$ of formation of the reactants and the product, namely:

$$
K_{T}=\exp \cdot{ }_{10}\left[-\Delta G_{T}^{0} /(2.303 \mathrm{RT})\right]
$$

for which four calculations are supplied in Table 5. 
TABLE 5

EQUILIBRIUM CONSTANTS FOR $\mathrm{NH}_{3}$-FORMATION AT VARIOUS TEMPERA'IURES

\begin{tabular}{|c|c|c|c|c|c|}
\hline \multicolumn{2}{|c|}{$\begin{array}{c}\mathrm{T}, \\
\text { Temperature }\end{array}$} & $\begin{array}{l}\Delta \mathrm{G}^{\circ} \text { for } 2 \\
\text { mol of } \mathrm{NH}_{3} \\
\text { formed }(\mathrm{d} T \\
(\mathrm{kJ} / \mathrm{mol})\end{array}$ & $\begin{array}{c}\mathrm{RT} \text { for } \\
\mathrm{R}=8.314 \mathrm{E}-3 \\
\text { in }(\mathrm{kJ} / \mathrm{mol})\end{array}$ & $\frac{-\Delta G^{\circ}}{2.303 R T}$ & $\mathrm{~K}_{\mathrm{T}}$ \\
\hline 627 & 900 & $2 \times 50.25$ & 7.483 & -5.832 & $1.47 E-6$ \\
\hline 727 & 1000 & $2 \times 61.91$ & 8.314 & -6.465 & $0.34 \mathrm{E}-6$ \\
\hline 927 & 1200 & $2 \times 85.23$ & 9.977 & -7.419 & $38 E-9$ \\
\hline 1227 & 1500 & $2 \times 120.7$ & 12.47 & -8.406 & $3.9 E-9$ \\
\hline
\end{tabular}

WM9 360

In terms of the activities, $a_{i} ;$ partial pressures, $p_{i} ;$ and concentrations, $c_{i} ;$ of the individual participating species, we have for the ideal gas case: $a_{i}=p_{i}=c_{i} P$, where $P$ is the total pressure of all gases in the system, including any nonparticipating (i.e., diluent) gases. Hence, the mass balance equilibrium may be written:

$$
\mathrm{K}_{\mathrm{T}}=\frac{\left(\mathrm{C}_{\mathrm{NH}_{3}} \cdot \mathrm{P}\right)^{2}}{\mathrm{C}_{\mathrm{N}_{2}} \cdot \mathrm{C}_{\mathrm{H}_{2}}^{3} \cdot \mathrm{P}^{4}}
$$

from which the ammonia species as a $f(T, P, C)$ can be derived in terms of mol. fraction concentration as follows:

$$
\mathrm{C}_{\mathrm{NH}_{3}}=\mathrm{P}\left(\mathrm{K}_{\mathrm{T}} \cdot \mathrm{C}_{\mathrm{N}_{2}} \cdot \mathrm{C}_{\mathrm{H}_{2}}^{3}\right)^{1 / 2}
$$

A tabulation of values at different $T$ and $P$ for coal-gas from an $\mathrm{O}_{2}$-blown gasifier $\left(6 \% \mathrm{~N}_{2}, 36 \% \mathrm{H}_{2}\right)$ is shown in Table 6 . It is assumed for convenience that the $\mathrm{H}_{2}$ concentration is essentially constant because only small changes occur in the watergas Shift Equilibrium (i.e., exchange of $\mathrm{H}_{2}$ for $\mathrm{CO}$ ) from one temperature to the next.

In contrast to the watergas shift reaction, which is not pressure sensitive, the total pressure (as shown by Equation 1), has a large effect on $\mathrm{NH}_{3}$ formation. In this respect, it is interesting to observe that if coal gasifier fuel is cooled, 


\section{$\mathrm{NH}_{3}$ CONCENTRATIONS AT VARYING TEMPERATURES AND PRESSURES}

\begin{tabular}{||c|c|c|c|}
\hline \multirow{2}{*}{$\begin{array}{c}\text { Temperature } \\
{ }^{\circ} \mathrm{C}\end{array}$} & $\begin{array}{c}\mathrm{C}_{\mathrm{NH}_{3}} \text { in ppm for } \mathrm{O}_{2} \text {-blown coal-gas containing } \\
6 \% \mathrm{~N}_{2} / 36 \% \mathrm{H}_{2} \text { with total gas pressure of : }\end{array}$ \\
\cline { 2 - 4 } & $1 \mathrm{Atm}$. & $10 \mathrm{Atm}$. & 100 Atm. \\
\hline 672 & 64 & 640 & 6400 \\
\hline 727 & 31 & 310 & 3100 \\
\hline 927 & 10 & 100 & 1000 \\
\hline 1227 & 3.3 & 33 & 300 \\
\hline
\end{tabular}

WM9361

under high pressure, to the approximate temperature of a fuel cell, it will probably contain a large equilibrium amount of ammonia: i.e., $\mathrm{NH}_{3}$ is at 0.64 atm. partial pressure at 100 atm. total pressure representing 6400 ppm concentration at that point. But if the coal-gas is rapidly expanded at high temperature down to 1 atm. fuel cell pressure, it will contain much less ammonia than if the coal-gas were to be first cooled and then expanded. Namely, if expansion comes first and afterwards cooling to fuel cell compatible temperature, the gas will contain much less $\mathrm{NH}_{3}$, probably between 10 to $64 \mathrm{ppm}$ at $1 \mathrm{~atm}$. of total coal-gas pressure. The difference between the two pathways is due to maintaining rapid kinetics in the latter case of high temperature expansion which is where the greatest gain lies in decreasing $\mathrm{NH}_{3}$ content.

Figure 4 shows these paths on Arrhenius plots for both an $\mathrm{O}_{2}-$ blown coal-gas, and an air-blown situation. Regardless of these considerations, however, one may conclude from bench-scale fuel cell tests operated with up to $10,000 \mathrm{ppm} \mathrm{NH}_{3}$ showing essentially no effect, that ammonia - at whatever high or frozen-in equilibrium concentration it exists - will not be of great concern to the carbonate fuel cell. The SOLGASMIX computed concentration for $\mathrm{NH}_{3}$ at $650^{\circ} \mathrm{C}$ differs slightly from the above calculated value because of the presence of fewer gases (i.e., no $\mathrm{H}_{2} \mathrm{O}, \mathrm{CO}, \mathrm{CO}_{2}$, etc.) in the latter case. 


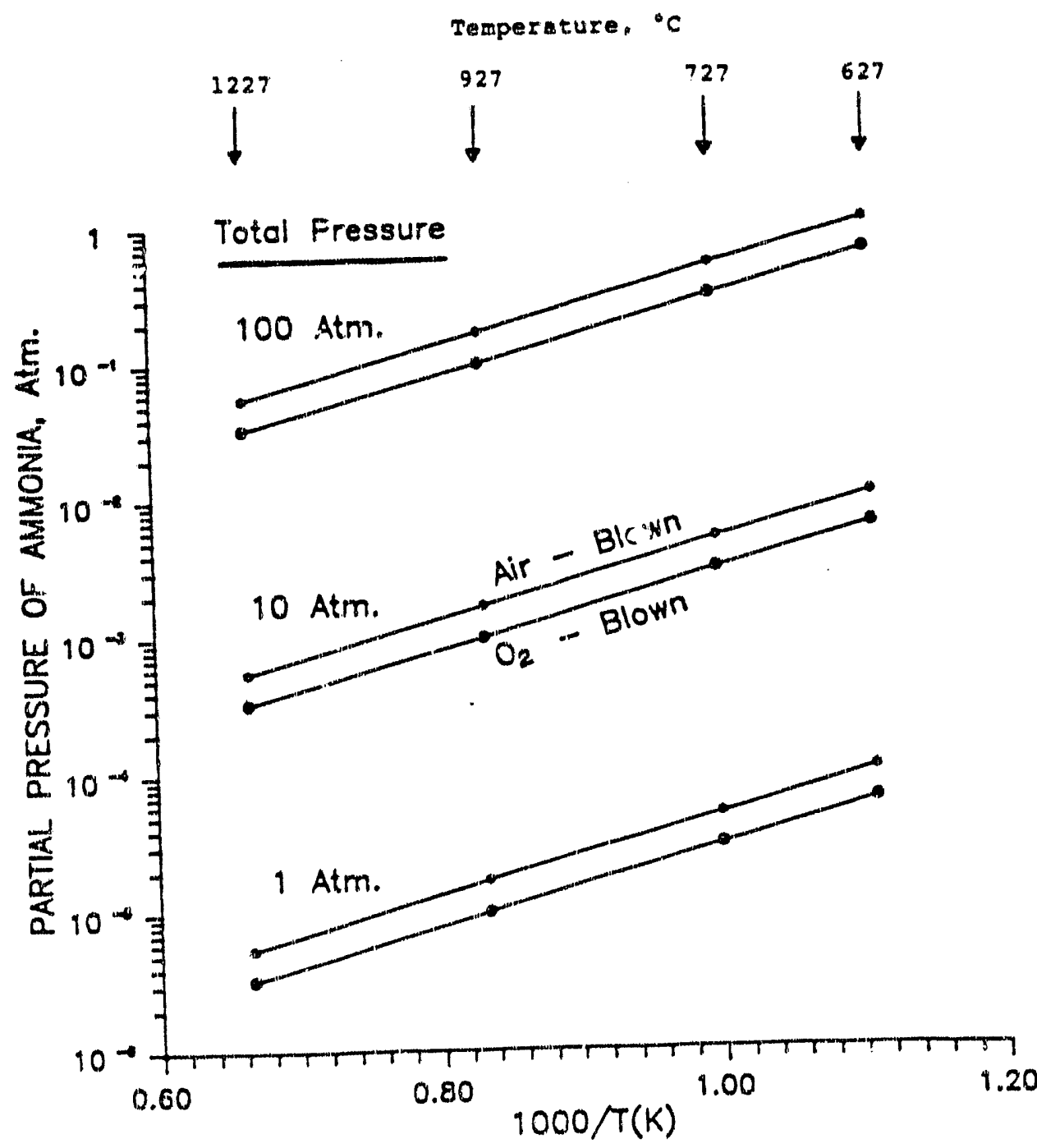

MC1060

FIGURE 4 ARRHENIUS PLOTS OF EQUILIBRIUM PARTIAL PRESSURES FOR NH IN COAL-GAS AT DIFEERENT TOTAL PRESSURES

Large concentrations of $\mathrm{NH}_{3}$ can be present at High Total pressure.

Hence, in Integrated IGFC systems where coal-gas is utilized at moderate temperatures and pressures, the question of ammonia content and its subsequent contaminant effect in terms of transformation to $\mathrm{NO}_{x}$ can be essentially ignored. The mild environment within a fuel cell even on the cathode side (i.e." $\left.\sim 650^{\circ} \mathrm{C}\right)$, is not capable of converting $\mathrm{NH}_{3}$ to $\mathrm{NO}_{x}$. This contrasts with coal-gas used as the fuel for thermal engines or carnot type systems where high-temperature/pressure combustion conditions are required for high efficiency. Under those conditions, large (equilibrium) amounts of high"pressure $\mathrm{NH}_{3}$ cannot be tolerated in fuel because it will rapidly convert to $\mathrm{NO}_{\mathrm{x}}$ upon oxidation above 
$1500^{\circ} \mathrm{C}$. Since no interaction of gastous $\mathrm{NH}_{3}$ with fuel cell components was found (aiso confirming the thermochemical analysis), no further mention will be made of this species as an important contaminant with regard to the Molten Carbonate Fuel Cell.

\subsection{HIDROGEN CELORIDE}

of the halides, only $\mathrm{HCl}$ has been studied both thermochemically and experimentally in this program. It represents the most typical and abundant halide that may contaminate coal-gas at levels up to $500 \mathrm{ppm}$. From some original work reported in the literature (4), it was deduced that an operating level of $0.1 \mathrm{ppm}$ might be tolerable in fuel on the anode side of the carbonate fuel cell, but that if the anode exit gas is recycled to the cathode, it must not contain more than $10 \mathrm{ppb} \mathrm{HCl}$.

On the anode side, a plausible electrode polarization mechanism could se chemisorption on the nickel anode forming a chloride surface compound (i.e., NiCl $)$ :

$$
x \mathrm{Cl}^{-}(l)+\mathrm{Ni}(\mathrm{C}) \longleftrightarrow \mathrm{NiCl}_{x}(\operatorname{surf.})+\mathrm{xe}
$$

But, although polarization could be of concern, the major effect of volatile chloride contaminants we have experimentally found is the removal of potassium from the electrolyte. This has not been widely reported prior to the current experimental studies at ERC, which also include thermochemical computations performed by PSI using the enhanced SOLGASMIX (SGM-CIS) program. These efforts have clearly shown that the major part of HCe interaction with a carbonate fuel cell is with the potassium in the electrolyte. HCe at only $1 \mathrm{ppm}$ in the gas phase can dissolve to a considerable extent in molten carbonate, forming as much as 15 molo chloride ion on total 'anion' content (100\%) of the electrolyte; this is clearly illustrated in Table II.I.C of the computer results in Appendix $A$.

A summary of this Appendix tabulation (i.e., from parts A, B, and $C)$ is shown in table 7 below. It is noted from these thermochemical computations, that upon addition of gaseous HCe in small stages to the fuel (going from 1 ppb to 3 ppm), the 
"equilibrium" chloride ion content in the electrolyte - as a mol\% of the total melt anion fraction - increases drastically. The hydroxyl ion content (i.e., an indicator of the electrolyte's basicity) also increases somewhat.

TABLE 7

SUMMARY OF RELATED ANIONIC MELT CONCENTRATIONS AT $650^{\circ} \mathrm{C}$ IN EOUILIBRIUM WITH HC $P$ AND KC $\ell$ VAPOR SPECIES IN THE GAS PHASE The Total of Liquid Ionic Species in the Melt for Each Line in the Table Adds Up to $100 \%$ Anion Content.

\begin{tabular}{|c|c|c|c|c|}
\hline $\begin{array}{c}\mathrm{HCl}(\mathrm{g}) \\
\mathrm{ppm}\end{array}$ & $\begin{array}{c}\mathrm{Cl}^{-}(\ell) \\
\mathrm{mol} q\end{array}$ & $\begin{array}{c}\mathrm{CO}_{3}{ }^{2}(\ell) \\
\mathrm{mol}\end{array}$ & $\begin{array}{c}\mathrm{OH}^{-}(\ell) \\
\mathrm{mol} \%\end{array}$ & $\begin{array}{c}\mathrm{KCl}(\mathrm{g}) \\
\mathrm{ppm}\end{array}$ \\
\hline 0.0 & 0.0 & 98.8 & 1.18 & 0.0 \\
\hline 0.001 & 0.019 & 98.8 & 1.18 & 0.023 \\
\hline 0.005 & 0.094 & 98.7 & 1.18 & 0.115 \\
\hline 0.01 & 0.19 & 98.6 & 1.18 & 0.228 \\
\hline 0.05 & 0.93 & 97.9 & 1.19 & 1.11 \\
\hline 0.1 & 1.84 & 97.0 & 1.19 & 2.13 \\
\hline 0.5 & 8.29 & 90.5 & 1.22 & 7.93 \\
\hline 1.0 & 15.1 & 83.6 & 1.26 & 11.7 \\
\hline 2.0 & 25.1 & 73.6 & 1.32 & 14.0 \\
\hline 3.0 & 32.7 & 65.9 & 1.37 & 14.1 \\
\hline
\end{tabular}

WM9362

Thus, as a consequence of major equilibrium changes in the anionic content of the melt due to continuous chloride absorption from only 1 ppm gaseous $\mathrm{HCl}$ in the fuel, the composition of the electrolyte can be strongly affected in terms of its carbonate content. The carbonate concentration of the melt can be reduced to the point that, even slightly above $0.5 \mathrm{ppm}$ gaseous HCl presence in fuel, the melt shows a definite tendency toward so-called electrolyte chloridization (i.e., $10 \%$ alkali chloride content in the carbonate melt). Moreover, at that point, the equilibrium concentration of $\mathrm{KCl}$ in the gas phase increases so much (to $\sim 8 \mathrm{ppm}$ ) that a large amount of potassium is being removed from the electrolyte if gas/liquid equilibration, and fuel gas flow through 
the cell, are relatively rapid. The reactions for the overall process of $\mathrm{HCl} / \mathrm{KCl}$ volatilization from the molten carbonate electrolyte may be assumed to be:

$$
\begin{gathered}
2 \mathrm{HCl}(\mathrm{g})+\mathrm{CO}_{3}{ }^{=}(\mathrm{l}) \longleftrightarrow 2 \mathrm{Cl}^{-}(\mathrm{l})+\mathrm{H}_{2} \mathrm{O}(\mathrm{g})+\mathrm{CO}_{2}(\mathrm{~g}) \\
\mathrm{Cl}^{-}(\mathrm{l})+\mathrm{K}^{+}(\mathrm{l}) \longleftrightarrow \mathrm{KCl}(\mathrm{g})
\end{gathered}
$$

These observations will be further discussed when the complete performance modeling work in terms of halide effects are reported.

\subsubsection{Details of HCP Equilibria}

Looking in greater detail at Table $I I \cdot 1$ ( $A, B$, and $C$ ) in Appendix $A$, we note that under the $\varnothing$-column are listed: under Section $A$, the baseline gas partial pressures; under section $B$, the 'activities' of all the possible dissolved liquid compounds that can be present (from Conformal Ionic solution computation); and under section $C$, the cation and anion fractions that these activities represent in the melt (assuming complete ionization). Columns 1 through 9 provide the corresponding concentrations of all the associated species in equilibrium with the various amounts of gaseous $\mathrm{HCl}$ when this ranges from $1 \mathrm{ppb}$ to $3 \mathrm{ppm}$ in the gas phase.

It was first observed that, as the gas phase level of $\mathrm{HCl}$ increases, the partial pressures of $\mathrm{K}(\mathrm{g})$ and the various gaseous $\mathrm{K}-$ and $\mathrm{Li}$-hydroxide species decreases; since $\mathrm{Li}(\mathrm{g})$ exists only to such a small extent $(\mathrm{e} . \mathrm{g} .,<1.0 \mathrm{E}-30)$ it is not shown in the printouts. This may be a direct consequence of the increasing stability of dissolved $\mathrm{KOH}$ and $\mathrm{LiOH}$ species in the melt when chloride ion level. increases. The increased stability of these liquid hydroxide species is also manifested in their decreasing activities as shown in the B-Table. Upon checking the ion fractions in the C Table, we find that the equilibrium chloride ion concentration in the electrolyte, as previously mentioned, can thus become remarkably high. It starts with 1 ppb in the gas phase, providing about 0.02 molz chloride concentration in the liquid phase. This then increases steadily when final gaseous HCl levels reach 1,2 , and 3 ppm, providing a chloride ion content in the melt in excess of $15 \%$, 
$25 \%$, and almost $33 \%$ of the total anion content, respectively. Besides the obvious dilution effect due to replacement of the carbonate moiety in the melt by chloride, a detrimental $\mathrm{Ni-}$ electrode "corrosion" effect is also shown at high chlorine levels ( 3 ppm $\mathrm{HCl}$ ) by the 12-fold increase in $\mathrm{Ni}^{++}$cation concentration in the melt. Moderate increases in the hydroxide and oxide ion levels are also shown in Table II. $1 \cdot \mathrm{C}$.

However, the most significant adverse consequence also evident from these calculations is the large increase in electrolyte volatility as a result of the high partial pressures of volatile alkali chlorides that form even at modest $\mathrm{HCl}$ levels. At only 10 $\mathrm{ppb} \mathrm{HCl}$, we see in column 3 of the A-table that the partial pressure of $\mathrm{KCl}(\mathrm{g})$ is already twice that of the original $\mathrm{KOH}(\mathrm{g})$ value (cf. the $\phi$-column) even though the $\mathrm{LiCl}(\mathrm{g})$ concentration has only slightly increased over $\mathrm{LiOH}(\mathrm{g})$. Continued increases of $\mathrm{HCl}$ then lead to very high $\mathrm{KCl}$ vapor pressures. Hence, as a result of the higher than usual melt vapor pressure, especially due to KCe volatility, we can expect rapid loss of potassium content from the cell with obvious consequences for long-term performance which, in fact, has been experimentally observed in a number of cell tests (particularly as shown by our Cell 7-240).

It may also be noted in the $\mathrm{B}$-table that the high $\mathrm{KCl}$ vapor pressure correlates with a high activity (i.e., low stability) of $\mathrm{KCl}$ in the melt, which conforms to proper thermodynamic equilibrium behavior. The highest $\mathrm{KC} \ell(\ell)$ activity listed in the $\mathrm{B}$ table is 0.59 (column 9) in equilibrium with $3 \mathrm{ppm} \mathrm{HCl(g).} \mathrm{This} \mathrm{is} \mathrm{rather}$ close to the calculated melt saturation value of 0.677 at which solid $\mathrm{KCl}(\mathrm{s})$ would begin to precipitate from the melt; this correlates with $\mathrm{KCl}(\mathrm{g})$ reaching its saturation pressure of $16 \mathrm{ppm}$ in a fuel at $650^{\circ} \mathrm{C}$. Given the slight uncertainties in thermodynamic data underlying this melt model, we should probably consider such high calculated melt activities as a warning of the additional possibility of $\mathrm{KCl}(\mathrm{s})$ precipitating in electrolyte besides already being rapidly removed frorn it in gaseous form with only $0.5 \mathrm{ppm} \mathrm{HCl}(\mathrm{g})$ present as the fuel contaminant. 
Looking at the bottom of the Appendix II. 1 tabulation, the Ctable, one sees no indication of solid $\mathrm{NiCl}_{2}$ forming. This is not surprising when the following reaction is considered:

$$
2 \mathrm{HCl}(\mathrm{g})+\mathrm{Ni}(\mathrm{C}) \longleftrightarrow \mathrm{NiCl}_{2}(\mathrm{C})+\mathrm{H}_{2}(\mathrm{~g})
$$

We can write the $\Delta G$ for this reaction as:

$$
\Delta \mathrm{G}=33.62 \mathrm{~kJ} / \mathrm{mol}+\mathrm{RTInP}_{\mathrm{H}_{2}}-2 \mathrm{RT} 1 \mathrm{np} \mathrm{HCl}_{\mathrm{HCl}}
$$

from which we can derive that the equilibrium partial pressure of $\mathrm{HCl}$ needed to produce solid $\mathrm{NiCl}_{2}$ is given by:

$$
\mathrm{p}_{\mathrm{HCl}}=\left(\mathrm{p}_{\mathrm{H}_{2}}\right)^{1 / 2} \times 0.012
$$

Hence, at 0.36 atm of $\mathrm{H}_{2}$, nearly $7200 \mathrm{ppm}$ of $\mathrm{HCl}$ gaseous contamination would be required before solid $\mathrm{NiCl}_{2}$ can be directly formed from the gas phase on solid nickel at $650^{\circ} \mathrm{C}$.

If we now also regard the possibility of an electrochemical interaction mechanism due to dissolved chloride ion reacting with a wetted metaliic $\mathrm{Ni}$-anode,

$$
2 \mathrm{Cl}^{-}+\mathrm{Ni}(\mathrm{C}) \longleftrightarrow \mathrm{NiCl}_{2}(\mathrm{C})+2 \mathrm{e}^{-}
$$

we can determine the overpotential required for $\mathrm{Eq} \cdot 11$ (the Eq. 8 analogue) to proceed if it is electrochemically driven. For instance, at $0.36 \mathrm{~atm}$ of $\mathrm{H}_{2}$ partial pressure and $0.1 \times 10^{-6}$ atm (i.e., $0.1 \mathrm{ppm}$ ) of gaseous $\mathrm{HCl}, \mathrm{Eq} .9$ requires an additional $\Delta \mathrm{G}=$ $239.6 \mathrm{~kJ} / \mathrm{mol}$ for the reaction to take place under the dissolved trace contaminant conditions. Thus, $2.73 .2 \mathrm{~kJ} / \mathrm{mol}$ total free energy difference must exist if we assume activity equilibrium between HCe in the gas phase (and $\mathrm{Cl}^{-}$ions in the melt phase) in equilibrium with $\mathrm{NiCl}_{2}(\mathrm{c})$. This represents an equivalent overpotential $\mathrm{V}=$ $\Delta \mathrm{G} / \mathrm{nF}=1.42$ volt.

Thus, in order for the $\mathrm{NiCl}_{2}$ reaction to proceed, an electrochemically countering overpotential would have to be applied to make the $\Delta G$ more negative. Or, in other words, with the passage of current, the potential across the electric double layer at the electrode/electrolyte interface must be made more positive by this amount compared to its open circuit value. This high theoretical. 
value overwhelmingly rules out such a possibility, since the typical open circuit potential at the MCFC anode is $\sim 1 \mathrm{~V}$ in the presence of an average fuel gas.

However, it is not quite so easy to rule out the possibility of electrochemical adsorption of $\mathrm{C} e^{-}$ion to form some sort of $\mathrm{NiCl}_{x}$ surface species which could be more stable than bulk $\mathrm{NiCl}_{2}(\mathrm{c})$. In this case, the electrochemical reaction:

$$
\mathrm{XCl}^{-}+\mathrm{Ni}(\mathrm{c}) \longleftrightarrow \mathrm{NiCl}_{x}(\operatorname{surf})+\mathrm{Xe}^{-}
$$

could proceed at a much lower overpotential and lead to electrode poisoning in a manner similar to the occurrence of sulfide and selenide polarization.

In sum, the equilibrium levels of chloride ion in the melt can be quite high, easily exceeding 2 molo of the anion content, when

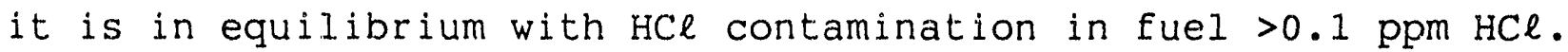
This concentrating effect of chloride in the melt, besides having major consequences in terms of increased electrolyte volatility, is also expected to affect the electrolyte conductivity and may change the electrochemical kinetics of hydrogen oxidation, either directly via poisoning of the electrode surface or indirectly by altering the iransport properties of carbonate ion and the other dissolved reactant and product species. The above calculated results show that to achieve long cell life, one must keep HCl concentration at or well below the $0.1 \mathrm{ppm}$ level in fuel gas. This is because all of it will potentially be absorbed and converted to chloride ion and $\mathrm{KCl}(\mathrm{g})$, causing a great deal of electrolyte loss and thus permanently affecting the fuel cell in the long term.

\subsubsection{Details of NaCl(g) Equilibria}

An additional investigation (not part of the original project) into the theoretical amounts, stability and fate, of sodium chloride and its reaction products formed during coal gasification was made to learn how NaCl decomposition in coal--gas might affect a fuel cell. Although sodium was not one of the original 10 trace species to be investigated, it became of particular interest because NaCe is usually a major chlorine type coal contaminant and 
is therefore related to the potential amounts of HCl released in a realistic situation. Sodium chloride, vaporized from a gasifier operating on high $\mathrm{NaCl}$ content coal and then cooled to fuel cell temperature, is not likely to decompose into the individual sodium and chlorine elements in a reducing gas environment. However, under gasifier conditions, NaCl may have a saturation vapor pressure in equilibrium with its condensed species of $5.8 \times 10^{-2}$ atm. at $1127^{\circ} \mathrm{C}$ and then it decreases to $4 \times 10^{-6}$ atm. at $627^{\circ} \mathrm{C}$. Also, $\mathrm{NaCl}(\mathrm{v})$ under humid fuel conditions may react rapidly with $\mathrm{H}_{2} \mathrm{O}$. This will cause the more volatile $\mathrm{NaOH}$ vapor species to be formed while releasing free HCl-gas according to the reaction:

$$
\mathrm{NaCl}(\mathrm{v})+\mathrm{H}_{2} \mathrm{O} \stackrel{\mathrm{K}_{\mathrm{T}}}{\longrightarrow} \mathrm{NaOH}(\mathrm{v})+\mathrm{HCl}(\mathrm{g})
$$

Thus, we have investigated the thermochemistry of this reaction at different temperatures for the amount of saturated NaCe vapor as it exists and reacts with humidified fuel gas and also is in equilibrium with condensed phase $\mathrm{NaC} \ell$ (s or $\ell$ ). We assume for the moment that saturated NaCl vapor is the only source of sodium or chloride species from the coal gasification process, and that it is usually in equilibrium with at least $20 \%$ humidity. The free energy data and changing equilibrium constants $\left(K_{T}\right)$ at different temperatures are illustrated in Table 8 and show that, in fact, a fair amount of free $\mathrm{HCl}$ gas and $\mathrm{NaOH}$ vapor can form in coal-gas. Sodium chloride salt itself rapidly condenses on pipe walls at lower temperatures but $9 \mathrm{ppm}$ saturated $\mathrm{NaCl}$ vapor remains at fuel cell temperature. The partial vapor pressure of saturated $\mathrm{NaOH}(\mathrm{g})$ that may exist in 1 atm. of inert gas in equilibrium with its condensed liquid state runs from 0.19 atm. partial pressure at $1127^{\circ} \mathrm{C}$ to $150 \mathrm{ppm}$ at $627^{\circ} \mathrm{C}$. Hence, condensing liquid $\mathrm{NaOH}$ is not a likely secondary reaction.

For comparison, the next to last column in Table 8 illustrates the saturated $\mathrm{NaOH}$ vapor pressure that could exist in fuel gas if there were a source of Iiquid $\mathrm{NaOH}$ present at all times. From Eq. 13, it is clear that a high $\mathrm{NaOH}$ vapor pressure would substantially suppress $H C l$ gas formation, although the relatively volatile $\mathrm{NaCl}(\mathrm{v})$ species that will remain up to its saturation value of 9 ppm, would still represent a considerable source of halide 
contaminant species for a fuel cell. An Arrhenius plot of the data (cf. Figure 5) clearly illustrates that when operating under the likely condition of NaCl-saturated vapor, about $10 \mathrm{ppm}$ halide species (as $\mathrm{NaCl}$ ) can still enter the carbonate fuel cell, even if the HCl form is suppressed to a very low level by the presence of excess $\mathrm{NaOH}$ vapor.

The above analysis is a worst case scenario. It assumes that when coal-gas cools from gasifier outlet to fuel cell inlet temperature without intermediate hot-gas cleanup, equilibrium amounts of liquid phase $\mathrm{NaCl}(l)$ condense out from the gas onto the pipe walls. The fuel is then always $9 \mathrm{ppm}$ NaCl-vapor-saturated at $650^{\circ} \mathrm{C}$. However, if the gas at fuel cell temperature contains only 1 ppm NaCl as a gaseous species (e.g., because of some type of intermediate hot-gas polishing), the amount of actual $\mathrm{HCl}(\mathrm{g})$ that would exist at $650^{\circ} \mathrm{C}$ is shown in the last column in Table 8 as less than $0.1 \mathrm{ppm}$.

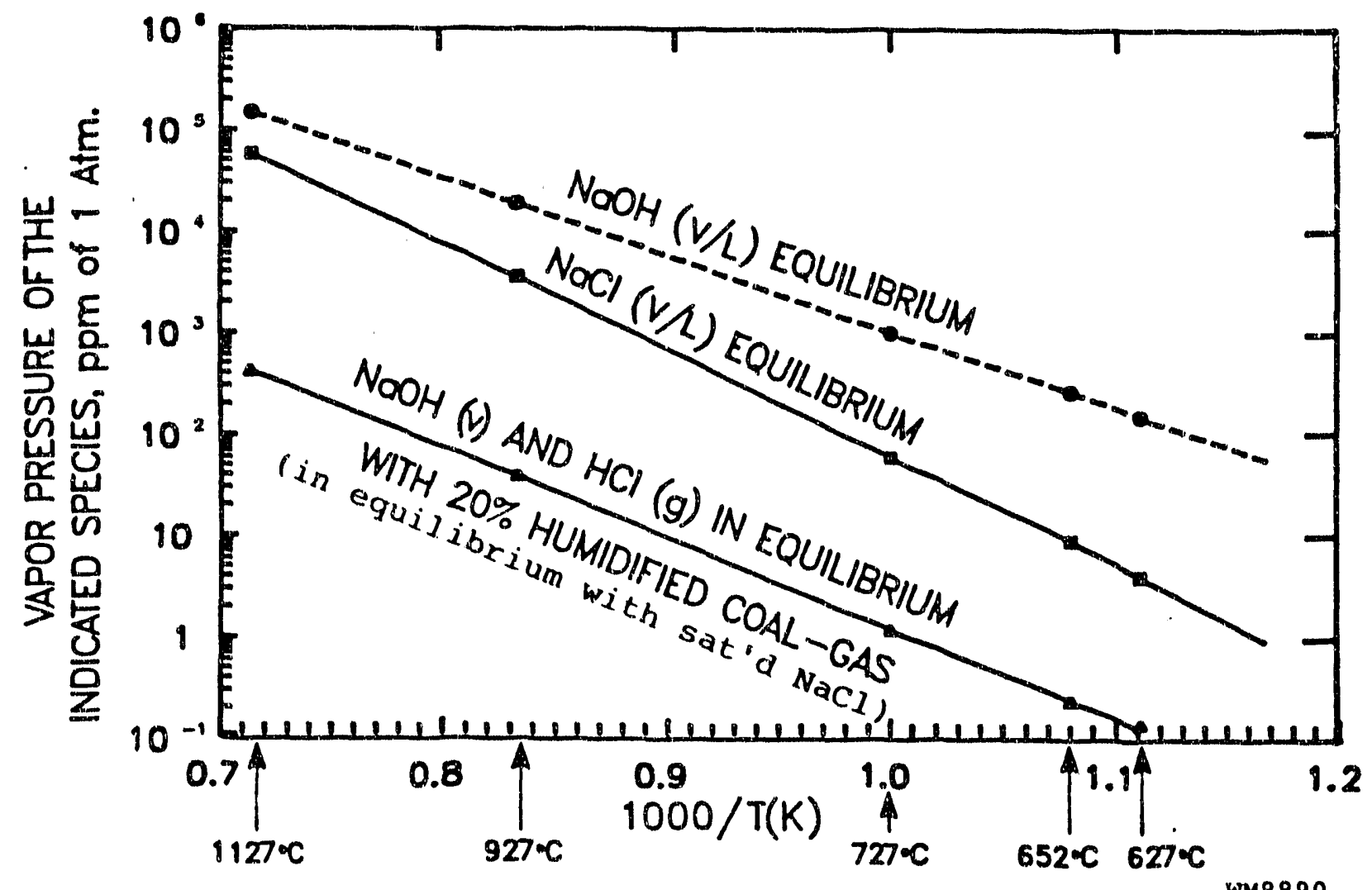

FIGURE 5 VAPOR PRESSURES OF SODIUM CHLORIDE SPECIES IN EQUILIBRIUM WITH 208 HUMIDIFIED COAL-GAS

Actual Concentrations of $\mathrm{HCl}(g)$ regardless of Hot-gas Clranup are Probably Low, but the NaCl(v) Species under Saturated Conditions at Fuel Cell Temperatures may remain as High as $10 \mathrm{ppm}$. 


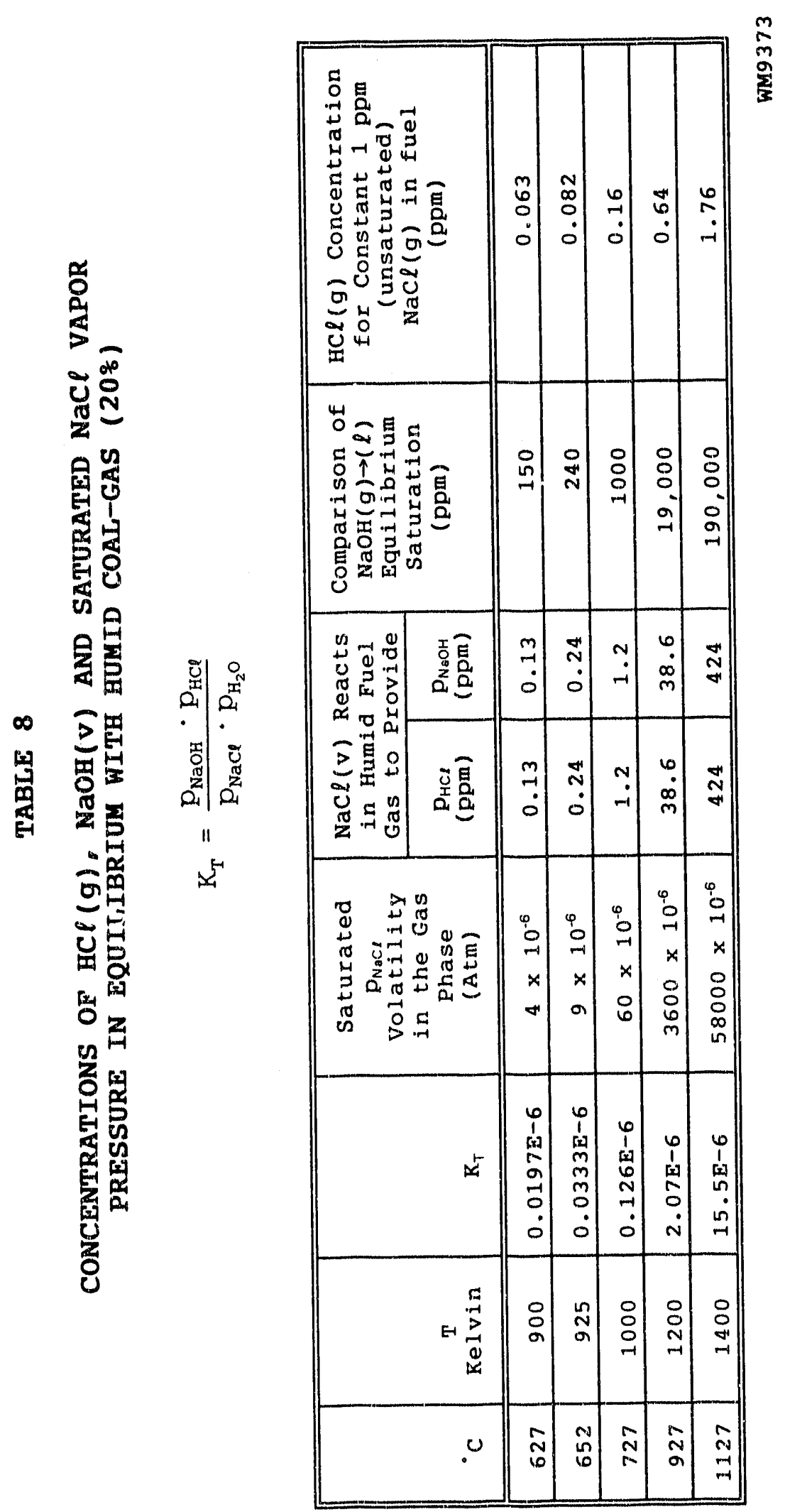




\subsubsection{Details of Combined $\mathrm{HCl} / \mathrm{H}_{2} \mathrm{~S}$ Equilibria}

Interactions between the two most important major coal-gas contaminant species, $\mathrm{HCl}$ and $\mathrm{H}_{2} \mathrm{~S}$, in the presence of nickel anode material and $L i / k$-carbonate melt were investigated in depth by SOLGASMIX thermochemical calculaticns, as illustrated in the Appendix Tables II.4/5/6. Interactions are presented first by parametrically varying $\mathrm{H}_{2} \mathrm{~S}$ in the presence of two constant $\mathrm{HCl}$ concentrations, and then by parametrically varying HCl levels in the presence of a constant (high) $\mathrm{H}_{2} \mathrm{~S}$ concentration. As previously noted, $\mathrm{NH}_{3}$ (the other major contaminant species) is carried along in all computations at its equilibrium concentration, but because of its inertness toward fuel cell materials, it is of no consequence to the outcome of these analyses.

Table II.4 (A,B,C) shows the effects of combining varying amounts of $\mathrm{H}_{2} \mathrm{~S}(50 \mathrm{ppb}$ to $20 \mathrm{ppm})$ with a very small (10 ppb) amount of $\mathrm{HCl}$. This value of $\mathrm{HCl}$ was chosen because it represents, presumably, a tolerable level of HCl contamination. The presence of sulfur is shown to have had no effect on the $\mathrm{C}^{-}$concentration in the melt. This may be readily ascertained by comparing 'column $\mathrm{HC} \ell-3^{\prime}$ in Table II. 1 (for HCl alone) with 'column $\mathrm{H}_{2} \mathrm{~S}-9$ ' of Table II.4. Chlorine and HCe species in the gas phase are not affected by each other either. This means that, although activities in the melt can influence each other somewhat, there is probably no gaseous compound formation of any $k$ ind between sulfur and chlorine at these temperatures. This is reasonable since there are also no thermodynamic data extant (in reducing environment at $650^{\circ} \mathrm{C}$ ) for such compounds as $\mathrm{SCl}_{2}$ or $\mathrm{SCl}_{4}$ which, however, do exist at room temperature.

Next, Table II.5 $(A, B, C)$ contains the results for the same levels of $\mathrm{H}_{2} \mathrm{~S}$ in the presence of a major amount (1 ppm) of HCl. As for this system's computations, which might have shown a greater influence due to much larger melt activity interactions, the presence of sulfur again has no effect on either melt or gas phase chlorine species. As before, the melt concentrations of $\mathrm{S}^{=}$and the much lower $\mathrm{SO}_{4}{ }^{2}$ level are each reduced only slightly from their values in earlier tables (cf. Appendix Tables II.2 and also II.4). This will be even more apparent in the results for the next system. 
Essentially the same predictable results are shown in Table II. 6 $(A, B \& C)$, where $\mathrm{HCl}$ is now varied parametrically from a very low ( 1 $\mathrm{ppb})$ concentration to the $3 \mathrm{ppm}$ level in the presence of a fairly high ( $1 \mathrm{ppm}) \mathrm{H}_{2} \mathrm{~S}$ concentration. The $\mathrm{HCl}$ levels used were the same as those presented in Table II. 1 for HCl by itself. The same 'activity' suppressing effect on sulfur compounds (mainly on $\mathrm{Li}_{2} \mathrm{~S}$ and $K_{2} S$ liquid species) and on the extremely low melt sulfate content due to increases in chloride concentration (Tables II. 4 and II.5), are also evident from the data in Table II.6 (B).

These activity changes result in a small, but steady, decrease in the actual $\mathrm{S}^{=}$and $\mathrm{SO}_{4}=$ ion concentrations in the melt, as shown in Table II. 6 (C). Even though this effect could slightly postpone the onset of electrode poisoning (due to the higher overpotentials caused by sulfur species adsorbed on the Ni-anode), so small a benefit would hardly offset the other very deleterious direct consequences of high chloride levels. For instance, column 4 of Table II.6, illustrates that even the presence of only $0.05 \mathrm{ppm} \mathrm{HCl}$ content in a coal-gas fuel. gives rise to the establishment of a possible equilibrium amount of $1.1 \mathrm{ppm}$ of $\mathrm{KCl}$ vapor in the gas phase (cf. Table 7). This is partly a consequence of the high $\mathrm{KCl}$ liquid activity in the melt phase (cf. Table II.6.B in the Appendix), which is approximately equivalent to the melt activity of $\mathrm{K}_{2} \mathrm{CO}_{3}(\ell)$ itself (viz. $\left.0.047 \mathrm{vs} .0 .069\right)$. And this is also reflected by the almost 1 mol: $\mathrm{Cl}^{-}$ion concentration of the overall anion content in the electrolyte.

\subsection{HYDROGEN SULFIDE}

It has been shown in a number of cell tests $(43,45)$ that slight performance decay as a result of short-term exposure to 1 ppm $\mathrm{H}_{2} \mathbf{S}$ can frequently be recovered using clean (non-sulfur) fuel gas and high potential or open-circuit operation. However, tolerance to the continuous and long-term presence of $\mathrm{H}_{2} \mathrm{~S}$ in fuel gas (for instance up to 40,000 hours) without any recovery periods is estimated to require a lower content of $\mathrm{H}_{2} \mathrm{~S}$, possibly $<0.5 \mathrm{ppm}$, which can be determined from the threshold concentration that 
begins to poison the cell when it is operated under different load and fuel conversion conditions. This will be further discussed in the final report concerned with modeling.

On the anode side, the plausible decay mechanism is probably chemisorption of a relatively stable, adsorbed sulfide compound (i.e., NiS ${ }_{x}$ ) on the active nickel anode surface:

$$
\mathrm{xS}=(\ell)+\mathrm{Ni}(\mathrm{C}) \longleftrightarrow \mathrm{NiS}_{\mathrm{x}} \text { (on } \mathrm{Ni} \text { surface) }+2 \mathrm{xe}^{-}
$$

This can already begin with $\mathrm{H}_{2} \mathrm{~S}$ at $1 \mathrm{ppm}$ in the gas phase when it dissolves to a considerable extent in the carbonate melt, forming almost 45 molar $\mathrm{ppm}$ of sulfide ion $\left(\mathrm{S}^{*}\right)$ in the carbonate anion content of the melt, as illustrated in Table $I I \cdot 2 \cdot C$ in Appendix A.

The values from this Appendix tabulation (parts A, B, and C) are summarized in Table 9 below. The thermodynamics indicate that, upon addition of $\mathrm{H}_{2} \mathrm{~S}$ in small stages to the fuel gas (going from 50 $\mathrm{ppb}$ to $20 \mathrm{ppm})$, the equilibrium sulfide content - as a molar ppm fraction of the liquid anion content of the electrolyte - increases at a proportional rate but with a $4 \mathrm{x}$ higher concentration in the melt than in the gas phase. Although still large, this represents a far lower solubility compared to hydrogen chloride. Thus, the consequences of $\mathrm{H}_{2} \mathrm{~S}$ contamination in fuel, as illustrated here, are clearly not as dramatic in changing the carbonate melt composition by sulfidation as compared to chloridation (cf. Tables 9 and 7).

on the other hand, sulfur as a contaminant behaves much more severely in directly polarizing the Ni-anode (cf. Eq. 14). The two reactions for $\mathrm{H}_{2} \mathrm{~S}$ (i.e., dissolution/ionization in the melt) and its possible further electrochemical oxidation are assumed to be as follows :

$$
\begin{aligned}
& \mathrm{H}_{2} \mathrm{~S}(\mathrm{~g})+\mathrm{CO}_{3}{ }^{\circ}(\ell) \longleftrightarrow \mathrm{S}^{=}(\ell)+\mathrm{H}_{2} \mathrm{O}(\mathrm{g})+\mathrm{CO}_{2}(\mathrm{~g}) \\
& \mathrm{S}=+2 \mathrm{CO}_{3}{ }^{\circ}+2 \mathrm{H}_{2} \mathrm{O} \longrightarrow \mathrm{SO}_{4}{ }^{\circ}+2 \mathrm{CO}_{2}+2 \mathrm{H}_{2}+4 \mathrm{e}^{-}
\end{aligned}
$$




\section{TABLE 9}

SUMMARY OF RELATED ANIONIC MELT CONCENTRATIONS AT $650^{\circ} \mathrm{C}$ IN EQUILIBRIUM WITH $\mathrm{H}_{2} \mathrm{~S}$ AND COS SPECIES IN THE GAS PHASE

\begin{tabular}{|c|c|c|c|c||}
\hline $\begin{array}{c}\mathrm{H}_{2} \mathrm{~S}(\mathrm{~g}) \\
\mathrm{ppm}\end{array}$ & $\begin{array}{c}\mathrm{S}^{=}(\ell) \\
\mathrm{mol}-\mathrm{ppm}\end{array}$ & $\begin{array}{c}\mathrm{CO}_{3}{ }^{2}(\ell) \\
\mathrm{mOI}_{8}\end{array}$ & $\begin{array}{c}\mathrm{SO}_{4}{ }^{\prime}(\ell) \\
\mathrm{mol}-\mathrm{ppm}\end{array}$ & $\begin{array}{c}\mathrm{COS}(\mathrm{g}) \\
\mathrm{ppm}\end{array}$ \\
\hline \hline 0.05 & 0.2 & 98.8 & $<<0.000001$ & 0.0009 \\
\hline 0.11 & 0.5 & 98.8 & 0.000001 & 0.002 \\
\hline 0.5 & 2.1 & 98.8 & 0.000007 & 0.009 \\
\hline $1^{*} .1$ & 4.5 & 98.8 & 0.000014 & 0.018 \\
\hline 2.0 & 8.3 & 98.8 & 0.000026 & 0.035 \\
\hline 5.0 & 20.7 & 98.8 & 0.000066 & 0.088 \\
\hline 10.7 & 44.5 & 98.8 & 0.00014 & 0.19 \\
\hline 15.0 & 64.1 & 98.8 & 0.0002 & 0.27 \\
\hline 20.0 & 83.0 & 98.8 & 0.00026 & 0.35 \\
\hline
\end{tabular}

WM9363

This table shows that the carbcnate anion fraction of electrolyte, at any point during $\mathrm{H}_{2} \mathrm{~S}$ dissolution, is not greatly affected even when high ppm levels of the gas begin to dissolve in the melt. Table 9 also shows that in the presence of the initially high hydrogen content of a nominal entry coal-gas composition, the 'equilibrium' oxidation of $\mathrm{S}^{=}$to $\mathrm{SO}_{4}{ }^{=}$anion is extremely small, a 5fold order of magnitude below the existing $\mathrm{H}_{2} \mathrm{~S}$ level. However, with high utilization of the gas toward the exit lowering the $\mathrm{H}_{2} / \mathrm{H}_{2} \mathrm{O}$ ratio, sulfate ion concentrations could become somewhat higher.

It can also be deduced from reactions [15] and [14] that, when both clean humidified fuel and greatly reduced load conditions with higher cell voltage are provided for a partially sulfide-poisoned fuel cell, it can substantially rid itself of its $S^{\prime \prime}-i$ on content by in-melt reversal. of these equilibrium reactions. Hence the cell can recover its decay due to polarization if, as has also been experimentally found in actual fuel cell operation, these equations represent readily reversible reactions. Besides the thermodynamically very small $\mathrm{SO}_{4}{ }^{2}$ concentration possible, it is likely that reaction [16] has a quite high activation barrier because of the 4-electron oxidation required for sulfate formation. 


\section{3 .1 Details of $\mathrm{H}_{2} \mathrm{~S}$ Equilibria}

In Appendix Table II.2 (A, B, and $C$ ), it is again noted that the subsections comprise: (A), the gaseous partial pressures; (B), the 'activities' of all possible liquid molecular compounds that can be present in the ideal melt solution as calculated by Conformal Ionic Solution Theory (CIST); and (C), the cation/anion fractions that these compounds represent upon complete ionization. Columns 1 through 9 show the corresponding quantities of the different species in the presence of various amount of $\mathrm{H}_{2} \mathrm{~S}(\mathrm{~g})$, ranging from $50 \mathrm{ppb}$ to $20 \mathrm{ppm}$. It is furtrermore noted toward the end of the c-table, that no stoichiometric equilibrium (liquid or solid) 'niclal sulfide' phase will form under the existing conditions with $\mathrm{H}_{2} \mathrm{~S}$ present at the levels indicated.

Since $\mathrm{Ni}_{3} \mathrm{~S}_{2}(\mathrm{C})$ has recently been found to be the most stable, pure, 'nickel sulfide' phase, many prior assertions that $\mathrm{Ni}_{3} \mathrm{~S}_{2}(\ell)$ at fuel cell temperatures is the most stable phase must now be discounted. The earlier observation was based on thermodynamic measurements by Rosenquist, which have now been criticized in the most recent JANAF compendium (14) from which the presently used free energy data were derivea. This consideration is not too important, however, since even the most stable solid nickel sulfide phase is not likely to exist in a carbonate fuel cell. For, if we consider the gaseous reaction leading to the most stable stoichiometric sulfide:

$$
\mathrm{H}_{2} \mathrm{~S}(\mathrm{~g})+3 \mathrm{Ni}(\mathrm{C}) \longrightarrow \mathrm{Ni}_{3} \mathrm{~S}_{2}(\mathrm{C})+2 \mathrm{H}_{2}(\mathrm{~g})
$$

and use the $\Delta G$ compilation of values for compound formation provided in appendix $B$, we find that the partial pressure of $\mathrm{H}_{2} \mathrm{~S}$ needed to be in equilibrium with $\mathrm{Ni}_{3} \mathrm{~S}_{2}$ is given by the expression:

$$
p_{H_{2} S}=0.002 \times p_{H_{2}}
$$

At a nominal $0.36 \mathrm{~atm}$. of $\mathrm{H}_{2}$ pressure, we see that $7.2 \times 10^{-4} \mathrm{~atm}$. or $720 \mathrm{ppm}$ of $\mathrm{H}_{2} \mathrm{~S}(\mathrm{~g})$ would be required to form $\mathrm{Ni}_{3} \mathrm{~S}_{2}(\mathrm{c})$, whether we consider the formation of this compound from a direct gas equilibrium (Eq. 17 ) or via an electrochemicai reaction with dissolved s"-ion, such as may be written: 


$$
2 \mathrm{~s}=+3 \mathrm{Ni}(\mathrm{C}) \longleftrightarrow \mathrm{Ni}_{3} \mathrm{~S}_{2}(\mathrm{C})+4 e^{-}
$$

This latter equation provides the opportunity (as in the case of $\mathrm{NiCl}_{2}$ ) to analyze the overpotential at which $\mathrm{Ni}_{3} \mathrm{~S}_{2}$ formation could become favored. At 1 ppm of $\mathrm{H}_{2} \mathrm{~S}(\mathrm{~g})$ and nominal $0.36 \mathrm{~atm} . \mathrm{H}_{2}$, the $\Delta G$ of reaction [17] is equal to $100.94 \mathrm{~kJ} / \mathrm{mol}$. This means that an oxidizing overpotential of $+262 \mathrm{mV}$ will have to be applied relative to the rominal operating potential of the anode before electrochemical formation of $\mathrm{Ni}_{3} \mathrm{~S}_{2}(\mathrm{c})$ can occur via reaction [1.9]. Because this value is in the range of anode polarization under load which can occur during high current density operation, the possibility of bulk $\mathrm{Ni}_{3} \mathrm{~S}_{2}(\mathrm{c})$ formation cannot be entirely discounted if, at the same time, very high fuel utilization also occurs.

on the other hand, prior work with $\mathrm{H}_{2} \mathrm{~S}$ has established that mere chemisorption of $\mathrm{S}$-ion on a $\mathrm{Ni}$-anode cirectly or by an electrochemical process (as shown in Eq. 14) can lead to considerable, and immediate, performance losses. The assumed reaction ( $\mathrm{Eq}$. 15) was calculated to occur when the anode potential (relative to a $2: 1 \quad \mathrm{CO}_{2} / \mathrm{O}_{2}$ reference electrode) became more positive than the potential given by the following expression:

$$
E\left(N i S_{x}\right)=a_{3}-(\mathrm{RT} / 4 \mathrm{~F}) \ln \mathrm{P}+(\mathrm{RT} / 2 \mathrm{~F}) \ln \left(\mathrm{X}_{\mathrm{H}_{2} \mathrm{O}} \mathrm{X}_{\mathrm{CO}_{2}} / \mathrm{X}_{\mathrm{H}_{2} \mathrm{~S}}\right)
$$

where $a_{s}$ is an 'empirical' threshold Nernst constant, evaluated by $1 / 2$-cell testing to be -1.393 Volt. With this Nernst value, it was found that $E q .20$ could lead to modeling predictions of levels of performance loss that were in reasonable agreement with those found in actual fuel cell tests (19). The other terms in Eq. 20 arise in part from the $\mathrm{H}_{2} \mathrm{~S} / \mathrm{S}^{-}$melt equilibrium shown in Eq. 15, and partly from the pressure dependence of the $2: 1 \quad \mathrm{CO}_{2} / \mathrm{O}_{2}$ reference electrode potential.

\subsubsection{Details of $\mathrm{H}_{2} \mathrm{~S} / \mathrm{COS}$ Equilibrium}

Initial interaction of $\mathrm{H}_{2} \mathrm{~S}$ just in the gas phase with other major fuel gas components such as $\mathrm{CO}_{2}(\mathrm{~g})$ or $\mathrm{CO}(\mathrm{g})$ can lead to equilibrium vapor formation of a carbonyl sulfide species, $\operatorname{CoS}(g)$, as was already shown in Table 9 . This is not believed to be a 
separately reacting species because kinetically, at nominal fuel cell temperatures, the following reaction can be considered to occur so rapidly as to be in continuous equilibrium with the various gases present:

$$
\mathrm{H}_{2} \mathrm{~S}(\mathrm{~g})+\mathrm{CO}_{2}(\mathrm{~g}) \stackrel{\mathrm{K}_{\mathrm{T}}}{\longrightarrow} \mathrm{COS}(\mathrm{g})+\mathrm{H}_{2} \mathrm{O}(\mathrm{g})
$$

which at $650^{\circ} \mathrm{C}$ has an equilibrium constant:

$$
\mathrm{K}_{\mathrm{T}}=\exp \left[-\Delta \mathrm{G}^{\circ} / \mathrm{RT}\right]=0.016
$$

and therefore, the COS concentration (or rather the $\operatorname{COS} / \mathrm{H}_{2} \mathrm{~S}$ ratio) as a function $\mathrm{f}\left(\mathrm{T}, \mathrm{CO}_{2} / \mathrm{H}_{2} \mathrm{O}\right)$, can be written:

$$
\mathrm{p}_{\mathrm{COS}} / \mathrm{p}_{\mathrm{H}_{2} \mathrm{~S}}=0.016 \cdot \mathrm{p}_{\mathrm{CO}_{2}} / \mathrm{p}_{\mathrm{H}_{2} \mathrm{O}}
$$

This cos reaction, which is homologous with the equally rapidly equilibrating watergas shift reaction normally used to calculate $\mathrm{H}_{2} / \mathrm{CO}_{2}$ or $\mathrm{H}_{2} \mathrm{O} / \mathrm{CO}$ ratios in fuel, is similarly not a pressure sensitive reaction (i.e., it is an equal-gas-volume metathesis). For most nominal coal-gas compositions with $\mathrm{CO}_{2} / \mathrm{H}_{2} \mathrm{O}$ ratios near unity, the partial pressure of equilibrium cos content in fuel, from Eq. 23, is found to be always less than $\sim 2 \%$ of a given $\mathrm{H}_{2} \mathrm{~S}$ contaminant level, or $18.8 \mathrm{ppb}$. for a $1.07 \mathrm{ppm} \mathrm{H}_{2} \mathrm{~S}$ gas concentration, as has been shown in every SOLGASMIX tabulation with sulfur present. Clearly, at hot-gas cleanup temperatures, the cos will also proportionately and rapidly decrease in concentration while $\mathrm{H}_{2} \mathrm{~S}$ is being removed.

\subsection{HYDROGEN SELENIDE}

Although its maximum occurrence in coal-gas has not been found to be very high (i.e., $\sim 5 \mathrm{ppm}), \mathrm{H}_{2} \mathrm{Se}(\mathrm{g})$ can be of concern, since it appears to be more reactive than $\mathrm{H}_{2} \mathrm{~S}$ with respect to nickel. Fortunately, in the same way that $\mathrm{H}_{2} \mathrm{~S}$ interacts chemically with Fe and $\mathrm{zn}$ compounds (e.g., in a hot-gas cleanup system), hydrogen selenide also forms very stable, condensed phase $z$ nse in a reducing coal-gas environment at $650^{\circ} \mathrm{C}$, as shown by the very low $\mathrm{ZnSe}(\mathrm{g})$ vapor pressure $\left(1.4 \times 10^{-14}\right.$ atm. $)$ in Appendix A, Table I.4. This bodes well for hot-gas cleanup systems utilizing 2 no or $\mathrm{ZnFe}_{2} \mathrm{O}_{4}$ because these compounds as with sulfur, will be able to remove 
selenium down to very small trace amounts. This is necessary, as cell tests have generally shown (viz. Cell 7-215) that performance degradation due to $\mathrm{H}_{2} \mathrm{Se}(\mathrm{e} . \mathrm{g}$. , at 1 ppm concentration) can be rapid and fairly large. However, the effects are also recoverable when contamination is not continued too long.

Thus, on the anode side (similar to $\mathrm{H}_{2} \mathrm{~S}$ ), the most plausible electrode polarization mechanism is again considered to be due to chemisorption and formation of a relatively stable, hypostoichiometric selenide compound (e.g., $\mathrm{NiSe}_{\mathrm{x}}$ for $\mathrm{x}<1$ ) on the nickel electrode surface:

$$
\mathrm{xSe}=(\ell)+\mathrm{Ni}(\mathrm{C}) \longleftrightarrow \mathrm{NiSe}_{\mathrm{x}}+2 \mathrm{xe}^{-}
$$

This can probably begin at less than $1 \mathrm{ppm} \mathrm{H}_{2}$ Se concentration in the gas phase after the vapor has sufficiently dissolved in the molten carbonate electrolyte. Formation of about 10 molar ppm selenide ion ( $\mathrm{Se}^{=}$) in the carbonate anion content of the electrolyte is illustrated in Appendix A in Table II.3.C.

When summarizing values from this Appendix table, as shown in Table 10 below, it is seen that thermodynamically, upon addition of $\mathrm{H}_{2} \mathrm{Se}$ in small stages to fuel gas going from $\sim 84 \mathrm{ppb}$ to $\sim 3.4 \mathrm{ppm}$, the equilibrium selenide fraction - as a molar ppm fraction of the liquid 'anion' content in the electrolyte - increases at a proportional rate but with $10 \mathrm{x}$ higher concentration in the melt than in the gas phase. This shows a somewhat greater solubility of selenide ion over sulfide ion for equivalent equilibrium gas concentrations and consequently shows a greater concentrating effect for selenium over sulfur in the electrolyte.

Similar reactions, previously proposed in Eqs. 14 and 15, are assumed to occur in the case of selenium contamination. Again, in Table 10 it is shown that the carbonate anion content of the electrolyte is not greatly affected by selenium contamination. Data on formation of cose are not readily available because this gas, although its existence appears reasonable, has never been thermodynamically investigated as far as we were able to determine. 
TABLE 10

\section{SUMMARY OF EQUILIBRIUM SELENIDE AND CARBONATE ANION SPECIES IN CARBONATE ELECTROLYTE @ $650^{\circ} \mathrm{C}$}

\begin{tabular}{|c|c|c|}
\hline $\begin{array}{c}\mathrm{H}_{2} \mathrm{Se}(\mathrm{g}) \\
\mathrm{ppm}\end{array}$ & $\begin{array}{c}\mathrm{Se}^{=}(\ell) \\
\mathrm{mol}-\mathrm{ppm}\end{array}$ & $\begin{array}{c}\mathrm{CO}_{3}{ }^{=}(\ell) \\
\mathrm{mol}\end{array}$ \\
\hline 0.084 & 0.8 & 98.8 \\
\hline 0.42 & 4.8 & 98.8 \\
\hline 0.84 & 8.0 & 98.8 \\
\hline 1.7 & 16 & 98.8 \\
\hline 2.5 & 24 & 98.8 \\
\hline 3.4 & 32 & 98.8 \\
\hline
\end{tabular}

WM9364

other selenium contaminant interactions not with fuel or fuel cell components are known, for instance between se and cadmium or lead, but this will be considered later when the metallic species are discussed. The initially high $\mathrm{H}_{2}$-content in a fuel can presumably prevent formation of the selenite ion $\left(\mathrm{SeO}_{3}{ }^{\prime}\right)$, but it should be considered because this species could, under high fuel gas utilization, also increase its concentration toward the cell exit. And at that point it might form some highly stable metallic selenites such as $\mathrm{CdSeO}_{3}(\ell)$.

Finally, as with sulfide poisoning we can also deduced that, if rapid equilibration of $\mathrm{NiSe}_{x}$ surface species occurs with the $\mathrm{Se}^{-}-$ ion content, then with clean fuel and greatly reduced load conditions a partially selenium-poisoned cell will also be able to rid itself of selenium and recover performance. This has, in fact, been observed in a number of single and combined contaminant benchscale tests.

\subsubsection{Details of $\mathrm{H}_{2}$ Se Equilibria}

Looking in greater detail at Table II. $3(A, B, C)$, we note in columns 1 through 6 that with $\mathrm{H}_{2} \mathrm{Se}(\mathrm{g})$ concentrations between about 0.1 to $3.4 \mathrm{ppm}$, there is no danger of pure condensed nickel selenide forming. However, to quantify the concentration of 
gaseous $\mathrm{H}_{2} \mathrm{Se}$ that could lead to direct, solid $\mathrm{NiSe}(\mathrm{c})$ formation in the fuel cell, consider the reaction:

$$
\mathrm{H}_{2} \mathrm{Se}(\mathrm{g})+\mathrm{Ni}(\mathrm{c}) \longleftrightarrow \mathrm{NiSe}(\mathrm{c})+\mathrm{H}_{2}(\mathrm{~g})
$$

By way of the free energies of these species, an equilibrium constant expression can also be derived for the $\mathrm{H}_{2} \mathrm{Se}(\mathrm{g})$ partial pressure in equilibrium with condensed NiSe(c):

$$
\mathrm{p}_{\mathrm{H}_{2} \mathrm{Se}}=\mathrm{p}_{\mathrm{H}_{2}} \times 1.17 \times 10^{-4}
$$

At a nominal 0.36 atm. of $\mathrm{H}_{2}$, it is found that if partial pressures of $\mathrm{H}_{2} \mathrm{Se}$ ever $\mathrm{rise}$ above $4.2 \times 10^{-5} \mathrm{~atm}$. (or $42 \mathrm{ppm}$ in the gas phase which is higher than considered in any of the SOLGASMIX. computations), then formation of a solid NiSe phase is possible. But at lower $\mathrm{H}_{2}(\mathrm{~g})$ pressures such as 0.036 atm. when $290 \%$ fuel conversion has occurred, NiSe(s) could form toward the fuel exit location with only as little as $4.2 \mathrm{ppm} \mathrm{H}_{2} \mathrm{Se}$ in the gas.

By again considering the equivalent electrochemical reaction in the melt phase:

$$
\mathrm{Se}^{=}(\ell)+\mathrm{Ni}(\mathrm{c}) \longrightarrow \mathrm{NiSe}(\mathrm{s})+2 e^{-}
$$

we can deduce the value of overpotential required (i.e., more positive than the cell's normal anode open-circuit potential), to form stoichiometric $\mathrm{NiSe}$ on the anode surface. The $\Delta G$ for reaction 25 can be written as:

$$
\Delta G=-69.45 \mathrm{~kJ}+\operatorname{RT} \ln \mathrm{P}_{\mathrm{H}_{2}} / \mathrm{P}_{\mathrm{H}_{2} \mathrm{Se}}
$$

which equals $23.442 \mathrm{~kJ}$ when 0.18 atm. of $\mathrm{H}_{2}$ is present (e.g.' at the exit when $\sim 50 \%$ fuel is utilized) with 1 ppm of $\mathrm{H}_{2} \mathrm{Se}(\mathrm{g})$. This Gibbs free energy aifference is equivalent to a polarizing (or driving) potential difference for reaction 27 equal to $121 \mathrm{mV}$ in accordance with the $1 / 2$-cell potential relationship $\Delta G=n F \Delta E$. Hence, for formation of $\mathrm{NiSe}$, the anode needs to be polarized by becoming "only" $121 \mathrm{mV}$ more positive at any location where it is in competition with the local fuel cell hydrogen oxidation reaction. Note that this overvoltage is a considerably smaller value than was found for the case of bulk $\mathrm{Ni}_{3} \mathrm{~S}_{2}$ formation, which clearly 
illustrates the generally greater reactivity of selenide over sulfide ions in the electrolyte.

utilizing the modeling study made earlier for incipient (i.e., partial poisoning) effects due to sulfur (19), where an empirical threshold potential $\alpha_{s}=-1.393$ Volt was measured, one may also make a thermodynamic estimate of this value for selenium. Thus an equivalent selenium threshold potential may be calculated by comparison of the following anode $1 / 2$-cell reactions for the two contaminants:

$$
\begin{gathered}
\mathrm{H}_{2} \mathrm{Se}+\mathrm{CO}_{3}{ }^{-}+\mathrm{Ni} \\
\mathrm{H}_{2} \mathrm{~S}+\mathrm{CO}_{3}{ }^{2}+1.5 \mathrm{NiSe}(\mathrm{C})+\mathrm{H}_{2} \mathrm{O}+\mathrm{CO}_{2}+2 \mathrm{e}^{-} \\
\longrightarrow 0.5 \mathrm{Ni}_{3} \mathrm{~S}_{2}(\mathrm{C})+\mathrm{H}_{2} \mathrm{O}+\mathrm{CO}_{2}+2 e^{-}
\end{gathered}
$$

The most stable forms of the different $\mathrm{Ni}$-compounds were used since we have no other thermodynamic information for relating the hypostoichiometric surface compounds $\mathrm{NiS}_{\mathbf{x}}$ to $\mathrm{NiSe}_{\mathrm{x}}$; the assumption was made that a parallel difference in the free energies of reaction exists. The potential difference, in terms of the $\Delta G$ between these reactions, written as:

$$
\mathrm{H}_{2} \mathrm{Se}(\mathrm{g})+1 / 2 \mathrm{Ni}_{3} \mathrm{~S}_{2}(\mathrm{c}) \longleftrightarrow \mathrm{NiSe}(\mathrm{c})+\mathrm{H}_{2} \mathrm{~S}(\mathrm{~g})+1 / 2 \mathrm{Ni}(\mathrm{c})
$$

was then employed to obtain an equivalent "selenation" threshold potential from the measured "sulfation" potential. In other words, the two poisoning potentials were assumed to be related by the expression:

$$
a_{S e}=a_{B}+\Delta G / 2 F
$$

Thus, by also comparing and adjusting the threshold potential for partial poisoning during a recovery condition while operating on $0.15 \mathrm{ppm} \mathrm{H}_{2} \mathrm{Se}$ - as measured in the selenium contaminant cell, No. 7-215 - the threshold selenation value of $a_{\mathrm{Se}}=-1.474$ Volt was obtained. Using this empirical threshold constant, it is now possible to calculate other Nernst polarization potentials, from the following equation:

$$
E_{\left(\mathrm{NiS}_{\mathrm{x}}\right)}=a_{\mathrm{Se}}-\frac{\mathrm{RT}}{2 \mathrm{~F}} \ln \frac{\mathrm{X}_{\mathrm{H}_{2} \mathrm{Se}}}{\mathrm{X}_{\mathrm{H}_{2} \mathrm{O}} \cdot \mathrm{X}_{\mathrm{CO}_{2}}}
$$


Given the limited performance data on selenium, this value is the best estimate for $a_{\text {se }}$ that can presently be made. It appears reasonable, however, in comparison to the sulfation threshold potential of $-1.393 \mathrm{~V}$. Cell voltages were modeled and calculated for a number of other poisoning levels obtained during operation of Cell 7-215, and these (i.e., $V_{c}$ ) compare well with the actually measured average values $\left(V_{\bar{\alpha}}\right)$ as shown in Table 11 .

TABLE 11

ACTUAL CELL VOLTAGES, $V_{\tilde{a}}$, VERSUS CALCULATED VOLTAGES, $V_{c}$ ON FUEL CONTAMINATED WITH $\mathrm{H}_{2}$ Se AT $160 \mathrm{~mA} / \mathrm{cm}^{2}$ WITH 75\%/508 FUEL/OXIDANT UTILIZATIONS

(Anode Electrolyte Fill Fractions, $\epsilon$, used in Calculating $\mathrm{V}_{\mathrm{c}}$ are shown at the Indicated Life Times)

\begin{tabular}{|c|c|c|c|c|}
\hline $\mathrm{ppm}$ of $\mathrm{H}_{2} \mathrm{Se}$ & $\mathrm{V}_{\bar{\alpha}},(\mathrm{mV})$ & $\mathrm{V}_{c^{\prime}}(\mathrm{mV})$ & $\epsilon$ & $\begin{array}{c}\text { Operating } \\
\text { Time }\end{array}$ \\
\hline 1.2 & 650 & 649 & 0.41 & 1000 hours \\
\hline 0.6 & 652 & 646 & 0.39 & 1175 hours \\
\hline 0.15 & 688 & 688 & 0.36 & 1425 hours \\
\hline 0.9 & 632 & 629 & 0.31 & 1775 hours \\
\hline 1.4 & 599 & 604 & 0.25 & 2200 hours \\
\hline
\end{tabular}

WM9365

Additional discussion with regard to these poisoning parameters will be offered when the complete modeling work is presented. Suffice it to observe here that the apparently more severe poisoning action due to selenium, as compared to sulfur at equivalent gas concentration, is also predictable from the larger concentrating effect of the respective anions in carbonate melt. This became evident quite early from the SOLGASMIX computations illustrated in Tables 9 and 10 . Since both chemisorbed $\mathrm{NiSe}_{\boldsymbol{x}}$ or the bulk compound NiSe(s) are so close to being formed even at fairly low ppm levels of $\mathrm{H}_{2} \mathrm{Se}$ and with only slight electrochemical encouragement, it appears that Nise surface species are more readily formed than the $\mathrm{Ni}_{3} \mathrm{~S}_{2}$ species. This possibility clearly deserves additional experimental confirmation by both chemical analysis and further empirical evidence. 


\subsection{ARSENIC}

Volatile arsenic (As) compounds, similar to the case for selenjum, do not seem to occur at very high concentrations in raw coal-gas (e.g., $10 \mathrm{ppm}$ ); however, arsenic species, at the high temperatures of a fuel cell, have a much more deleterious and permanent effect on performance than selenium. There appears little possibility of recovery once arsenic poisoning has taken place. Similar to other metalloid species such as $\mathrm{S}$ and $\mathrm{Se}$, the primary arsenic species $\left(\mathrm{AsH}_{3}\right.$ and also $\left.\mathrm{As}_{2}\right)$ in dry reducing environment tend to form the relatively stable zinc compound $\mathrm{Zn}_{3} A s_{2}$, which is a solid of very low volatility. This is, of course, a useful property when considering hot-gas cleanup systems utilizing $\mathrm{zno}$ or $\mathrm{ZnFe}_{2} \mathrm{O}_{4}$ sorbent material.

The following reaction is assumed to occur when arsenic is removed by zinc type sorbents:

$$
3 \mathrm{ZnO}(\mathrm{s})+2 \mathrm{AsH}_{3}(\mathrm{~g}) \longmapsto \mathrm{Zn}_{3} \mathrm{As}_{2}(\mathrm{~s})+3 \mathrm{H}_{2} \mathrm{O}(\mathrm{g})
$$

From this reaction, the thermodynamically calculated equilibrium constant at $650^{\circ} \mathrm{C}$ can be derived as follows:

$$
\mathrm{K}_{650}=\exp _{10}[95,850 /(2.303 \times 8.317 \times 923)]=2.64 \times 10^{5}
$$

which shows that the $\mathrm{AsH}_{3}$ (gaseous) contaminant level can only become very low if the gas stream is quite dry. This is because the condensed $\mathrm{Zn}_{3} \mathrm{As}_{2}(\mathrm{~s})$ is in equilibrium with $\mathrm{H}_{2} \mathrm{O}$ to the third power, and thus remains in the presence of a fair amount of gaseous $\mathrm{AsH}_{3}$ concentration unless water is removed. This $\mathrm{AsH}_{3}$ level can be calculated as:

$$
\mathrm{p}_{\mathrm{AsH}_{3}}=\left[\mathrm{p}_{\mathrm{H}_{2} \mathrm{O}}^{3} / 2 \cdot 64 \mathrm{E}+5\right]^{1 / 2}
$$

which still amounts to $\sim 2 \mathrm{ppm}$ of arsine, even if the fuel contains less than $1 \%$ humidity. Thus, one would predict that arsenic species will normally not be sufficiently removed by means of $z$ inc sorbents, but this is to be further verified.

At any rate, the plausible decay mechanisin on the anode side of the fuel cell is considered to be the formation of one or more monolayers of stable NiAs(c) alloy when the nickel surface becomes 
poisoned either directly or by the presence of $\mathrm{As}^{3+}$ cations in the melt. This latter process is thought to occur by a two-step mechanism: an oxidative dissolution of gaseous arsenic species at the gas/melt interface, as in the case of arsenic vapor:

$$
\mathrm{AS}_{2}(\mathrm{~V})+3 \mathrm{H}_{2} \mathrm{O}+3 \mathrm{CO}_{2} \longrightarrow 2 \mathrm{AS}^{3+}+3 \mathrm{CO}_{3}^{2}+3 \mathrm{H}_{2}
$$

and a reductive reaction of the $\mathrm{As}^{3+}$ cations when these combine with the Ni-anode surface:

$$
2 \mathrm{Ni}(\mathrm{C})+2 \mathrm{As}^{3+}+3 \mathrm{H}_{2}+3 \mathrm{CO}_{3}{ }^{=} \longrightarrow 2 \mathrm{NiAs}(\mathrm{C})+3 \mathrm{H}_{2} \mathrm{O}+3 \mathrm{CO}_{2}
$$

For thermochemical equilibrium purposes, these successive reactions can be written as one process:

$$
2 \mathrm{Ni}(\mathrm{C})+\mathrm{As}_{2}(\mathrm{~V}) \longleftrightarrow 2 \mathrm{NiAs}(\mathrm{C})
$$

but the kinetics may not be as simple or direct.

Arsenic, as illustrated in Table 4, lies on the periodic table boundary between the metallic and the metalloid region and has certain characteristics of both classes of elements. With metals such as $\mathrm{Zn}$ and $\mathrm{Cd}$, arsenic forms stable metal/metalloid compounds and high-temperature liquids representing 3-valent, stoichiometric arsenide salts (i.e., $\mathrm{Zn}_{3} \mathrm{As}_{2}$ and $\mathrm{Cd}_{3} \mathrm{As}_{2}$ ), while with $\mathrm{Ni}$ it forms a large range of metallic alloy solutions, among which one compusition, NiAs(c), stands out as a crystalline, inter-metallic compound with stable, long-range order. On the other hand, even though As has metalloid properties, arsenic still cannot exist as an anion in aqueous solution (i.e., as the $\mathrm{As}^{3-}$ anion), but like many amphoteric metals, it will commonly form the oxyanions, $\mathrm{AsO}_{3} \equiv$ and $\mathrm{ASO}_{4} \equiv$, which in mildly alkaline solution will be in equilibrium with $\mathrm{As}^{3+}$ cations [53].

Due to insufficient thermodynamic data for many condensed phase arsenic salts [e.g., $\left.\mathrm{As}_{2}\left(\mathrm{CO}_{3}\right)_{3}\right]$ in the form of high temperature, liquid or solid phases, it has so far been impossible to provide the CIST treatment for arsenic ion formation in a carbonate melt. On the other hand, thermodynamic data have been found for some high-temperature, condensed arsenic phases such as $\mathrm{ASCl}_{3}, \mathrm{AS}_{2} \mathrm{~S}_{3}$, and $\mathrm{AS}_{2} \mathrm{Se}_{3}$, showing again that there are fairly strong 
metallic properties associated with arsenic. As mentioned, however, this knowledge of the contaminant interactions among themselves is not nearly as important as the free energy data for the main high temperature arsenic salt of carbonate in the form of a pure condensed phase. This must be available to compute a CIST description of arsenic cation melt activity.

With regard to the contaminant/electrode interaction, however, good thermodynamic data are available for the stable NiAs-alloy as an intermeta?lic compound. This can therefore provide the data for formation of a condensed surface alloy, NiAs(c), which can then be evaluated by thermochemical calculation. Therefore, in lieu of including a liquid melt phase to provide a complete treatment for arsenic in the overall system, the discussion will first concentrate on the possible gaseous species of atomic arsenic as shown in Tables $I \cdot 6$ and I. 7 of Appendix A. The presentation will then concentrate mainly on the solid phase, NiAs(c), in the presence of a large amount of $\mathrm{Ni}(\mathrm{s})$ in the system. The latter results are presented as a special case in Table I. 8 of Appendix A.

Tables I. 6 and $I \cdot 7$ present, among the various interactions, results for just fuel gas mixtures containing the gaseous trace element arsenic in its different forms. The results in Table I.6 are for a system containing 1 ppm total atomic arsenic in the presence of varying amounts of $\mathrm{HCl}, \mathrm{H}_{2} \mathrm{~S}$, and $\mathrm{H}_{2} \mathrm{Se}$. Column $\varnothing$, however, contains the results for the gas mixture free of any $\mathrm{Cl}$, $\mathrm{S}$, or Se. From this column we see that the total atomic concentration of vapor phase As is primarily partitioned among four species, as summarized in Table 12 in the order of their decreasing concentrations. These results suggested that the form in which gaseous arsenjc species may appear in fuel is quite complex. Hence, a further computation was done to explore a wider range of total atomic As concentrations, as illustrated in Table $I \cdot 7$ of Appendix A.

SOLGASMIX computations at 1 ppm, $0.1 \mathrm{ppm}$ and 5 ppb total arsenic are summarized in Table 12. It is clear from these calculations that the type of arsenic species in the gas phase varies considerably with total atomic As concentration. At the lowest level, $\mathrm{AsH}_{3}(\mathrm{~g})$ (arsine) is the dominant molecular species in 
terms of molecular partial pressure, and almost in terms of total atomic As content. This is because at low As levels, entropic effects favor diatomic compound formation, and the high $\mathrm{H}_{2}$ partial pressure favors arsine over $\mathrm{As}_{2}$. With increasing As concentration, the arsine $\left(\mathrm{AsH}_{3}\right)$ level rises only slowly while the balance of the arsenic goes into diatomic and tetratomic species.

\section{TABLE 12}

\section{DISTRIBUTION OF GASEOUS ARSENIC MOLECULAR SPECIES}

It is Noted That the Equilibrium Ratio of the Forms of As-species in Gaseous Fuel Varies Considerably With Total. Atomic As-Concentration

\begin{tabular}{||c|c|c|c|c|c|c||}
\hline As-species & Mo 1. ppm & Atom ppm & Mo 1. ppm & Atom ppm & Mo 1.ppb & Atom ppb \\
\hline \hline $\mathrm{As}_{2}$ & 0.436 & 0.872 & 0.043 & 0.086 & 1.39 & 2.78 \\
$\mathrm{AsH}_{3}$ & 0.039 & 0.039 & 0.012 & 0.012 & 2.21 & 2.21 \\
$\mathrm{As}_{4}$ & 0.022 & 0.088 & $0.22 \times 10^{-3}$ & 0.0009 & $0.22 \times 10^{-3}$ & 0.0009 \\
$\mathrm{As}_{3}$ & $28 \times 10^{-6}$ & - & $0.87 \times 10^{-6}$ & - & - & - \\
\hline Total As & & $\sim 1 \mathrm{ppm}$ & & $\sim 0.1$ & & $\sim 5 \mathrm{ppb}$ \\
\hline
\end{tabular}

WM9366

Table $I \cdot 7$ in Appendix A also shows that, above a total atomic arsenic level of $100 \mathrm{ppm}$, the $\mathrm{As}_{4}(\mathrm{~V})$ species becomes dominant due to its greater intrinsic stability. Although greater than $100 \mathrm{ppm}$ arsenic is not an important occurrence in coal-gas, this final observation regarding the stability of arsenic species is of interest: e.g., earlier we had estimated that $\mathrm{AsH}_{3}$, the trace species utilized during our original arsenic cell testing (9), decomposes and deposits arsenic above $-300^{\circ} \mathrm{C}$ while the gas is preheated before entering the fuel cell. Then, it was feared, there would be a problem in maintaining sufficiently high arsenic contaminant concentration in the fuel cell because of sublimation of solid arsenic in the cell's entry tube, in the temperature interval from $300^{\circ}$ to $650^{\circ} \mathrm{C}$. However, it now appears that more than enough arsenic has been present in these original tests (i.e., 
in Cell 7-103) and that, since considerable arsenic was later also found in the melt, gaseous $\mathrm{AsH}_{3}$ and $\mathrm{As}_{2}(v)$ were present inside the cell.

In connection with arsenic interactions with nickel inside a fuel cell, calculation runs were performed as shown in Table $I \cdot 8$ in Appendix A. The computations were performed for four different levels of total As content in the presence of a solid phase of nickel; viz. for concentrations of $1,3,5$ and 5.16 part per billion (pp'), as shown in columns As-0, -1, $-2,-3$, respectively. The gas phase arsenic species are dominated by three forms, $\mathrm{As}_{2}$, $\mathrm{AsH}_{3}$, and $\mathrm{As}_{4}$. All of these are expected to dissolve readily in the melt by oxidative dissolution and ionization, thereby providing a source of $\mathrm{As}^{3+}$ ions in the melt. From the result in column As-2 for a total atomic concentration of $5 \mathrm{ppb}$ gaseous arsenic, the distribution of the molecular species among the various types at $650^{\circ} \mathrm{C}$ is also illustrated in the last two columns in Table 12.

It is noted that at the $5 \mathrm{ppb}$ level of total atomic arsenic contamination, there is not yet a major interaction with any of the $\mathrm{Ni}$-anode material present. However, as seen in column As-3 of Table I.8, at $5.16 \mathrm{ppb}$ total arsenic content, an equilibrium is established with $\mathrm{Ni}$ in combinaticn with NiAs(c), as would be predicted by Eq. 39. Since both of these compounds are solids at unit activity and nickel is present in large excess in the fuel cell anode compartment, it is clear that this reaction limits the possible gaseous arsenic concentration inside the fuel cell to slightly over $5 \mathrm{ppb}$. This has been an important input for the modeling mechanism recently worked out for arsenic poisoning. For example, it is assumed that any amourt of $\mathrm{As}_{2}(v)$ greater than 10 $\mathrm{ppb}$ will be completely scrubbed from the gas stream at a location close to where it enters the anode compartment.

It is also assumed that NiAs(C), even as a monomolecular film on the nickel surface, is likely to be a major barrier and cause a sharp reduction in the catalytic and electrocatalytic activity of the nickel with regard to $\mathrm{H}_{2}$-oxidation. Therefore, one might expect some overpotential losses even at levels of arsenic contamination lower than $10 \mathrm{ppb}$. Given also the strong tendency to form a quite stable NiAs(c) surface film from either gaseous As-- 
species or $\mathrm{As}^{3+}$-ions, it is estimated that a relatively continuous layer will form everywhere on both the external and internal surfaces of a porous anode. And if all the gaseous As-content in a fuel is fairly rapidly absorbed from the fuel, down to a few parts-per-billion concentration, a sharp, forward creeping front of completely deactivated nickel anode surface will result. The above scenario has been used in our arsenic tolerance modeling as a function of the excess. As-contamination (>10 ppb) and the cumulative time over which poisoning occurs. Also, on the assumption that there is no recovery from As-contamination (i.e., given the high temperature stability of NiAs), the poisoning effect will amount to a continuous accumulation of deactivated nickel anode surface until the fuel is cleaned to below the $10 \mathrm{ppb}$ arsenic level.

\subsection{1 $\mathrm{As}_{2} / \mathrm{AsH}_{3}$ Equilibria with $\mathrm{HC} \ell, \mathrm{H}_{2} \mathrm{~S}_{2}$ and $\mathrm{H}_{2} \mathrm{Se}$}

Since arsenic will strongly react with and condense on nickel surfaces inside the fuel cell, its total vapor pressure in terms of the total atomic concentration entering a fuel cell has to be very low ( $<6 \mathrm{ppb}$ ) over long periods if any poisoning is to be completely eliminated. The preestablished equilibria of arsenic (normally at between 1 and $10 \mathrm{ppm}$ in raw coal-gas), when reacting with other major halide or metalloid contaminants, are therefore of interest even before the gas enters a fuel cell because of the possibility of increased transfer of arsenic through interaction with cocontaminants. These might provide more volatile compounds than otherwise would be able to separately condense out of a fuel while its temperature is being lowered.

Accordingly, Table $I \cdot \sigma$ in Appendix $A$ also provides the equilibrium gas concentrations of $1 \mathrm{ppm}$ total atomic arsenic in the presence of two concentrations each of $\mathrm{HCl}$ and $\mathrm{H}_{2} \mathrm{~S}$, three concentrations of $\mathrm{H}_{2} \mathrm{Se}$, and two concentrations of combined $\mathrm{H}_{2} \mathrm{Se} / \mathrm{HCl}$, all between about 0.5 and $5 \mathrm{ppm}$. It is clear from the very low levels of any of the compounds formed, such as $\mathrm{AsCl}_{3}(g), \mathrm{AsS}_{(\mathrm{g})}$ or AsSe(g), that the presence of $\mathrm{HCl}, \mathrm{H}_{2} \mathrm{~S}$ or $\mathrm{H}_{2} \mathrm{Se}$ has essentially no effect on the distribution of As in the gas phase; the results of columns 1 through 9 in this table bear this out. Even with 5 ppm 
$\mathrm{H}_{2} \mathrm{Se}$ and $5 \mathrm{ppm} \mathrm{HCl}$ simultaneously present, the quantities of AsSe and $\mathrm{AsCl}_{3}$ are less than $0.1 \mathrm{ppb}$, while AsS with 5 ppm $\mathrm{H}_{2} \mathrm{~S}$ present amounts to even less. Hence, no stable, volatile compounds of arsenic appear to be formed among the trace contaminants. Only with the hydrogen in fuel, the volatile gas, $\mathrm{AsH}_{3}$, is formed. Although $\mathrm{AsH}_{3}$ represents only $4 \%$ of the 1 ppm atomic arsenic gas phase (cf. Table I.6), it will become the main species when only 5 ppb total arsenic is present.

\section{$3.6 \mathrm{ZINC}$}

Thermochemical data obtained for $\mathbf{z n}$ vapor species present in fuel gas at from 1 to $20 \mathrm{ppm}$ concentration, interacting with fuel cell components including carbonate electrolyte, are presented in Table IV. 1 of Appendix A. Table 13 summarizes this information as wel]. as some other data from different tables also provided in Appendix $A$, which illustrate additional interactions with the major contaminants (e.g. $\mathrm{H}_{2} \mathrm{~S}, \mathrm{H}_{2} \mathrm{Se}$ or $\mathrm{HC}$ ) if these are simLitaneously present with zinc (cf. Tables I.4, II.8, IV.2, IV.3 and IV.4).

As established in earlier cell tests (Ce11 No. 2-31), up to 15 ppm $\mathrm{Zn}(\mathrm{v})$ in fuel gas can be reasonably tolerated by the carbonate fuel cell operating at normal. (50 to 75\%) fuel utilization levels. But at very high conversions and with higher levels of $\mathrm{Zn}(\mathrm{v})$ in the gas, one observes a good deal of $z$ no(s) deposition toward the anode exit port. Five zinc vapor levels were thus investigated by SOLGASMIX computation: $1,5,10,15$, and $20 \mathrm{ppm}$. The only volatile species of $z$ inc is monatomic $\mathrm{Zn}(\mathrm{g})$. It is seen in Table 13 that the equilibrium $\mathrm{Zn}^{+}$concentration in the melt lies in the 0.2 to $3.2 \mathrm{ppm}$ range for the various $\mathrm{zn}(\mathrm{g})$ levels considered. These are significant levels for a trace species which in this case can potentially cause troubles in terms of its precipitation as $\mathrm{zno}(\mathrm{s})$, especialiy after ions are transfered to the cathode side. However, because the only significant $z h$ vapor species is $\mathrm{z} n(\mathrm{~g})$, we nay expect the attainment of an equiliorium $\mathrm{Zn}^{++}$cation level in the melt to be a slow process as it depends entirely on the dissolution of metallic zinc vapor in the melt as a result of ionization through an oxidation process such as: 
TABLE 13

\section{SUMMARY OF Zn SPECIES AND VARIOUS IONS IN EQUILIBRIUM AT $650^{\circ} \mathrm{C}$}

Separate Equilibria for Zinc with Major Contaminants in Unused Fuel $\left(18 \mathrm{H} \mathrm{H}_{2} \mathrm{O}\right)$ Shows that no solid $\mathrm{ZnO}$, $\mathrm{ZnS}$, or $\mathrm{ZnCl} \ell_{2}$ will Form. However, ZnSe(s) at $\mathrm{High} \mathrm{H}_{2} \mathrm{Se}(\mathrm{v})$ Levels Could Precipitate.

\begin{tabular}{|c|c|c|c|c|c|c|}
\hline $\ln (v)$ & $\mathrm{Zn}^{++}$ & $\mathrm{O}=$ & $\mathrm{ZnO}(\mathrm{v})$ & & & \\
\hline ppm & mol-ppm & mol-r pm & & & & \\
\hline 1 & 0.16 & 0.07 & (infini- & & & \\
\hline 5 & 0.8 & 0.07 & & & & \\
\hline 10 & 1.6 & 0.07 & tesimally & & & \\
\hline 15 & 2.4 & 0.07 & & & & \\
\hline \multirow[t]{3}{*}{20} & 3.2 & 0.07 & $\operatorname{sma} 11$ & & \multicolumn{2}{|c|}{ (no solid zno) } \\
\hline & \multirow{5}{*}{2.4} & \multirow{5}{*}{0.07} & $\mathrm{H}_{2} \mathrm{~S}(\mathrm{~g})$ & $S=(\ell)$ & \multicolumn{2}{|c|}{$\mathrm{ZnS}(\mathrm{g} / \mathrm{s})$} \\
\hline & & & $\mathrm{ppm}$ & mo1-ppm & $\mathrm{ppm}(\mathrm{gas})$ & solid \\
\hline 15 & & & 0.5 & & $0.8 E-9$ & No \\
\hline 15 & & & 1.1 & 4.5 & 1. $7 E-9$ & No \\
\hline \multirow[t]{3}{*}{15} & & & 5 & & $8.0 E-9$ & No \\
\hline & & & $\mathrm{H}_{2} \mathrm{Se}(\mathrm{g})$ & $\mathrm{Se}^{=}(\ell)$ & \multicolumn{2}{|c|}{$\mathrm{ZnSe}(\mathrm{g} / \mathrm{s})$} \\
\hline & & & ppm & mol-ppm & ppn(gas) & solid \\
\hline 15 & & 0.07 & 0.08 & 0.8 & $0.23 E-9$ & No \\
\hline 15 & & 0.07 & 1.25 & 12 & $3.5 E-9$ & No \\
\hline 15 & & 0.07 & 5.0 & 48 & $14 E-9$ & No \\
\hline \multirow[t]{3}{*}{1.5} & & 0.07 & 13 & 125 & $37 E-9$ & znse \\
\hline & & & $\mathrm{HC} \ell(g)$ & $\mathrm{C} \ell^{-}(\ell)$ & \multicolumn{2}{|c|}{$\mathrm{ZnCl} 2(\mathrm{~g} / \mathrm{s})$} \\
\hline & & & ppm & mol-z & ppm(gas) & solid \\
\hline 1.5 & 2.5 & 0.07 & 0.01 & 0.2 & 1. $2 E-9$ & No \\
\hline 15 & 6.4 & 0.09 & 1.0 & 15 & $11 E-6$ & No \\
\hline 15 & & & 5 & $\sim 50$ & $0.3 E-3$ & No \\
\hline 15 & & & 10 & & $1.1 E-3$ & No \\
\hline
\end{tabular}




$$
\mathrm{Zn}(\mathrm{v})+\mathrm{H}_{2} \mathrm{O}+\mathrm{CO}_{2} \longrightarrow \mathrm{Zn}^{++}+\mathrm{CO}_{3}{ }^{+}+\mathrm{H}_{2}
$$

It is interesting to note in Table IV. 1 in Appendix $A$ that the "activity" of $\mathrm{znO}(\ell)$ in equilibrium with the melt and with $15 \mathrm{ppm}$ $\mathrm{Zn}(\mathrm{v})$ is becoming higher at this point than the $\mathrm{K}_{2} \mathrm{CO}_{3}(\ell)$ activity in the melt. This indicates that conditions are approaching a state that could foster the formation of solid zinc oxide. Under the appropriate conditions and after sufficient time to establish the equilibrium $\mathrm{Zn}^{++}$level in the melt, the precipitation of $\mathrm{znO}(\mathrm{s})$ from its liquid ionic species could therefore occur in the electrolyte. Unfortunately, it could also occur directly from the vapor phase on a much shorter time scale. The important reaction in the gas/solid phase is:

$$
\mathrm{Zn}(\mathrm{v})+\mathrm{H}_{2} \mathrm{O}(\mathrm{g}) \longleftrightarrow \mathrm{ZnO}(\mathrm{s})+\mathrm{H}_{2}(\mathrm{~g})
$$

and if we rearrange the equilibrium expression for this reaction, we find that the $\mathrm{H}_{2}$ to $\mathrm{H}_{2} \mathrm{O}$ ratio at and below which $\mathrm{ZnO}(\mathrm{s})$ may form directly, is given by:

$$
\mathrm{p}_{\mathrm{H}_{2}} / \mathrm{p}_{\mathrm{H}_{2} \mathrm{O}}=\mathrm{p}_{\mathrm{Zn}} \times 4.93 \times 10^{4}
$$

At $15 \mathrm{ppm}$ of $\mathrm{Zn}(\mathrm{V})$ in fuel, the above ratio equals 0.74 , a value that is easily attained in the outlet region with a fuel cell operating under high fuel conversion conditions. Thus, the possibility of forming a zno sol of condensed 'particles' in the anode gas which will precipitate in the exit flow channels, as well as in electrode pores, appears realistic. The experimentally observed $\mathrm{ZnO}(\mathrm{s})$ deposits in the gas channels of a fuel cell anode toward the exit, as well as dissolved in the carbonate electrolyte are therefore clear support for these thermochemical calculations. It should be noted that the formation of a condensed phase zno solid is not shown in the present SOLGASMIX computations because these were done only for inlet gas conditions, where $\mathrm{p}_{\mathrm{H}_{2}} / \mathrm{p}_{\mathrm{H}_{2} \mathrm{O}}=\sim 2$. This ratio would not cause immediate deposition or precipitation, even if $40 \mathrm{ppm} z$ inc vapor were initially present in fuel gas, as can be readily calculated. 


\subsubsection{Zinc Equilibria with $\mathrm{H}_{2} \mathrm{~S}, \mathrm{H}_{2} \mathrm{Se}_{\text {, and } \mathrm{HCl}}$}

Formation of zinc chlorides, sulfides and selenides in the gas phase were considered a possible way of transferring $z$ inc in a more volatile form into the fuel cell, and/or precipitating zinc species when the $\mathrm{H}_{2} / \mathrm{H}_{2} \mathrm{O}$ ratio decreases. The result for $\mathrm{Zr} / \mathrm{H}_{2} \mathrm{~S}$ SOLGASMIX computations at different $\mathrm{H}_{2} \mathrm{~S}$ levels are provided in Tables $\mathrm{I} \cdot 4$ and IV. 4 in Appendix A. We see from the summary Table 13 that only the gaseous and the dissolved liquid zinc sulfide, $2 n S(l)$ species, in the form of $\mathrm{Zn}^{++}$and $\mathrm{S}^{=}$ions are present in the melt, but only in relatively minor amounts even with 5 ppm $\mathrm{H}_{2} \mathrm{~S}$ contaminant present. Solid zns is not directly formed in equilibrium with $5 \mathrm{ppm} \mathrm{H}_{2} \mathrm{~S}$ gas in entry fuel at $650^{\circ} \mathrm{C}$ as is also apparent from the minuscule amount of gaseous $\mathrm{ZnS}(\mathrm{g})$ that would be in equilibrium with the system. Comparing $S^{=}$ion levels in Table 13 with those in Table 9 (in the absence of $z$ inc), also shows that sulfide ion concentration is unaffected by the presence of $\mathrm{Zn}^{++}$and vice versa, which is not the case for the chloride ion interactions which will be discussed further on.

Again, although not in the entry passages, there is some likelihood of precipitating $\mathrm{ZnS}(\mathrm{s})$ at the lower $\mathrm{H}_{2}$ partial pressure that occur in the exit gas of a fuel cell. This could be considered a true antagonistic, as opposed to synergistic effect, were it not for the greater tendency to form $\mathrm{ZnO}$ as shown in Eq. [41]. For comparison, the following equilibriurn reaction is considered:

$$
\mathrm{Zn}(\mathrm{V})+\mathrm{H}_{2} \mathrm{~S}(\mathrm{~g}) \longleftrightarrow \mathrm{ZnS}(\mathrm{S})+\mathrm{H}_{2}(\mathrm{~g})
$$

To establish the partial pressure of $\mathrm{H}_{2} \mathrm{~S}$ which is needed to form $\mathrm{ZnS}(\mathrm{s})$ at various $\mathrm{Zn}(\mathrm{v})$ and $\mathrm{H}_{2}$ concentrations, we rearrange the equilibrium expression for $\mathrm{Eq} \cdot 43$ and $\mathrm{Eind}$

$$
\mathrm{p}_{\mathrm{H}_{2} \mathrm{~S}}=\left(\mathrm{p}_{\mathrm{H}_{2}} / \mathrm{p}_{\mathrm{Zn}}\right) \times 9.75 \times 10^{-10}
$$

At a $\mathrm{Zn}$ partial pressure of $15 \mathrm{ppm}$ and 0.36 atm. of $\mathrm{H}_{2}$, this relationship shows that the partial pressure of $\mathrm{H}_{2} \mathrm{~S}$ must be above $23 \mathrm{ppm}$ for $\mathrm{ZnS}(\mathrm{s})$ to form. However, for the same $\mathrm{Zn}$ level, if the $\mathrm{H}_{2}$ partial pressure were reduced to $\sim 10 \%$ in the anode exit gas due to $-80 \%$ fuel utilization, the overall $\mathrm{H}_{2} \mathrm{~S}$ partial pressure would 
have to be kept below $5 \mathrm{ppm}$ in order to prevent $\mathrm{ZnS}(\mathrm{s})$ from forming. However, this is academic since $5 \mathrm{ppm} \mathrm{H}_{2} \mathrm{~S}$ in fuel is already well beyond the tolerance level of the carbonate fuel cell. Therefore, $\mathrm{znS}(\mathrm{s})$ appears of little concern, except that $\mathrm{zinc}$ in remaining vapor form could absorb the effect of a small amount of sulfur when the exit fuel is oxidized to be recycled to the cathode side of the cell.

In connection with the effects of zinc in the presence of selenium, it was not possible to provide a CIST treatment for calculating the "activity" of znse(l) needed to determine its ionic concentrations, because the free energy of formation of this pure liquid species could not be found. However, gaseous phase and pure solid ZnSe were treated as shown in Tables I. 4 and II. 8 of Appendix A. Comparing summary Tables 10 and 13 , it is noted that $\mathrm{Zn}(\mathrm{v})$ and $\mathrm{H}_{2} \mathrm{Se}(\mathrm{g})$ also do not affect each other's volatility and, when simultaneously present, they combine to form only extremely low concentrations of the znse gaseous species.

However, in spite of only low vapor phase levels of $\mathrm{ZnSe}(\mathrm{g})$ (at the higher levels of $\mathrm{Zn}$ and $\mathrm{H}_{2} \mathrm{Se}$ ), it is seen that $\mathrm{ZnSe}(\mathrm{s}$ ) is a very stable pure solid and can already sublimate at such low concentrations. Solid znse can also form at lower $\mathrm{H}_{2}$ Se levels if the $\mathrm{H}_{2}$ partial pressure becomes much lower, or the $\mathrm{Zn}(\mathrm{g})$ levels are quite high. This can easily be appreciated by considering the selenide equivalent to the zinc sulfide reaction:

$$
\mathrm{Zn}(\mathrm{v})+\mathrm{H}_{2} \mathrm{Se}(\mathrm{g}) \longleftrightarrow \mathrm{ZnSe}(\mathrm{s})+\mathrm{H}_{2}
$$

At $923 \mathrm{~K}$, the equilibrium constant for this reaction can be rearranged to provide the partial pressure of $\mathrm{H}_{2}$ Se at which solid znse(s) forms for given levels of $\mathrm{H}_{2}$ and $\mathrm{Zn}(\mathrm{v})$ :

$$
\mathrm{p}_{\mathrm{H}_{2} \mathrm{Se}}=\left(\mathrm{p}_{\mathrm{H}_{2}} / \mathrm{p}_{\mathrm{Zn}}\right) \times 5.66 \times 10^{-10}
$$

Thus as for $\mathrm{ZnS}(\mathrm{s})$, there is some (slightly greater) danger of forming $\mathrm{ZnSe}(\mathrm{s})$ in the ancde because at the $15 \mathrm{ppm} \mathrm{Zn}(\mathrm{V})$ level and only $13 \mathrm{ppm} \mathrm{H}_{2} \mathrm{Se}$ (at inlet conditions), solid znse can already form. However, at the same $2 n(v)$ level but in the exit gas with $\sim 10 \% \mathrm{H}_{2}$ remaining in the fuel, the $\mathrm{H}_{2} \mathrm{Se}(\mathrm{g})$ partial pressure must never increase much above $2 \mathrm{ppm}$. Hence selenium reacts more 
actively with zinc than with sulfur. Finally, since we did not simultaneously obtain the $\mathrm{Zn}^{++}$and $\mathrm{Se}^{-}$ion species, which would have been derived from CIST considerations, we cannot make any quantitative statements regarding the effect of their joint presence on concentrations in the melt. However, by analogy to the $\mathrm{H}_{2} \mathrm{~S} / \mathrm{Zn}$ system at equilibrium, it is not expected that $\mathrm{Zn}^{++}$and $\mathrm{Se}^{=}$ ion interactions will affect each other in the melt on the anode side.

Finally, the effects of $z$ inc in the presence of two different levels of $\mathrm{HCl}$ with five different levels of $\mathrm{Zn}(\mathrm{V})$ are shown in Tables IV.2 and IV. 3 of Appendix A. They are also available in summarized form in Table 13. Generally, halides appear to interact stronger with zinc both in the gas phase and in the carbonate melt than do other contaminants. But HCl and $\mathrm{Zn}(\mathrm{v})$ do not easily form stable solid deposits of $\mathrm{ZnCl}_{2}(\mathrm{~s})$ at fuel cell temperatures. Furthermore, it is evident from the partial pressures of gaseous $\mathrm{ZnCl}_{2}(\mathrm{v})$, which are small but considerably higher than for $\mathrm{ZnS}(\mathrm{v})$ or $\mathrm{ZnSe}(v)$, that at high chloride anion content (15 molis in the melt for $1 \mathrm{ppm} \mathrm{HCl}$ in fuel gas), the liquid interaction product $\mathrm{znCl}_{2}$, in terms of dissociated ionic species forms to a considerably greater extent than is true with $\mathrm{znS}$ or $\mathrm{ZnSe}$.

It is clear, therefore, when comparing the concentrations of $\mathrm{Zn}^{++}$cations in the melt in equilibrium with $15 \mathrm{ppm} \mathrm{zn}(\mathrm{v})$, both alone and in the presence of $1 \mathrm{ppm} \mathrm{HCl}(\mathrm{g})$, that $\mathrm{HCl}$ interacts more actively with $\mathrm{Zn}$ in the melt to produce an almost $3 \times$ greater $\mathrm{Zn}^{++}$ equilibrium concentration. It is to be noted, however, that $\mathrm{zn}$ ions do not affect the much higher absolute level of $\mathrm{Cl}^{-}$anion concentration in the melt. On the other hand, the computed tables show that there is a very slight $\mathrm{Zn}^{++}$ion effect slightly increasing the $\mathrm{O}=$ anion concentration beyond the value which had already been increased by the higher $\mathrm{Cl}^{-}$concentrations. However, compared to the much larger $\mathrm{OH}^{-}$content in carbonate melt, the effect of $\mathrm{O}^{=}$ variation is negligibly small. The increased anion concentrations of both these oxygen species do imply a slight melt alkalizing effect due to the presence of both $\mathrm{HCl}$ and $\mathrm{zn}$. 
On the whole, the fact that $\mathrm{Zn}$ metal vapor species only slowly enter the melt due to the complex kinetics for forming $\mathrm{Zn}^{++}$ions (cf. Eq. 40) may mean that, in addition to the low concentrations of $\mathrm{S}, \mathrm{Se}$ and $\mathrm{HCl}$, contaminant effects due to zinc interactions with halides and metalloids will always be relatively unimportant. of some concern, however, is that $\mathrm{znO}(\mathrm{s})$ deposition, the initial oxidation product of the gas phase interaction with steam, could (toward the anode chamber exit) provide "already oxidized" bulk quantities of zinc material which would more rapidly dissolve in the carbonate melt. This would follow as a consequence of the much simpler reaction (kinetically speaking) than the one shown by Eq. 40:

$$
\mathrm{ZnO}(\mathrm{s})+\mathrm{CO}_{2}(\mathrm{~g}) \longleftrightarrow \mathrm{Zn}^{++}+\mathrm{CO}_{3}{ }^{\mathrm{H}}
$$

Hence, it is expected that a greater amount of $\mathrm{Zn}^{++}$-ion will then rapidly appear in the electrolyte that wets the anode toward the fuel exit side.

\subsection{LEAD}

Thermochemical computations for lead (Pb) in fuel gas which also contains various amounts of the major contaminants, are provided from 0.1 to $2.55 \mathrm{ppm} \mathrm{Pb}(\mathrm{V})$ concentrations and also with and without interactions with the various fuel cell components (including carbonate electrolyte). These data for $\mathrm{Pb}$ are presented in Tables I.1, II.7, and III.1, III.2, III.3 in Appendix A. Important information from these tables has been summarized in Table 14. Experimentally, in some of the original out-of-cell work which primarily employed TGA-experiments (9), it was established that only up to $2 \mathrm{ppm} \mathrm{Pb}$ vapor could be blended in fuel gas which then showed some degree of interaction with dry nickel anode material, but none with a carbonate-wetted coupon of porous nickel.

It has now also been determined from SoLGASMIX computations that as an elemental vapor species, $\mathrm{Pb}(\mathrm{V})$ alone cannot be present at $650^{\circ} \mathrm{C}$ in greater than $2.55 \mathrm{ppm}$ concentration in fuel gas because this is its theoretical saturation vapor pressure in equilibrium with the pure liquid species $\mathrm{Pb}(\ell)$. It is for that reason that we performed most calculations with pure condensed phase $\mathrm{Pb}(\ell)$ present 
TABLE 14

\section{SUMMARY OF Pb SPECIES AND VARIOUS IONS IN EQUILIBRIUM AT $650^{\circ} \mathrm{C}$}

Separate Equilibria for Lead with the Major Contaminants in Unused Fuel but with $18 \% \mathrm{H}_{2} \mathrm{O}$, Shows that No solid $\mathrm{PbO}$, PbS, or $\mathrm{PbCl}_{2}$ will Form. However, PbSe(s) at $\mathrm{High} \mathrm{H}_{2} \mathrm{Se}(\mathrm{v})$ Levels Could Precipitate.

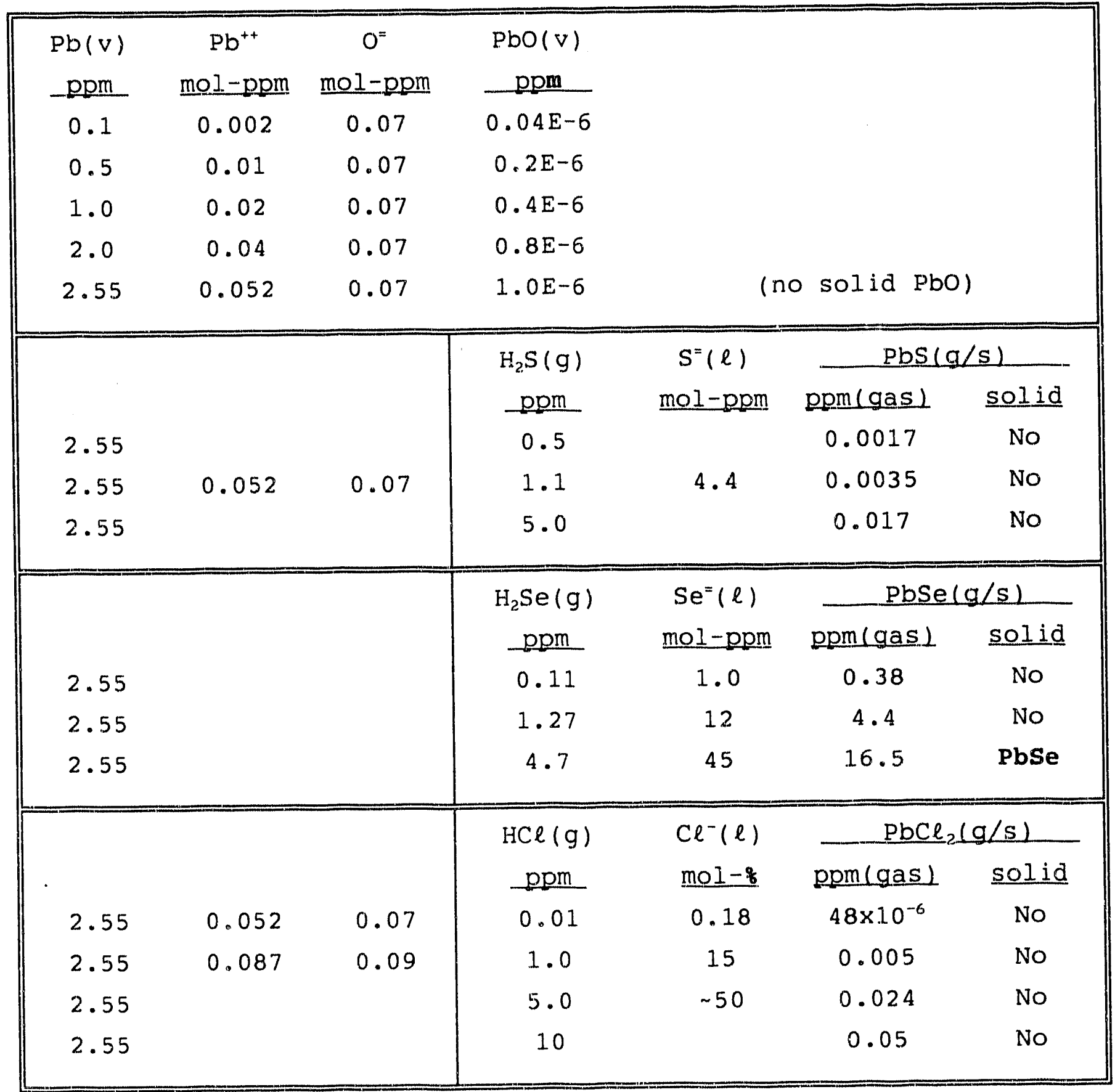


when investigating its behavior for the highest possible lead vapor pressure possible at $650^{\circ} \mathrm{C}$. In recent experiments with bench-scale fuel cells, it was also observed - possibly because of an oxide or hydroxide film already present on the contaminant source material that at slightly below $650^{\circ} \mathrm{C}$, it was difficult to introduce more than $1 \mathrm{ppm}$ of $\mathrm{Pb}(\mathrm{v})$ in fuel gas so as to simulate a coal-gas contamination at its highest level.

The important gas/solid reaction of lead, if any kind of equilibrium with a condensed $\mathrm{Pb}$-oxide (or -hydroxide) phase could exist in the presence of $2.55 \mathrm{ppm} \mathrm{Pb}(\mathrm{v})$ vapor, would be as follows for the most stable hydroxide product that might form:

$$
\mathrm{Pb}(\mathrm{V})+2 \mathrm{H}_{2} \mathrm{O} \longrightarrow \mathrm{Pb}(\mathrm{OH})_{2}(\mathrm{~s})+\mathrm{H}_{2}
$$

When the equilibrium constant for this reaction is determined, however, and the expression is rearranged to provide a $\mathrm{H}_{2} / \mathrm{H}_{2} \mathrm{O}$ ratio at which $\mathrm{Pb}(\mathrm{OH})_{2}(\mathrm{~s})$ could form, it is evident from:

$$
\mathrm{p}_{\mathrm{H}_{2}} / \mathrm{p}_{\mathrm{H}_{2} \mathrm{O}}^{2}=\mathrm{p}_{\mathrm{Pb}} \times 1.46 \times 10^{-4}
$$

that this equilibrium lies almost entirely on the left-handed side of Eq. 48. Even with only $0.1 \% \mathrm{H}_{2}$ remaining in the fuel and with very high $\mathrm{H}_{2} \mathrm{O}$ content, the value of this $\mathrm{H}_{2} / \mathrm{H}_{2} \mathrm{O}^{2}$ ratio for hydroxide deposition is much larger than the small $\mathrm{Pb}(\mathrm{V})$ value required for metallic $\mathrm{Pb}$-deposition.

When Table 13 for $\mathrm{Zn}$ and Table 14 for $\mathrm{Pb}$ are examined, it is evident that both cation species are readily soluble in the melt, but they are in equilibrium with only extremely small amounts of the oxide or hydroxide vapor species that can exist in the gas phase. However, $\mathrm{ZnO}(\mathrm{s})$ is much more stable than solid Pbo or $\mathrm{Pb}(\mathrm{OH})_{2}$ formed directly or from the $\mathrm{Pb}^{++}$-cation and $\mathrm{O}^{=}$(or $\mathrm{OH}^{-}$) concentrations in the melt. Pre-entry deposition of oxidized lead solids or formation inside the fuel cell is, therefore, extremely unlikely, but when high levels of $\mathrm{Pb}(\mathrm{v})$ from a gasification process are cooled to fuel cell temperature, it is clear that droplets of liquid lead may form on the pipe walls. In contrast, liquid zinc in a humid fuel environment will readily transform to $\mathrm{Zn}$ vapor and $\mathrm{ZnO}(\mathrm{s})$ if sufficient $\mathrm{H}_{2} \mathrm{O}$ is available. This has also been 
experimentally observed in our contaminant addition reactors for bench-scale fuel cell testing.

Thus, it is assumed, because of the unlikely occurrence of oxidized lead species existing in either gaseous, liquid or solid form which could lead to similar reactions as shown by Eqs. 40 or 47, that these reactions do not occur with $\mathrm{Pb}$ contamination. Instead, only very low levels of $\mathrm{Pb}$-ions may be slowly formed in the melt in equilibrium with very small amounts of $\mathrm{O}^{=}$and $\mathrm{OH}^{-}$ anions. This would explain the absence of any notable reaction of $\mathrm{Pb}(\mathrm{v})$ with carbonate wetted nickel in our early TGA experiments (9), whereas the obvious reaction of $\mathrm{Pb}(\mathrm{v})$ increasing the weight of dry Ni-anode material can be envisioned as direct alloy formation at the surface:

$$
\mathrm{Pb}(\mathrm{v})+\mathrm{Ni}(\mathrm{c}) \longleftrightarrow \mathrm{NiPb} \text { (surface) }
$$

Since there are no readily available thermodynamic data to estimate the likelihood of such alloy products forming for the likelihood that such alloys would poison the surface of nickel as a catalyst, they were not investigated at this time.

\subsubsection{Lead Equilibria with $\mathrm{HCl}, \mathrm{H}_{2} \mathrm{~S}$, and $\mathrm{H}_{2} \mathrm{Se}$}

The relevant data for these multiple contaminant interactions in the presence of both fuel gas constituents and fuel cell components are presented in the Tables of Appendix $A$, and are summarized in Table 14. All of these values were calculated in the presence of a saturated $\mathrm{Pb}(\mathrm{V})$ concentration held in equilibrium with some condensed phase lead, $\mathrm{Pb}(\ell)$. No major interactions were found except for the case of considerable gaseous PbSe formation (i.e., 16.5 pprn) which can accumulate in larger concentration than that of either individual reactant ( $\mathrm{Pb}$ or $\mathrm{Se}$ ). Thus, a possible equilibrium deposition of $\operatorname{PbSe}(\mathrm{s})$ (when $>4.7 \mathrm{ppm} \mathrm{H}_{2} \mathrm{je}(\mathrm{g})$ is also present) could be of concern if prereacted, gaseous, PbSe forms well before the fuel cell entry and then transfers a combination of these trace species into the cell.

It is interesting to note that with an equivalent situation of $\sim 5 \mathrm{ppm} \mathrm{HCl}$ or $\mathrm{H}_{2} \mathrm{~S}$ present, only 24 and $17 \mathrm{ppb}$ ( 6 orders of magnitude lower) gaseous equilibrium pressures of $\mathrm{PbCl}_{2}$ and $\mathrm{PbS}$ 
will occur with no possible formation of condensed solids. This points, both in the case of $\mathrm{Zn}$ and $\mathrm{Pb}$, to the much higher stability of the metallic selenides both in the gaseous as well as condensed phases when compared to chlorides or sulfides, all at $650^{\circ} \mathrm{C}$. Fortunately for hot-gas cleanup purposes, the saturated equilibrium volatility of $\mathrm{znSe}(\mathrm{v})$, in equilibrium with its solid phase (cf. Table 13) is much smaller (i.e, $37 \times 10^{-14} \mathrm{~atm}$ ) than for saturated $\operatorname{PbSe}(\mathrm{v})$ which as we mentioned is $16.5 \times 10^{-6} \mathrm{~atm}$.

Another noteworthy effect is that with only $1.27 \mathrm{ppm}_{2} \mathrm{Se}$ in equilibrium with $2.5 \mathrm{ppm}$ saturated $\mathrm{Pb}(\mathrm{V})$ vapor, $4.4 \mathrm{ppm}$ gaseous PbSe(v) can exist which is able to deposit as solid $\mathrm{PbSe}(\mathrm{s})$ on fuel cell components, especially at the lower hydrogen activity of fuel toward the anode exit. This is based on the equilibrium expression for the reaction:

$$
\mathrm{Pb}(\mathrm{V})+\mathrm{H}_{2} \mathrm{Se} \longrightarrow \mathrm{PbSe}(\mathrm{s})+\mathrm{H}_{2}
$$

from which we can obtain an expression for the different $\mathrm{H}_{2} \mathrm{Se}$ activities that may bring about $\mathrm{PbSe}(\mathrm{s})$ formation if saturated $\mathrm{Pb}(\mathrm{v})$ is present at $650^{\circ} \mathrm{C}$ :

$$
p_{\mathrm{H}_{2} \mathrm{Se}}=\left(\mathrm{p}_{\mathrm{H}_{2}} / \mathrm{p}_{\mathrm{Pb}}\right) \times 3.33 \times 10^{-11}
$$

For example, it can be calculated that at about $80 \%$ fuel utilization with $10 \% \mathrm{H}_{2}$ (total. Euel value) left in the exit gas this will allow $1.3 \mathrm{ppm}_{2} \mathrm{Se}$ concentration to establish equilibrium with solid PbSe while its vapor will be at a level of $4 \mathrm{ppm}$ in the exit gas. Thus at low hydrogen partial pressures and saturated $\mathrm{Pb}(v)$ volatility, besides dissolution in the melt, there is also a clear possibility of depositing $\operatorname{PbSe}(\mathrm{s})$ from the gas phase which could cause pore blockage or particulates to form in the anode gas channels, especially in anode outlet locations. In the absence of a CIST treatment for $\mathrm{Pb}^{++}$together with $\mathrm{Se}^{=}$ions in carbonate melt, it is not yet possible to show to what extent ionized Pbse species in solution may form or what the effect of each ion in the other's presence will be in the melt. 


\subsection{CADMIUM}

The thermochemical data analyzed for cd vapor species in fuel gas at from 0.1 to $20 \mathrm{ppm}$ concentration and interacting with fuel cell components (including carbonate electrolyte) are presented in Table IV. 5 of Appendix A. The following summary shown in Table 15, presents this information as well as additional data from other tables illustrating $C d$ interactions with different contaminants (e.g. $, \mathrm{H}_{2} \mathrm{~S}, \mathrm{H}_{2} \mathrm{Se}$ and $\mathrm{HCl}$ ) when these are present simultaneously with cadmium (cf. Table I.5, IV.6, IV·7, and IV.8).

As was established in a recent cell test (Cell No. 7-213), up to $33 \mathrm{ppm} C \mathrm{~d}(\mathrm{v})$ in fuel gas appears to be readily tolerated by the carbonate fuel cell when operated at a normal $75 \%$ fuel utilization level. This is more than $6 \mathrm{x}$ the cd level of $5 \mathrm{ppm}$ (cf. Table 1) found to exist on the average in raw coal-gas. When Cell 7-213 was momentarily and inadvertently operated on as high as $73 \mathrm{ppm} C d(\mathrm{v})$, the cell did show some decay, but this was readily recovered. Namely, it proved to be related primarily to plugging of the anode exit tubes where temperatures are considerably lower. Easily removed condensed $\mathrm{Cd}$ (and $\mathrm{CdO}$ ) solids were found to be the cause of the plugging, and when the exit tubes were cleaned out, the performance recovered without interrupting cell operation.

Six cadmium levels were treated by SOLGASMIX computation; 0.1 , $0.5,1,5,10$ and $20 \mathrm{ppm}$, and five of these are summarized in Table 15. The only major volatile species at $650^{\circ} \mathrm{C}$ was found to be monatomic $C d(v)$. It should be noted here that to apply conformal ionic solution computations (CIST) to the cadmium system, it was necessary to use the free energies of solid $\mathrm{CdCO}_{3}(\mathrm{~s}), \mathrm{Cd}(\mathrm{OH})_{2}(\mathrm{~s})$, and $\mathrm{CdO}(\mathrm{s})$ as the reference states for the melt's thermodynamic calculations. This was necessary because the liquid state properties - where these species are also known to be nearly stable in the liquid state at fuel cell temperature - were not available but are assumed to be close to the free energy properties of the solid species.

It is seen in Table 15 that cadmium, as an ionic species compared to $\mathrm{Zn}$ and $\mathrm{Pb}$ cations, exists at only very low levels (<mol-ppb range) in carbonate electrolyte. The highest $\mathrm{Cd}^{++}$ fraction was found to be only about $1.56 \times 10^{-10}$ at the $20 \mathrm{ppm} \mathrm{Cd}(\mathrm{v})$ 
TABLE 15

SUMMARY OF CA SPECIES AND VARIOUS IONS IN EQUILIBRIUM AT $650^{\circ} \mathrm{C}$

Separate Equilibria for Cadmium with the Major Contaminants in Unused Fuel with $18 \% \mathrm{H}_{2} \mathrm{O}$, Shows that no Solid CdO, CdS, CdSe, or $\mathrm{CdCl}_{2}$ will Form in the Carbonate Fuel Cell.

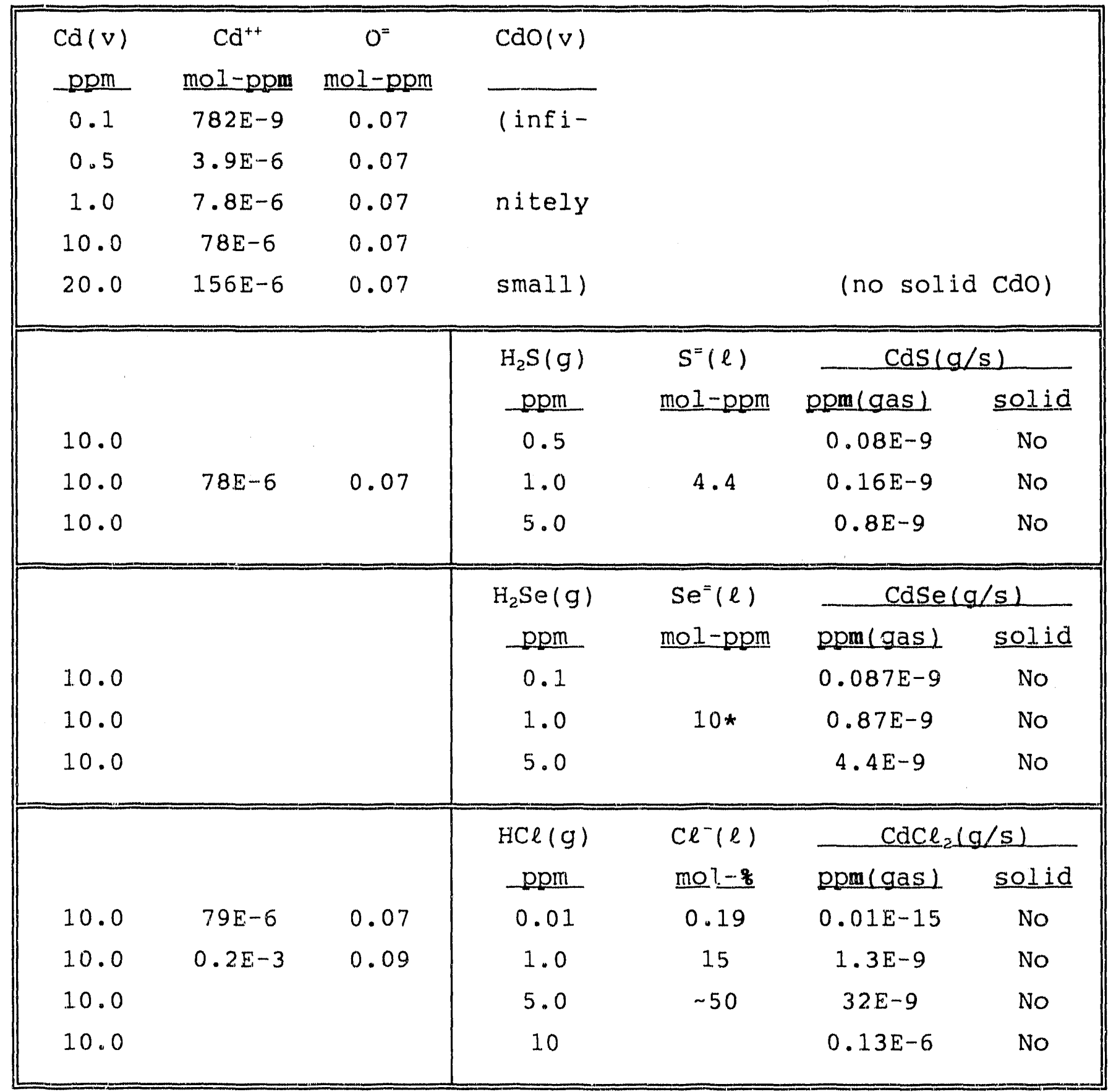

* estimated 
vapor level. The dissolution and cation formation rate in the melt is likely to be also slow for the same reasons mentioned for the other metallic vapors, in that oxidation of any gaseous metal atom at the carbonate melt surface (in a highly reducing environment) meets a complex reduction/oxidation barrier which requires a large activation energy to overcome.

As also mentioned in connection with the other metals, formation of oxidized cadmium directly in the vapor phase could provide a faster dissolution path. The important gas-solid reaction is:

$$
\mathrm{Cd}(\mathrm{v})+\mathrm{H}_{2} \mathrm{O}(\mathrm{g}) \longleftrightarrow \mathrm{CdO}(\mathrm{s})+\mathrm{H}_{2}
$$

When rearranging the equilibrium expression for this reaction, we find that the $\mathrm{H}_{2} / \mathrm{H}_{2} \mathrm{O}$ ratio at which CdO(s) may form directly, is given by:

$$
\mathrm{p}_{\mathrm{H}_{2}} / \mathrm{p}_{\mathrm{H}_{2} \mathrm{O}}=\mathrm{p}_{\mathrm{Cd}} \times 79 \times 10^{-3}
$$

Thus, even with $50 \mathrm{ppm}$ of $\mathrm{Cd}(\mathrm{v})$ in the fuel, the above ratio equals $3.9 \times 10^{-6}$, a ratio which is negligibly small. But with the much larger equilibrium constants occurring at lower temperatures, deposition of oxides (or hydroxides) may occur in the exit pipes, or toward the cathode side of the fuel cell if the anode exit fuel becomes completely oxidized during recycle oxidation of spent fuel. This latter occurence may prove to be of some concern and should be turther investigated.

\subsubsection{Cadmium Equilibria with $\mathrm{HCl}, \mathrm{H}_{2} \mathrm{~S}$ and $\mathrm{H}_{2} \mathrm{Se}$}

The formation of cadmium chloride, sulfide and selenide in the gas phase were also considered as possible ways of transfering cadmium as stable, volatile species into the fuel cell. It could deposit as the solid cadmium salt of these anions when $\mathrm{H}_{2}$ level decreases. The results for the $\mathrm{Cd} / \mathrm{H}_{2} \mathrm{~S}$ SOLGASMIX computations at different $\mathrm{H}_{2} \mathrm{~S}$ concentrations are presented in Tables $\mathrm{I} \cdot 5$ and IV. 8 of Appendix A. From Summary Table 15, it is clear that only the gaseous and dissolved CdS species (in the form of $\mathrm{Cd}^{++}$and $\mathrm{S}^{=}$ions) can be present, and then only in extremely small amounts. It can be calculated that even $20 \mathrm{ppm} \mathrm{Cd}(\mathrm{v})$ and $10 \mathrm{ppm} \mathrm{H}_{2} \mathrm{~S}(\mathrm{~g})$ in fuel, 
carnot deposit solid Cas whether directly from the gas phase or from an equilibrium liquid phase.

The direct gas phase reaction with $\mathrm{H}_{2} \mathrm{~S}$ is written as:

$$
\mathrm{Cd}(\mathrm{v})+\mathrm{H}_{2} \mathrm{~S} \longrightarrow \mathrm{CoS}(\mathrm{s})+\mathrm{H}_{2}
$$

Rearranging the equilibrium expression for Eq. 55, we find:

$$
\mathrm{p}_{\mathrm{H}_{2} \mathrm{~S}}=\left(\mathrm{p}_{\mathrm{H}_{2}} / \mathrm{p}_{\mathrm{Cd}}\right) \times 6.5 \times 10^{-6}
$$

It is immediately evident by comparison with $\mathrm{Eq} .44$, that an $\mathrm{H}_{2} \mathrm{~S}(\mathrm{~g})$ level many orders of magnitude greater than in the case of $\mathrm{ZnS}(\mathrm{s})$ Eormation must be present before CdS(s) will deposit. Even if 50 ppm $C d(v)$ is present, about 1.3 vol.s of $\mathrm{H}_{2} \mathrm{~S}$ would be required in fuel cell exit-gas containing less than $10 \% \mathrm{H}_{2}$.

In connection with possible CaSe(s) formation, Table 15 shows that at the high contaminant levels of $10 \mathrm{ppm} \mathrm{Cd}(\mathrm{v})$ and $5 \mathrm{ppm}$ $\mathrm{H}_{2} \mathrm{Se}(\mathrm{g})$ where the latter is well above fuel cell anode tolerance, there is no solid deposition reaction. And only extremely low Case(v) volatility will occur if any molecular association of these elements were to take place. As for possible $\mathrm{CaCh}_{2}(\mathrm{~s})$ formation, Table 15 also shows that, even at high $\mathrm{Cu}$ and very high $\mathrm{HCl}$. contaminant levels, there is no solid deposition of $\mathrm{CdCl}_{2}(s)$ species. As usual with HCl, and probably with all types of halide contamination at relatively low gas phase concentrations, there is a large fraction of $\mathrm{CO}_{3}{ }^{*}$ anion replaced by $2 \mathrm{C} \ell^{-}$ions. Normally with metalic contaminants, this tends to allow slightiy larger equilibrium amounts of metal cations to form in the melt. However, as in the case of $\mathrm{Zn}$ and $\mathrm{Pb}$, the additional amount of metal cations dissolving occurs only noticeably at a very much higher absulute cation level compared to the very small ppo levels that are possible of $\mathrm{Ca}^{++}$ion.

\subsection{MERCURY}

Thermochemical computations were also done for $\mathrm{Hg}$, similar to those performed for the $\mathrm{Zn}, \mathrm{Pb}$, and $\mathrm{Cd}$, metallic vapor species in fut gas, all in the presence and absence of fuel cell components. 
Mercury in any fuel atmosphere at room temperature is already volatile to the extent of $2.5 \mathrm{ppm}$ vapor concentration. Hence, at slightly elevated temperature it is not difficult to add large mercury concentrations to a coal-gas. However, it is rather an inert metallic vapor even at fairly high temperatures and has not been found to be present in coal-gas to any significant extent (i.e., only 0.5 to $1.0 \mathrm{ppm}$ ). This was calculated from the average content in normal coal deposits $(5,8)$, as has already been ijlustrated in Table 1. Consequently, Hg(v) concentrations in the SOLGASMIX computations were only investigated between 1.0 and 30 ppm, which is already greatly in excess of what can normally be present.

It was established in an earlier program during TGA experimental testing (9), that $\mathrm{Hg}(\mathrm{V})$ even at $35 \mathrm{ppm}$ concentration (i.e., at more than $50 x$ its normal coal-gas level), does not react with either dry or carbonate-wetted, $\mathrm{Ni}$-anode material. These experiments and the thermochemical computations discussed below, as well as the data confirming negligible amalgam formation with nickel, have thus led to the conclusion that mercury is an inert fuel constituent as far as any carbonate fuel cell is concerned, at least in terms of its anode reactions. Hence Hg(v), presumably, is passed right through the anode chamber in unchanged form although this has not yet been confirmed in actual bench-scale cells, only in thermogravimetric analysis (TGA) experiments.

When the various computer runs presented in Appendix $A$ in Tables I.2, IV.9, IV.10, IV.11, and IV. 12 are summarized, as shown in Table 16, and compared to the other metal vapor summaries, it is quickly noted that thermodynamic evidence fully supports this inertriess of $\mathrm{Hg}(\mathrm{v})$ as was found in our experiments. All the various interactions of $30 \mathrm{ppm} \mathrm{Hg}(\mathrm{V})$ with $10 \mathrm{ppm} \mathrm{HCl}$ and with $18 \%$ steam in fuel gas (in equilibrium with 0.07 mol-ppm $0^{*}$ in the melt) show that no solids and only extremely low ppt $\left(10^{-12}\right)$ levels of gaseous oxide/hydroxide and chloride compounds can be formed. Furthermore, with $5 \mathrm{ppm} \mathrm{H}_{2} \mathrm{~S}$ and $5 \mathrm{ppm} \mathrm{H}_{2}$ Se, it is again clear that no solids and only very low ppb $\left(10^{-9}\right)$ levels of gaseous mercury sulfide or selenide compounds can be formed. 
TABI,E 16

\section{SUMMARY OF Hg SPECIES AND VARIOUS IONS IN EQUILIBRIUM AT $650^{\circ} \mathrm{C}$}

Separate Equilibria of Mercury with the Major Contaminants in Unused Fuel with $18 \% \mathrm{H}_{2} \mathrm{O}$, Shows that no Solid HgO, HgS, $\mathrm{HgSe}$, or $\mathrm{HgCl}_{2}$ will Form.

\begin{tabular}{|c|c|c|c|c|c|c|}
\hline $\mathrm{Hg}(\mathrm{V})$ & $\mathrm{Hg}^{++}$ & $O^{=}$ & $\mathrm{HgO}(\mathrm{v})$ & \multirow{7}{*}{\multicolumn{2}{|c|}{ (no solid HgO) }} & \\
\hline $\mathrm{ppm}$ & mol-ppt & mol-ppm & ppt & & & \\
\hline 1.0 & $0.02 \mathrm{E}-6$ & 0.07 & $0.4 E-6$ & & & \\
\hline 5.0 & $0.1 E-6$ & 0.07 & $2 E-6$ & & & \\
\hline 10 & $0.2 E-6$ & 0.07 & $4 E-6$ & & & \\
\hline 20 & $0.5 E-6$ & 0.07 & $8 \mathrm{E}-6$ & & & \\
\hline 30 & $0.7 E-6$ & 0.07 & $13 E-6$ & & & \\
\hline \multirow{5}{*}{$\begin{array}{l}30 \\
30 \\
30\end{array}$} & \multirow{5}{*}{0.057} & \multirow{5}{*}{0.07} & $\mathrm{H}_{2} \mathrm{~S}(\mathrm{~g})$ & $S^{*}(\ell)$ & \multicolumn{2}{|c|}{$\mathrm{HgS}(\mathrm{g} / \mathrm{si})$} \\
\hline & & & opm & mol-ppm & ppt (gas) & solid \\
\hline & & & 0.5 & & $1.4 E-3$ & No \\
\hline & & & 1.1 & 4.4 & $2.9 E-3$ & No \\
\hline & & & 5.0 & & $14 \mathrm{E}-3$ & No \\
\hline \multirow[b]{3}{*}{30} & & & $\mathrm{H}_{2} \mathrm{Se}(\mathrm{g})$ & $\mathrm{Se}^{\prime}(\ell)$ & \multicolumn{2}{|c|}{$\mathrm{HgSe}(\mathrm{g} / \mathrm{s})$} \\
\hline & & & ppm & mol-ppm & ppt (gas) & solid \\
\hline & & & 0.1 & & $0.8 E-3$ & No \\
\hline 30 & & & 1.0 & & $8 E-3$ & No \\
\hline \multirow[t]{3}{*}{30} & & & 5.0 & & $40 E-3$ & No \\
\hline & \multirow{5}{*}{$0.8 E-6$} & \multirow{5}{*}{0.09} & $\mathrm{HCl}(\mathrm{g})$ & $\mathrm{C} \ell^{-}(\ell)$ & \multicolumn{2}{|c|}{$\mathrm{HgCl}(\mathrm{g} / \mathrm{s})$} \\
\hline & & & ppm & mol-8 & ppt (gas) & solid \\
\hline 30 & & & 1.0 & 15 & $0.4 \mathrm{E}-6$ & No \\
\hline 30 & & & 5.0 & $\sim 50$ & $2 \cdot 2 E-6$ & No \\
\hline 30 & & & 10 & & $4.4 \mathrm{E}-6$ & No \\
\hline
\end{tabular}


The Mercury cation levels $\left(\mathrm{Hg}^{++}\right)$in equilibrium in the melt with $30 \mathrm{ppm} \mathrm{Hg}(\mathrm{v})$ are also extremely low, (e.g., $0.8 \times 10^{-18}$ ) in terms of cation mole fraction in the presence of $1 \mathrm{ppm} \mathrm{HCl}$. However, for sulfide (and presumably selenide) anion presence in the melt, this fraction becomes about $10^{6}$ times greater compared to the mercury oxide or chloride presence, which indicates that the sulfides and selenides are somwhat more stable, ionizable liquid species. The actual concentrations, however, are still only in the parts per trillion level. Clearly mercury in coal-gas is of no great concern in connection with anode poisoning. But since $\mathrm{Hg}$, like cadmium, passes right through the fuel cell, it needs to be considered in terms of catalytic burner and cathode effects when oxidized and returned to that side of the fuel cell in the $\mathrm{CO}_{2}-$ recycle stream. 


\section{REFERENCES}

As this project developed, reference was made to numerous literature sources that were surveyed for relevant information. For simplicity and continuity, these accumulating references have been carried forward in each of our reports while further additions were also made to the list. Thus, the existing numerical sequence has been maintained throughout, independent of a need to site earlier references.

(1) "Monitoring Contaminants in Coal-Derived Gas for Molten Carbonate Fuel Cells," Final Report, prepared by TRW, Energy Engineering Division, for ANL, Contract No. 31-109-38-6108, May 1981.

(2) Gilbert/Commonwealth, Seventh Annual Gasification and Gas Stream Cleanup Systems Contractors Review Meeting, June 1987.

(3) General Electric Company; "Development of Molten Carbonate Fuel Cell. Power Plant, Final Report to DOE, Contract No. ACO280-ET17019, March 1985.

(4) Kunz, H.R. et al.; "Effects of Halides on the Performance of Coal-gas Fueled Molten Carbonate Fuel Cells, "International Fuel Cell Corporation" Final Report to DOE/METC, DOE/MC231362293.

(5) TRW (Energy Planning Division); "Coal Derived Fuel Gases for Molten Carbonate Fuel Cells", Report to DOE/METC-8085-T2.

(6) Park, S.M. and O'Brien, T.J.; "Effects of Several Trace Contaminants on Fuel Cell performance," University of New Mexico Report to DOE/METC/RI-80/16, (1980).

(7) Physical sciences, Inc.; "Interaction of Trace Species with the Molten Carbonate Fuel Cell," TR-192, November 1979.

(8) Viat, E.J. et al.; "Evaluation of Gasification and Cleanup Processes for use in MCFC Power Plants", Westinghouse 1983Final Report, DOE/MC16220-1306 (DE83003821).

(9) Pigeaud, A. and KIinger, J.; "Study of the Effects of Soot, Particulate and Other Contaminants on Molten Carbonate Fuel Cells Fueled by Coal Gas", Final Report by Energy Research Corporation for DOE/METC, DOE/MC21154-2269 (DE87001058), 1987.

(10) Eriksson, G.; Chemica Scripta, 8, p. 100 (1975), and Acta Chem. Scand., 25(7), p. 2651 (1971).

(11) PSI Technology Co.; "Transformations of Inorganic Coal Constituents in Combustion System", Quarterly Report No. 4 for. DOE Contract No. DE-AC22-86PC90751 (1987).

(12) Barin, I. and Knacke, 0.; "Thermochemical Properties of Inorganic Substances", 921 pages, Berlin, Springer-Verlag $(1973)$. 
(13) Barin, I., Knacke, O. \& Kubaschewski, O.; "Thermochemical Properties of Inorganic Substances", 861 pages Supplement, Berlin, Springer-Verlag (1977).

(14) JANAF Thermochemical Tables with supplements, 1141 pages, National. Bureau of standards of the U.S. Department of Commerce, Washington, D.C., 1971-1978.

(15) Appleby, A.J. and Nicholson, S.B.; "Reduction of Oxygen in Molten Lithium Carbonate," J. Electroanal. Chem., 53, p. 105 $(1974)$.

(16) Lu, S.H., and Selman, J.R.; "Electrode Kinetics of Fuel Oxidation" at Copper in Molten Carbonate," J. Electrochem. Soc., $131(12)$, p. 2827 (1984).

(17) Bard, A.J., and Faulkner, L.R.; "Electrochemical. Methods: Fundamental's and Applications," John-Wiley \& Sons, N.Y. $(1980)$.

(18) Vetter, K.J.; "Electrochemical Kinetics," Academic Press, New York (1967).

(19) Wilemski, G.; "Modeling of $\mathrm{H}_{2} \mathrm{~S}$ Effects on the Performance of Molten Carbonate Fuel Cells," Appendix A, "Effects of $\mathrm{H}_{2} \mathrm{~S}$ on Molten Carbonate Fuel Celis," Institute of Gas Technology, (1987) DOE/MC/2-212-2039 (DE86010431).

(20) Blander, M, and Yosim, S.J.; J. Chem. Phys. 39, p. 2610 $(1.963)$.

(21) Saboungi, M.L. and Blander, M.; J. Chem. Phys. 63, p. 212 $(1975)$.

(22) Sabourigi, M.L. and Blander, M.; J. Am. Ceram. Soc. 58, p. 1 $(1975)$.

(23) Pelton, A.D., Bale, C.W. and Lin, P.L.; "Calculation of Thermodynamic Equilibria in the Carbonate Fuel Cell", Ecole Polytechnique, Montreal, Canada; published in Can. J. Chem. 62 (3), p. 457 (1984).

(24) ibid.; CALPHAD $\underline{6}$ (4), p. 255 (1982).

(25) ibid.; CALPHAD $I$ (4), p. 295 (1983).

(26) ibid.; CALPHAD 8 (1), p. 95 (1984).

(27) ibid.; "Calculation of Thermodynamic Equilibria in the Carbonate Fuel CelI - Vol I and II," project No. CDT-P501, Final Report to DOE/ANL under Contract No. DE-AC02-79ET 15416 $(1981)$.

(2.8) Mills, K.C.; "Thermodynamic Data for Inorganic Sulphides, Selenides and Tellurides," Butterworths, London (1974). 
(29) The American Ceramic Society; "Phase Diagrams for Ceramists," Columbus, Ohio (1983).

(30) Wilemski, G. et al.; "Analytical and Numerical Research Associated with continued MCFC Model Development and Validation," 1986 Final Report by Physical Sciences, Inc. for DOE/ANL, PSI401/TR560, Contract No. 43052401.

(31) Lumsden, Y.; "Thermodynamics of Molten Salt Mixtures", Acadernic Press, London (1966).

(32) Chase, M.W. et. al.; "JANAF Thermochemical Tables", for National Bureau of Standards, 3 rd Edition in J. Phys. Chem. Ref. Data 14, Supplement No. 1 (1985).

(33) Robie, R.A. et al.; "Thermodynamic Properties of Minerals and Related Substances", U.S. Geological Survey, Bull. 1452, U.S. Gov't Printing office, Washington, DC (reprint with corrections, 1979 ).

(34) Elliot, J.F. and Gleiser, M.; "Thermochemistry for steel Making", Volume I, Addison-Wesley, Reading and London.

(35) Saboungi, M.I.; J. Chem. Phys. 73, p. 5800 (1980).

(36) Remick, R.J.; "Effects of $\mathrm{H}_{2} \mathrm{~S}$ on Molten Carbonate Fuel Cells", Final Report by Institute of Gas Technology to DOE/METC under Contract No. DE-AC21-83MC2021.2 (1986).

(37) Ham, D. and Gelb, A. et al.; "Hot-gas Cleanup for Molten Carbonate Fuel Cells: Dechlorination and Soot Formation", Physical Sciences, Inc., 1984 Final Report DOE/MC16242-1554 (DE84003072).

(38) Patel, P.S., et al.; "Trace Contaminant Removal from Hot Coalgas for MCFC Application", Energy Research Corp., 1985 Final Report to DOE/MC20094-2031 (DE86001072).

(39) Bloomfield, D. et al.; "Interaction of Trace Species with the Molten Carbonate Fuel Cells", Physical Sciences, Inc., Report to DOE/ANL, TR-192 (1979).

(40) Smith, S.W. and kunz, H.R.; "Effects of Sulfur on Molten Carbonate Fuel Cells - A Survey", Proc. of Symp. on Molten Carbonate Fuel Cell Technology 84-13, p. 246, Selman Claar eds., The Electrochemical Society Montreal Mtg. (1983).

(41) Smith, S.W. and Kapelner, S.M.; "The Equilibrium Constant for the Reaction $\mathrm{H}_{2} \mathrm{~S}+\mathrm{H}_{2} \mathrm{O}+(\mathrm{Li} / \mathrm{K}) \mathrm{CO}_{3} 4 \mathrm{H}_{2}+\mathrm{CO}_{2}+(\mathrm{Li} / \mathrm{K}) \mathrm{SO}_{4}=$," $\mathrm{J}$. Elkectrochem. Soc. 130 (2), p. 405 (1983).

(42) CRC Handbook of Chemistry and Physics, 61st ed., CRC Press, Boca Raton (1980).

(4.3) Pigeaud, A. et al.; "Development of MCFC Technology", Annual Report Nos. 15 (1979), 19 (1980) by Energy Research Corp. to DOE/ANL under Contract No. DE-AC03-76ET11304. 
(44) Farooque, N. et al.; "Development of Internal Reforming MCFC stack Technology", Monthly Progress Report Nos. 89-2, 89-5, 89-12 by Energy Research Corp. to DOE/METC under Contract No. DE-AC21-87MC23274.

(45) Pigeaud, A. et al.; "Effects of Coal-derived Trace Species on the Performance of Molten Carbonate Fuel Celis", Monthly Progress Report Nos. 7, 8, 9 (1989) by Rnergy Research Corp. to DOE/METC under Contract No. DE-AC21-88MC25009.

(46) ibid, ; Nos. 10/11 (1989).

(47) ibid.; Nos. $12 / 13$ (1989).

(48) ibid.; No. 14 (1989).

(49) Schmidt, D.K. et al.; "Fluidized Bed Coal Gasification with Hot-gas Cleanup", Proceedings 8th Annual Gasification and Gas Stream Cleanup Contractors Review, Vol 1, p. 32 (DE88010253).

(50) Wolf, T.L. and Wilemski, G., "Molten Carbonate Fuel Cell Performance Model," J. Electrochem. Soc. 130, p. 48 (1983).

(51) Wilemski, G., "Mathematical Modeling of Fuel Cell Electrodes, " Final Report, PSI TR-350, Physical Sciences, Inc., October 1982 .

(52) Wilemski, G., Kemp, N.H., and Gelb, A.; Molten Carbonate Fuel. Cell Performance-Model Update," Final Report, PSI TR-459 to DOE (DE85003356), Physical Sciences, Inc., January 1985.

(53) Dobbins, J.T.; "Semi-micro Qualitative Analysis", John Wiley and Sons, New York. 


\section{APPENDIX A}

MULTICOMPONENT COAL-GAS CONTAMINANT EQUILIBRIA

Concentrations in the Solid/Liquid/Gas Phases at $650^{\circ} \mathrm{C}$ and 1 Atm Pressure are Calculated for a Carbonate Fuel Cell Environment. by the modified SOLGASMIX (SGMCIS) Computer Program.

- Roman Numeral I Tables are equilibria only between fuel constituents and various gaseous contaminants, in the absence of fuel cell components such as electrolyte, electrode, etc.

- All Concentrations and Activities are given in mole fractions of the Gas Phase or the separate Anion/Cation Contents of the Liquid Melt.

- Nominal Coal-gas Constituent Composition in all cases $\begin{array}{llllllll}\text { was: } \quad 0.36 & \mathrm{H}_{2} / 0.20 & \mathrm{CO} / 0.18 & \mathrm{H}_{2} \mathrm{O} / 0.20 & \mathrm{CO}_{2} / 0.06 & \mathrm{~N}_{2} & \text { mole }\end{array}$ fraction of 1 atmosphere.

- Nominal Cation Composition of Fuel Cell Carbonate Electrolyte was: $0.62 \mathrm{Li}^{+} / 0.38 \mathrm{~K}^{+}$mole fraction. 
INDEX OF CONTAMINANTS STUDIED IN EACH OF THE FOLLOWING TABLES

\begin{tabular}{|c|c|c|c|c|c|c|c|c|c|c|}
\hline \multirow[b]{2}{*}{ TABLE 非 } & \multicolumn{10}{|c|}{ Max. Trace Species (ppm) Simul taneously Present } \\
\hline & $\underline{\mathrm{NH}}_{3}$ & $\underline{\mathrm{HCl}}$ & $\underline{\mathrm{H}}_{2} \mathrm{~S}$ & $\underline{\mathrm{H}}_{2} \underline{\mathrm{Se}}$ & As & $\underline{2 n}$ & $\underline{P b}$ & $\underline{\text { Cd }}$ & $\underline{\mathrm{H} g}$ & $\underline{\text { Sng }}$ \\
\hline \multicolumn{11}{|c|}{ in Coal-gas only } \\
\hline $\mathrm{I} \bullet 1$ & 54 & 10 & 5 & 4.7 & & & 2.55 & & & \\
\hline $1 \cdot 2$ & 54 & 10 & 5 & 5 & & & & & 30 & \\
\hline $1 \cdot 3$ & 54 & 10 & 4.9 & 3.9 & & & & & & $3.4 \mathrm{E}-06$ \\
\hline $1 \bullet 4$ & 54 & 10 & 4.9 & 5 & & 15 & & & & \\
\hline$I \cdot 5$ & 54 & 10 & 4.9 & 5 & & & & 10 & & \\
\hline$I \bullet 6$ & 54 & 5 & 5.1 & 5 & 0.45 & & & & & \\
\hline$I \bullet 7$ & 54 & - & - & - & 9969 & & & & & \\
\hline$I \bullet 8$ & 54 & - & - & - & 0.005 & & (including & solid & $\mathrm{Ni}(\mathrm{c})$ & present) \\
\hline \multicolumn{11}{|c|}{ Coal-gas + FC-components } \\
\hline$I I \bullet I$ & 54 & 3 & - & - & & & & & & \\
\hline $11 \cdot 2$ & 54 & - & 20 & - & & & & & & \\
\hline $\mathrm{II} \cdot 3$ & 54 & - & - & 3.4 & & & & & & \\
\hline II $\bullet 4$ & 54 & 0.01 & 20 & - & & & & & & \\
\hline$I X \cdot 5$ & 54 & 1.0 & 20 & - & & & & & & \\
\hline $11 \cdot 6$ & 54 & 3 & 1.0 & - & & & & & & \\
\hline$I I \bullet 7$ & 54 & - & - & 4.7 & & & 2.55 & & & \\
\hline$I I \bullet 8$ & 54 & - & - & 13 & & 15 & & & & \\
\hline $11 \bullet 9$ & 54 & - & - & 4 & & & & & & $3.4 \mathrm{E}-06$ \\
\hline$I I I \bullet I$ & 54 & - & - & - & & & 2.55 & & & \\
\hline$I I I \cdot 2$ & 54 & 0.01 & - & - & & & 2.55 & & & \\
\hline I II $\bullet 3$ & 54 & 1.0 & - & - & & & 2.55 & & & \\
\hline$I I I \cdot 4$ & 54 & - & 1.0 & - & & & 2.55 & & & \\
\hline $111 \cdot 5$ & 54 & - & - & - & & & & & & $7.8 \mathrm{E}-04$ \\
\hline $111 \cdot 6$ & 54 & - & - & - & & (including & also solid & $\mathrm{Ni}(\mathrm{c}))$ & & $3.4 \mathrm{E}-06$ \\
\hline $111 \cdot 7$ & 54 & 1.0 &.- & - & & & & & & $7.8 \mathrm{E}-04$ \\
\hline$I I I \bullet 8$ & 54 & - & 5 & - & & & & & & $7.8 \mathrm{E}-04$ \\
\hline$I V \cdot 1$ & 54 & - & - & - & & 20 & & & & \\
\hline$I V \cdot 2$ & 54 & 0.01 & - & - & & 20 & & & & \\
\hline IV $\cdot 3$ & 54 & 1.0 & - & - & & 20 & & & & \\
\hline IV.4 & 54 & - & 1.0 & - & & 20 & & & & \\
\hline $1 V \cdot 5$ & 54 & - & - & - & & & & 20 & & \\
\hline $1 V \cdot 6$ & 54 & 0.01 & - & - & & & & 20 & & \\
\hline $\mathrm{IV} \cdot 7$ & 54 & 1.0 & - & - & & & & 20 & & \\
\hline$I V \cdot 8$ & 54 & - & 1.0 & - & & & & 20 & & \\
\hline$I V \cdot 9$ & 54 & - & - & - & & & & & 30 & \\
\hline IV $\cdot 10$ & 54 & 0.01 & - & - & & & & & 30 & \\
\hline IV $\bullet 11$ & 54 & 1.0 & - & - & & & & & 30 & \\
\hline IV 12 & 54 & - & 1.0 & - & & & & & 30 & \\
\hline
\end{tabular}




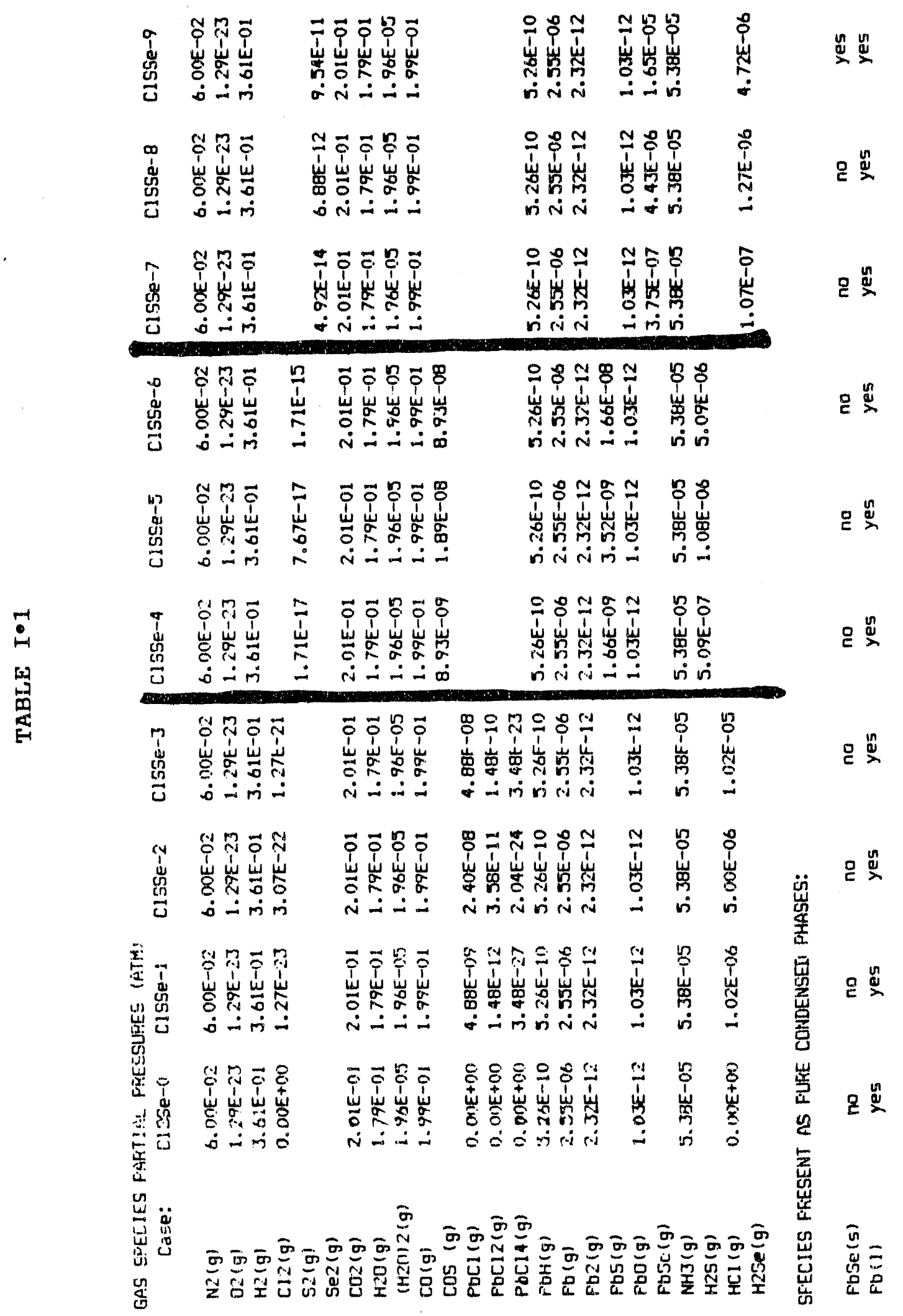




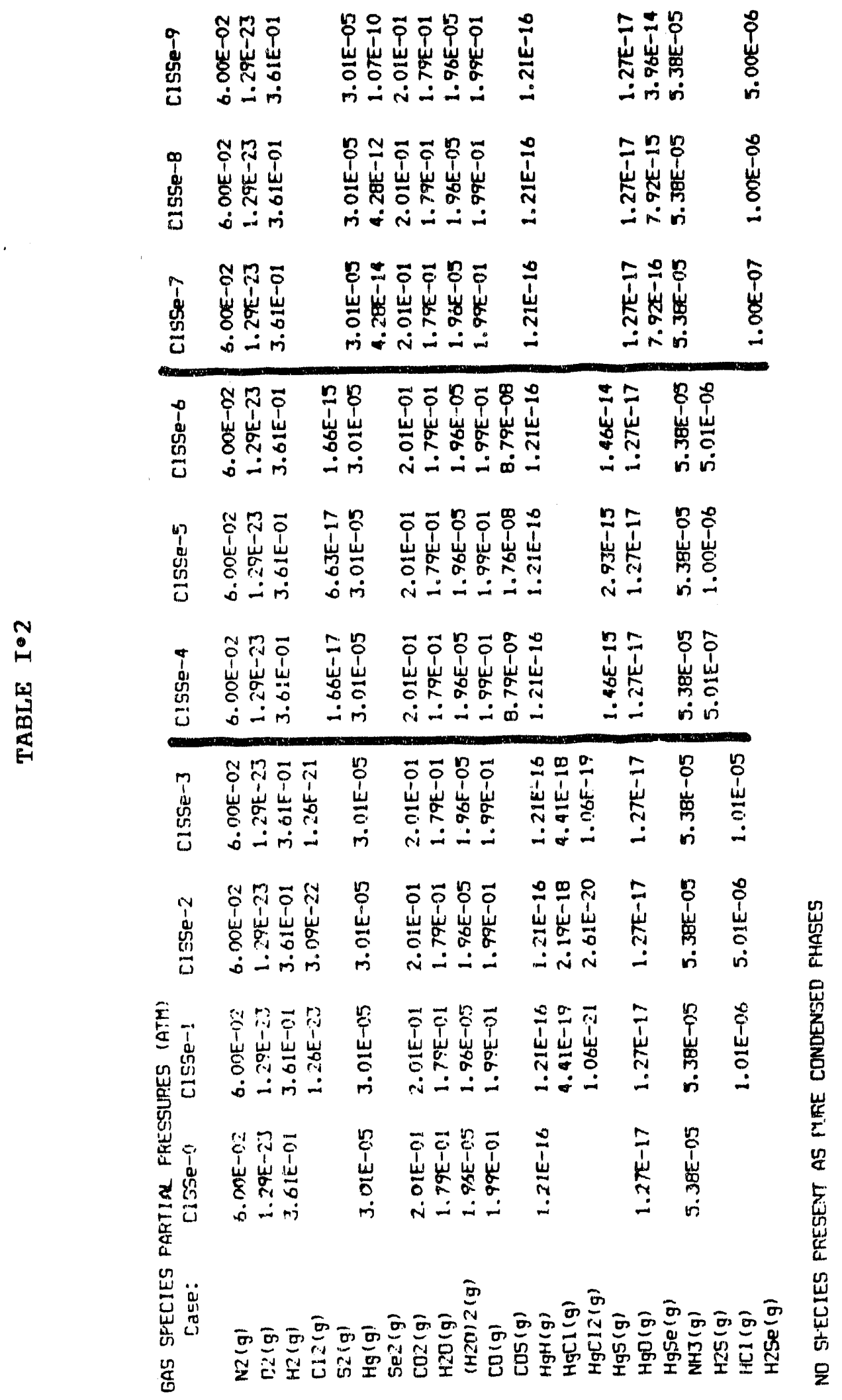




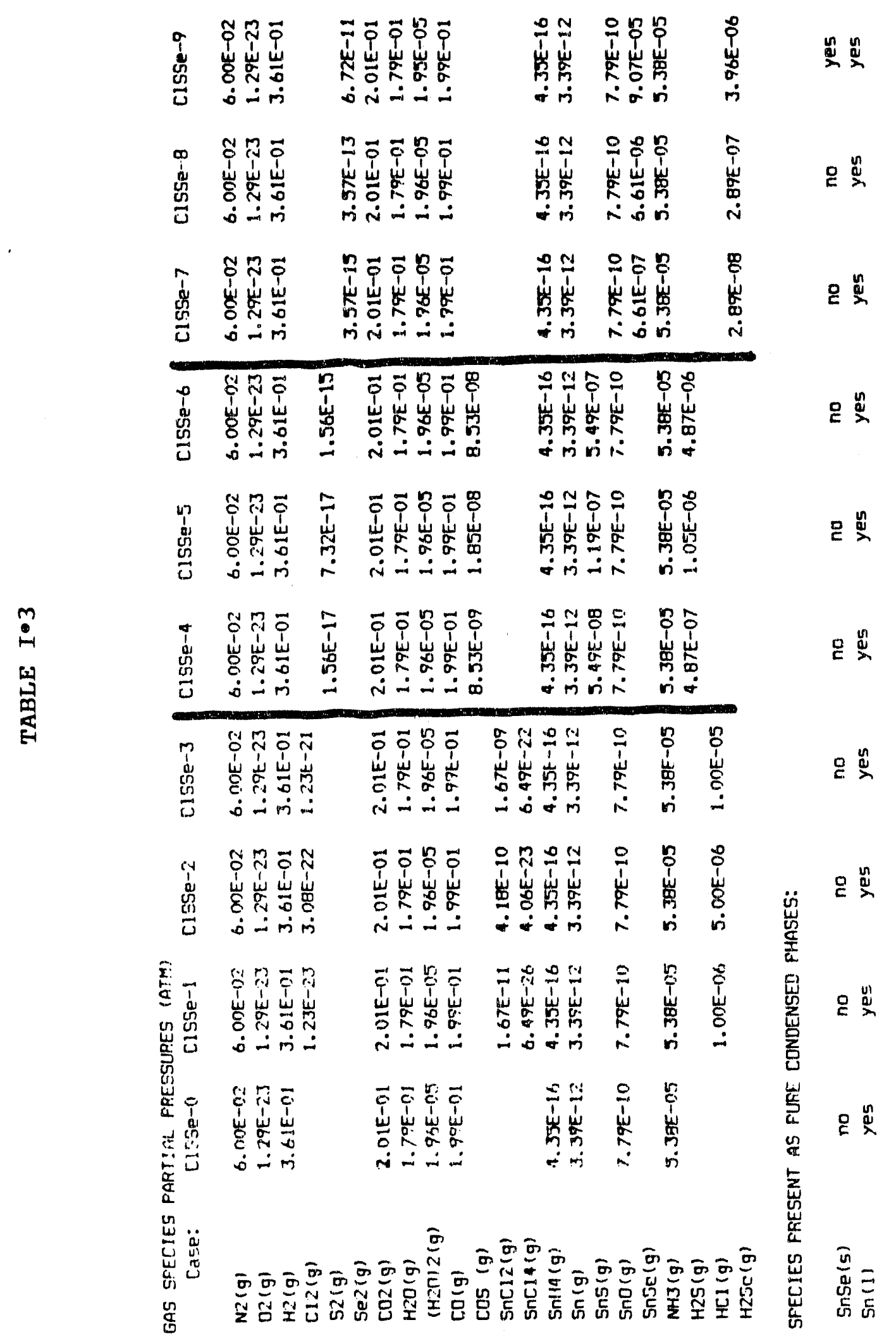




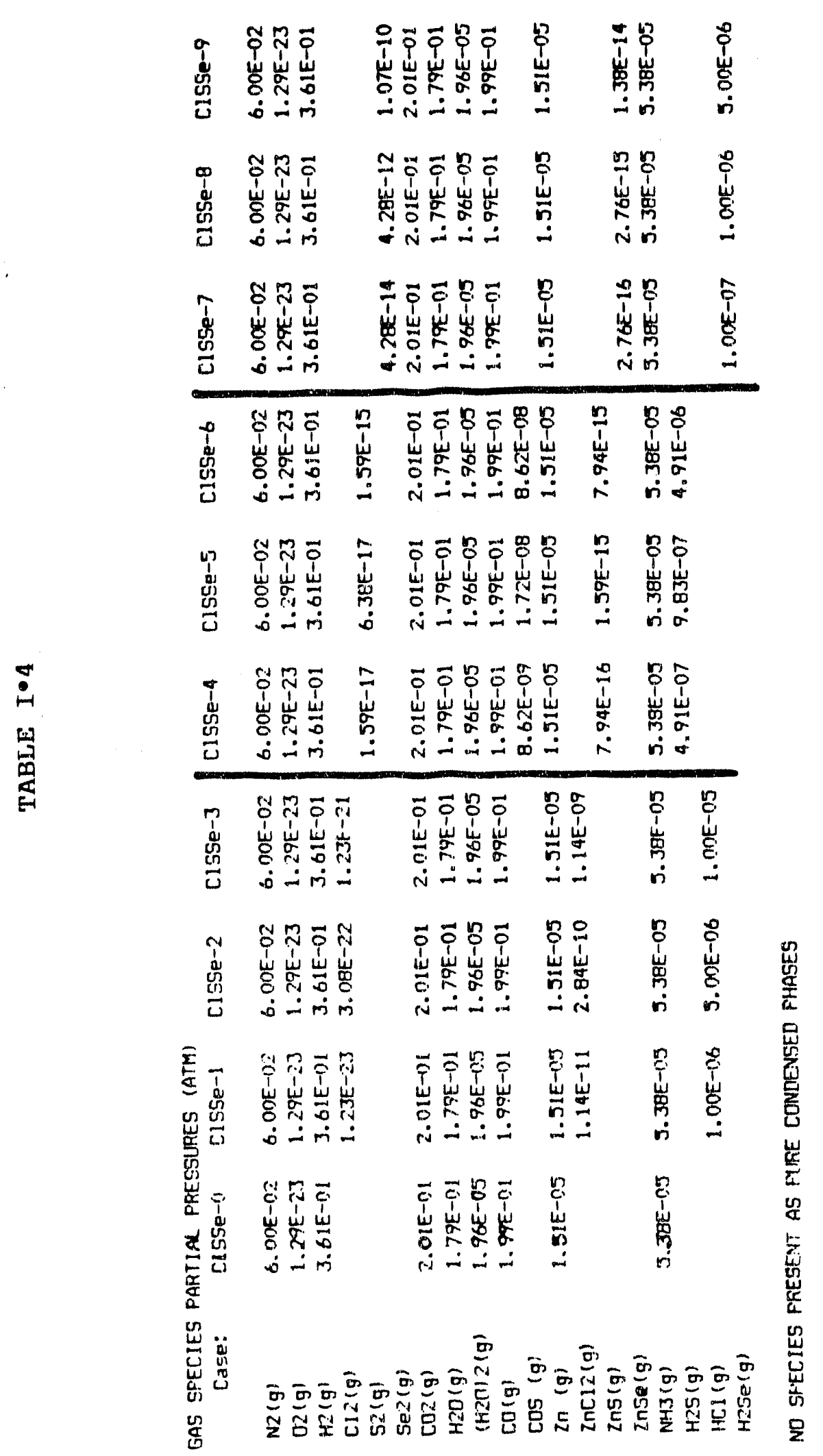




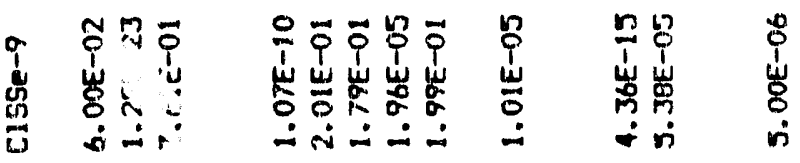

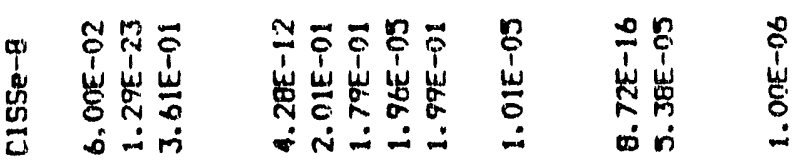

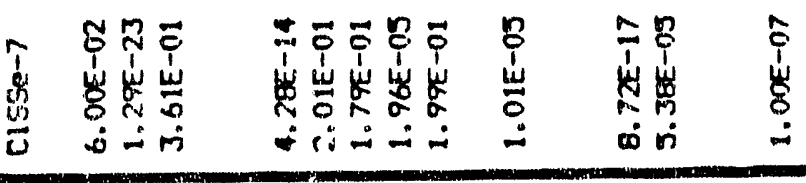

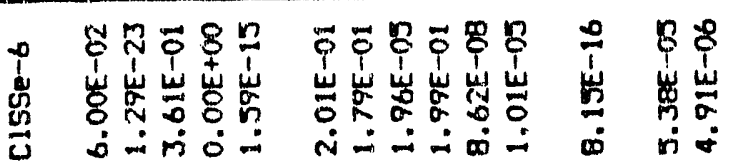

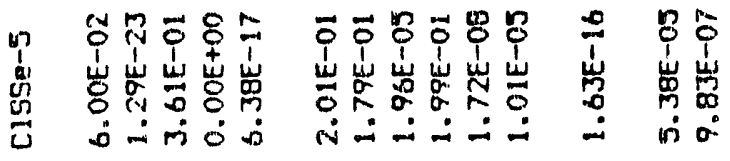

总

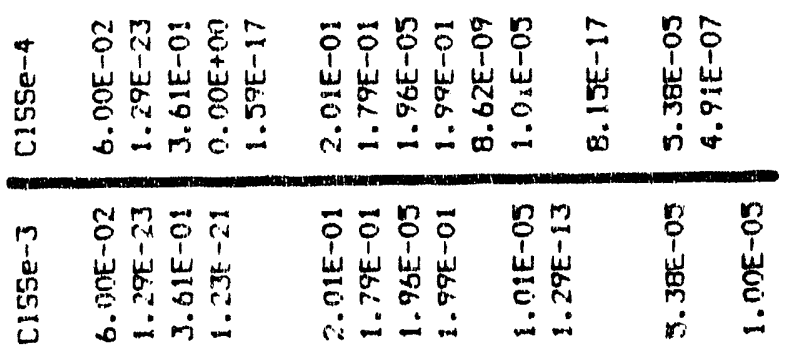

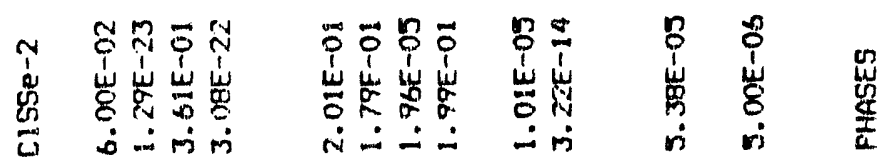

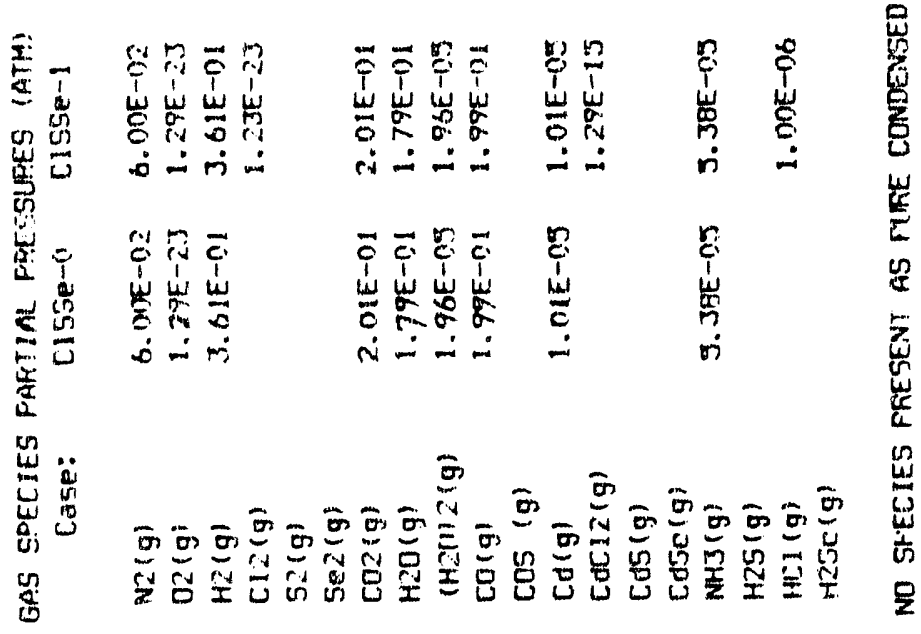




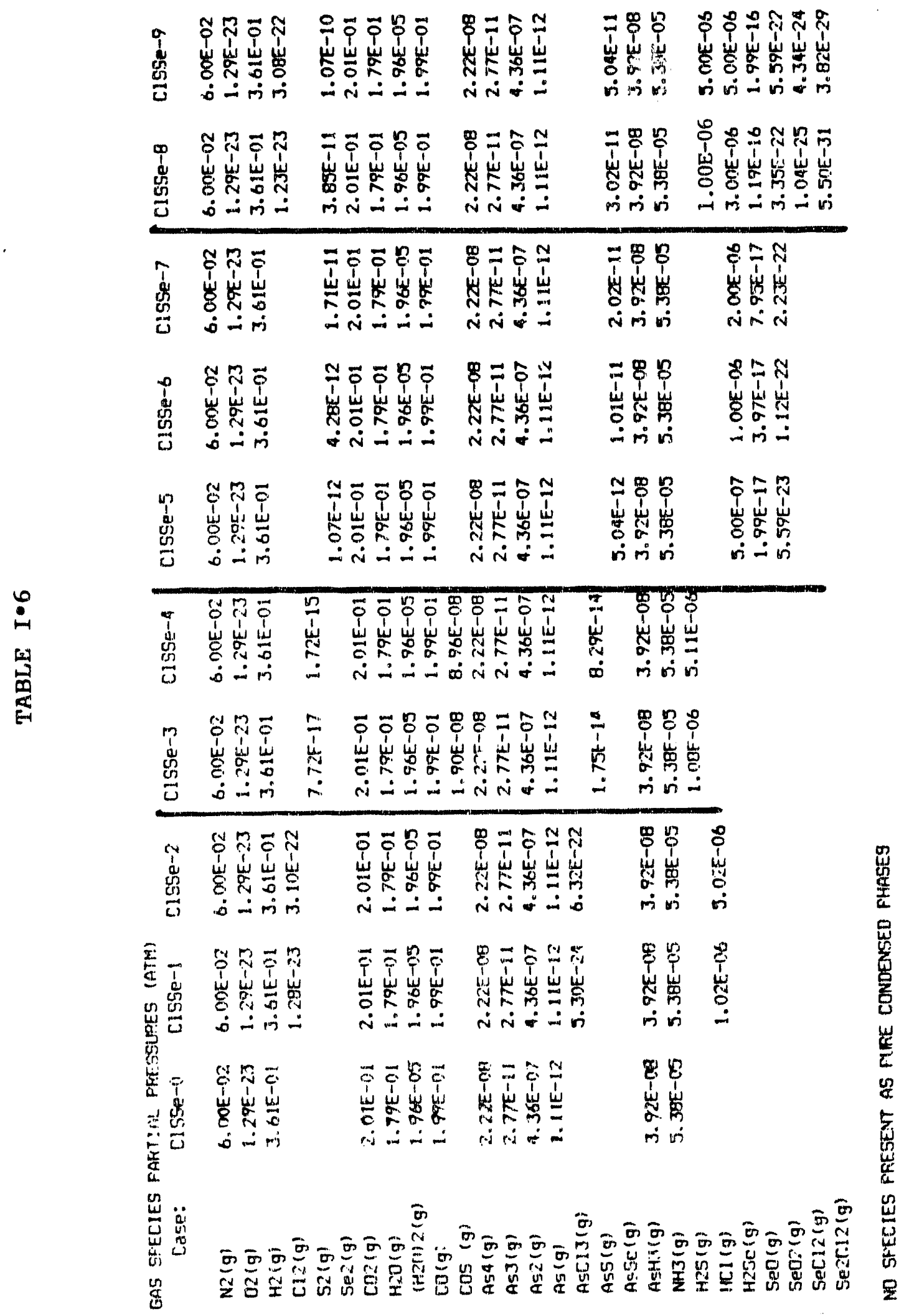




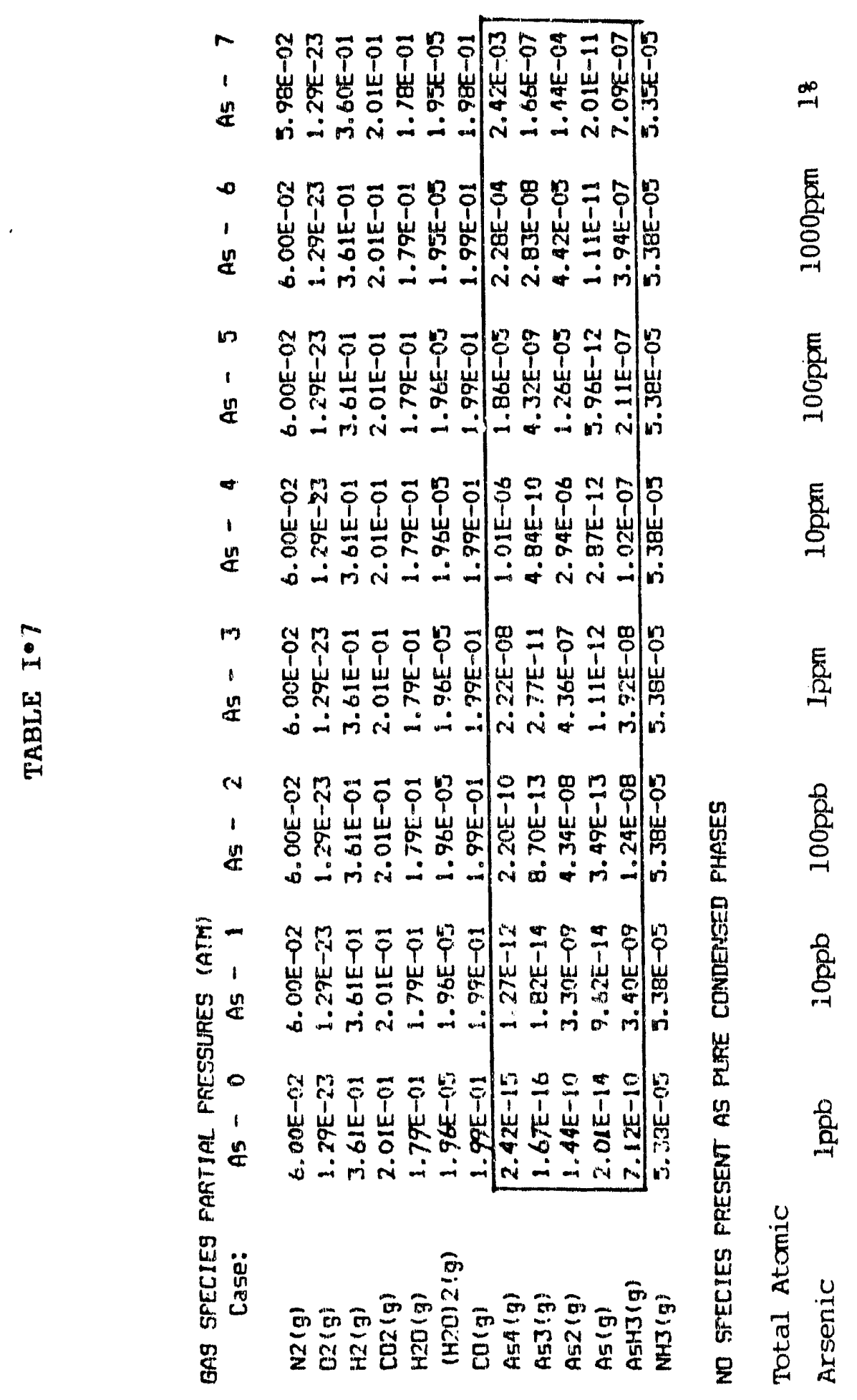




\section{TABLE $\mathrm{I} \bullet 8$}

GAS SFECIES FAFTIAL FRESSURES (ATM)

$$
\text { CASE: AS } \quad 0 \quad \text { AS }-1 \text { AE - } 2 \text { AS - } 3
$$

$\begin{array}{lllll}N 2(g) & 6.00 E-012 & 6.00 E-02 & 6.00 E-02 & 6.00 E-02 \\ 02(g) & 1.29 E-23 & 1.29 E-23 & 1.29 E-23 & 1.29 E-23 \\ H 2(g) & 3.61 E-01 & 3.61 E-01 & 3.61 E-01 & 3.61 E-01 \\ A 54(g) & 2.42 E-15 & 3.88 E-14 & 2.26 E-13 & 2.45 E-134 \\ A 53(g) & 1.67 E-16 & 1.82 E-15 & 5.00 E-15 & 5.32 E-154 \\ A 52(g) & 1.44 E-10 & 7.10 E-10 & 1.39 E-09 & 1.45 E-09+ \\ A 5(g) & 2.01 E-14 & 4.47 E-14 & 6.26 E-14 & 6.38 E-144 \\ C O 2(g) & 2.01 E-01 & 2.01 E-01 & 2.01 E-01 & 2.01 E-01 \\ H 20(g) & 1.79 E-01 & 1.79 E-01 & 1.79 E-01 & 1.79 E-01 \\ (H 20) 2(g) & 1.96 F-05 & 1.96 E-05 & 1.96 E-05 & 1.96 E-05 \\ C D(g) & 1.99 E-01 & 1.99 E-01 & 1.99 E-01 & 1.99 E-01 \\ N H 3(g) & 5.38 E-05 & 5.38 E-05 & 5.38 E-05 & 5.38 E-05 \\ A 5 H 3(g) & 7.12 E-10 & 1.58 E-09 & 2.21 E-09 & 2.26 E-094\end{array}$

SPECIES PFESENT AB PUKE CONDENSEI! PHASES:

$\begin{array}{lllll}N i A s(s) & \text { r:o } & \text { no } & \text { no } & \text { yes } \\ N 1(c r) & y e s & \text { yes } & \text { yes } & \text { yes }\end{array}$


A SAS SFECIEg PARTIAL PRLSSLRES (ATM: Case: HCl - $0 \mathrm{HCl}$ - 1

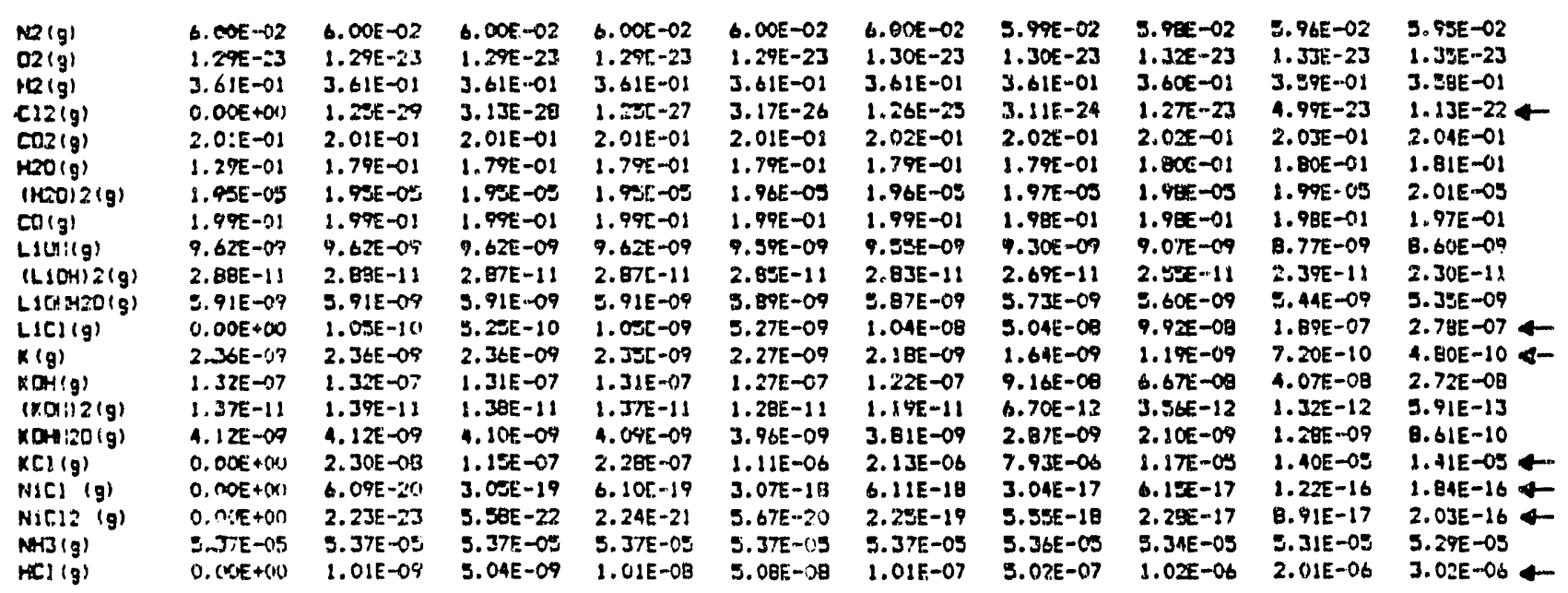

B EFECT AF HCI ON ELECTROYYE ACTIVITIES OF RESUIIED LZQUID V:OLZCULAR SPECZES DISSOLVISD IN MELT

\begin{tabular}{|c|c|c|c|c|c|c|c|c|c|c|}
\hline$(2 \pi 03(1)$ & $2.37 E-01$ & $2.37 E-01$ & $2.37 E-01$ & $2.37 \mathrm{E}=01$ & $2.3: E-01$ & $2.34 E-01$ & $2.20 E-01$ & $2.11 E-01$ & 1.97E-OS & $1.89 E-01$ \\
\hline$H(1)$ & 9. LSE-0.3 & $.15 E-03$ & 9. 15E-03 & $9.13 t-03$ & $9.12 E-03$ & $9.0 E E-03$ & & & & \\
\hline $101(1)$ & $0.00 E+00$ & $3.07 E-06$ & 1. 53E-05 & $3.07 t=05$ & $1.54 E-04$ & 3. OSE-04 & $1.47 E-03$ & $2.90 E-03$ & 5. $52 E-03$ & $0.12 E-03$ \\
\hline 111$)$ & 1. 18E-06 & $1.18 E-06$ & 1. 18E-0b & $1.17 t-06$ & $1.17 E-06$ & $1.16 E-06$ & $1.10 E-a b$ & $1.04 E-$ & $9.6 \mathrm{eE}-07$ & $9.27 E-07$ \\
\hline $12 \cos (1)$ & $7 .+4 E-02$ & $7.43 E-(1) 2$ & $7.38 E-02$ & $7.32 F-02$ & 6. B7E-02 & 0.36 & $3.59 E-02$ & $1.91 E-02$ & $7.02 E-03$ & $3.26 E-03$ \\
\hline $10+11)$ & 5. $3 S E-O A$ & 5. $86 E-04$ & $5.84 E=04$ & $5,825-04$ & $3 E-04$ & & $7 E-04$ & $2.9 \pi=04$ & $1.81 E-04$ & -024 \\
\hline$C 1(1)$ & $0.00 E+\alpha 1$ & $9.64 E-04$ & 4. $01 E-03$ & $9.586-03$ & $4.67 E-02$ & 02 & $3.33 E-01$ & $4.90 E-01$ & $87 E-01$ & -010 \\
\hline $20(1)$ & 1. $39 E-15$ & $1.3 \%-15$ & 1. 39E- 15 & 1. $37 t-15$ & 1.29E-15 & 1.19E-15 & $6.70 E-16$ & $x-16$ & $E-16$ & $35 E-17$ \\
\hline $1(\cos (1)$ & 2. $16 E-09$ & $2.16 E-09$ & 2. $16 E-09$ & $2.16 F-09$ & 2.165 .09 & $2.17 E-09$ & 2. $18 E-\infty 9$ & 2. $17 E-09$ & $2.22 E-09$ & $2.24 E-09$ \\
\hline $\mathrm{Ni}(\mathrm{OH}) 2(\$)$ & $3.30 E-00$ & 3. 3CE-C8 & $3.30 E-08$ & 3. 30E-08 & 3. $30 E-O B$ & $3.30 E-08$ & $3.32 E-08$ & $3.35 x-08$ & 3. 3EE-OB & $3.41 E-08$ \\
\hline NICla (1) & $0.00 E+001$ & $2.04 E-21$ & 5. $10 E-20$ & $2.04 E-19$ & 3. $16 E-18$ & $2.05 E-17$ & $5.07 E-16$ & $2.06=-15$ & Q. $14 E-15$ & $1.85 E-144$ \\
\hline $110(1)$ & 5. 18E-0.5 & 9. $18 E-\infty 5$ & 5. 18E-0S & 5. $18 E-O S$ & $5.18 E-03$ & $5.18 E-05$ & $5.20 E-05$ & $9.2 x=-05$ & 5. 2tE- OS & $5.28 E-05$ \\
\hline
\end{tabular}

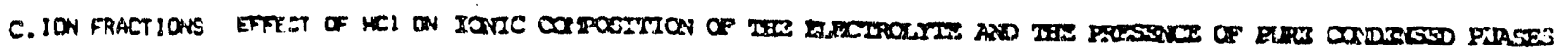

\begin{tabular}{|c|c|c|c|c|c|c|c|c|c|c|}
\hline Lit & 6. 2CE=01 & $6.20 E-01$ & $6.20 E-01$ & 6. 20E-01 & $6.20 E-01$ & $6.20 E-01$ & $6.20 E-01$ & $6.20 E-01$ & $0.20 E-01$ & $0.20 E-01$ \\
\hline$k+$ & 3. 81E-01 & 3. $\theta 0 E-01$ & 3. BDE-01 & $3.80 E-01$ & $3.80 E-01$ & $3.80 E-01$ & $3.60 E-01$ & 3. $80 E-01$ & 3. BOE-01 & 3. BOE -01 \\
\hline$N_{2} \oplus 2$ & $1.41 E-\infty$ & $1.41 E-09$ & 4. A4E-09 & 4. $17 E-09$ & 4.75E-09 & $3.105-09$ & $8.50 E-09$ & 1. $44 E-08$ & $3.095-00$ & 5. $16 E=0 B$ \\
\hline $007 x$ & $9.80 E-01$ & 9. BEE-UI & $9.87 E-01$ & $9.86 F-01$ & $9.79 E-01$ & $9.70 E-01$ & $9.05 E-01$ & Q. $36 E-02$ & $7.36 E^{\prime}-01$ & $6.595-01$ \\
\hline DH+ & 1. $18 E-02$ & $1.1 B E-O 2$ & $1.18 E-02$ & $1.18 E-02$ & 1.19E-02 & 1. $19 E-02$ & $1.22 E-O 2$ & $1.26 E-02$ & $1.32 E-02$ & $8.37 E-02$ \\
\hline Clar & $0.1 \times x+\infty$ & 1. $8 B E-D 4$ & $9.38 E-04$ & 1. $88 E-03$ & $9.34 E-0]$ & $1.84 E-02$ & $8.29 E-02$ & $1.51 E=01$ & $2.51 E-01$ & $3.27 E-01+$ \\
\hline $0=$ & 7. $17 E-\infty$ & $7.17 E-\infty 3$ & $7.18 E-08$ & $7.10 E-08$ & $7.2 \mathrm{AE}-0 \theta$ & $7.35 E-08$ & $0.04 E-\infty$ & $8.90 E-08$ & 1 1. OSE -07 & $1.19 E-07$ \\
\hline
\end{tabular}

SPECIES PRESENY AS PUNE CONOENSED PHASES:

Nitcr) yes yes yos yes yos yew yes yes yes yes 
TABLE II 2

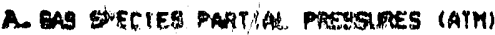

\begin{tabular}{|c|c|c|c|c|c|c|c|c|c|c|}
\hline Casin. & $425-0$ & M2S - 1 & Hes - & $129-$ & 125 - & 125 - & $125=6$ & Nes - & H2S -8 & H2S - \\
\hline $\lg \mid$ & $\Delta, 00=02$ & 6. $.00 E-02$ & $6.00 E-02$ & $6.00 \varepsilon-02$ & 6. $00 \mathrm{E}-02$ & $0.00 E-02$ & $1.00 E-02$ & $0.00 E=02$ & $6.00 E-02$ & 6.00E-02 \\
\hline (g) & $1.29 \%$ & $1.29 E-23$ & $1.29 E-20$ & $1.29 E-2 J$ & 1.29E-23 & $1.29 E-23$ & $1.29 E-23$ & $1.29 E-23$ & $1.29 E-23$ & $1.29 E-23$ \\
\hline$(g)$ & $3.61 \mathrm{E}-01$ & J. SIE-Ot & $3.61 E-01$ & $3.61 E-01$ & 3. $.1 E=01$ & $3.61 E-01$ & $3.61 E-01$ & $3.61 E-01$ & 3. $615-01$ & $3.61 E=01$ \\
\hline$(g)$ & $0.00 E+\infty 0$ & $1.65 E-19$ & 7. $575-19$ & $1.65 \pi-17$ & $7.59 E-17$ & $2.64 E-16$ & $1.65 E-15$ & $7.5 \% E-15$ & $1.57 \mathrm{E}-14$ & $2.64 E-14$ \\
\hline $\cos (g)$ & $2.01 E-01$ & $2.01 E-01$ & $2.01 E-01$ & 2. OSE -01 & 2.01E-O1 & $2.01 E-01$ & $2.01 E-01$ & $2.01 E-01$ & 2. O1E-01 & $2.01 E-01$ \\
\hline $\mathrm{N}=\mathrm{O}(\mathrm{g})$ & $1.79 E-0 \mathrm{~s}$ & 1. $79 E-01$ & $1.79 E-01$ & 1. 79t -01 & $1.79 E-01$ & $1.79 E-01$ & $1.79 E-01$ & $1.790-01$ & $1.79 E-01$ & 1. $78 E-01$ \\
\hline$(40.012(g)$ & $1.955-05$ & $1.95 E-05$ & 1. 9xE-Os & 1. $95[-05$ & $1.75 E-05$ & $1.95 x-0$. & 1.75E- 63 & $1.92 \leq-093$ & $1.95 x-05$ & $1.99 E-05$ \\
\hline$D(g)$ & S. PFE-01 & 1. $9 \% E-01$ & 1. $99 E-01$ & 1. 99E-01 & $1.79 E-01$ & $1.99 E-21$ & $1.94 E-01$ & 1. PQE 01 & 1. PQE-01 & $1.99 E-01$ \\
\hline Lloi(g) & $9.6 x z-09$ & $9.62 E-09$ & $9.625-09$ & 9. $\Delta x=-\infty 9$ & $9.62 E-109$ & $9.622-04$ & $9.62 E-\infty 9$ & $9.62 E-09$ & $9.62 \varepsilon-09$ & $9.62 E-09$ \\
\hline$(L 1 O+1) 2(g)$ & 2. $00 E-11$ & 2. $80 E-11$ & 2. $80 E-11$ & 2. BEE-11 & 2. $885-11$ & $2.8 B E-11$ & 2. $87 E-11$ & 2. $87 E-11$ & 2. $87 \mathrm{E}-11$ & $2.87 E-11$ \\
\hline $110 \times 20(g)$ & 5. $91 E-09$ & $3.91 E-19$ & $5.91 E-09$ & $5.91 E-09$ & $5.91 E-09$ & $5.91 E-09$ & $3.91 E-09$ & $5.91 E-09$ & $9.91 E-09$ & $5.91 E-09$ \\
\hline$|g\rangle$ & $2.36 E-09$ & 2. $36 E-04$ & $2.36 E-64$ & 2. 36E-09 & 2. $36 E-09$ & $2.36 E-09$ & 2.36E-09 & $2.3 A E-09$ & $2.36 E-09$ & $2.36 E-09$ \\
\hline $\operatorname{xan}(g)$ & $1 . \pm 2 E-\infty 7$ & 1. $32 x-07$ & 1. $32 E-07$ & $1.32 \mathrm{x}-07$ & $1,32 E-07$ & $1.32 E-07$ & $1.32 t-07$ & $1.3 x=-07$ & 1. 32E -07 & $1.32 E-07$ \\
\hline$(\mathrm{MOH}) \bar{z}(g)$ & $1.39 E-11$ & 1. उ9E-1! & 1. J9E- 11 & 1. JOE-11 & $1.34 E-11$ & 1.39E-11 & $1.39 E-11$ & 1.3\%E-11 & 1. 3QE-11 & 1. 37E:-11 \\
\hline $420(9)$ & 4. $12 E-\infty$ & 4. $12 \mathrm{EE}-09$ & $4.12 E-\infty 9$ & $4.12 E-09$ & $4.125-09$ & $4.124=00$ & $4.12 E-09$ & $4.12 x-09$ & $4.12 E-09$ & 4.12E-09 \\
\hline$(g)$ & $0.00 E+\infty$ & $0.76 E-10$ & 1. B8E -09 & 8. $76 E-09$ & 1. BBE-OB & $3.51 E-00$ & $8.76 E-00$ & $1,07=-07$ & 2. $71 E-07$ & J. $51 E-07$ \\
\hline $3(9)$ & $5.3 \pi E-\infty 5$ & 5. 37E- & $\therefore .37 E-0 \%$ & 3. $37 E-\infty$ & 5. $37 \varepsilon-05$ & $5.37 E-05$ & $3.3 T E-05$ & 5. 37E-OW & 5. 37E-05 & 5.37E-0.5 \\
\hline 5 (9) & $0.00 E+00$ & $5.00 E-00$ & 1.07E-Q7 & $5.00 E-07$ & $1.07 E-06$ & $2.00 E-0 b$ & $5.00 E-06$ & $1.87 E-05$ & $1.54 E-05$ & $2.00 E-05$ \\
\hline
\end{tabular}

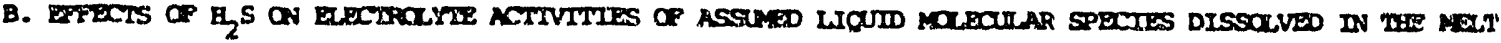

\begin{tabular}{|c|c|c|c|c|c|c|c|c|c|c|}
\hline $\begin{array}{l}\operatorname{Li2} 203(1) \\
\operatorname{LiON}(1)\end{array}$ & $\begin{array}{l}2.3 \pi E-01 \\
9.15 E-03\end{array}$ & $\begin{array}{l}2.37 E-01 \\
9.15 E-03\end{array}$ & $\begin{array}{l}\text { 2. J7E-01 } \\
9.15 x-03\end{array}$ & $\begin{array}{l}2.37 E=01 \\
9.15 E-03\end{array}$ & $\begin{array}{l}2.5 T E-01 \\
9.15 E-03\end{array}$ & $\begin{array}{l}2.37 E-01 \\
9.15 E-03\end{array}$ & $\begin{array}{l}2.37 E-01 \\
9.15 E-03\end{array}$ & $\begin{array}{l}2.37 E-01 \\
9.15 E-0.3\end{array}$ & $\begin{array}{l}2.37 E-01 \\
9.15 E-03\end{array}$ & $\begin{array}{l}2.37 E-01 \\
9.15 E-03\end{array}$ \\
\hline $125(1)$ & $0.000+\infty$ & 1. BSE -07 & $3.9 \pi E-07$ & $1.85 E-06$ & $3.97 E-06$ & $7.90 E-06$ & $1.85 E-05$ & $3.9 \pi-0 s$ & $9.72 E-0.5$ & $7.40 E-05$ \\
\hline izn(1) & $18 E-06$ & $18 E-06$ & 1.1BE-06 & $1.18 E-06$ & - 18E-06 & $1.18 E-06$ & $1.1 B E-06$ & $1,1 E E-06$ & $1.18 E-06$ & -06 \\
\hline i XxOA 1 & $.00 E+00$ & 2. 40E-15 & 3. $15 E-15$ & 2.40 & 5. $15 E-14$ & $9.60 E-14$ & 2. $40 E-13$ & $5.14 E-13$ & $7.41 E-13$ & \\
\hline$(2 \cos (1)$ & - 44E-02 & $7.44 E-02$ & $7.44 E-02$ & $7.44 E-02$ & $7.44 E-02$ & $7.44 E-02$ & $7.44 E-02$ & $7.14 E-02$ & $7.4] E-02$ & $7.43 E-02$ \\
\hline $\mathrm{OH}(1)$ & 5.86E-04 & $3.86 E-04$ & 5. 86E-OA & 5. $86 E-04$ & 3.86E-04 & 5. B6E-O4 & 5. B6E-04 & 5. $36 E-04$ & 5. 86E-04 & 5.66E-01 \\
\hline $225(1)$ & $0.00 E+\infty 0$ & $6.72 E-09$ & 1. $44 E-08$ & $6.72 E-09$ & $1.44 E-07$ & PE-07 & $6,72 x-07$ & $1.44 E-06$ & 2. OQE -06 & 2.69 \\
\hline 20111 & $.39 E-15$ & $1.39 E-15$ & $1.39 E-15$ & 1. $39 E-15$ & $1.34 E-15$ & $9 E-13$ & 1.39E- 15 & 1. $3 \% E-15$ & $1.39 E$ & 1.39 \\
\hline $2504(1)$ & $0.00 E \&(0)$ & $8.02 E-13$ & $1.72 E-12$ & $8.02 E-12$ & $1.72 E-11$ & $3.21 \mathrm{E}-11$ & $0.02 \pm-11$ & $1.72 x-10$ & $2.48 E-10$ & \\
\hline$v_{1} \cos (1)$ & $2.16 E-64$ & $2.16 E-09$ & 2.16E-09 & $2,165-09$ & $2.16 E-09$ & 2. $16 E-09$ & 2. $16 E-09$ & 2. $16 x-09$ & 2. $16 E-09$ & $2.16 E-09$ \\
\hline $11(\mathrm{OH}) 2 \mathrm{is})$ & $3.30 \div-\infty 9$ & J. $30 E-08$ & 3. 30E -08 & $3.308=08$ & $3.30 E-08$ & J. $30<-08$ & $3.30 E \cdot 00$ & 3. 30E-OB & $3.30 E-09$ & 3. 30E-08 \\
\hline Nis(l) & $0.00 E+D i)$ & $2.07 E-06$ & 4. 43E-06 & $2.07 E-05$ & 4. 43E-OS & $9.27 E-0.5$ & $2.07 E-104$ & $4.4 x E=04$ & $6.39[-04$ & 0. 27E-.04 \\
\hline Nic!ll & 5. IEE-OS & 5. 18E-Crs & 5. 12E-05 & 5. 19E-OS & $5.18 E-O 5$ & $5.16 E-O S$ & $5.18 E-05$ & 3. 1 ex-0s & 5. $18 E-05$ & 5. 18E-05 \\
\hline visol(s) & $0.00 E+00$ & $4.22 \mathrm{E}-25$ & $9.04 E-25$ & 1. $.22 E-24$ & $9.04 E-24$ & $1.69 t-23$ & $4.22 E-23$ & $9.04 E-23$ & 1. 30E-22 & $1.69 E-22$ \\
\hline
\end{tabular}

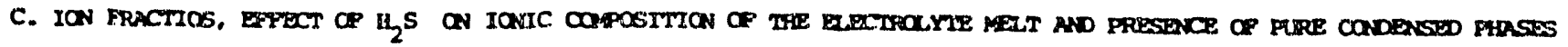

\begin{tabular}{|c|c|c|c|c|c|c|c|c|c|c|}
\hline $\mathrm{Lt}$ & $0.20 \epsilon-01$ & 4. $20 E-01$ & $6.20 E-01$ & 6. 20E-01 & $6.20 E-01$ & b. $Z 0 E-01$ & 6. $20 E-01$ & $6.20 E-01$ & $0.20 E-01$ & $0.20 E=01$ \\
\hline$x+$ & 3.80E-01 & 3. QOE $=01$ & 3. BOE-O1 & 3. & $3.00 f+101$ & 3 $B O E-O 1$ & 3. $80 E-01$ & 3. BOE-OI & 3. $\theta 0 E-0 t$ & $3.00 E-01$ \\
\hline$M I+2$ & $4.41 E-09$ & $4.41 E-09$ & $4.41 E-09$ & 4. $41 E-09$ & $9.415 .-104$ & $4.41 E-09$ & $4.41 E-\infty$ & $4.92 E-09$ & $0.43 \pm-69$ & $4.44 E-09$ \\
\hline $\mathrm{COJ}=$ & $9.89 \mathrm{E}-01$ & $4,88 E-01$ & $9.88 E-01$ & $9.88 E-01$ & 9. & 9. 1SQE-O1 & $9.86 E-01$ & 9. $B E E-01$ & $9.88 E-01$ & 9. BSE-OI \\
\hline ot & 1. $1 E E-02$ & $1.18 E-02$ & 1. $18 E-02$ & $1.3 \& E-02$ & $1.1 e^{*}=02$ & $1,1 \mathrm{BE}-02$ & 1.1BE-02 & $1.18 E-02$ & $1.18 E-02$ & $1.19 E-02$ \\
\hline 8- & $0.00 E+\infty$ & $2.07 E-07$ & $4.455-07$ & $2.07 t-06$ & 4. 4. & $4.30 E-06$ & $2.07 t-05$ & $4.45 x-05$ & $6.41 E-05$ & e. JoE-os \\
\hline $\begin{array}{l}0= \\
\operatorname{son}=\end{array}$ & $\begin{array}{l}7.1 \pi-00 \\
0.00 E: 00\end{array}$ & 7. $17 E-0 B$ & $\begin{array}{l}7.17 E-08 \\
1.41 E-12\end{array}$ & $\begin{array}{l}7.17 k-08 \\
\text { o. } 58 E-12\end{array}$ & $\begin{array}{l}7.17 E-08 \\
1.41 E-11\end{array}$ & $\begin{array}{l}7.17 E-0 B \\
2.63 E-18\end{array}$ & $7.17 E-\infty 8$ & $\begin{array}{l}7.17 E-00 \\
1.0-10\end{array}$ & $\begin{array}{l}7.17 E-08 \\
2.075-10\end{array}$ & $\begin{array}{l}7.16 E-00 \\
2.67 E-10\end{array}$ \\
\hline
\end{tabular}

SFECIES PRESERT AS PUSS. CDNOENSED PHASES:

NIl(t, ) yes yes yes yes yas yes yes yes yos yes 
TABLE II 3

A. gas sfecieg partial presslates (ATM)

Cese: Se - 0 se -

\begin{tabular}{|c|c|c|}
\hline$N 2(g)$ & $0.00 \varepsilon-02$ & $0.00 E-02$ \\
\hline $02(g)$ & $1.29 E-23$ & $1.29 E-23$ \\
\hline $\mathrm{H} 2(\mathrm{~g})$ & $3.61 E-01$ & J.6IE-01 \\
\hline $\operatorname{se} 2(g)$ & $0.00 E+\infty$ & $3.025-14$ \\
\hline $\cos (g)$ & $2.01 E-01$ & 2. OIE-OI \\
\hline $\mathrm{H} 2 \mathrm{O}(\mathrm{g})$ & 3. $7 F E-01$ & $1.7 \times E-01$ \\
\hline$(420) 2(g)$ & 1. $75 E-05$ & $1.95 E-05$ \\
\hline $\operatorname{co}(g)$ & $1.9 \mathrm{FE}-01$ & $1.995-01$ \\
\hline $\operatorname{LAOH}(g)$ & $9.62 E-09$ & $9.62 E-09$ \\
\hline$\left(L_{L} O H\right)_{2}(g)$ & 2. $88 E-11$ & $2.88 E-11$ \\
\hline$L 10: 120(g)$ & $5.91 E m-09$ & 5. $91 E-09$ \\
\hline$K(g)$ & 2. $36 E-09$ & $2,36 E-09$ \\
\hline $40 M(g)$ & $1.32 x-07$ & 1. $32 E-0 T$ \\
\hline (KOH)Z(g) & 1. JYE-11 & $1.37 E-11$ \\
\hline $\operatorname{Kat} 1 \mathrm{H}_{2} \mathrm{O}(\mathrm{g})$ & 4. $12 x-19$ & 4. $12 E-09$ \\
\hline$N+3(g)$ & 5. 37E-09 & 5. 37E-05 \\
\hline Seo $(g)$ & $0.00 E+\infty 0$ & $3.34 E-18$ \\
\hline $5007(g)$ & $0.00 \varepsilon+\infty 0$ & 9. 39E-24 \\
\hline H2Se (g) & $0.00 E+\infty$ & 8. $40 E-00$ \\
\hline
\end{tabular}

se - 2 se -3

6. $00 \mathrm{E}-02$

$0.00 E-02$

Se -4

$1.29 E-23 \quad 1.29 E-23$

$3.61 E-01 \quad 3.61 E-01$

$6.00 E-02$

$1.29 E-23$

7.5SE-13 13

3. $02 E-12$

3.61E-01

1. $21 E-11$

2.01E-01

2.01E-01

2.01E-01

$1.79 E-01$

1. T\%E-01

1. $7 \mathrm{mt}-01$

$1.95 E-05$ 1.95E-05

$1.95 E-05$

$1.99 E-01$

1. $99 E-01$

$1.478-0$

$9.62 E-09$

9.62E-09

2.

2. $88 E-11$

5. $715-09$

5. $91 E-09$

3. $365-09$

2. $36 E-09$

2. 36E-09

1. JZE-07

1. JZE-07

1. $32 E-07$

1.JPE-11 1. J\%E-11

1. J9E-11

4. $12 E-09$

4. $12 E-0$ ?

5. JTE-OS S. JTE-05

5. $37 E-05$

3. $34 E-17$

6. $68 E-17$

$1.6 \pi E-17$

P. JPE-23

1. $88 \mathrm{E}-22$

4. $20 E-07$

9. $40 E-07$

$1.68 E-06$

$50-5$
$6.00 E-02$
$1.29 E-23$
$3.61 E-01$
$2.72 E-11$
$2.01 E-01$
$1.79 E-01$
$1.95 E-05$
$1.99 E-01$
$9.62 E-09$
$2.87 E-11$
$5.91 E-09$
$2.36 E-09$
$1.32 E-07$
$1.39 E-11$
$4.12 E-09$
$5.37 E-05$
$1.00 E-16$
$2.82 E-22$
$2.52 E-06$

se - 6

$6.00 E-02$

$1.29 E-23$

3.61E-01

4. $33 E-11 \leftarrow$

2.01E-01

S. T9E-OI

$1.95 E-05$

$1.99 E-01$

$9.62 E-09$

$2.87 E-11$

5. $91 E-09$

2. $36 E-09$

1. $322-07$

1. उPE-11

4. $12 E-09$

5. $37 E-\infty 5$

1. 34E-16 -

$3.36 \mathrm{E}-06 \leftarrow$

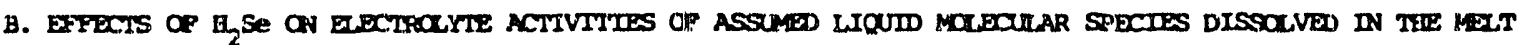

\begin{tabular}{|c|c|c|c|c|c|c|c|}
\hline $\begin{array}{l}L 12 \cos (1) \\
\text { L(10111) }\end{array}$ & $\begin{array}{l}\text { 2. उमE-01 } \\
\text { 9. } 15 E-01\end{array}$ & $\begin{array}{l}\text { 2. } 37 E-01 \\
9.15 E-03\end{array}$ & $\begin{array}{l}2 . J 7 E-01 \\
9.15 E-03\end{array}$ & $\begin{array}{l}\text { R. J7E-01 } \\
9.15 E-03\end{array}$ & $\begin{array}{l}\text { 2. JTE-01 } \\
9.15 E-03\end{array}$ & $\begin{array}{l}2.3 T E-01 \\
9.15 E-03\end{array}$ & $\begin{array}{l}2 . J 7 E-01 \\
9.15 E-03\end{array}$ \\
\hline$L(25 \theta(s)$ & $0.005=+00$ & 6. 3IE-07 & $3.15 x-06$ & W. JIE-Ob & 1. 26E -09 & $1.89 E-05$ & $2.52 E-05$ \\
\hline $\begin{array}{l}\operatorname{l} 20(1) \\
\times 2 \cos (1)\end{array}$ & $\begin{array}{l}\text { 1. } 18 E-06 \\
7.44 E-92\end{array}$ & $\begin{array}{l}1.18 E-06 \\
7.44 E-02\end{array}$ & $\begin{array}{l}1.18 E-06 \\
7.44 E-02\end{array}$ & & $\begin{array}{l}1.18 E-06 \\
7.44 E-02\end{array}$ & $\begin{array}{l}1.18 E-0.6 \\
7.44 E-0.2\end{array}$ & $\begin{array}{l}1.18 E-016 \\
7.44 E-02\end{array}$ \\
\hline $\mathrm{KOH}(1)$ & 5. 86E-04 & 3. BAE-OA & 5.86E-04 & $1.86 E-04$ & $5.868-04$ & $5.865-04$ & $5.86 E-04$ \\
\hline K2Se(s) & $0.00 E+00$ & $3.24 E-08$ & $1.62 E-07$ & $3.24 E-07$ & b. $47 \mathrm{E}=-07$ & $9.71 E-07$ & $1.295-\infty 6$ \\
\hline$\times 20(1)$ & $1.395-15$ & $1.39:-15$ & $1.39 E-15$ & 1.39E-15 & $1.39 E-15$ & $1.39 E-15$ & $1.39 E-15$ \\
\hline$N+\operatorname{Cos}(1)$ & 2. $16 E-07$ & $2.161:-09$ & 2.16E-09 & 2. $16 E-09$ & 2.16E-09 & $2.16 E-09$ & $2.16 E-\infty$ \\
\hline Ni $(O H) 2(8)$ & $3,30 E-20$ & 3. 301:- $-0 B$ & 3. 30E $-\infty \theta$ & 3. $30 E-00$ & $3,30 E-08$ & $3.30 E-08$ & $3.30 E-C \theta$ \\
\hline$N i s=(3)$ & $0.00 E+00$ & $1.981:-03$ & $9.91 E-03$ & $1.985-02$ & $3.96 E-02$ & $5.94 E-02$ & $7.928-02$ \\
\hline N1OH & 3. $18 E-05$ & 5. $18 t:-\infty$ & 3. $18 x-05$ & 5. $18 E-05$ & 5. $105-05$ & $5.18 E-03$ & $5.18 E-\infty$ \\
\hline
\end{tabular}

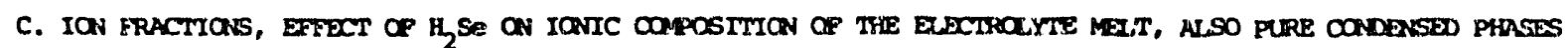

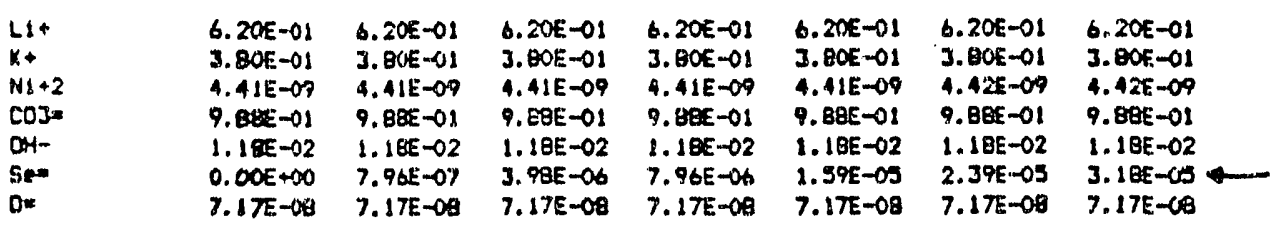

SFECIES PRESENT AS PURE COTOENSED PHASES:

Niler) yes yos yos yos yes yos 
TABLE II•4

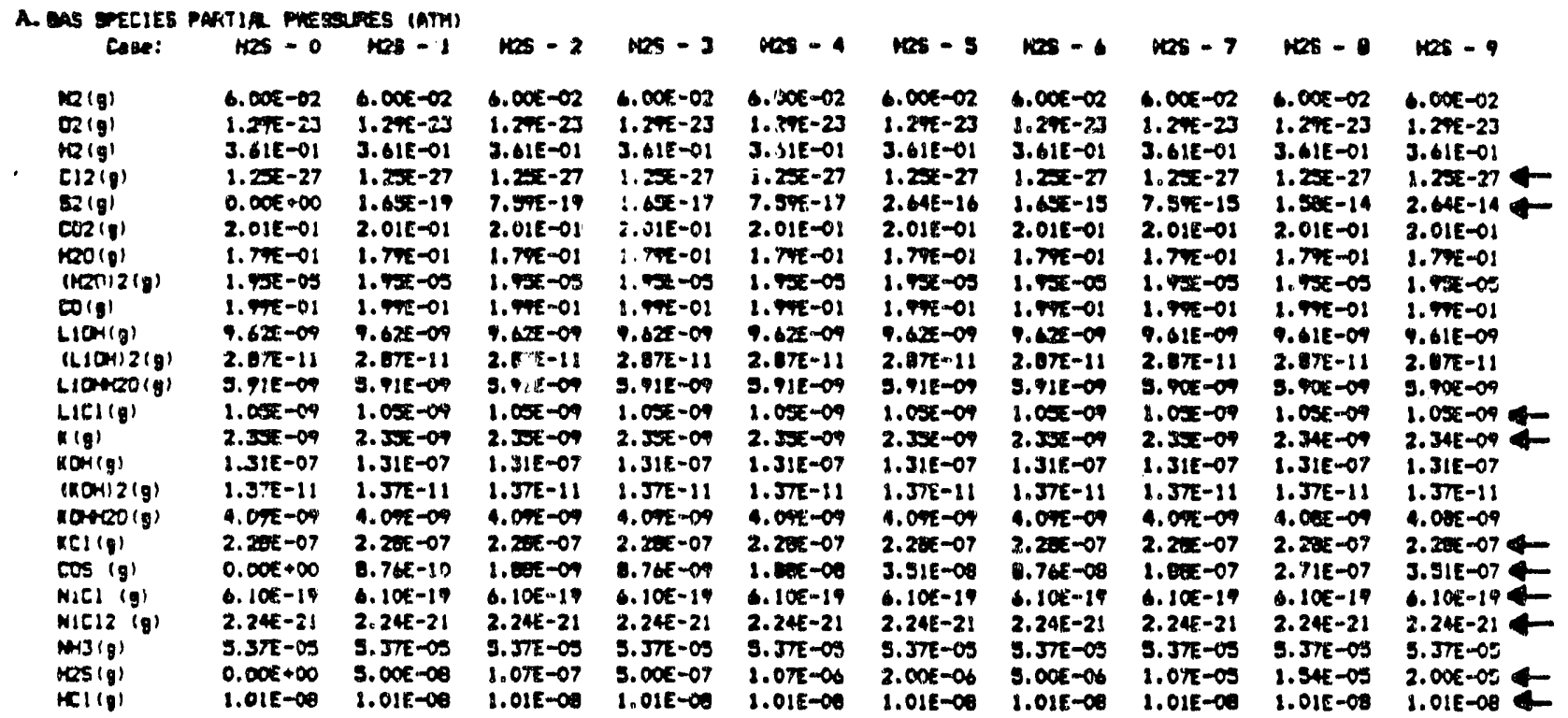

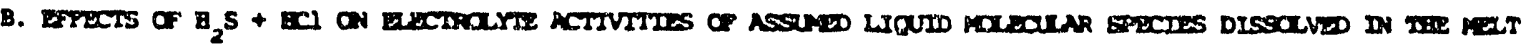

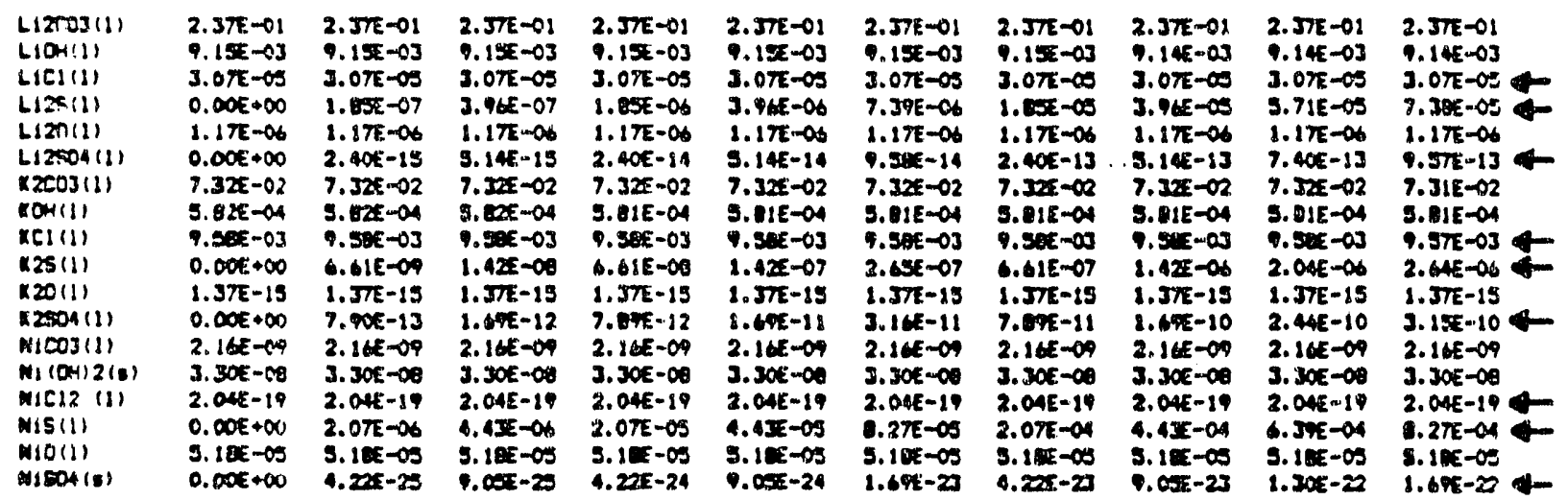

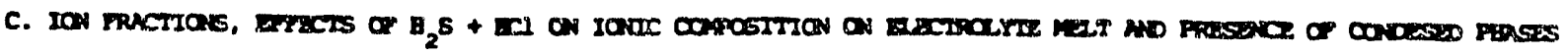

\begin{tabular}{|c|c|c|c|c|c|c|c|c|c|c|}
\hline 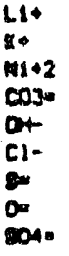 & $\begin{array}{l}\text { 1.24E }-01 \\
3.00 E-01 \\
1.47 E-\infty 9 \\
9.01 E-01 \\
1.18 E-02 \\
1.60 E-03 \\
0.00 E+\infty \\
7.18 E-\infty \\
0.01 E+\infty\end{array}$ & $\begin{array}{l}\text { 6.20E-O1 } \\
3.00 E-01 \\
4.4 \pi E-09 \\
1.00 E-01 \\
8.10 E-02 \\
1.00 E-03 \\
2.0 \pi E-07 \\
7.10 E-\infty \\
1.9 E=-13\end{array}$ & $\begin{array}{l}1.20 E-01 \\
3.60 \varepsilon-01 \\
4.47 E-01 \\
9.80 z-01 \\
1.16 E-02 \\
1.0 E-03 \\
4.44 E-07 \\
1.16 E-\infty \\
1.40 E-12\end{array}$ & $\begin{array}{l}1.20 E-01 \\
3.00 E-01 \\
4.07 L-01 \\
1.00 E-01 \\
1.16 E-02 \\
1.0 E-03 \\
2.07 E-06 \\
7.1 E E-00 \\
1.20 E-12\end{array}$ & $\begin{array}{l}\text { 1.20E-01 } \\
3.00 E-01 \\
4.17 E-01 \\
9.0 E E-01 \\
1.10 E-02 \\
1.04 E-03 \\
1.44 E-06 \\
7.11 E-\infty \\
1.40 E-11\end{array}$ & 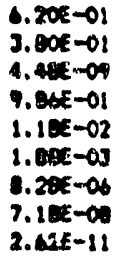 & 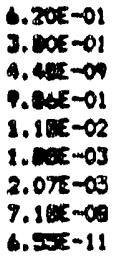 & $\begin{array}{l}1.20 E-01 \\
3.00 E-01 \\
4.45 E-09 \\
9.04 E-01 \\
1.1 E E-02 \\
1.115 E-03 \\
1.41 E-03 \\
7.18 E-08 \\
1.40 E-10\end{array}$ & 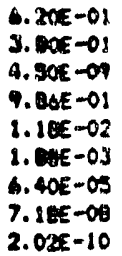 & $\begin{array}{l}\text { 6.20E-01 } \\
3.00 E-01 \\
0.31 E-09 \\
9.06 E-01 \\
8.18 E-02 \\
1.00 E-03 \\
9.20 E-05 \\
7.10 E-00 \\
2.62 E-10\end{array}$ \\
\hline
\end{tabular}

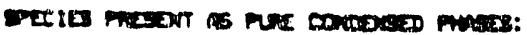

mist

Pase $m$

ros $m$ yos

+ot 
TABLE II• 5

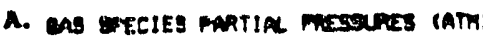

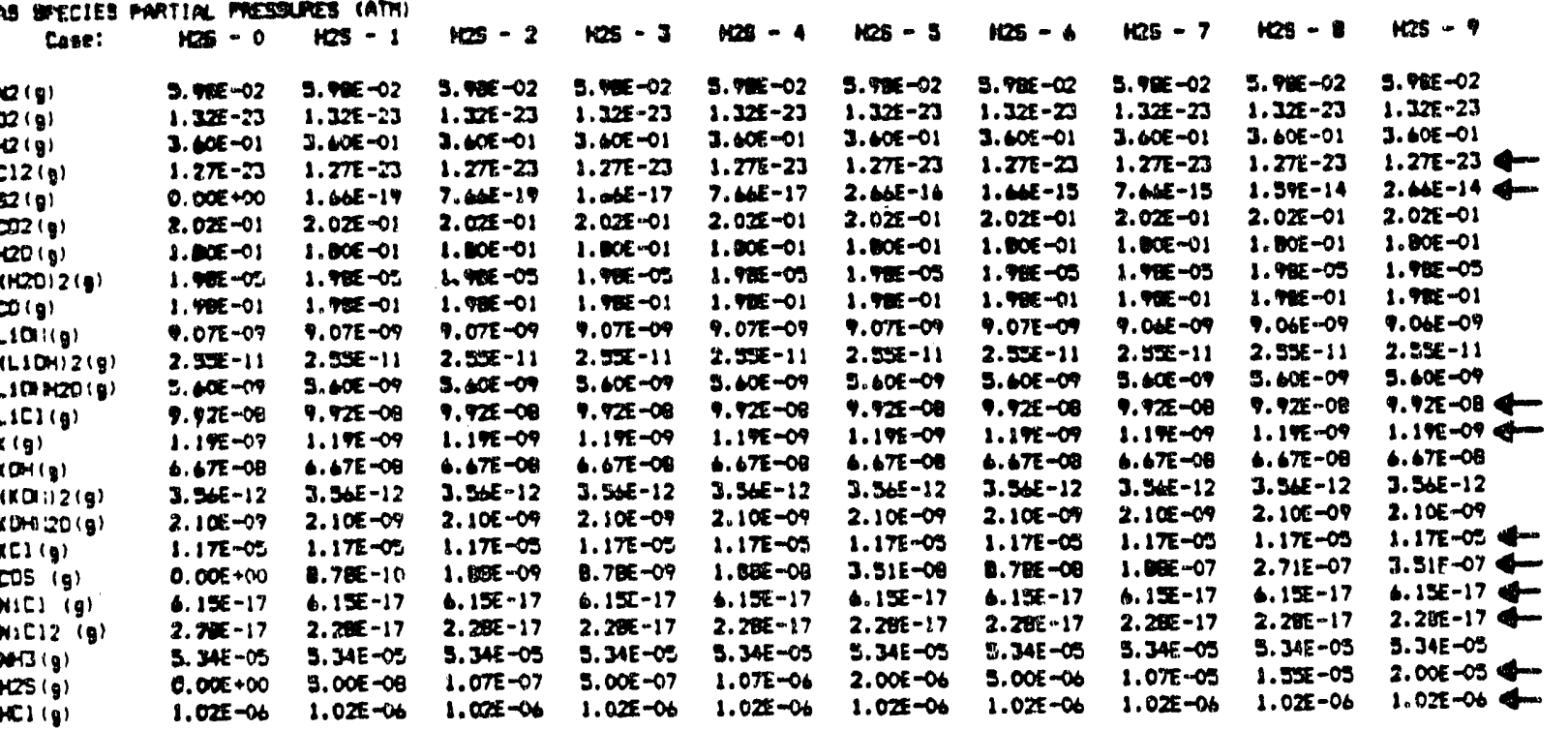

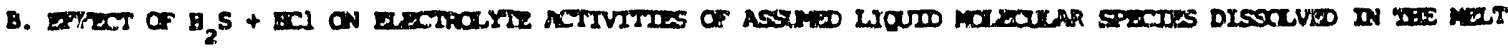

\begin{tabular}{|c|c|c|c|c|c|c|c|c|c|c|}
\hline 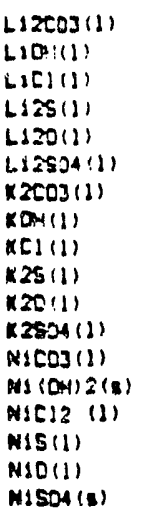 & 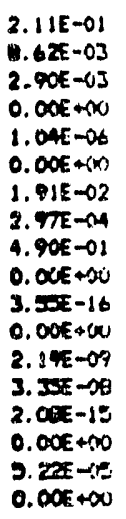 & 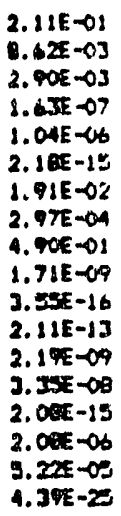 & 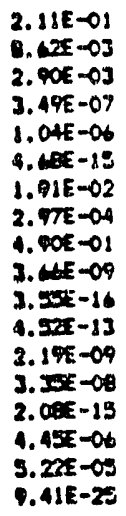 & 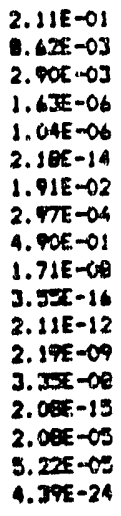 & 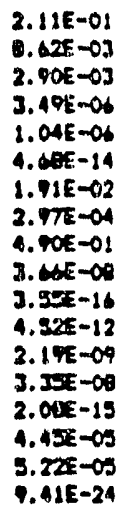 & 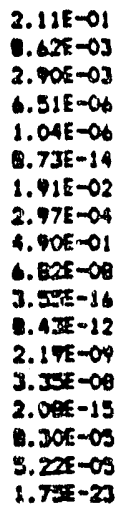 & 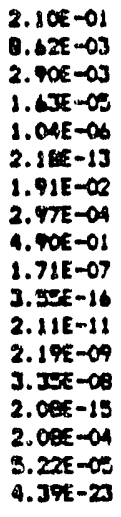 & $\begin{array}{l}2.80 E-01 \\
1.6 x E-03 \\
2.90 E-03 \\
3.49 E-65 \\
1.04 E-06 \\
4.6 E E-13 \\
1.96 E-02 \\
2.97 E-04 \\
4.90 E-01 \\
3.4 E-07 \\
3.5 E E-16 \\
4.3 x E-11 \\
2.19 E-04 \\
3.35 E-00 \\
2.08 E-15 \\
4.45 E-04 \\
3.22 E-05 \\
9.41 E-23\end{array}$ & 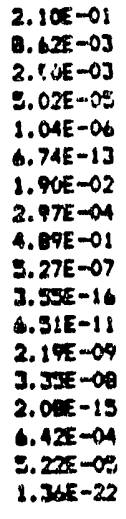 & $\begin{array}{l}2.10 E-01 \\
0.62 E-03 \\
2.90 E-03 \\
1.30 E-05 \\
1.04 E-06 \\
1.7 x E-13 \\
1.90 E-02 \\
2.97 E-04 \\
4.69 E-01 \\
6.91 E-07 \\
3.24 E-16 \\
1.42 E-11 \\
2.19 E-09 \\
3.35 E-00 \\
3.08 E-15 \\
1.30 E-04 \\
5.22 E-05 \\
1.75 E-22\end{array}$ \\
\hline
\end{tabular}

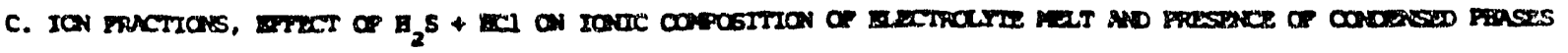

\begin{tabular}{|c|c|c|c|c|c|c|c|c|c|c|}
\hline $\begin{array}{l}61+ \\
1+ \\
W 1+2 \\
C 03= \\
01+ \\
C 1- \\
g= \\
0= \\
\infty 04=\end{array}$ & $\begin{array}{l}6.20 E-01 \\
3.00 E-01 \\
1.04 E-\infty \\
9.36 E-01 \\
1.26 E-02 \\
1.511-01 \\
0.00 E+\infty 0 \\
1.40 E-\infty 1 \\
0.00 E+\infty\end{array}$ & $\begin{array}{l}\text { 1. } 20 E-01 \\
3.00 E-01 \\
1.44 E-00 \\
1.36-01 \\
1.26-02 \\
1.51 E-01 \\
1.00 E-07 \\
1.90 E-08 \\
1.57 E-13\end{array}$ & $\begin{array}{l}\text { 1. 20E-01 } \\
3.00 E-01 \\
1.64 E-\infty \\
1.34 E-01 \\
1.2 \omega E-02 \\
1.31 E-01 \\
3.07 E-07 \\
1.70 E-00 \\
9.01 E-13\end{array}$ & $\begin{array}{l}1.201 .01 \\
3.00 E-01 \\
1.44 E-08 \\
0.36 E-01 \\
1.26 E-02 \\
1.51 E-01 \\
1.00 E-06 \\
1.00 t-08 \\
4.57 t-12\end{array}$ & $\begin{array}{l}\text { 6. } 20 E-01 \\
\text { 3. } 00 E-01 \\
\text { 1. } 14 E-00 \\
\text { 8. } 34 E-01 \\
1.24 E-02 \\
1.31 E-01 \\
3.07 E-06 \\
\text { 1. } 90 E-00 \\
\text { 9.01E-12 }\end{array}$ & $\begin{array}{l}6.20 E-01 \\
3.00 E-01 \\
1.45 E-00 \\
1.36 E-01 \\
1.26 E-02 \\
1.51 E-01 \\
7.21 E-06 \\
0.90 E-00 \\
1.01 E-11\end{array}$ & 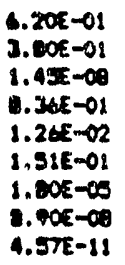 & 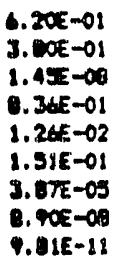 & $\begin{array}{l}1.20 E-01 \\
3.00 E-01 \\
1.45 E-\infty \\
9.34 E-01 \\
1.26 E-02 \\
1.51 E-01 \\
3.5 T E-03 \\
0.90 E-00 \\
1.41 E-10\end{array}$ & $\begin{array}{l}1.20 E-01 \\
3.60 E-01 \\
1.45 E-00 \\
8.36 E-01 \\
1.26 E-02 \\
1.51 E-01 \\
7.21 E-09 \\
0.40 E-00 \\
1.0 T E-10\end{array}$ \\
\hline
\end{tabular}

merites mesort as rure conwersed mases:

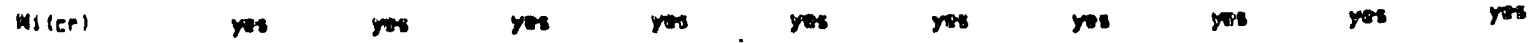




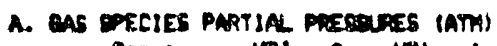

\begin{tabular}{|c|c|c|c|c|c|c|c|c|c|c|}
\hline Cane: & $|n|-0$ & $\mathrm{MEl}-1$ & $1=1-2$ & $\mathrm{NCl}-3$ & KCl - 4 & $|c|-5$ & ACs -6 & Mel-7 & $|x|-B$ & $\operatorname{MEl}=9$ \\
\hline 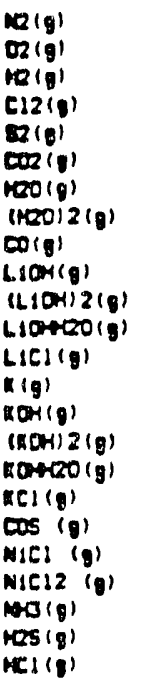 & 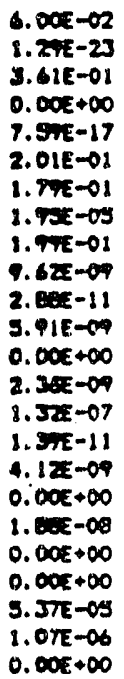 & 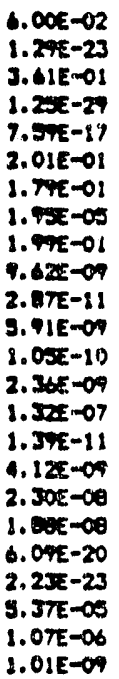 & 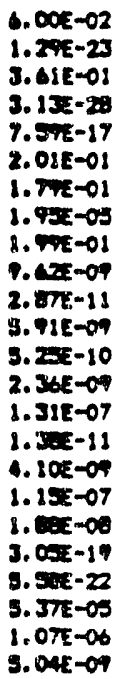 & 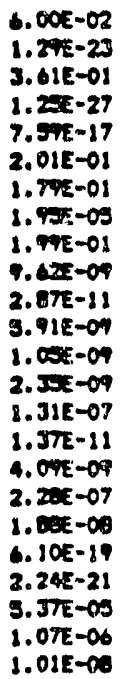 & 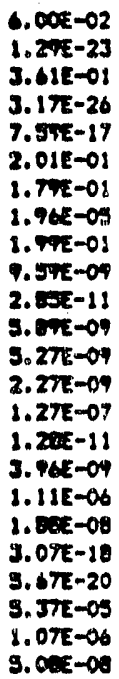 & 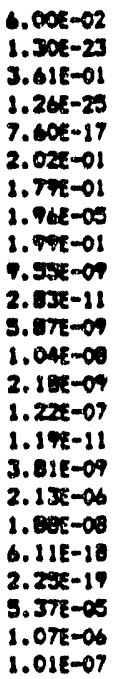 & 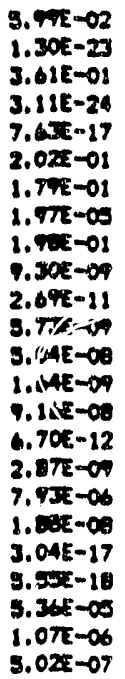 & 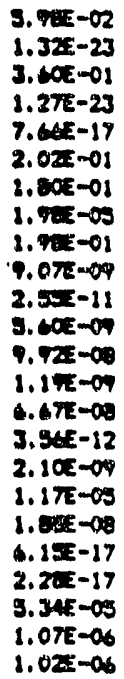 & 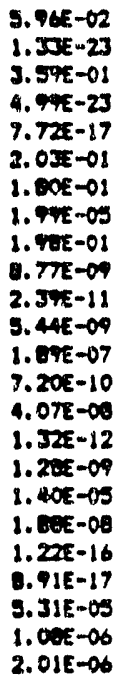 & 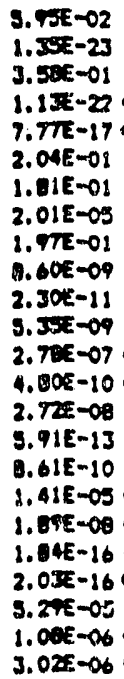 \\
\hline
\end{tabular}

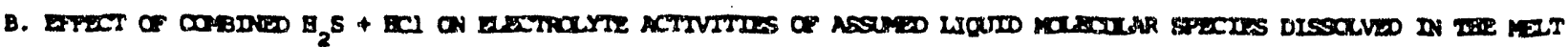

\begin{tabular}{|c|c|c|c|c|c|c|c|c|c|c|}
\hline 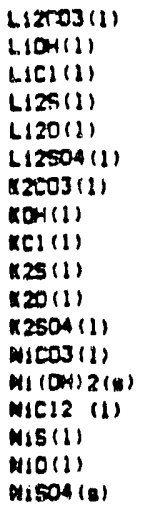 & $\begin{array}{l}2.37 E-01 \\
1.15 E-03 \\
0.00 E-00 \\
3.97 E-06 \\
1.18 E-06 \\
5.15 E-14 \\
7.44 E-02 \\
5.36 E-0.4 \\
0.00 E+\infty 0 \\
1.44 E-07 \\
1.37 E-15 \\
1.72 E-11 \\
2.14 E-09 \\
3.30 E-00 \\
0.00 E+\infty 0 \\
4.45 E-05 \\
5.18 E-05 \\
9.04 E-24\end{array}$ & 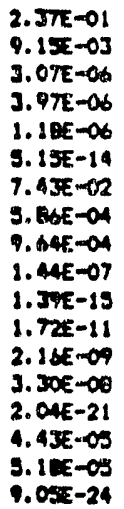 & 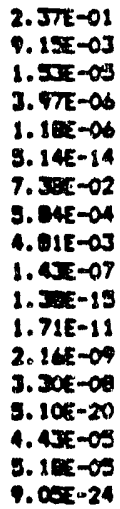 & 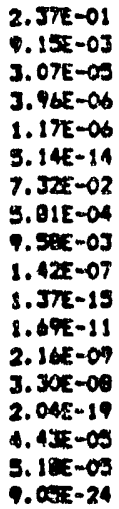 & 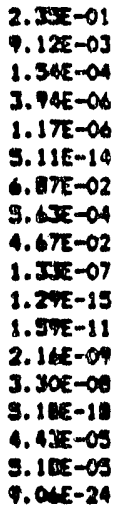 & 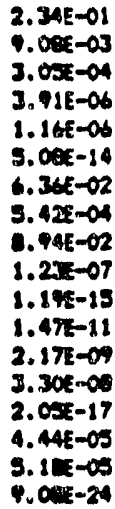 & 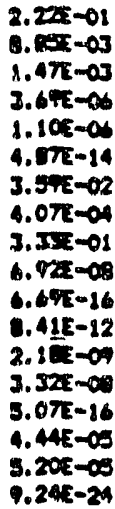 & 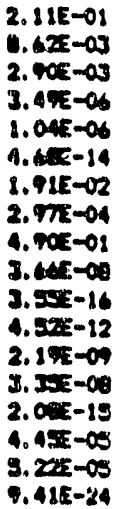 & 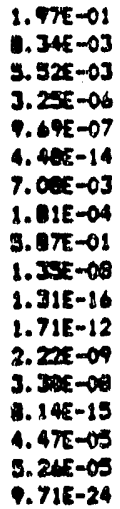 & 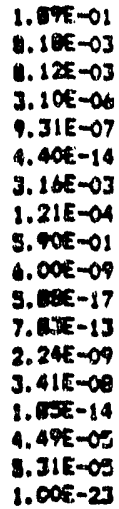 \\
\hline
\end{tabular}

1

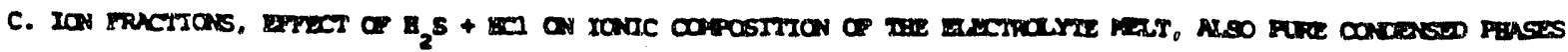

\begin{tabular}{|c|c|c|c|c|c|c|c|c|c|c|}
\hline 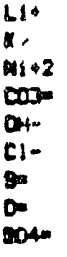 & $\begin{array}{l}\text { 1. } 20 E-01 \\
3.00 E-01 \\
4.41 E-09 \\
9.00 E-01 \\
1.10 E-02 \\
0.005-00 \\
4.450-06 \\
7.172-00 \\
1.41 E-11\end{array}$ & $\begin{array}{l}1.20 E-01 \\
3.80 k-01 \\
4.41 E-09 \\
9.006-01 \\
1.1 E=-02 \\
1.01 E=04 \\
4.45 E-06 \\
7.17 E-00 \\
1.41 E-11\end{array}$ & $\begin{array}{l}6.20 E-01 \\
2.50 E-01 \\
4.44 E-09 \\
9.87 E-01 \\
1.10 E-02 \\
9.20 E-04 \\
4.45 E-\infty \\
7.8 E-\infty \\
1.41 E-11\end{array}$ & 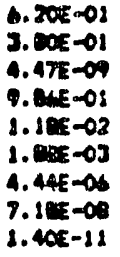 & $\begin{array}{l}8.205-01 \\
3.00-01 \\
4.75-01 \\
9.79 k-01 \\
8.145-02 \\
9.345-03 \\
4.415-01 \\
7.205-02 \\
8 . x 05-11\end{array}$ & 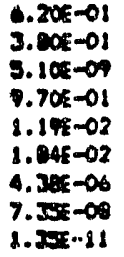 & 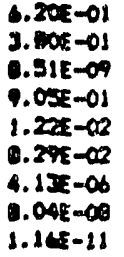 & 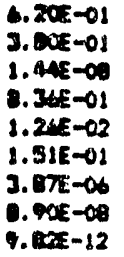 & $\begin{array}{l}1.20 E-01 \\
3.00 E-01 \\
3.00 E-00 \\
7.345-01 \\
1.325-02 \\
2.51 E-01 \\
3.47 E-08 \\
1.05 E-07 \\
7.465-12\end{array}$ & 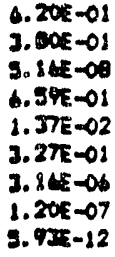 \\
\hline
\end{tabular}

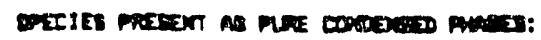

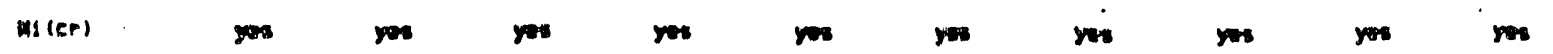


TABLE II 7

A. GAS SPECIES PARTIAL PKESSURES (ATM)

\begin{tabular}{|c|c|c|c|c|c|c|c|c|}
\hline Case: & $\mathrm{Ftz} /$ Sen & $\mathrm{Fb} / \mathrm{SE}-1$ & $P b / 5 p-2$ & $\mathrm{~Pb} / \mathrm{Se}-3$ & $\mathrm{Fo} / \mathrm{Se}-4$ & $\mathrm{Ft} / \mathrm{s}=-5$ & $\mathrm{~Pb} / \mathrm{Se}-6$ & $\mathrm{~Pb} / \mathrm{Se}-7$ \\
\hline$N_{2}(g)$ & 6. D.P.E-02 & $6.0 D E-02$ & 6. ODE-02 & $6.00 E-02$ & $6.00 E-02$ & $6.00 E-02$ & $6.00 E-02$ & $6.00 E-02$ \\
\hline $02(g)$ & $1.29 E-2 J$ & $1.29 E-23$ & $1.29 E-23$ & $1.29 E-23$ & $1.29 E-23$ & $1.29 E-23$ & $8.29 E-23$ & $1.29 E-23$ \\
\hline$H_{2}(g)$ & $3.61 \mathrm{E}-01$ & $3.61 E-01$ & ت $61 E-01$ & $3.61 \mathrm{E}-01$ & $3.61 E-01$ & $3.61 E=01$ & $3.61 E-01$ & $3.61 \mathrm{E}-01$ \\
\hline $\operatorname{Se} 2(g)$ & $0.0 N E+\infty$ & $1.98 E-15$ & 4. $77 E-14$ & 4. $39 E-13$ & $1.75 E-12$ & $7,02 E-12$ & $1.95 E-11$ & $9.54 E-11$ \\
\hline $\cos (g)$ & 2. DIE-01 & $2.01 E-01$ & 2.01E-01 & 2. OLE-OI & $2.01 E-01$ & $2.01 E-01$ & 2.01E-01 & $2.01 E-01$ \\
\hline $\mathrm{H} 2 \mathrm{O}(\mathrm{g})$ & $1.79 E-01$ & $1.79 E-01$ & $1.79 E-01$ & $1.79 E-01$ & $1.79 E-01$ & $1.79 E-01$ & $1.79 E-01$ & $1.79 E-01$ \\
\hline$(\mathrm{H} 2012(\mathrm{~g})$ & $1.95 E-05$ & $1.95 E-05$ & $1.95 \mathrm{E}-0 \mathrm{~S}$ & 1. $955=05$ & $1.95 E-05$ & $1.95 E-05$ & $1.95 \mathrm{E}-05$ & $1.95 E-05$ \\
\hline$C D(g)$ & $1.99 E-01$ & $1.99 E-01$ & $1.99 E-01$ & $1.99 E-01$ & $1.99 E-01$ & $1.99 E-01$ & $1.99 E-01$ & $1.99 E-01$ \\
\hline L.1OH (g) & 9. $62 E-09$ & $9.62 E-09$ & $9.62 E-09$ & $9.62 \mathrm{E}-09$ & $9.62 E-09$ & $9.62 E-09$ & $9.62 E-09$ & $9.62 E-09$ \\
\hline$(L L O M) 2(g)$ & 2. BBE-11 & 2. $B E E-11$ & 2. $88 E-11$ & $2.88 E-11$ & 2.8BE-11 & 2. B8E-11 & $2.87 E-11$ & $2.87 E-11$ \\
\hline L101nt20(g) & $5.91 E-09$ & $5.91 E-09$ & $5.91 E-09$ & $5.91 E-09$ & $5.91 E-09$ & $5.91 E-09$ & $3.91 E-09$ & $5.91 E-09$ \\
\hline$K(g)$ & 2. 3SE-CO & $2.36 E-09$ & $2.36 E-09$ & $2.36 E-09$ & $2.36 E-09$ & $2.36 E-09$ & $2.36 E-09$ & 2. $36 E-09$ \\
\hline$K O H(g)$ & 1. $32 E-07$ & $1.32 E-07$ & $1.32 E-07$ & $1.32 E-07$ & $1.32 E-07$ & $1.32 E-07$ & $1.32 E-07$ & $1.32 E-07$ \\
\hline$(K O H) 2(g)$ & 1. J9E-11 & 1. $39 E-11$ & 1. $39 E-11$ & $1.39 E-11$ & $1.39 E-11$ & 1. $39 E-11$ & $1,39 E-11$ & $1.39 E-11$ \\
\hline KOHHIZ (g) & 4.12E-09 & $4.12 E-09$ & $4.12 E-09$ & $4.12 E-09$ & $4.12 E-09$ & 4. $12 E=09$ & $4.12 E-09$ & 4. $12 E-09$ \\
\hline $\operatorname{POH}(g)$ & $5.26 E-10$ & $\$ .20 E-10$ & $5.26 E-10$ & $5.26 E-10$ & $5.26 E-10$ & $5.26 E-10$ & $5.26 E-10$ & $5.26 E-10$ \\
\hline $\mathrm{Pb}(g)$ & $2.35 E-06$ & $2.53 E-06$ & 2. 5SE-06 & $2.55 E-06$ & $2.55 E-06$ & $2.55 E-06$ & $2.55 E-06$ & $2.55 E-06$ \\
\hline$P b 2(g)$ & 2. J2E-12 & $2.27 E-12$ & 2. $32 \mathrm{E}-12$ & 2. $32 \mathrm{E}-12$ & 2. $32 E-12$ & $2.32 E-12$ & $2.32 E-12$ & $2.3 x-12$ \\
\hline$P b D(g)$ & 1. 1.JE-12 & $1.02 E-12$ & 1. त3E- 12 & $1.03 E-12$ & $1.03 E-12$ & $1.03 E-12$ & $1.03 E-12$ & $1.03 E-12$ \\
\hline Pose (g) & $0.1)$ DE+DOD & $\% .44 E-08$ & $3.7 \mathrm{SE}-07$ & $1.12 \mathrm{E}-06$ & $2.24 E-O B$ & $4.48 E-06$ & $7.46 E-06$ & $1.65 E-05$ \\
\hline $\mathrm{NH} 3(\mathrm{~g})$ & $5.37 E-05$ & $3.37 E-05$ & $5.37 E-05$ & 5. J7E-OS & $5.37 E-05$ & $5.37 E-05$ & $5.37 E-05$ & 5. $37 E-0.5$ \\
\hline $\mathrm{SeO}(\mathrm{g})$ & $0.1 \mathrm{k}) E+00$ & $8.56 E-19$ & $4.24 E-18$ & $1.27 E-17$ & $2.55 E-17$ & $5.09 E-17$ & 8.49E-17 & $1.88 E-16$ \\
\hline setr. $(g)$ & $0.1 N E+\infty$ & $2.40 E-24$ & $1.19 E-23$ & 3. $58 E-23$ & $7.16 \mathrm{E}-23$ & $1.43 E-22$ & $2.39 E-22$ & 5. $2 B E-22$ \\
\hline HzSe (g) & $0.0 O E+D O$ & $2.15 E-08$ & $1.07 E-07$ & $3.20 E-07$ & $6.40 E-07$ & $1.28 E-06$ & $2.13 E-06$ & $4.772-06$ \\
\hline
\end{tabular}

B. EFFECT OF COMBINED (PD) + Se ON EIECTROLYTE ACTIVITIES OF LIOUID MOLECUIAR SPECIES IN THE MELT

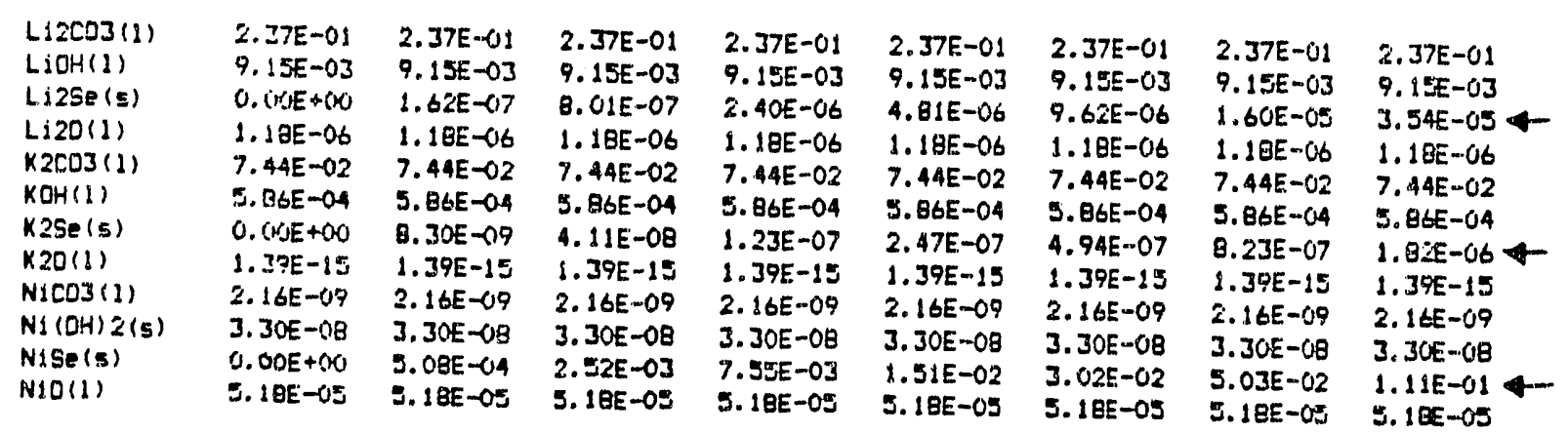

C. ION FRACTIONS, EFFECT OF (PD) + Se ON IONIC DOMPOSITION OF THE MELT, AND AISO

\begin{tabular}{|c|c|c|c|c|c|c|c|c|}
\hline $\begin{array}{l}\text { Lit } \\
K+ \\
N i+2 \\
\text { CO3= } \\
\text { Oit } \\
\text { Sex } \\
D=\end{array}$ & $\begin{array}{l}6.20 E-01 \\
3.81) E-01 \\
4.41 E-09 \\
9.9 B E-01 \\
1.18 E-02 \\
0.00 E+00 \\
7.17 E-08\end{array}$ & $\begin{array}{l}\text { 6. } 20 E-01 \\
3.80 E-01 \\
4.11 E-19 \\
9.8 E E-01 \\
1.18 E-02 \\
2.04 E-07 \\
7.17 E-0.9\end{array}$ & $\begin{array}{l}6.20 E-01 \\
3.80 E-01 \\
4.41 E-09 \\
9.88 E-01 \\
1.18 E-02 \\
1.01 E-06 \\
7.17 E-08\end{array}$ & $\begin{array}{l}6.20 E-01 \\
3.80 E-01 \\
4.41 E-09 \\
9.8 B E-01 \\
1.18 E-02 \\
3.03 E-06 \\
7.17 E-08\end{array}$ & $\begin{array}{l}6.20 E-01 \\
3.80 E-01 \\
4.41 E-09 \\
9.88 E-01 \\
1.18 E-02 \\
6.06 E-06 \\
7.17 E-08\end{array}$ & $\begin{array}{l}6.20 E-01 \\
3.80 E-01 \\
4.41 E-09 \\
9.88 E-01 \\
1.18 E-02 \\
1.21 E-05 \\
7.17 E-08\end{array}$ & $\begin{array}{l}6.20 E-01 \\
3.00 E-01 \\
4.42 E-09 \\
9.88 E-01 \\
1.1 B E-02 \\
2.02 E-05 \\
7.17 E-08\end{array}$ & $\begin{array}{l}\text { 6. 20E-01 } \\
3.80 E-01 \\
4.43 E-09 \\
9.88 E-01 \\
1.10 E-02 \\
4.47 E-05 \\
7.17 E-08\end{array}$ \\
\hline
\end{tabular}

SFECIES FRESENT AS FLNE CONDENSED PHASES:

\begin{tabular}{|c|c|c|c|c|c|c|c|c|}
\hline $\begin{array}{l}\text { PDSE (s) } \\
\text { PD(1) } \\
\text { NS(er) }\end{array}$ & $\begin{array}{l}\text { no } \\
\text { yes } \\
\text { yes }\end{array}$ & $\begin{array}{l}\text { no } \\
\text { no } \\
\text { yes }\end{array}$ & $\begin{array}{l}\text { no } \\
\text { yes } \\
\text { yes }\end{array}$ & $\begin{array}{l}\text { no } \\
\text { yes } \\
\text { yes }\end{array}$ & $\begin{array}{l}\text { no } \\
\text { yes } \\
\text { yes }\end{array}$ & $\begin{array}{l}\text { no } \\
\text { yes } \\
\text { yes }\end{array}$ & $\begin{array}{l}\text { no } \\
\text { yes } \\
\text { yes }\end{array}$ & $\begin{array}{l}\text { yes } \\
\text { yes } \\
\text { yes }\end{array}$ \\
\hline
\end{tabular}


TABLE II•8

A. GAS SPECIES PARTIAL PKESSURES (ATM)

\begin{tabular}{|c|c|c|c|c|c|c|c|c|}
\hline Case: & In/Se- & $2 n / 5 e-1$ & $2 n / 5=-2$ & $2 n / S e-3$ & $2 n / 5 e-4$ & $2 n / 5 e-5$ & $2 n / 5 w-6$ & $2 n / 5 e-7$ \\
\hline$N 2(g)$ & $6.00 E-02$ & $6.00 E-02$ & $6.00 E-02$ & 6. DOE-O2 & $6.00 E-02$ & $6.00 E-02$ & $0.00 E-02$ & $6.00 E-02$ \\
\hline $02(g)$ & $1.29 E-23$ & $1.29 E-23$ & $1.29 E-23$ & 1.29E-23 & $1.29 E-23$ & $1.29 E-23$ & $1.29 E-23$ & $1.29 E-23$ \\
\hline$H_{2}(g)$ & 3.61E-01 & $3.61 E-01$ & $3.61 E-01$ & $3.61 E-01$ & 3. $61 E-01$ & $3.61 E-01$ & $3.61 E-01$ & $3.61 E-01$ \\
\hline Sez $2(g)$ & $0.1 D E+D O$ & $3.02 E-14$ & $7.55 E-13$ & $6.79 E-12$ & $2.72 E-11$ & $1.09 E-10$ & $3.02 E-10$ & $7.445-10$ \\
\hline $\cos (g)$ & 2.DLE-O1 & $2.01 E-01$ & $2.01 E-01$ & $2.01 E-01$ & $2.01 E-01$ & $2.01 E-01$ & $2.01 E-01$ & 2.01E-01 \\
\hline$H 2 O(g)$ & $1.79 E-01$ & $1.79 E-01$ & $1.79 E-01$ & $1.79 E-01$ & $1.79 E-01$ & $1.79 E-01$ & $1.79 E-01$ & $1.79 E-01$ \\
\hline (H2O) 2 (g) & $1.95 E-0.5$ & $1.95 E-05$ & $1.75 E-05$ & $1.95 E-05$ & $1.95 E-05$ & $1.95 \mathrm{SE}-0 \mathrm{~S}$ & $1.95 E-05$ & $1.95 E-05$ \\
\hline $\operatorname{Co}(g)$ & $1.99 E-01$ & $1.99 E-01$ & $1.99 E-01$ & $1.99 E-01$ & $1.99 E-01$ & $1.99 E-01$ & $1.99 E-01$ & $1.99 E-01$ \\
\hline$L 1 O H(g)$ & 9.6.2E-09 & $9.62 E-09$ & $9.62 E-09$ & $9.62 E-09$ & $9.62 E-09$ & $9.62 E-09$ & $9.62 E-09$ & $9.62 E-09$ \\
\hline$(L I \cap H) Z(g)$ & 2. $8 B E-11$ & 2. $88 E-11$ & 2. $88 E-11$ & 2. $88 E-11$ & $2.87 E-11$ & $2.87 E-11$ & $2.87 E-11$ & 2.8TE-11 \\
\hline $\operatorname{LIOLH} 20(g)$ & $5.91 E-09$ & $3.91 E-09$ & 5.91E-09 & $5.91 E-09$ & $5.91 E-09$ & $5.91 E-09$ & $3.91 E-09$ & $5.91 E-09$ \\
\hline$K(g)$ & $2.37 E-09$ & $2.36 E-09$ & 2.36E-09 & $2.36 E-09$ & $2.36 E-09$ & $2.36 E-09$ & $2.36 E-09$ & $2.36 E-09$ \\
\hline $\operatorname{KOH}(g)$ & 1. $32 E-07$ & $1.32 E-07$ & 1. 32E-07 & 1. $32 E-07$ & $1.32 \mathrm{E}-07$ & 1. 32E-07 & $1.32 E-07$ & $1.3 z E-07$ \\
\hline (KOHI) $2(\mathrm{~g})$ & 1. 39E-11 & $1.39 E-11$ & $1.39 E-11$ & 1. 3gE-11 & $1.39 E-11$ & $1.39 E-11$ & $1,39 E-11$ & $1.3 q E-11$ \\
\hline $\mathrm{KOHH} 2 \mathrm{O}(\mathrm{g})$ & 4. $12 E-09$ & $4.12 E-09$ & $4.12 E-09$ & $4.12 E-09$ & 4.12E-09 & $4.12 E-09$ & $4,12 E-09$ & 4. $12 E-09$ \\
\hline $2 n(g)$ & $1.50 E-05$ & 1.50E-05 & 1.50E=05 & 1. SOE-05 & 1.50E-05 & $1.50 \mathrm{E}-05$ & $1.50 E-05$ & $1.55 E-05$ \\
\hline $\mathrm{NH3}(g)$ & 5. 37E- 05 & $5.37 E-05$ & $5.37 E-05$ & $5.37 E-05$ & 5. 37E-05 & 5.37E-05 & $5.37 E-05$ & 9. 37E-05 \\
\hline $\ln 5 e(g)$ & $0.0 n E+\infty D$ & $2.31 E-16$ & $1.15 E-15$ & $3.46 E-15$ & $6.92 E-15$ & $1.38 E-14$ & $2.31 E-14$ & $3.74 E-14$ \\
\hline $\operatorname{sed}(g)$ & $0.1 D E E+100$ & $3.34 E-18$ & $1.67 E-17$ & $5.01 E-17$ & $1.00 E-16$ & $2.00 E-16$ & $3.34 E-16$ & $5.24 E-16$ \\
\hline Se0\% (g) & $0.00 E+00$ & $9.39 E-24$ & $4.69 E-23$ & 1. $41 E-22$ & 2. $82 E-22$ & $5.63 E-22$ & $9.39 E-22$ & 1. $4 \pi E-21$ \\
\hline H2Se $(g)$ & $0.00 E+D 0$ & $8.40 E-08$ & 4. $20 E-07$ & $1.26 E-06$ & $2.52 E-06$ & $5.04 E-06$ & $8.40 E-06$ & $1.3 x=-05$ \\
\hline
\end{tabular}

B. EFFECT OF COMBINED $(\mathrm{zn})+$ Se ON EJECTROLYTE ACTIVITTIRS OF LIQUTD MOLDCULAR SPECIES IN THE METT

\begin{tabular}{|c|c|c|c|c|c|c|c|c|}
\hline Li2CO3(1) & $2.37 E-011$ & $2.37 E-01$ & $2.37 E-01$ & 2. 37E-01 & $2.37 E-01$ & $2.37 E-01$ & $2.37 E-01$ & 2. 37E-01 \\
\hline LiOH(1) & $9.15 E-03$ & $9.15 E-03$ & $9.15 E-03$ & 9. 1EE-03 & $9.15 E-03$ & $9.15 E-03$ & $9.15 E-03$ & $9.15 E-03$ \\
\hline L12Se (E) & $0.00 E+00$ & $6.31 E-07$ & 3. 15E-06 & $9.46 E-06$ & $1.89 E-05$ & $3.785-05$ & $6.30 E-05$ & $9.89 E-05$ \\
\hline $\operatorname{Li20}(1)$ & 1.1 $3 E-156$ & $1.18 E-0 S$ & $1.18 E-06$ & 1. $1 B E-06$ & 1. $19 E-06$ & 1.18E-06 & 1. $18 E-06$ & $1.17 E-06$ \\
\hline$k 2 \cos (1)$ & $7.44 E-0 \%$ & $7.44 E-02$ & $7.44 E-02$ & $7.44 E-02$ & $7.44 E-02$ & $7.44 E-02$ & $7.43 E-02$ & $7.43 E-02$ \\
\hline $\mathrm{KOH}(8)$ & J. B6E-(14 & 5. BGE-OA & $5.86 E-04$ & 5. $86 E-04$ & 5.86E-04 & $5.86 E-04$ & 5. BGE-OA & $5.86 E-04$ \\
\hline$K 25 e(5)$ & $0.00 E+10$ & $3.24 E-0 B$ & 1. $62 E-07$ & $4.86 E-07$ & $9.71 E-07$ & $1.94 E-06$ & $3.23 E-06$ & $5.07 E-06$ \\
\hline$K 20(1)$ & $1.39 E-15$ & $1.39 E-15$ & 1. 39E-15 & 1.39E-15 & $1.39 E-15$ & $1.39 E-15$ & $1.39 E-15$ & $1.39 E-15$ \\
\hline $\operatorname{NiCO3}(1)$ & 2.16E- & $2.16 E-09$ & $2.16 E-09$ & $2.16 E-09$ & $2.16 E-09$ & $2.165-09$ & $2.16 E-09$ & $2.16 E-09$ \\
\hline $\mathrm{Ni}(\mathrm{OH}) 2(\mathrm{~s})$ & $3.30 E-D B$ & $3.30 E-018$ & $3.30 E-08$ & 3. $30 E-0 E$ & 3. $30 E-08$ & $3.30 E-O B$ & $3.30 E-08$ & 3. 3CE-CB \\
\hline NiSe (s) & $0.000+000$ & $1.98 E-03$ & $9.91 E-03$ & $2.97 E-02$ & $5.94 E-02$ & 1.19E-O1 & $1.98 E-01$ & 3. $11 E-01$ \\
\hline$N ! O(1)$ & 5.19E-05 & Y. $1 \theta E-05$ & $5.18 E-05$ & 5. $1 B E-0 \mathrm{E}$ & $5.18 E-05$ & $5.18 E-05$ & $5.18 E-05$ & $5.18 E-05$ \\
\hline
\end{tabular}

c. ION FRACTIONS, EFFECT OF $(\mathrm{z} n)+$ Se ON IONIC CONPOSIITON OF THE MELT, AND ALSO

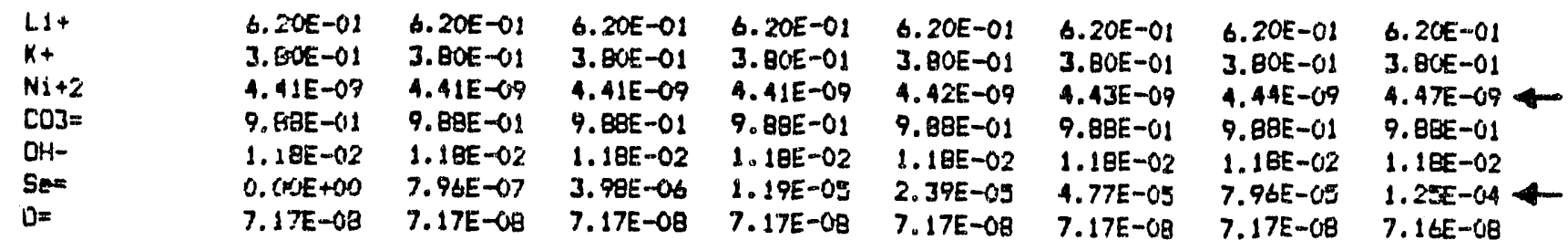

SFULIES FFESENT AS PURE COHDENSTI PHASES:

$\begin{array}{lllllllll}\text { InSo(s) } & \text { no } & \text { no } & \text { no } & \text { no } & \text { no } & \text { no } & \text { no } & \text { yes } 4- \\ \text { NI }(e .-) & \text { yes } & \text { yes } & \text { yes } & \text { yes } & \text { yes } & \text { yes } & \text { yes } & \text { yes }\end{array}$


TABLE II・9

A. BAS SPECIEg PARTIAL PRESSLRES (ATM)

\begin{tabular}{|c|c|c|c|c|c|c|c|c|c|}
\hline Case: & Sn: $19-0$ & $\mathrm{Sn} / \mathrm{Se}-1$ & $\mathrm{Sn} / \mathrm{Se}-2$ & $\mathrm{Sn} / \mathrm{Se}-3$ & $\mathrm{Sn} / \mathrm{Se}^{-4}$ & $\mathrm{Sn} / \mathrm{Se}-5$ & $\mathrm{Sn} / \mathrm{Se}-6$ & $\mathrm{Sn} / \mathrm{Se}-7$ & $\mathrm{sn} / 9 \mathrm{e}-\mathrm{B}$ \\
\hline$\left(g^{\prime}\right)$ & 6. ONE-OZ & $6.00 E-02$ & $6.00 E-02$ & $6.00 E-02$ & $6.00 E-02$ & $6.00 E-02$ & $6.00 f-02$ & 6.00E-02 & $6.00 E-02$ \\
\hline$(g)$ & $1.29 \mathrm{E}-23$ & $1.29 E-23$ & $1.29 E-23$ & $1.29 E-23$ & $1.29 E-23$ & $1.29 E-23$ & $1.29 E-23$ & $1.29 E-23$ & $1.29 E-23$ \\
\hline (g) & 3. E1E-01 & $3.61 E-01$ & $3.61 E-01$ & $3.61 E-01$ & $3.61 E-01$ & $3.61 \mathrm{E}-01$ & $3.61 E-01$ & $3.61 E-01$ & $3.61 E-01$ \\
\hline $2(9)$ & $0.00 E+\infty 0$ & $7.38 E-17$ & 1. $8 E E-15$ & $1.66 \mathrm{E}-14$ & $6.64 E-14$ & $2.665-13$ & $7.38 E-13$ & $1.94 E-12$ & $6.72 E-11$ \\
\hline $2(g)$ & $2.01 E-01$ & $2.01 E-01$ & $2.01 E-01$ & $2.02 E-01$ & $2.01 E-01$ & $2.01 E-01$ & $2.01 E-01$ & $2.01 E-01$ & $2.01 E-01$ \\
\hline $0(g)$ & 1.79E-01 & $1.79 E-01$ & $1.79 E-01$ & $1.79 E-01$ & $1.79 E-01$ & $1.79 E-01$ & $1.79 E-01$ & $1.79 E-01$ & $1.79 E-01$ \\
\hline $2(2012(g)$ & $1.95 E-05$ & $1.955-05$ & $1.95 E-0=$ & 1. $95 E-05$ & 1. $95 \mathrm{E}-05$ & $1.95 E-05$ & $1.95 E-05$ & 1.9EE-0s & $1.95 E-05$ \\
\hline$g(g)$ & 1.97E-01 & $1.99 E-01$ & $1.49 E-01$ & $1.99 E-01$ & $1.99 E-01$ & $1.99 E-01$ & $1.99 E-01$ & $1.99 E-01$ & $1.99 E-01$ \\
\hline OH $(g)$ & $9.62 E-09$ & $9.62 E-09$ & $9.62 E-09$ & $9.62 E-09$ & $9.62 E-09$ & $9.62 E-09$ & $9.62 E-\infty 9$ & $9.625-09$ & $9.62 E-09$ \\
\hline$(\mathrm{OHH}) 2(\mathrm{~g})$ & 2. Q日E-11 & $2.88 E-11$ & 2. $B B E-11$ & 2. $88 E-11$ & 2. B日E-11 & 2.88E-11 & 2. BQE-11 & $2.8 E E-11$ & $2.87 E-11$ \\
\hline $10+12 O(g)$ & 5. $91 \mathrm{E}-03$ & $5.91 E-09$ & $3.91 E-09$ & $3.91 \mathrm{E}-09$ & $5.41 E-09$ & $5.91 E-09$ & $5.91 E-\infty$ & $5.91 E-09$ & $5.91 E-09$ \\
\hline (g) & 2. $36 \mathrm{E}-09$ & $2.36 E-09$ & $2.36 E-09$ & $2.36 E-09$ & $2.36 E-09$ & $2.36 E-09$ & $2.36 E-09$ & $2.36 E-09$ & $2.36 E-09$ \\
\hline $34(g)$ & 1.32E-07 & $1.32 \mathrm{E}-07$ & 1.32E-07 & $1.32 E-07$ & $1.32 E-07$ & $1.32 E-07$ & $1.32 \mathrm{E}-07$ & 1. $32 x-07$ & $1.32 E-07$ \\
\hline$(0+11) 2(g)$ & $1.23 E-11$ & $1.39 E-11$ & $1.39 E-11$ & $1.39 E-11$ & 1.39E-11 & $1.39 E-11$ & $1.39 E-11$ & $1.39 E-11$ & $1.39 E-11$ \\
\hline $3+1120(g)$ & 4.12E-07 & $4.12 \mathrm{E}-09$ & 4.12E-09 & $4.12 E-09$ & $4.12 E-09$ & $4.12 E-09$ & $4.12 E-09$ & $4.12 E=09$ & $4.12 E-09$ \\
\hline$i+19$ (g) & $4.3+E-16$ & $4.34 E-16$ & $4.34 E-16$ & $4.34 E-16$ & $4.34 E-16$ & $4.34 E-16$ & $4.34 E-16$ & $4.34 E-16$ & $4.34 E-16$ \\
\hline$(g)$ & 3. $77 E-12$ & $3.39 E-12$ & 3. $39 \mathrm{E}-12$ & 3.39E-12 & 3. 39E-12 & 3. 39E-12 & $3.39 E-12$ & 3. 39E-12 & 3. $39 E-12$ \\
\hline $0(g)$ & $7.77 E-10$ & $7.79 E-10$ & $7.79 E-10$ & $7.79 E-10$ & $7.79 E-10$ & $7.79 E-10$ & $7.79 E-10$ & $7.79 E-10$ & $7.79 E-10$ \\
\hline $13(9)$ & 5. $37 E-05$ & $3.37 \mathrm{E}-0 \mathrm{~s}$ & S. उ7E-O5 & $5.37 E-05$ & 5. 37E-05 & $5.37 \mathrm{E}-0.5$ & $5.37 E-05$ & 5.3TE-05 & $5.37 E-05$ \\
\hline Se $(g)$ & $0 .(\mathrm{NJE}+(\mathrm{CO})$ & $9.31 E-018$ & 4. $75 E-07$ & $1.43 E-06$ & 2. $85 E-06$ & $5.70 E-06$ & $9.51 E-06$ & $1.54 E-05$ & $9.07 \mathrm{E}-05$ \\
\hline $0\langle g\rangle$ & 0. CNJE $+(1)$ & 1. $6^{*}=E-19$ & B. $26 E-19$ & $2.48 E-1 B$ & $4.95 E-18$ & $9.91 E-18$ & $1.6 \mathrm{SE}-17$ & $2.68 E-17$ & 1. $57 \mathrm{E}-16$ \\
\hline $02(g)$ & $0.60, E+10$ & $4.64 E-25$ & 2. $32 E-24$ & $6.96 E-24$ & 1. 3PE-23 & $2.78 E-23$ & $4.64 E-23$ & $7.52 E-23$ & 4. 4$] E-22$ \\
\hline Se $(g)$ & 0. CWE +00 & 4.1.SE -09 & 2. CBE $-0 B$ & $6.23 E-08$ & 1.25E-07 & $2.49 E-07$ & 4.1 DE-07 & $6.73 E-07$ & $3.96 E-06$ \\
\hline
\end{tabular}

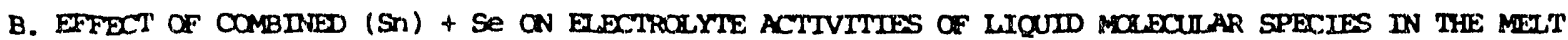

\begin{tabular}{|c|c|c|c|c|c|c|c|c|c|}
\hline $\begin{array}{l}1.120 .03(1) \\
i \text { OH(1) }\end{array}$ & $\begin{array}{l}2.37 E-01 \\
9.15 E-03\end{array}$ & $\begin{array}{l}2.37 E-01 \\
9.15 E-03\end{array}$ & $\begin{array}{l}2.37 E=01 \\
9.15 E-03\end{array}$ & $\begin{array}{l}2.37 E-01 \\
9.15 E-03\end{array}$ & $\begin{array}{l}2.37 E-01 \\
9.15 E-03\end{array}$ & $\begin{array}{l}2.37 E-01 \\
9.15 E-03\end{array}$ & $\begin{array}{l}2.37 E-01 \\
9.15 E-03\end{array}$ & $\begin{array}{l}2.37 E-01 \\
9.15 E-03\end{array}$ & $\begin{array}{l}2.37 E-01 \\
9.15 E-03\end{array}$ \\
\hline Li2se (s) & $0 .(0) E+\infty)$ & $3.12 E-0 \theta$ & $1.56 E-07$ & $4.68 E-07$ & $9.36 E-07$ & 1. $87 E-06$ & $3.12 E-06$ & $5.05 x-06$ & $2.97 E-0.03$ \\
\hline Li30(1) & $1.18 E-06$ & 1. $18 E-0.0$ & $1.18 E-06$ & $1.18 E-06$ & $1.18 E-06$ & 1. $18 E-06$ & $1.18 E-06$ & $1.18 E-06$ & 1. $18 E-06$ \\
\hline$k 2 \cos (1)$ & 7. $47 E-\sigma ?$ & $7.44 E-02$ & 7. $44 E-02$ & $7.44 E-02$ & $7.44 E-02$ & $7.44 E \cdot 0.02$ & $7.44 E-02$ & $7.44 E-02$ & $7.44 E-02$ \\
\hline KOH(1) & 5. $336 E-04$ & $5.06 E-04$ & $5.86 E-04$ & S.E6E-04 & S. $86 E-04$ & $3.86 E-04$ & $5.86 E-04$ & $5.86 E-04$ & $5.86 E-04$ \\
\hline K $2 \mathrm{Se}(\mathrm{s})$ & $0.00 E+(00)$ & $1.60,-199$ & Q.01E-09 & 2. $40 E-08$ & $4.80 E-08$ & $61 E-08$ & $1.60 E-07$ & $2.59 E-07$ & $1.53 E-06-$ \\
\hline $\mathrm{K} 20(1)$ & $1.39 E-15$ & $1.39 E-15$ & $1.39 E-19$ & $1.39 E-1.5$ & $1.39 E-15$ & $1.39 E-19$ & $1.39 E-19$ & $1.39 E-15$ & $1.39 E-15$ \\
\hline Nicos(t) & 2. 16E-09 & $2.16 E-09$ & $2.16 E-09$ & $2.16 E-09$ & 2.16E-09 & $2.16 E-09$ & 2. $16 E-09$ & $2.16 E-09$ & 2. $16 E-09$ \\
\hline$N_{i}(O H) 2(s)$ & $3.30 E=00$ & $3.30 E-08$ & $3.30 E-O B$ & $3.30 E-O B$ & 3. 30E-08 & $3.30 E-08$ & $3.30 E-\infty 8$ & $3.30 E-00$ & 3. $30 E-09$ \\
\hline Nise(s) & $0.0 J E+\infty$ & $9.80 E-0.55$ & $4.90 E-04$ & $1.47 E-03$ & $2.94 E-03$ & 5. $8 B E-03$ & $9.80 E-03$ & $1.5 \% E-02$ & $9.34 E-02$ \\
\hline Nio(1) & $5.18 E-05$ & $5.18 E-05$ & $5.18 E-05$ & 5. $18 E-05$ & $5.18 E-05$ & 5. 1 EE -05 & 5. 1BE-OS & 5. 1EE-0s & 5. $18 E-05$ \\
\hline
\end{tabular}

C. ION FRACTIONS, EFFECT OF $(S n)+$ Se ON IONIC COMPOSITION OF THE MELT, AND ALSO

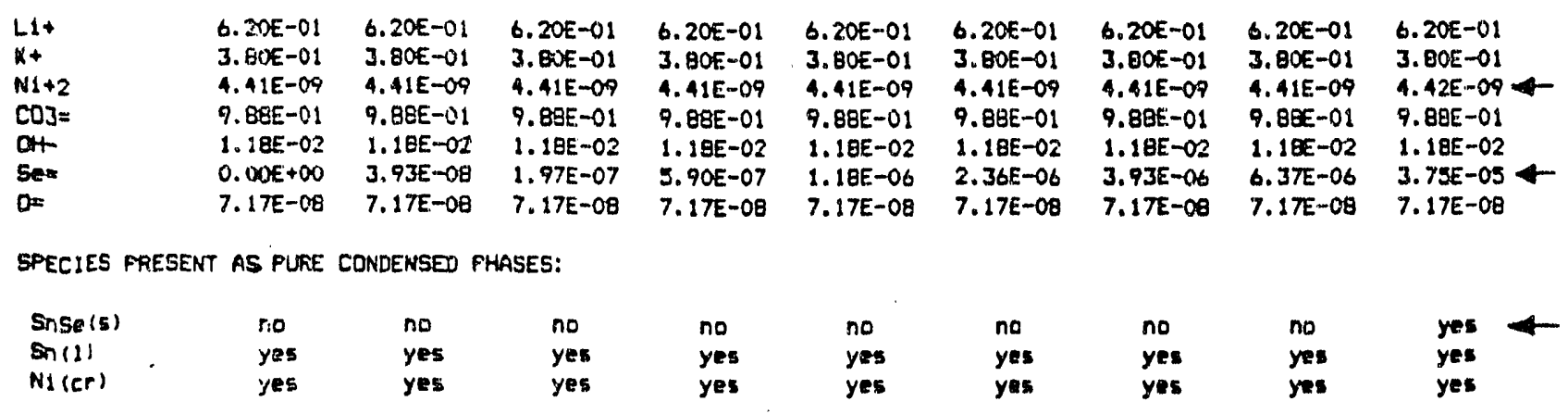


TABLE III•1

A.GAS SPECIES PARTIAL FRESSURES (ATM:

Case: $\quad F b-0 \quad F b-1 \quad P b-2 \quad P b-3 \quad P b-4 \quad F b-5$

\begin{tabular}{|c|c|c|c|c|c|c|}
\hline$N 2(g)$ & $6.00 .1 E-12$ & $6.00 E-02$ & $6.00 E-02$ & $6.00 E-02$ & $6.00 E-02$ & $6.00 E-02$ \\
\hline $02(g)$ & 1.29E-23 & 1. $29 E-23$ & $1.29 E-23$ & $1.29 E-23$ & $1.29 E-23$ & $1.29 E-23$ \\
\hline $\mathrm{H}_{2}(\mathrm{~g})$ & $3.61 \mathrm{E}-(11$ & $3.61 E-01$ & $3.61 E-01$ & $3.61 \mathrm{E}-01$ & $3.61 E-01$ & $3.61 E-01$ \\
\hline $\cos (\theta)$ & $2.0: E-(12$ & 2. $01 E-01$ & $2.01 E-01$ & $2.01 E-01$ & $2.01 \mathrm{E}-01$ & $2.01 E-01$ \\
\hline H2O (3) & $1.73 \mathrm{E}-011$ & $1.79 E-01$ & $1.79 E-01$ & $1.79 E-01$ & $1.79 E-01$ & $1.79 E-O 1$ \\
\hline$(\mathrm{H} 2 \mathrm{O}) 2(\mathrm{~g})$ & $1.95 \mathrm{E}-0 \mathrm{~S}$ & 1.95E-05 & 1.95E-05 & 1.95E-05 & $1.95 E-05$ & 1.95E-0J \\
\hline $\operatorname{col}(g)$ & 1.9?E-01 & $1.99 E-01$ & $1.99 E-01$ & $1.99 E-01$ & $1.99 E-01$ & $1.99 E-01$ \\
\hline L1마i(g) & $9.62 \mathrm{E}-05$ & $9.62 E-09$ & $9.62 \mathrm{E}-09$ & $9.62 E-09$ & $9.62 E-09$ & $9.62 E-09$ \\
\hline$(L I O H) Z(g)$ & $2.88 E-11$ & 2. BBE-11 & $2.89 E-11$ & 2. BBE-11 & $2.88 E-11$ & $2.88 E-11$ \\
\hline$L 1 O L: H 2 O(g)$ & $5.9: E-017$ & $5.91 E-0 \%$ & $5.71 E-09$ & $5.91 E-09$ & $5.91 E-09$ & $5.91 E-09$ \\
\hline$K(g)$ & $2.36 E-(19)$ & $2.36 E-09$ & $2.36 E-09$ & $2.36 E-09$ & $2.36 E-09$ & $2.36 E-09$ \\
\hline$K O H(g)$ & 1. $32 \mathrm{E}-07$ & 1. 32E-0\% & 1.32E-07 & $1.32 E-07$ & 1. $32 E-07$ & 1.32E-07 \\
\hline$(1.011) 2(g)$ & 1.37E-11 & 1. 39E-11 & 1. J9E-11 & 1. $39 E-11$ & $1.39 E-11$ & $1.39 E-11$ \\
\hline $\mathrm{KOHH} / 2 \mathrm{O}(\mathrm{g})$ & 4. $12 \mathrm{E}-09$ & 4. $12 E-09$ & 4.12E-09 & 4. 12E-09 & $4.12 E-09$ & $4.12 E-09$ \\
\hline PtH $(g)$ & $0.00 E+00$ & $2.06 E-11$ & $1.03 E-10$ & $2.06 E-10$ & $4.12 \mathrm{E}-10$ & $5.26 E-10<-$ \\
\hline$P t(g)$ & $0.00 \mathrm{~J} E+00$ & $9.99 E-08$ & $5.00 E-07$ & 9. 99E-07 & $2.00 E-06$ & 2. $\pi 5 E-06-$ \\
\hline$P t 2(3)$ & $0.05 E+00$ & 3.55E-15 & $8.875-14$ & $3.55 E-13$ & 1. $42 E-12$ & $2.32 E-126$ \\
\hline$P B O(g)$ & $0.00 E+00$ & 4. $02 E-19$ & $2.01 E-13$ & $4.02 E-13$ & B. OSE-13 & $1.03 E-12-$ \\
\hline $\mathrm{NH} 3(\mathrm{~g})$ & $5.37 E-15$ & $5.37 E-05$ & $5.37 \mathrm{E}-05$ & $5.37 E-05$ & $5.37 E-05$ & $3.37 E-05$ \\
\hline
\end{tabular}

B.EFFECT ON ELECTROLYTE ACTIVITIES OF TRACE SPECIES IN MELT

\begin{tabular}{|c|c|c|c|c|c|c|}
\hline L12r:03(1) & 2. 37E-01 & 2. $37 E-01$ & $2.37 E-01$ & $2.37 E-01$ & $2.37 E-01$ & $2.37 E-01$ \\
\hline $\mathrm{LiOH}(1)$ & $9.15 E-03$ & $9.15 E-03$ & $9.15 E-03$ & $9.15 E-03$ & $9.15 E-03$ & $9.155-03$ \\
\hline $\operatorname{Li2n}(1)$ & 1. $19 E-0.6$ & $1.16 E-16$ & 1. 18E-O6 & 1. $18 E-06$ & $1.18 E-06$ & $1.18 E-06$ \\
\hline$k 2 \cos (1)$ & $7.44 E-0.2$ & $7.44 E-02$ & $7.44 E-02$ & $7.44 E-02$ & $7.44 E-02$ & $.44 E-02$ \\
\hline $\mathrm{KOH}(1)$ & 5. $136 E-04$ & $5.86 E-1.24$ & 5. BSE-04 & $5.86 E-04$ & 5. B6E-04 & $5.86 E-04$ \\
\hline$k 20(1)$ & 1. $39 E-15$ & 1. $39 E-15$ & $1.39 E-15$ & $1.39 E-15$ & $1.39 E-15$ & $1.39 E-15$ \\
\hline $\mathrm{NiCO} 3(1)$ & 2. $16 E-09$ & $2.16 E-1) 9$ & $2.16 E-09$ & $2.16 E-09$ & $2.16 E-09$ & $2.165-09$ \\
\hline $\mathrm{Ni}(\mathrm{OH}) 2(5)$ & $3.30 E-08$ & 3. 30E-08 & $3.30 \mathrm{E}-08$ & 3. $30 E-O B$ & $3.30 E-08$ & $3.30 E-08$ \\
\hline NiO(1) & 5. $18 E-05$ & 5. $18 E-1) 5$ & 5. $18 E \cdots 05$ & 5. $18 \mathrm{BE}-05$ & $5.18 E-05$ & $5.18 E-05$ \\
\hline $\mathrm{PbCO}_{3}(\mathrm{~s})$ & $0.00 E+010$ & 1. $.08 E-09$ & $5.42 E-09$ & $1.08 E-08$ & 2.17E-OQ & $2.77 E-08 \leftarrow$ \\
\hline $\mathrm{Fb}(\mathrm{OH}) 2(\mathrm{~s})$ & $0.00 E+00$ & $1.9 ! E-12$ & $9.53 E-12$ & $1.91 E-11$ & 3. $81 E-11$ & $4.87 E-11 Q$ \\
\hline $900(1)$ & $0.00 E+00$ & $1.11 E-06$ & $5.55 E-06$ & $1.11 E-05$ & $\therefore 22 E-05$ & $2.94 E-05$ \\
\hline
\end{tabular}

C. EFFET ON IONIC COMPOSITION OF THE MEIT

$\begin{array}{lllllll}\mathrm{Li}+ & 6.20 E-011 & 6.20 E-01 & 6.20 E-01 & 6.20 E-01 & 6.20 E-01 & 6.20 E-01 \\ \mathrm{~K}+ & 3.80 E-01 & 3.80 E-01 & 3.80 E-01 & 3.80 E-01 & 3.80 E-01 & 3.80 E-01 \\ \mathrm{Ni}+2 & 4.41 E-09 & 4.41 E-09 & 4.41 E-09 & 4.41 E-09 & 4.41 E-09 & 4.41 E-09 \\ \mathrm{Fb}+2 & 0.00 E+00 & 2.02 E-09 & 1.01 E-01 & 2.02 E-08 & 4.04 E-08 & 5.16 E-08- \\ \mathrm{CO}= & 9.8 B E-01 & 9.8 B E-01 & 9.88 E-01 & 9.8 B E-01 & 9.88 E-01 & 9.88 E-01 \\ \mathrm{OH}- & 1.18 E-02 & 1.18 E-02 & 1.18 E-02 & 1.18 E-02 & 1.18 E-02 & 1.18 E-02 \\ 0= & 7.17 E-0 B & 7.17 E-08 & 7.17 E-08 & 7.17 E-08 & 7.17 E-0 B & 7.17 E-08\end{array}$

SFECIES PRESENT AS PURE COTIDENSED PHASES:

$\begin{array}{lllllll}\text { Pt (1) } & \text { no } & \text { no } & \text { no } & \text { no } & \text { no } & \text { yes } \\ \text { NI (cr) } & \text { yes } & \text { yes } & \text { yes } & \text { yes } & \text { yes } & \text { yes }\end{array}$


TABLE III*2

A. RAS EPECIES FAFTIAL PRESTPSS (ATM)

\begin{tabular}{|c|c|c|c|c|c|c|}
\hline Case: & $P(t)=0$ & $P t D-1$ & $P_{b}-2$ & Po - & PD - & Pb - \\
\hline$N 2(\theta)$ & 6. CKEE-02 & 6. $00 \mathrm{cos}-1) 2$ & $0.00 E-02$ & b. $00 E-02$ & $6.00 E-02$ & $6.00 E-02$ \\
\hline $2(g)$ & 1. $7 \%-23$ & 1. $29 E-23$ & $1.29 E-23$ & $1.29 E-23$ & $1.29 E-23$ & $1.28 E-23$ \\
\hline$(8)$ & 3. $A: E-01$ & J.61E-11 & 3.018 .01 & $3.63 E-01$ & $3.61 E-01$ & $3,41 E \cdot-01$ \\
\hline$C 12(g)$ & $1.25 x-27$ & $1.25 E-21)$ & 1. $2 \approx E-27$ & $1.25 E-27$ & $1.25 E-27$ & $1.25 E-27=$ \\
\hline $22(g)$ & $2 .(1 ! E-0)$ & $2.01 E-01$ & $2.01 E-01$ & $2.01 E-(1) 1$ & $2.01 E-01$ & $2.01 E=01$ \\
\hline $20(g)$ & $1.7 \pi-01$ & $1.79 E-01$ & $1.79 E-01$ & $1.795=01$ & $1.79 E-01$ & 1.798 .01 \\
\hline$(120) 2(g)$ & $1.05 E-0_{0}^{*}$ & $1.95 E-0 \%$ & $1.93 x-05$ & 1. $9 \mathrm{DE}$ & 1.95E-OS & $1.4560 \mathrm{~s}$ \\
\hline$D(g)$ & $1.700-01$ & $1.99 E-01$ & 1, POE -01 & $1.49 E-01$ & $1.94 E-01$ & $1.995-01$ \\
\hline $0:(g)$ & $9.62 E-09$ & $9.62: E-09$ & 9. 6.) 0 - 09 & $9.62 E-09$ & $9.625-09$ & $9.62 E-09$ \\
\hline (LON) $2(9)$ & 2. $87 E-11$ & $2.87 E \cdots 11$ & 2. ETE-11 & $2.87 E-81$ & $2.87 E-11$ & $2.8 \mathrm{rE}-11$ \\
\hline $10=120(8)$ & $5.91 E=09$ & $5.91 E-09$ & $3.91 E-09$ & $3.91 E-09$ & $5.91 E-09$ & $3.91 E-09$ \\
\hline $\operatorname{LICl}(g)$ & $1.05 t-109$ & $3.05 E .09$ & 1. 0ose -09 & $1.005-09$ & $1.05 E-09$ & $1.0 \$ E-09$ \\
\hline$(g)$ & $2.55 E-07$ & $2.35 E-18$ & 2. JEE -09 & $2.535-09$ & 2. 35E-09 & 2. J5E-09 \\
\hline$x(g)$ & 1. 3IE- -17 & $1.31 E-04$ & $1.31 E-07$ & $1.315-07$ & $1.31 E-0 \%$ & $1.31 E-07$ \\
\hline$(x O H) 2(g)$ & 1. $2 T E-11$ & $1.375-11$ & $1.37 t-11$ & $1 . \pi 7 E-11$ & $1.376-11$ & $1.37 E-11$ \\
\hline$x 00120(8)$ & 4. तPE-OP & $4.09 E-09$ & $4.095-09$ & $4.09 E-09$ & $4.09 E \cdot 09$ & $4.095-09$ \\
\hline $\operatorname{KCJ}(\theta)$ & $2.285-07$ & $2.28 \mathrm{E}-07$ & 2. $\angle B E-O 7$ & 2. 3BE-07 & $2.285-07$ & 2.2BE -07 \\
\hline (C) $(g)$ & 6. 10世-19 & 6. $10 E-19$ & 1. $10 \%-19$ & A. $10 E-19$ & $6.10 E-19$ & $6.106-19$ \\
\hline $11 C 12$ (g) & 2. $: 14 E-21]$ & $2.24[-.21$ & $2.24 E-21$ & 2.2AE-21 & $2.24 E-21$ & $2.24 E-21$ \\
\hline$C . I(g)$ & $0 .(r . E+(10)$ & $1.90 E-12$ & $9.49 E-12$ & $1.90 E-11$ & $3.795-11$ & 4. BDE-11 - \\
\hline$[12(g)$ & $0 . P 2, E=+\infty 0$ & $9.70 E-18$ & $2.855-17$ & $3.70 E-17$ & $1.14 E-16$ & $1.46 \mathrm{E}-16 \div$ \\
\hline$C 14(g)$ & $0.010 .6+00)$ & $-1,33 E-36$ & $6.63 E-36$ & 1. J3E-3E & $2.65 E-3 \pm$ & $3.39 E-35 \div$ \\
\hline$H(y)$ & 0$. (rite $+C x)$ & $2.06 E-11$ & $1,0.35-10$ & $2.06 E-10$ & $4.12 E-10$ & $=.26 E-10 \leftarrow$ \\
\hline$(g)$ & $0 .(r$, 此小) & $9.99 \mathrm{E}-018$ & $\$ .00 E-07$ & $9.99 E-07$ & $2.00 E \sim 06$ & $2.5 x t-06$ \\
\hline $2(8)$ & $0 .(n, D E+\infty)$ & $3.55 E-15$ & B. B7E-14 & ] $.55[-13$ & 1. $42 E-12$ & $2.32 E-12 \leftarrow$ \\
\hline$(g)$ & $0.1 \times, E+\infty O$ & $4.02 E-14$ & $2.01 E-13$ & $4.025-13$ & 6. OSE-13 & $1.03 E-12$ \\
\hline $13(g)$ & $5.275-0 \%$ & 3. 37E -0.5 & S. J7E-OE & \$. J7E-OE & $5.37 E-0.5$ & $5.37 E-05$ \\
\hline$[l(g)$ & 1.C.1E-OB & $1.01 E-08$ & $1.01 E=08$ & $1.01 E-018$ & $1.01 E-03$ & $1.01 E-08$ \\
\hline
\end{tabular}

B. EFFECTS OF COMEINED Pb + Cl ON ELECTROLYTE ACTIVITIES

\begin{tabular}{|c|c|c|c|c|c|c|}
\hline & & & & & & \\
\hline $412 \cos (1)$ & 2. JTE-DI & $2.37 E, 01$ & $2.37 \mathrm{E}-01$ & $2.37 E-01$ & 2. $37 E-01$ & $2.376-01$ \\
\hline LIOM(I) & $9.15 E-0.3$ & $9.15 E-13$ & $9.15 E-03$ & $9.15 E-03$ & $9.15 \mathrm{E}-03$ & $9.15=-03$ \\
\hline Licl(d) & 3."1?E-05 & 3. $07 E-45$ & $3.07 E-05$ & 3.07E-05 & $3.07 t-05$ & $3.07 E-05$ \\
\hline Lizilli & 1. 1TE-OQ & $1.17 E-.6$ & $1.17 E=0.6$ & $1.17 E_{n}-06$ & $1,17 E=06$ & $1.17 \mathrm{E}-06$ \\
\hline $42003(1)$ & $7.32 E-02$ & 7. $32 E-02$ & 7. 32E $=02$ & $7,32 E-02$ & $9.32 k-02$ & 7. $.22 E-02$ \\
\hline$x(0 \times 11)$ & 5. $8.2 E-04$ & 5. $42 E-04$ & 5. $822 E-04$ & $5.62 E-04$ & $5.02 E-04$ & 5. $12 \mathrm{E}-04$ \\
\hline$x(t)(1)$ & $9.5 B E-03$ & $4.58 E-0,3$ & $9.58 E-03$ & $9.59 E-03$ & $9.58 E-0.3$ & $9.5 a E-03$ \\
\hline$k 20(1)$ & 1.3.E-1.5 & $1.37 E-15$ & 1. J7E-15 & 1. J7E-15 & $1.37 E-15$ & $1.375-15$ \\
\hline Nicos(1) & 2.1 AE -09 & $2.16 \mathrm{E}+109$ & $2.16 E=09$ & 2. $16 E-09$ & $2.16 E-09$ & $2.165-09$ \\
\hline $\mathrm{Ni}(\mathrm{NK}) 2(\mathrm{~s})$ & 3. $2115-C \theta$ & 3. $3(1,5-26$ & 3. $30 E-08$ & $3.30 E=08$ & $3.30 E-O B$ & 3. $30 E-08$ \\
\hline NACI2 (1) & $2.04 E-19$ & 2. (1)E-19 & $2.04 E-19$ & $2.04 E-19$ & $2.04 E-19$ & 2.04E-19 \\
\hline NiOC(1) & 5. $19 E-05$ & 5. 18E-0.5 & 5. 1BE-OS & $5.18 E-0.5$ & $5.16 E-05$ & $5.101:-05$ \\
\hline $\operatorname{POCO} 3(\mathrm{~s})$ & $0.1 \times . E+(x)$ & $1.08 E-09$ & $3.42 E-09$ & $1.00 E-00$ & $2.17 E \cdots 08$ & $2.77 E-08$ \\
\hline$P 0(O N) 2(5)$ & $0 .(\mathrm{M}) \mathrm{E}+(\mathrm{x})$ & $1.91 E \cdot 12$ & $7.5 J E-12$ & $1.91 E-11$ & 3. B1E-11 & $4.87 E-11-0$ \\
\hline$b C 12(1)$ & $0.1 m \times E+\infty 0$ & 4. $33 E-16$ & $2.17 E-15$ & $4.33 E-15$ & Q. $6 \Delta E-15$ & $1.11 E-14$ \\
\hline$D D(1)$ & $0 .(x)+(x)$ & 1. $11 E-0) 6$ & 3. 5EE-06 & 1.11E.\$5 & $2.22 E-05$ & $2.04 E-05<$ \\
\hline
\end{tabular}

C. EFEETS ON IONIC CONPOSITION OF TUE MRLT

\begin{tabular}{|c|c|c|c|c|c|c|}
\hline LIt & b. "2VE -01 & $4.20 E-01$ & 6. 2C)E - 01 & $0.20 E-01$ & $0.20 E-01$ & $0.20 E-01$ \\
\hline$x$ & 3. BiE -01 & $3.80 E-01$ & 3. QCE -01 & 3. BOE-OI & 3. BOE-OI & $3.80 t-01$ \\
\hline $\mathrm{Ni}+2$ & 4. 47E-07 & $4.47 E-\infty 9$ & $4.47 E-09$ & $4,17 E-09$ & $4.47 E-09$ & $4.47 E-69$ \\
\hline $\begin{array}{l}\mathrm{PlD+2} \\
\mathrm{m} 3=\mathrm{F}\end{array}$ & $\begin{array}{l}0 .(x)=00 \\
0.86 E-01\end{array}$ & $\begin{array}{l}2.03 E-0.9 \\
9.8,5 E-01\end{array}$ & $\begin{array}{l}1.02 E-08 \\
9 . B G E-01\end{array}$ & $\begin{array}{l}\text { 2. } 03 E-009 \\
9.8+5=-01\end{array}$ & $\begin{array}{l}4.06 E-08 \\
9.86 E-01\end{array}$ & $\begin{array}{l}5.19 E-08<- \\
9.8 A E-01\end{array}$ \\
\hline at+ & 1. $100-02$ & 1. 1 - -12 & 1. $10 E-02$ & 1. $10 E-02$ & 1. 18E-02 & 1. $1 \mathrm{BE}-02$ \\
\hline C.: & 1. $\operatorname{ces}=-13$ & $\therefore$ EBE- OJ & 1. DOE - 07 & 1. $88 E-03$ & 1. $8 B E-03$ & 1. BRE -03 \\
\hline $0=$ & $7,18 x-06$ & $7.1135<-0 \mathrm{~B}$ & 7.1 GE $-0 B$ & $7.18 E-\infty 0$ & 7. $1 B E-C B$ & $7.1 \mathrm{EE}-\mathrm{OB}$ \\
\hline
\end{tabular}

SRECIES PRESENT RS PUAR: CORLEIVSEL PHASES:

$\begin{array}{lllllll}P 0111 & \text { nio } & \text { No } & \text { no } & \text { no } & \text { no } & \text { yes } \\ \text { N1(6) } & \text { yes } & \text { yes } & \text { yes } & \text { yes } & \text { yes } & \text { yes }\end{array}$


TABLE III• 3

A. SAS SPECIEg PARTIAL PRESSIARES (ATM)

\begin{tabular}{|c|c|c|c|c|c|c|}
\hline Case: & $P_{t}-0$ & $P D-1$ & Po - & $P b-$ & $P D=$ & Po - \\
\hline 9) & 5. $96 E-02$ & $5.99 E--22$ & $9.48 E-02$ & $5.98 t-02$ & 5. $98 E-02$ & $3.98 E-02$ \\
\hline 91 & $1.32 E-23$ & $1.32 E-23$ & 1. $32 E-23$ & $1.32 F-23$ & $1.32 E-2 J$ & $1.32 \mathrm{E}-2 \mathrm{~J}$ \\
\hline 91 & 3. $60 E-01$ & $3.60 E-01$ & $3.00 E-01$ & $3.60 E=01$ & 3. $60 E-01$ & 3. $106-01$ \\
\hline (g) & 1. $2 \pi E-23$ & $1.2 \pi E-23$ & $1.27 \mathrm{E}-23$ & $1.27 t-23$ & 2. $27 E-23$ & $1.27 \mathrm{E}-23$ \\
\hline (8) & $2.02 \pi=01$ & $2.02 z-01$ & $2.02 E-01$ & $2.027-01$ & $2.02 E-01$ & $2.02 E-01$ \\
\hline & 1. DUE-01 & $1.80 \varepsilon-01$ & 1. BOE-OI & $1,80 E-01$ & 1. $80 E-01$ & 1. BOE-OI \\
\hline $1112(g)$ & 1. $78 E-05$ & $1,98 E-05$ & 1. $9 \mathrm{se}-05$ & $1.98 k-05$ & $1.98 E-05$ & $1.98 E-05$ \\
\hline & $1.98 E-01$ & $1.98 E-01$ & $1.98 E-01$ & $1.99 F-01$ & 1. PQE-OI & $1.98 E-01$ \\
\hline (g) & $9.0 \pi-\infty 9$ & $9.07 \varepsilon-\infty$ & $9.07 \mathbb{E}-09$ & $9.07 E-09$ & $9.07 E-04$ & P.DTE-OQ \\
\hline DAl? & 2. $55 E-11$ & $2.55 E-11$ & 2. SSE-11 & $2.55 t-11$ & $2.55 E-11$ & 2. SSE- 11 \\
\hline $\tan 2$ & 5. $60 \varepsilon-09$ & $5.600-09$ & 5. $60 E-09$ & $5.60 E-09$ & $5.60 E-09$ & $5.60 E-09$ \\
\hline $1(g)$ & $9.92 \varepsilon-\infty 8$ & $9.92 E-08$ & 1. TRE-00 & $9.72 F-09$ & $9.42 E-08$ & $9.92 E-0 B$ \\
\hline & $1.19 E-199$ & $1.19 E-09$ & 1. 19E-09 & $1.19 E-09$ & $1.19 E-04$ & $1.19 E-09$ \\
\hline (g) & $0.67 E-0.8$ & $0.67 E-00$ & $6.67 E-08$ & $6.675 i-08$ & $6.67 E-00$ & $6.67 E-O B$ \\
\hline H) $2(\theta)$ & 3. $56 E-12$ & J.5BE-12 & 3. $34 E-12$ & $3.56 E-12$ & $3.36 E-12$ & $3.56 E-12$ \\
\hline$+120(g)$ & $2.10 E-119$ & $2.10 E-04$ & $2.10 E-09$ & 2. 10E-09 & $2.105=09$ & $2.10 E-09$ \\
\hline$(g)$ & $1.17 E-05$ & $1.17 \mathrm{E}-0 \mathrm{~s}$ & 1. 17E-OS & 8.1TE-OS & 1.17E-05 & $1.17 E-09$ \\
\hline$l(g)$ & $0.15 E-17$ & $0.15 E-17$ & $6.15 E-17$ & $6.15 t-17$ & $6.15 E-17$ & $0.15 E-17$ \\
\hline $12(g)$ & $2.29 E-17$ & $2.28 E-17$ & 2. $20 E-17$ & $2.28 E-17$ & $2.28 E-17$ & $2.2 B E-17$ \\
\hline & $0, x) E+\infty$ & $1.7 D E-10$ & $9.52 E-10$ & $1,906-09$ & $3.81 E-09$ & $4,89 E-09$ \\
\hline & $0.1 X Y E+D)$ & $5.77 E-14$ & 2. E9E- 13 & $5.77 t-13$ & 1. $15 E-12$ & $1.48 E-12=$ \\
\hline $14(g)$ & $0.1 m e+00$ & $1.37 E-20$ & $6.83 E-2 B$ & 1. J7E-27 & $2,73 E-27$ & $3.51 t-27-$ \\
\hline$(g)$ & $0.0 N E+\infty 0$ & $2.04 E-11$ & $1.02 E-10$ & $2.04 E-10$ & $4.095-10$ & $5.25 E-10<$ \\
\hline gi & 0.1 NCE $+\infty 0$ & $9.93 E-08$ & 4. $97 E-07$ & $9.93 E-07$ & $1.99 E-06$ & 2.:5E-06 \\
\hline Ig & $0 .(x) E+\infty$ & $3.51 E-15$ & B. $\pi E-14$ & $3.31 E-1.3$ & $1.40 E-12$ & $2.32 E-12$ \\
\hline (g) & 0.1 INE $+\infty 0$ & $4.0 .4 E-14$ & $2.025-13$ & $4.04 E-13$ & B. $07 E-13$ & $1.04 E-12$ \\
\hline (g) & S. 3CE-0S & 3. 34E-OS & $5.34 E-05$ & 5.J4E-0.5 & $5.34 E-05$ & $5.34 E-05$ \\
\hline (g) & $1.025-06$ & $1.02 E-06$ & $1.02 E-06$ & $1.02 F-06$ & $1.07 E-06$ & $1.02 E-06$ \\
\hline
\end{tabular}

B. EFFECTS OF COMBYNED F'b + Cl ON ELECTROLXTE ACTIVITIES

\begin{tabular}{|c|c|c|c|c|c|c|}
\hline $\begin{array}{l}\operatorname{Li} 203(1) \\
\text { Loth(1) } \\
\text { Lifl(1) }\end{array}$ & $\begin{array}{l}2.11 E-01 \\
E .62 E-03 \\
2.80 E-03\end{array}$ & $\begin{array}{l}2.11 E-01 \\
8.62 E-03 \\
2.90 E-03\end{array}$ & $\begin{array}{l}\text { 2.11E-01 } \\
8.22 E-03 \\
2 . \$ 0 E-03\end{array}$ & $\begin{array}{l}2.11 E-01 \\
8.62 E-0] \\
2.90[-0]\end{array}$ & $\begin{array}{l}2.11 E-01 \\
0.62 E-03 \\
2.90 E-0 .]\end{array}$ & $\begin{array}{l}2.11 E-01 \\
0.62 E-03 \\
2.90 E-03\end{array}$ \\
\hline$(220(1)$ & $1.04 E-06$ & 1.04E- 04 & 1. CAAE $-O_{6}$ & 1. OAE-0E & 1.02E-06 & $1.04 E-06$ \\
\hline$(2 \cos (1)$ & $1.91 E-02$ & $1.915 \times 02$ & $1.91 \mathrm{E}-02$ & $1.91 \mathrm{E}-02$ & $1.91 E-U 2$ & $1.91 E-02$ \\
\hline$x$ an (1) & $2.97 E-04$ & $2.97 \equiv<14$ & $2.97 E-0.4$ & $2.97 E-0.4$ & $2.97 E-04$ & $2.97 E-0.4$ \\
\hline$x C 1(1)$ & 4. $9912-01$ & $4.90 E-01$ & 4. $90 E-01$ & $4.905-01$ & $4.90 E-01$ & $4.90 E-01$ \\
\hline$\times 20(1)$ & 3. SSE-16 & 3. ESE-16 & $3.5 \mathrm{ES} \cdot 16$ & 3. $550-16$ & 3. $5.0-16$ & $3.5=5-16$ \\
\hline Nicol(1) & $2.19 E-09$ & $2.19 E-19$ & $2.19 E-09$ & 2. $19 E-09$ & $2.19 E-09$ & $2.19 E-09$ \\
\hline$N_{1}(O H) 2(s)$ & 3. $3 \pm E-03$ & J. 3EE- 08 & 3. TEE-08 & 3. 35T-65 & $3.35 E-68$ & 3. 35E- 08 \\
\hline NiCl2 (1) & $2.08 E-15$ & $2.08 E-15$ & 2. $\operatorname{CAE}-15$ & 2. $0 B E-15$ & $2.08 E-15$ & $2.0 \mathrm{EE}-1 \mathrm{~J}$ \\
\hline NIO(I) & $5,225-05$ & 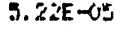 & $5.21 E-0 \%$ & $5.2 Z E-05$ & $5.22 E-05$ & a.22E-0.5 \\
\hline $\operatorname{Ptcos}(s)$ & $0.1 \times 0,000$ & $1.09 E-09$ & $5.46 E-09$ & 1. $69 E-08$ & 2.19E-OB & $2.91 E-C B$ \\
\hline$F(D+1) 2(5)$ & U. (K.E+(k) & $1.92 E-12$ & 9.tIE-12 & $1.92 E-11$ & 3. BAE-11 & $4.94 E-11$ \\
\hline $0(1211)$ & $0.0 \Delta E+\infty x$ & $1.38 E-12$ & $2.19 E-11$ & $4.38 E-11$ & - $.77 \mathrm{E}-11$ & $1.17 E-10$ \\
\hline Pto(1) & $0.0 \times E E+\infty 0$ & $1.11 E-16$ & 5.57E-06 & $1, d 1 E-0 \equiv$ & $2.23 E-015$ & $2.86 E-05$ \\
\hline
\end{tabular}

\section{EPFECTS ON IONIC COMPOSIYYON OP TBE MELT}

\begin{tabular}{|c|c|c|c|c|c|c|}
\hline L.t4 & 6. $20 E-01$ & $6.20 E-01$ & D. $20 \mathrm{E}-02$ & $6.20 E-01$ & 6. $20 E-01$ & $6.20 E-01$ \\
\hline$k+$ & 3. $(8 x+5=01$ & $3.80 E-11$ & 3. $00 E-01$ & $3 . B O E-O 1$ & $3.805=01$ & 3. $80 \mathrm{E}-0 !$ \\
\hline$N 1+2$ & 1. 44E. & $1.44 E-1 B$ & $1.44 E-00$ & $1.44 E-00$ & $1.44 E-08$ & $1.44 E-0 Q$ \\
\hline$P D+2$ & $0.000+00$ & 3. उ7E -09 & $1.69 E-00$ & 3. J7E- -00 & $6.74 E-08$ & $8.67 E-6 B$ \\
\hline $003=$ & 1. $36 E-01$ & 8. 3AE -01 & $0.36 E-01$ & อ. $365-01$ & $0.36 E-01$ & B. $3 \in E-0 i$ \\
\hline$a+$ & 1. $26 E-02$ & $2.26 E-02$ & $1.26 E-02$ & $1.26 E-0 . ?$ & $1.26 E-02$ & 1.26E-02 \\
\hline Cl:- & 1.31E-01 & $1.31 E-01$ & 1. $\$ 1 E-01$ & 1. SIE-01 & $1.51 E-01$ & $1.31 E-01$ \\
\hline $0 *$ & B. YUE - OE & $9.90 E<C B$ & 1. $90 \varepsilon-00$ & $0.90 E-00$ & $8.90 E-08$ & $0.90 E-00$ \\
\hline
\end{tabular}

SPECIES PAESENT AS PURE COHERSE PAASES:

\begin{tabular}{|c|c|c|}
\hline $\begin{array}{l}P t(1) \\
N 1(\text { (S) }\end{array}$ & $\begin{array}{l}n=1 \\
y \in s\end{array}$ & $\begin{array}{l}\text { no } \\
\text { yes }\end{array}$ \\
\hline
\end{tabular}


IABLE III•4

A. GAS SDECIES PART! HL PRESSLRES (ATM)

\begin{tabular}{|c|c|c|c|c|c|c|}
\hline Cane: & $P_{D}=0$ & $P D-1$ & $A D=2$ & $P D-3$ & $\mathrm{~Pb}-$ & $P D=$ \\
\hline & b. $\cos \int-12$ & $6.00 E=02$ & $1.00 E-02$ & b. $00 t-02$ & $6.00 \mathrm{E}=02$ & $6.00 E-02$ \\
\hline & $1.7 \times 0-23$ & $1.29 E-23$ & $1.29 t-23$ & $1.29[-23$ & $1.29 E-23$ & $1.29 E-23$ \\
\hline & $3,6 ! E-01$ & $3.61 E-01$ & 3. $41 E=01$ & 3.61E-01 & $3.61 E-01$ & $3.61 E-01$ \\
\hline B) & 7.57E-17 & $7.5 \%-17$ & $7 . \sec -17$ & $7.37 E-17$ & $7.55 E-17$ & $7.54 E-17 \sim$ \\
\hline$(g)$ & 2. $01 E-01$ & 2.01E-01 & $2.01 E-01$ & 2.01E-01 & $2.01 E-01$ & $2.01 E-01$ \\
\hline$(g)$ & $1.79 E-01$ & $1.74 E-01$ & $1.79 E-01$ & $1.79 z-01$ & $1.79 E-01$ & $1.795-01$ \\
\hline (D) $2(g)$ & $1.95 E-\infty 3$ & $1.958-05$ & 1. $95 E-05$ & $1.95[-\infty$ & $1.955-05$ & $1.45 E-03$ \\
\hline & $1.9 \%=01$ & $1.99 E-01$ & $1.99 t-01$ & $1.99 E-01$ & 1. P9E-01 & $1.99 E-01$ \\
\hline & $9,62 E-09$ & $9.62 E-09$ & $9.62 E-09$ & $9.62 E-09$ & $9.67 E-09$ & $9.62 E-09$ \\
\hline क्या $2(g)$ & 2. $\operatorname{EOE}-11$ & 2. $\operatorname{BRE}-11$ & 3. $B A E-11$ & 2. $8 B E-11$ & $2.8 B E-11$ & 2. $88 E-11$ \\
\hline $0420(9)$ & $3.91 E-09$ & $5.915-09$ & $3.91 E-09$ & $5.91 E-09$ & 5. 9\&E-09 & $3.91 E-09$ \\
\hline & 2. $365=-09$ & $2.36 E-0,7$ & $2.365-09$ & $2.365,-04$ & $2.36 E-09$ & $2.36 E-09$ \\
\hline $1(g)$ & $1.32 E-07$ & $1.32 \mathrm{E}$ & 1. IZE-07 & $1.32 E-07$ & 1. $32 \mathrm{X}-07$ & 1.32E -07 \\
\hline iा $2(g)$ & 1. $3 F E-11$ & 1. J9E-: & $1.39 E-11$ & $1.39 E-11$ & $1.39 E-11$ & $1.34 E-11$ \\
\hline $120(9)$ & $4.12 E-09$ & $4.12 E-09$ & $4.12 E-09$ & 4.12f -09 & $4.12 E-09$ & $4.12 E-09$ \\
\hline$(g)$ & 1. BBE -OB & 1. $8 B E-O B$ & 1. EBE $-0 \theta$ & $1.805-08$ & $1.8 B E-0 B$ & $1.87 E-08-$ \\
\hline 19$)$ & 0. cose +00 & $2.06 E-11$ & $1.03 E-10$ & $2.06 E=10$ & $4.11 E-10$ & $5.26 E-10<$ \\
\hline & $0 .(\omega) E+\infty)$ & $9.9 Q E-O B$ & $4.995-07$ & $9.98 E-07$ & $2.00 E-0 b$ & 2.55E-06 - \\
\hline & $0 .(N, E)+\infty$ & $3.54 E-15$ & 9. $85 E-14$ & $3.5 A E-13$ & $1.42 E-12$ & $2.3 Z E-12$ \\
\hline & 0. CNEE $+\infty$ & $1.37 E-10$ & 6. $24 E-10$ & $1.37 E-09$ & $2.733 E-0.9$ & $3.49 E-09-$ \\
\hline & $0,(Y) E+\infty)$ & $4.02 \mathrm{E}-14$ & $2.01 E-13$ & $4.02 E-13$ & B. OAE-13 & $1,03 E-12<$ \\
\hline & E. בTE-CE & $5.37 E-05$ & 5. J7E-OS & $5.37 E$ ․․ & 5. 37E-05 & $5.37 \mathrm{E}-05$ \\
\hline & 1. CITE-Ub & $1.07 E-06$ & $1.07 E-06$ & 1. OTE-OS & $1.07 E-06$ & $1.07 \mathrm{E}-06$ \\
\hline
\end{tabular}

B. EPFECTS OF COMBIHED PL + S ON ELECTROLYTE ACTIVITIES

\begin{tabular}{|c|c|c|c|c|c|c|}
\hline$b+2<0$ & $.37 E-01$ & 2.37E-(1) & $2.37 E-01$ & 2. JTE-O1 & $2.37 \mathrm{E}-01$ & 2. J7E-OI \\
\hline $1.10+1(1)$ & $.15 E-03$ & $9.15 E-03$ & $9.15 E-03$ & $9.15 E-0.3$ & 9.1 1 E -03 & $9.15 E=03$ \\
\hline L12S(1) & $! .97 E-16$ & $3.97 E-<16$ & $3.97 E-06$ & $3.97 E-06$ & $3.96 E-06$ & $3.96 \mathrm{E}-06<$ \\
\hline $1120(1)$ & $.18 E-06$ & $1.10 E-0 t$ & $1.18 E-06$ & $1.10 E-06$ & 1. 18E-06 & $1.18 E-06$ \\
\hline L12504 (1) & i. $3 E E-14$ & 5. 15E-14 & $6.14 E-14$ & 5. 14E-14 & $5.14 E-14$ & E. $13 E-14=$ \\
\hline$x 2 \cos (1)$ & $.44 E-02$ & $7.44 E-02$ & $.44 E-02$ & $7.44 E-02$ & $7.44 E-02$ & $7.44 E-02$ \\
\hline $\mathrm{KOH}(1)$ & $.86 E-04$ & -14 & 5. $86 E-04$ & $5.86 E-04$ & $5.86 E-04$ & $5.86 E-04$ \\
\hline$\times 251$ & $.44 E-017$ & $=-07$ & $1.44 E-07$ & $1.44 E-07$ & & $1.44 E-07 \%$ \\
\hline$\times 2011$ & $E-15$ & $1.39 E-15$ & $39 E-1 E$ & $E-1=$ & 10 & $1.39 E-15$ \\
\hline$\times 2504$ & $2 E-11$ & $2 E-11$ & $1.72 E-11$ & $2 E-11$ & $1.72 E-11$ & $1.72 E-11<$ \\
\hline Nicos (2) & $.165-09$ & $6 E \cdot 69$ & $2.16 E-09$ & $2.16 E-09$ & $2.16 E-09$ & $2.16 E-09$ \\
\hline$K_{2}(O H) 2(s)$ & . 3NE-CB & $-\infty$ & $-\infty B$ & $D E-O B$ & 08 & $3.305-O B$ \\
\hline$N_{1} S(1)$ & 4. $4 \pi-15$ & $4,43 E-05$ & 4. $43 E-05$ & 4. 43E-0 & 4. $12 E-05$ & $4.42 E-05$ \\
\hline$N_{2} O(1)$ & E. 1 $\theta E-\alpha^{\infty}$ & 5. $18 E-O 5$ & $5.18 E-\infty$ & $5.18 E-05$ & $5.18 F-05$ & $5.18 E-05$ \\
\hline N1504!(8) & 9. (AHE-24 & $9.04 E-24$ & $9.04 E-24$ & $9.03 E-24$ & $9.02 E-24$ & $9.02 E-24$ \\
\hline $\operatorname{PoCn} 3\langle 5\rangle$ & U. (X,E) + (1) & $1.00 E-69$ & 5. $41 E-09$ & $1.08 E-08$ & $2.16 E-08$ & $2.7715-094-$ \\
\hline$P t(D+H) 2(s)$ & $0.0,0 E+\infty)$ & 1.90E-12 & $9.51 E-12$ & $1.90 E-11$ & 3. B.E-11 & $4.07 E-18<$ \\
\hline & $0 . \operatorname{CNE} E+\infty)$ & D. BSE - Ob & 3. $44 E-O S$ & 6. BBE - OE & 1. 37E-04 & $1.76 E-04 \infty$ \\
\hline$P D O(1)$ & $0 .\left(N_{S} E+00\right.$ & $1.11 E-16$ & 5. $54 E-\infty 6$ & $1.11 E-05$ & $2.22 E-05$ & 2. Q4E- \\
\hline $70504(s)$ & $0.015 E+00$ & $3.42 E-23$ & $1.71 E-22$ & $3.421 \leq-22$ & 6. $925-22$ & $8.72 \mathrm{E}-22.2$ \\
\hline
\end{tabular}

C. EFFECTS ON IONIC COMPOSITION OF THE MEIT

\begin{tabular}{|c|c|c|c|c|c|c|}
\hline $\mathrm{Ll}+$ & b. $2(E-01$ & $6.20 E-01$ & b. $205=01$ & $6.200-01$ & 6. 20E-01 & $6.20 E-01$ \\
\hline$k+$ & 3. EJE-01 & 3. 8DE- -1 & 3. BOE-01 & 3. BOE-01 & 3. $00 E-01$ & $3.80 E-01$ \\
\hline $\mathrm{Ni}+2$ & $4.415=09$ & $4.41 E-09$ & 4. A1E-09 & $4.41 E-00$ & $4.41 E-09$ & $4.41 E-09$ \\
\hline $\mathrm{PO}+2$ & $0.1 \times J E+000$ & $2.02 E-19$ & $1.01 E-00$ & 2. $12, E-08$ & $4.04 E-08$ & $5.16 E-084$ \\
\hline $\mathrm{CO}=$ & $9.08 E-01$ & 9. $B B E-01$ & $9.03 E-01$ & 9. $88 E-01$ & 9. $A B E-01$ & $9.8 B E-01$ \\
\hline at & $1.190-02$ & $1.18 E-02$ & $1.1 \mathrm{EE}-02$ & 1. $18 E-02$ & $2.885-02$ & 1. $1 \mathrm{EE}-\mathrm{OL}$ \\
\hline Sw & 4. $4 \mathrm{Jt}$ & $9.45 E-16$ & $4.45 E-06$ & 4. $45 E-06$ & $4.44 E=06$ & $4.44 E-0.64$ \\
\hline 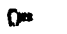 & $7.1 \pi \mathrm{E}-0 \mathrm{~B}$ & 7. $17 E-O A$ & $7.17 \mathrm{E}-0 \mathrm{~B}$ & 7. $17 E-00$ & $7.17 E-08$ & $7.17 E-O B$ \\
\hline $804=$ & $1.41 E-11$ & $1.41 E-11$ & $1.11 E-11$ & $1.41 E-11$ & $1.41 E-11$ & $1.41 E-11<$ \\
\hline
\end{tabular}

EPECIES PLESENT AS PLRE CONDENSED PNASES:

$\begin{array}{lllllll}\text { Po(i) } & \text { no } & \text { no } & \text { no } & \text { no } & \text { no } & \text { yes }- \\ \text { NI(er) } & \text { yos } & \text { yos } & \text { yos } & \text { yes } & \text { yes } & \text { yes }\end{array}$


TABLE III• 5

A. GAS SPECIES PARTIAL PRESSURES (ATM)

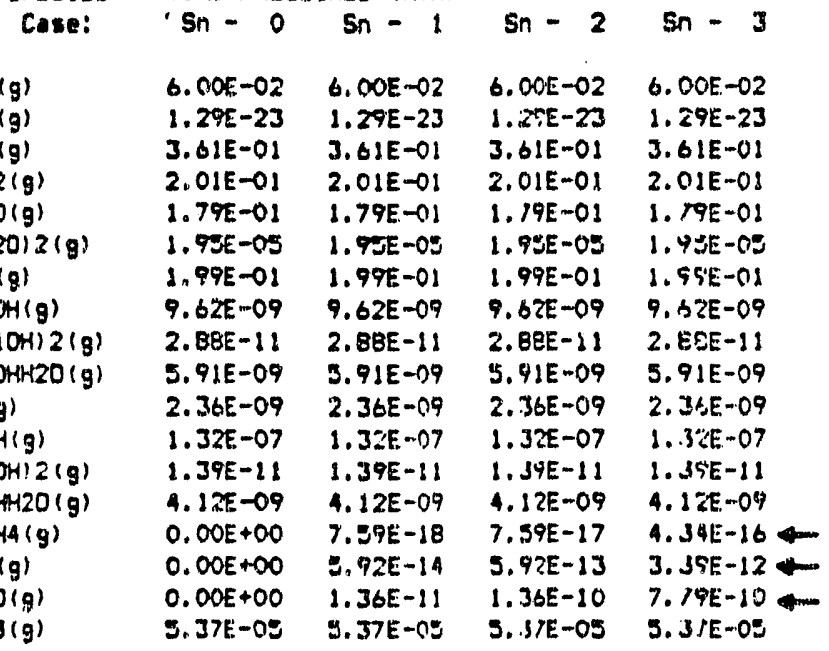

B. EPFECTS OF TIN TRACE SPECIES ON ACTIVITIES IN THE MEL,T

\begin{tabular}{|c|c|c|c|c|}
\hline $12603(1)$ & $2.37 E-01$ & $2.37 E-01$ & 2. $3 / \mathrm{E}-01$ & 2. 37E-01 \\
\hline LiOH(1) & 9. $15 E-03$ & $9.15 E-03$ & 9. $15 E-03$ & $9.15 E-03$ \\
\hline Li20(1) & $1.18 E-06$ & $1.18 E-06$ & 1. $1 B E-06$ & $1.18 E-06$ \\
\hline $\operatorname{cocos}(1)$ & $7.445-02$ & $7.44 E-102$ & $7.11 E-02$ & $7.1 .1 E-02$ \\
\hline $\mathrm{KOH}(1)$ & $5.86 E-04$ & $5.86 E-04$ & $5.86 E-0.4$ & 5. RLE-C4 \\
\hline$k=0(1)$ & $1.39 E-15$ & $1.391-15$ & $1.39 E-15$ & $1.35 E-15$ \\
\hline $\mathrm{NiCO} 3(1)$ & $2.16 E-09$ & 2. $16 E-09$ & $2.16 E-09$ & $2.16 E-09$ \\
\hline $\mathrm{Nj}(\mathrm{OH}) \geqslant(5)$ & 3. JOE-DB & 3. $30 \mathrm{E}-\mathrm{OE}$ & $3.30 E-08$ & 3. $20 E-08$ \\
\hline $\mathrm{NiO}(1)$ & $5.18 E-05$ & $5.18 E \cdot 05$ & $5.18 E-05$ & 5. $1 \mathrm{BE}-05$ \\
\hline $\sin \cos (s)$ & $0.00 E+00$ & $1.06 E-09$ & $1.06 E-09$ & 6. $O E E-O B$ \\
\hline $\operatorname{Sn}(O H) 2(s)$ & $0.00 E+00$ & $2.08 E-08$ & 2. $08 E-07$ & $1.19 E-06$ \\
\hline $\sin 0(1)$ & $0.00 E+00$ & $1.99 E-03$ & 1. 49E-02 & 0. $\triangle 3 \mathrm{JE}-02$ \\
\hline $\operatorname{sn}(\cos ) 2(5)$ & $0.00 E+00$ & $2.84 E-1 J$ & 2. BAE-12 & $1 .+32 E-11$ \\
\hline $\operatorname{Sn}(\mathrm{OH}) 4(\mathrm{~s})$ & $0,00 E+00$ & $2.18 E-13$ & $2.18 E-12$ & $1.7 .5 E-11$ \\
\hline $5 n 02(1)$ & $0.00 E+00$ & $1.17 E-04$ & $1.17 E-03$ & $6.72 E-03$ \\
\hline
\end{tabular}

C. EFFECT OF TIN ON IONIC COMPOSITION OF TRE MELT

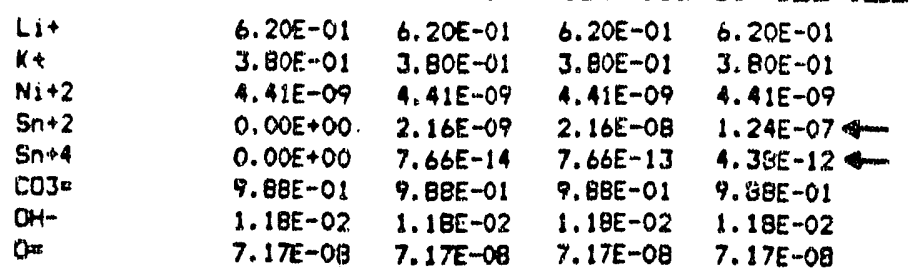

SFECIES PAESEIT AS PURE CONDENSED PHASES:

$\begin{array}{lllll}\sin (1) & \text { no } & \text { no } & \text { no } & \text { yes } \\ \text { Aid (cr) } & \text { yes } & \text { yes } & \text { yes } & \text { yes }\end{array}$


TABLF III 6

A. GAS SPECIES PARTIAL PRESSURES (ATM)

\begin{tabular}{|c|c|c|c|c|}
\hline Case: & $\operatorname{sn} / \mathrm{Ni}-\mathrm{O}$ & $\mathrm{Sn} / \mathrm{Ni}_{\mathrm{i}}-\mathrm{l}$ & $\sin / N_{2}-2$ & $\mathrm{Sn} / \mathrm{H} \mathrm{H}_{2}-3$ \\
\hline (g) & $6.00 E-02$ & $6.00 E-02$ & $6.00 E-02$ & $6.00 E-02$ \\
\hline (g) & $1.29 \mathrm{E}-2 \mathrm{~J}$ & $1.29 E-23$ & 1. $24 E-23$ & $1.29 E-2.3$ \\
\hline (g) & 3.6IE-01 & $3.61 E-01$ & $3.61 E-01$ & $3.61 E-01$ \\
\hline $2(g)$ & $2.01 E-01$ & 2. O1E-01 & $2.01 E-01$ & 2.01E-01 \\
\hline$O(g)$ & $1.79 E-01$ & $1.79 E-01$ & $1.79 E-01$ & $1.74 E-01$ \\
\hline $12012(g)$ & $1.95 E-05$ & $1.95 E-05$ & 1.95E-05 & $1.43 E-05$ \\
\hline (g) & $1.99 E-01$ & $1.99 E-01$ & $1.99 E-0 !$ & $1.975-01$ \\
\hline IOHIy: & $9.62 E-09$ & $9.62 E-09$ & $9.62 E-09$ & $9.67 E-09$ \\
\hline$(\mathrm{OH}) 2(\mathrm{y})$ & $2.8 B E-11$ & $2.8 B E-11$ & 2. B8E-11 & 2. $83 E-11$ \\
\hline $10+1+20(\mathrm{~g})$ & $5.91 E-09$ & $5.91 E-09$ & $5.91 E-09$ & $5.91 \mathrm{E}-09$ \\
\hline (g) & $2.365-09$ & $2.36 E-09$ & $2.36 E-09$ & $2.36 E-09$ \\
\hline$H(g)$ & 1. $32 \mathrm{E}-0.07$ & 1. $32 E-07$ & $1.32 \mathrm{E}-07$ & $1.32 E-07$ \\
\hline DHIZ(g) & $1.39 E-11$ & $1.39 E-11$ & $1.39 E-11$ & $1.39 E-11$ \\
\hline $\mathrm{HH}=\mathrm{H}$ (g) & 1. $12 E-09$ & A. $12 E-09$ & $4.12 E-09$ & $4.17 E-09$ \\
\hline & $0.00 E+\infty$ & $7.46 \mathrm{E}-21$ & $2.24 E-20$ & $1.91 E-18<-$ \\
\hline & $0.00 E+00$ & $5.82 E-17$ & $1.79 E-16$ & $1.47 E-14 \leftarrow$ \\
\hline (g) & $0.00 E+\infty$ & $1.34 E-14$ & 4. $11 E-14$ & $3.43 E-12 \propto-$ \\
\hline & 3. $37 \varepsilon-0.5$ & 5. $3 T E-05$ & $5.37 E-05$ & 5.37 E-05 \\
\hline
\end{tabular}

R. EFPECTS OF TIN TRACE SFECIES ON ACTIVITIES IN MULT

\begin{tabular}{|c|c|c|c|c|}
\hline Li2cos 111 & 2.37E-01 & 2. 37E-01 & 2. $37 \mathrm{E}-01$ & $2.37 E-01$ \\
\hline $\mathrm{LiOH}(1)$ & $9.15 E-03$ & $9.15 E-03$ & $9.15 E-03$ & $9.15 E-03$ \\
\hline $4120(1)$ & 1. $18 E-06$ & $1.16 E-06$ & 1. $1 \mathrm{BE}-06$ & 1. $18 E-06$ \\
\hline$k 2 \cos (1)$ & $7.44 E-02$ & $7.44 E-02$ & 7. $41 E-02$ & $7.11 E-02$ \\
\hline $\mathrm{KOH}(1)$ & J. B6E -04 & $5.86 E-04$ & $5.86 E-04$ & 5. BLE -OA \\
\hline$\times 20(1)$ & $1.39 E-15$ & $1.39 E-15$ & $1.39 E-15$ & $1.35 E-15$ \\
\hline $\mathrm{NiCOJ}(3)$ & $2.16 E-09$ & $2.16 E-09$ & $2.16 E-09$ & 2. $16 E-09$ \\
\hline $\mathrm{Ni}(\mathrm{OH}) 2(5)$ & $3.30 E-O B$ & 3. $30 E-O B$ & 3. $30 E-08$ & $3.30 E-00$ \\
\hline NiD(1) & $5.18 E-05$ & $5.18 E-05$ & $5.18 E-05$ & $5.18 E-05$ \\
\hline $\sin \mathrm{CO}_{3}(\mathrm{~s})$ & $0.00 E+00$ & $1.04 E-12$ & 3. $19 E-12$ & $2.66 E-10<$ \\
\hline $5 n(D+1) 2(5)$ & $0.00 E+00$ & $2.05 E-11$ & $6.29 E-11$ & $5.25 E-094-$ \\
\hline $\operatorname{SnO}(1)$ & $0.00 E+00$ & $1.46 E-06$ & 4. $50 E-06$ & 3.7 bE -04 \\
\hline $5 n(\cos ) 2(s)$ & $0.001 E+00$ & $2.79 E-16$ & Q. $57 E-16$ & $7.15 E-14 \&$ \\
\hline $5 n(O K) A(5)$ & $0.00 E+00$ & $2.15 E-16$ & $6.50 E-16$ & $5.50 E-144$ \\
\hline $5 n D 2(1)$ & $0.00 E+00$ & 1. $25:-07$ & 3 SSE-07 & $2.96 E-05$ \\
\hline
\end{tabular}

C. EFFECT OF TIN ON IONIC COMPOSITION OF THE MELT

\begin{tabular}{|c|c|c|c|c|}
\hline LIt & $6.20 E-01$ & $6.20 E-01$ & $0.20 E-08$ & $0.20 E-01$ \\
\hline$k+$ & $3.80 E-01$ & 3. $B O E-01$ & $3.80 E-01$ & J. EOE-OI \\
\hline $\mathrm{Ni}+2$ & $4.41 E-09$ & A.AIE-O9 & $4.41 E-09$ & $4.41 E-09$ \\
\hline $5 n+2$ & $0.00 E+00$ & 2. $12 E-12$ & $6.52 E-12$ & $5.14 E-104-$ \\
\hline $5 n+4$ & $0.00 E+\infty$ & $7.52 E-17$ & $2.31 E-16$ & $1.93 E-144-$ \\
\hline $\cos =$ & $9.88 E-01$ & $9.88 E .01$ & 9. BBE-01 & 9. B8E-01 \\
\hline $\mathrm{OH}-$ & 1. $1 \mathrm{BE}-02$ & 1. $18 \mathrm{BE}-02$ & 1. $18 E-02$ & $1.18 E-02$ \\
\hline $0=$ & $7.1 \pi E-0 B$ & $7.17 E-08$ & $7.17 E-08$ & $7.17 E-O B$ \\
\hline
\end{tabular}

SPECIES PRESENT AS PURE CONDENSED PHASES:

$\begin{array}{lllll}N 13 \operatorname{Sn}(s) & \text { no } & \text { yes } & \text { no } & \text { no } \\ N 13 \operatorname{Sn} 2(s) & \text { no } & \text { no } & \text { yes } & \text { no } \\ \text { NiJ } \operatorname{Sn} 4(s) & \text { no } & \text { no } & \text { no } & \text { yes } \\ N i(C r) & \text { yes } & \text { yes } & \text { yes } & \text { yes }\end{array}$


TABLE III०7

A. GaS SPECIES PAFTIAL PRESSURES (ATH)

\begin{tabular}{|c|c|c|c|c|c|c|}
\hline 258: & $|C| / 5 n-0$ & $\mathrm{HCl} / \mathrm{Sn}-1$ & $\mathrm{HCl} / \mathrm{sn-2}$ & $H C \perp / 8 n-3$ & $1 \times 1 / 5 n-4$ & ACl $1 / \sin -5$ \\
\hline $2(\theta)$ & $6.00 E-02$ & $6.005-02$ & $6.00 E-02$ & $6.005-02$ & $3.9 B E-02$ & $3.78=02$ \\
\hline $12(g)$ & $1.29 E-23$ & $1.2 \%-23$ & $1.29 E-23$ & $1.305-23$ & $1.32 E-23$ & $1.324=-23$ \\
\hline$(g)$ & $3.61 E-01$ & 3. $61 E-01$ & $3.61 E-01$ & 3. $61 E=01$ & $3.60 E-01$ & $3.60 E-01$ \\
\hline $2(y)$ & $0.00 E+00$ & $1,2 \pi-29$ & 1. $.25 E-27$ & $1.265=-25$ & $1.27 E-23$ & $1.27 \mathrm{E}-23<$ \\
\hline $2(g)$ & $.0|E-0|$ & $2.01 E-01$ & $2.01 E-01$ & $2.02 E-01$ & $2.02 E-01$ & $2.02 E-01$ \\
\hline$O(g)$ & $1.79 E-01$ & $1.79 E-01$ & $1.79 E-01$ & $1.19 E-O 1$ & 1. DOE-01 & 1. BOE -01 \\
\hline $2012(g)$ & 1, QSE-OS & $1.95 E,-05$ & $1.95 E-05$ & $1.96 E-65$ & 1. 9EE-05 & $1.905-05$ \\
\hline$(g)$ & $1.99 E-01$ & $1.99 E-01$ & $1.99 E-01$ & $1.99 E-01$ & $1.98 E-01$ & $1.98 E-01$ \\
\hline & 9.625 & $9.62 E-19$ & $9.62 E-09$ & 9.5SE-09 & $9.07 E-09$ & $9.07 E-09$ \\
\hline 1 CHIZ(g) & 2. BBE-11 & 2. $B B E-11$ & 2. $87 E-i 1$ & 2.835 & 2. 5se-11 & 2. $55 E-11$ \\
\hline OHA20 (g) & $5.71 E-09$ & $3.91 E-09$ & $-\infty 9$ & $5.67 E-09$ & 3.608 & $5.606-09$ \\
\hline$C)(0)$ & $0.00 E+\infty 0$ & $1.00 E$ & $=-\infty$ & 1.04E-08 & 9.926 .08 & $.92 E-0 B$ \\
\hline & $2.36 E$ & 2.3 & -09 & 2.10 & $1.19 E-09$ & $1.1 \% E-09$ \\
\hline$H(g)$ & 1.32 & & & 1.2 & $6.67 E-08$ & $6.67 E-08$ \\
\hline$(D+1) 2(g)$ & $1.39 E-11$ & $9 E-11$ & & & $3.56 E-12$ & $3.56 E-13$ \\
\hline$+20(g)$ & $4.12 \pm-$ & 4.12E-OO & 9.09 & $3,81 E-09$ & 2. $10 E-09$ & $2.10 E-09$ \\
\hline & $0.00 E+\infty 0$ & $2.30 \mathrm{E}-(\mathrm{JB}$ & 2.28 & $2.83 E=.06$ & 1. $27 E-05$ & $1.17 E-050$ \\
\hline (g) & $0.00 E+\infty$ & $6.09 E-20$ & 6.10 & $6.11 E-1 B$ & $6.15 E-17$ & $6.15 E-17 \leftarrow$ \\
\hline $2(g)$ & $0.00 E+\infty$ & $2.23 E-23$ & $2.24 t$ & $2.25 E-19$ & $2.28 E-17$ & $2.28 E-17<$ \\
\hline $12(g)$ & $0.00 E+00$ & $1.70 t-17$ & 1. 1 CE -15 & $1.71 E-13$ & $9.44 E-12$ & $1.73 E-11<m$ \\
\hline $14(9)$ & $0.00 \varepsilon+00$ & $6.68 E-3 B$ & $6.72 E$ & $6.7 \mathrm{EE}-30$ & $3.79 E-26$ & $0.96 E-26 \leftarrow$ \\
\hline sigi & $7.59 E-17$ & 4. $34 E-16$ & 4.34 & $4.34 E-16$ & $2.35 E-16$ & $4.32 E-16$ \\
\hline & $5.92 E-$ & 3. 3PE-12 & 3. 39E. & 3.39 & 1.85E-12 & 3.391 .124 \\
\hline & $1.36 E-10$ & $7.79 E-10$ & $7.79 E-$ & & $1.28 E-10$ & $7.8 \Delta E-10 \leftarrow$ \\
\hline & $3.37 E-05$ & \$. 37E-0\% & 5. JIE-OS & $3.57 E-03$ & $5.34 E-05$ & 5. 34E-0E \\
\hline | & $0.00 E+\infty$ & $1.01 E-19$ & 1.01E-0B & $1.01 E-07$ & $1.02 E=06$ & $1.02 \mathrm{E}-064$ \\
\hline
\end{tabular}

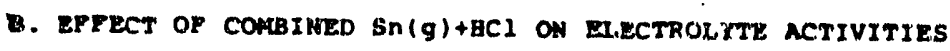

\begin{tabular}{|c|c|c|c|c|c|c|}
\hline $\begin{array}{l}\text { LizCO3(1) } \\
\text { LiDH(1) } \\
(1 C: 11)\end{array}$ & $\begin{array}{l}2.37 E-01 \\
9.15 E-03 \\
0.00 E+00\end{array}$ & $\begin{array}{l}\text { 2. } 37 E-01 \\
9.15 E-03\end{array}$ & $\begin{array}{l}2.31 E-01 \\
9.1 \pm E-03\end{array}$ & $\begin{array}{l}2.2 A E-01 \\
9.03 E-03\end{array}$ & $\begin{array}{l}\text { 2. } 11 E-01 \\
8.62 E-03\end{array}$ & $\begin{array}{l}\text { 2. 11E-01 } \\
8.62 E-03\end{array}$ \\
\hline (nEC:1]) & $0.00 E+100$ & $3.07 E-06$ & 3.07E-05 & 3.0.5E-04 & $2.90 E .-03$ & $2.90 E-03 \&$ \\
\hline $4120(1)$ & $2.18 E-06$ & $1.18 E-06$ & 1.17E-06 & $1.10, E-06$ & $1.04 E-06$ & $1.04 E-06$ \\
\hline$k=\cos (1)$ & $7.44 E-02$ & $7.43 E-02$ & $7.32 \mathrm{E}-02$ & $6.36 E-02$ & $1.91 E-02$ & $1.91 E-02$ \\
\hline$x D+1(1)$ & 5. $8 t_{L}-04$ & 5. $8 \in E-04$ & S. BIE-OA & 5. 42E -04 & $2.97 E-04$ & $2.97 E-04$ \\
\hline$k C l(1)$ & $0.00 E+\infty$ & $9.64 E-04$ & $9.525-03$ & $8.94 E-02$ & 4. $90 E-01$ & $4.90 E-01<$ \\
\hline$x=0(1)$ & $1.39 E-15$ & $1.39 E-15$ & 1. $.37 E-15$ & $1.19 E-15$ & $3.55 E-16$ & $3.55 E-16$ \\
\hline $\operatorname{NicD3}(1)$ & $2.16 E-09$ & $2.16 E-09$ & $2.16 E-09$ & $2.17 E-09$ & $2.19 E-09$ & $2,19 E-09$ \\
\hline $\mathrm{N}_{1}(\mathrm{OH}) 2(\mathrm{~s})$ & $3.30 E-08$ & 3. $30 E-08$ & 3. 30E-08 & 3. $30 E-O B$ & $3.35 E-00$ & $3.35 E-00$ \\
\hline $\mathrm{N} \perp C 12$ (1) & $.00 E+00$ & $2.04 E-21$ & $2.04 E-19$ & $2.05 E-17$ & $2.08 E-15$ & $2.08 E-15<$ \\
\hline NIOUI) & 5. $18 E-05$ & $5.185-05$ & $3.18 \mathrm{E}-0 \mathrm{~S}$ & 5. 18E-0S & 5. 22E-05 & $5.22 \mathrm{E}-05$ \\
\hline $\operatorname{snc03}(\mathrm{s})$ & $1.06 E-08$ & $6.05 E-08$ & 6. OSE -08 & $6.00 E-00$ & $3.34 E-09$ & $6.13 E-0.8<$ \\
\hline $\mathrm{Sn}(\mathrm{OH}) 2(\mathrm{~s})$ & 2.08E-07 & $1.19 E-06$ & $1.19 E-06$ & $1.19 E-06$ & $6.99 E-07$ & $1.21 E-060$ \\
\hline $\operatorname{snc} 12(1)$ & $0.00 E+00$ & $1.74 E-17$ & $1.74 E-15$ & $1.75 E-13$ & $9.67 E-12$ & $1.77 E-11 \leftarrow$ \\
\hline $5 n 0111$ & $1.49 E-02$ & 8. 53E-02 & 8.5SE-02 & B. 5 iE -122 & 4. 69E -02 & $8.61 E-02$ \\
\hline $5 n([03) 2(s)$ & $2.84 E-12$ & $1.62 E-11$ & $\mid .6 \hat{a} E-11$ & $1.63 E-11$ & $9.10 E-12$ & $1.67 E-11<$ \\
\hline Sn $(O H) 4(s)$ & $2.18 E-12$ & $1.25 E-11$ & $1.25 E-11$ & $1.25 E \cdots 11$ & $7.01 E-12$ & $1.29 E-11 \leftarrow$ \\
\hline $\sin [11(1)$ & $0.00 E+00$ & $0.00 E+00$ & Q. $18 E-36$ & B. $24 E-32$ & $4.62 E-2 B$ & $8.47 E-28 \leftarrow$ \\
\hline $5 n 02(1)$ & $1.17 E-03$ & $0.725-03$ & $6.725 . \cdots 03$ & $6.73 E=0.3$ & $3.73 E-03$ & $0.84 E-03 \leftarrow$ \\
\hline
\end{tabular}

c. EFFECT ON IONIC COAPOSITION OP THE MEeT

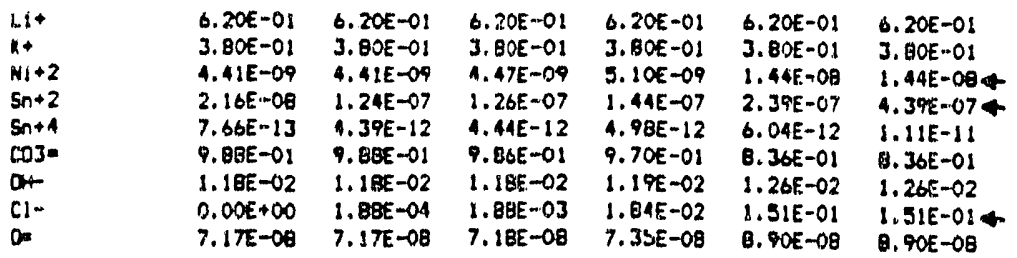

SPECIES PRESENT AS PUAE CONUENSED PHASES:

$\begin{array}{lllllll}\operatorname{sn}(1) & \text { no } & \text { yes } & \text { yes } & \text { yes } & \text { no } & \text { yes } \\ \text { WI (er) } & \text { yes } & \text { yes } & \text { yes } & \text { yes } & \text { yes } & \text { yes }\end{array}$


TABLE III• 8

A. gas sPECIES PAATIAL PREsSUREs (ATA)

Case: HZS/Sn-0 K2S/Sn-1

\begin{tabular}{|c|c|c|c|}
\hline$N=($ b) & $6.00 E-02$ & $6.00 E-02$ & $0.005-02$ \\
\hline $02(g)$ & $1.29 E-23$ & $1.29 E-23$ & $1.29 E-23$ \\
\hline$M Q(g)$ & $3.61 E-01$ & $3.61 E-01$ & $3.61 E=01$ \\
\hline $52(g)$ & $0,000+\infty)$ & $1.99 E-17$ & $7.47 E-17$ \\
\hline $\mathrm{CO} 2(\mathrm{~g})$ & $2.01 E-01$ & $2.01 E-01$ & $2.01 E-01$ \\
\hline $\mathrm{H} 2 \mathrm{O}(\mathrm{g})$ & $1.79 E-01$ & $1.79 E-01$ & $1,7 \% E-01$ \\
\hline$(\mathrm{H} 2 \mathrm{O}) 2(\mathrm{~g})$ & 1.95E-05 & $8.95 E-0 \%$ & $1.955-\cos$ \\
\hline$C 0(y)$ & $1.99 E-01$ & $1.99 E-01$ & $1.99 E-01$ \\
\hline $\operatorname{LIOH}(g)$ & 9. $12 E-09$ & $9.62 E-09$ & $9.62 E-09$ \\
\hline$(L, Q H) \geq(g)$ & 2. $8 B E-11$ & 2. BBE-11 & $2.8 B E-11$ \\
\hline $110+N 20(g)$ & $=.91 E-09$ & $5.91 E \multimap 09$ & 5. $91 E-\infty 9$ \\
\hline$F(g)$ & $2.36 E-09$ & $2.36 E-09$ & 2. $36 E-09$ \\
\hline $\operatorname{KOH}(g)$ & $1.321-07$ & 1. J2E-07 & $1.32 E-07$ \\
\hline$(K D H) 2(g)$ & 1. S4E-11 & $1.39 E-11$ & $1.39 E-11$ \\
\hline KOHK=D (g) & $4.12 E-09$ & 4. $12 E-09$ & $4.12 E-09$ \\
\hline $\cos (g)$ & $0.006+\infty 0$ & B.62E-09 & $1.876-08$ \\
\hline $\operatorname{Sin} H 4(g)$ & 9. $34 E-16$ & $7.10 E-17$ & 3. 1LE-17 \\
\hline $\operatorname{sn}(g)$ & 3. $39 E-12$ & 5. $34 E-1]$ & $2.10 E-13$ \\
\hline $\sin (g)$ & $0.00 E++00$ & $9.065-09$ & $9.54 E-09$ \\
\hline $\operatorname{sno}(9)$ & $7.74 E-10$ & $1.27 E-10$ & $6.20 E-11$ \\
\hline$N(3)$ & 5. 37E-05 & $5.37 E-05$ & 5. J7E- \\
\hline K25 (g) & $0.00 E+00$ & $1.91 E-07$ & $1.06 E-06$ \\
\hline
\end{tabular}

$165 / 5 n-3 \quad 125 / 5 n-4 \quad H 25 / 5 n-5 \quad H 25 / 5 n-6$

$\begin{array}{llll}6.00 E-02 & 6.00 E-02 & 6.00 E-02 & 6.00 E-0 ?\end{array}$

$\begin{array}{llll}1.29 E-23 & 1.29 E-23 & 1.29 E-23 & 1.29 E-23\end{array}$

3.61E-01 3.61E-01 3.61E-01 3.61E-01

1.01E-15 $1.72 E-17 \quad 7.01 E-17$ 1.72E-154

2.01E-01 2.01E-01 3.01E-01 2.01E-01

$1.79 E-01$ 1.79E-0! $1.79 E-0 !$ 1.79E-D1

1. VEE-OS $1.95 E-05$ 1.4SE-CS $1.95 E-05$

$1.99 E-01$ 1.99E-01 1.99E-01 1.79E-01

$9.62 E-09$ 9.62E-09 9.62E-09 9.62E-09

2.87E-11 2.B8E-11 2. BBE-11 2.87E-11

$5.91 E-09 \quad 3.91 E-C Q \quad 5.91 E-09 \quad 2.01 E-09$

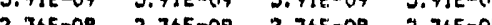

2.36E-09 2.36E-09 2.36E-09 2.36E-09

1.JSE-11 1.39E-1: $1.39 E-11$ 1.39E-11

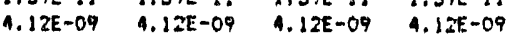

8.75E-09 B.96E-09 1.81E-08 $8.96 E-08$

$7.64 E-18 \quad 4.34 E \cdot 16 \quad 4.34 E-16 \quad 4.34 E-16$

5.96E-14 3.39E-12 3.39E-12 3.39E-12 4

9.90E-09 $\$ .76 E-08$ 1.16E-07 $5.76 E-074$

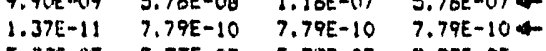

5.JTE-OE 3.37E-0J $5.37 E-05$ J.37E-0\%

K25 (g)

$4.99 E-06$

S. $11 E-07$

$1.03 E \cdot 06$

B. EFFECT OF COMBINED $S n(g)+$ B25 ON RLECTROLYTE ACTIVITIES

\begin{tabular}{|c|c|c|c|c|c|c|c|}
\hline $\begin{array}{l}\mathrm{L} 12 C 03(1) \\
\mathrm{LIOH}(1)\end{array}$ & $\begin{array}{l}2.37 E-01 \\
9.15 E-03\end{array}$ & $\begin{array}{l}2.37 E-01 \\
9.15 E-03\end{array}$ & $\begin{array}{l}2.37 E-01 \\
9.25 E-03\end{array}$ & $\begin{array}{l}2.37 E-01 \\
9.15 E-03\end{array}$ & $\begin{array}{l}2.37 E-01 \\
9.15 E-03\end{array}$ & $\begin{array}{l}2.37 E-01 \\
9.15 E-03\end{array}$ & $\begin{array}{l}2.37 E-01 \\
9.15 E-03\end{array}$ \\
\hline Li25111 & $.00 E+00$ & $1.82 \mathrm{E}-06$ & $3.44 E-06$ & 1. $25 E-05$ & 1. $89 E-06$ & $3.82 E-06$ & 1. B9E-05 $\leftarrow$ \\
\hline Li20(1) & $.10 E-O b$ & 1. $19 E .06$ & $1.18 E-06$ & 1. $18 E-06$ & 1. $18 E-06$ & $1.18 E-06$ & 1.16E-06 \\
\hline L(2504 (1) & $0.00 E+\infty 0$ & $2.36 E-19$ & $5.11 E-14$ & 2. 34E-13 & $2.45 E-14$ & $4.95 E-14$ & $2.45 E-13$ \\
\hline$\times 2 \cos (1)$ & $7.44 E-02$ & $7.44 E-02$ & $7.44 E-02$ & $7,44 E-02$ & $7.44 E-02$ & $7,44 E-02$ & $7.44 E-02$ \\
\hline $\mathrm{KDH}(1)$ & 3. $06 E-04$ & 5. $86 E-0.4$ & $5.865-04$ & $5.365-04$ & $5.86 E-04$ & $5.86 E-154$ & $5.86 E-01$ \\
\hline K25(1) & $.00 E+00$ & $6.61 E-08$ & $1.43 E-07$ & $6.71 E-07$ & D. B7E-OB & $1.39 E-07$ & $6.87 E-07 \leftarrow$ \\
\hline K.30:11 & $1.39 E-15$ & $1.39 E-15$ & $1.39 E-15$ & $1.39 E-15$ & $1.39 E-15$ & $1.39 E-15$ & 1.39E-15 \\
\hline$\times 250111)$ & $0.00 E+\infty$ & 7. $89 E-12$ & $1.71 E-11$ & 8.00E-11 & 8. $20 E-12$ & $1.65 E-11$ & $8.20 E-11$ \\
\hline$N_{1} \operatorname{Cos}(1)$ & $2.16 E-09$ & $2.16 E-09$ & $2,16 E-09$ & $2.16 E-09$ & 2. $16 E-09$ & $2.16 E-09$ & $2.16 E-09$ \\
\hline $\mathrm{Ni}(\mathrm{OH}) 2(\mathrm{~S})$ & $3.305-00$ & 3. $.0 E-08$ & 3. $30 E-08$ & $3.30 E-08$ & 3. 3OE $-O B$ & 3. 3DE-OB & 3. 3OE-OB \\
\hline N15(1) & $0.00 E+00$ & $203 E-05$ & 1. 10E-05 & $2.06 E-04$ & 2. $31 E-05$ & $4.26 E-05$ & $2.11 E-04 \&$ \\
\hline $\mathrm{N} / \mathrm{O}(1)$ & $5.18 E-05$ & $\therefore 18 E-05$ & 5. $18 E-05$ & 5. $18 E-05$ & $5.18 E-05$ & 5. $28 E-05$ & $5.10 E-05$ \\
\hline $\mathrm{N}, 504(\mathrm{~s})$ & $0.00 E+00$ & $1.15 E-24$ & $7 E-24$ & $21 E-23$ & $4.31 E-24$ & 6.69E-24 & $4.31 E-2.3$ \\
\hline $\sin \cos (5)$ & 6. 0SE -08 & $9.89 E-09$ & $4.81 E-09$ & $1.06 E-09$ & $6.05 E-08$ & $6.05 E-08$ & $6.05 E-08 \div$ \\
\hline $5 n(O H) 2(s)$ & $1.19 E-O 6$ & $1.95 E-07$ & $9.49 E \cdots 08$ & $2.10 E-0 B$ & $1.19 E-06$ & $1.19 E-06$ & $1.19 E-06 \propto$ \\
\hline $\sin 5(1)$ & $0.00 E+\infty$ & $2.97 E-05$ & 3. $12 E-05$ & $3.24 E-05$ & $1.89 E-01$ & $3.80 E-04$ & $1.89 E-03 \leftarrow$ \\
\hline $\operatorname{SnD}(1)$ & 8.53E-02 & 1. $40 E-02$ & $6.79 E-03$ & $1.505-0.3$ & B. 53F -02 & B. 5JE 02 & $8.53 E-02 \leftarrow$ \\
\hline $\sin 504(8)$ & $0.00 E+00$ & $2.56 E-16$ & $2.69 E-16$ & $2.79 E-16$ & $1.63 E-15$ & 3. $28 E-15$ & $1.63 E-14 \leftarrow$ \\
\hline $\operatorname{Sn}(\mathrm{CO}) 3(5)$ & $1.625-11$ & $2.666 \mathrm{E}-12$ & 1.29E-12 & 2. $3 b E-13$ & $1.62 E-11$ & $1.62 E-11$ & $1.62 \mathrm{E}-114$ \\
\hline $\operatorname{Sn}(O M) 4(5)$ & $1.25 E-11$ & $2.04 E \cdots 12$ & $9.95 E-13$ & $2.20 E-13$ & $1.25 E-11$ & $1.25 E-11$ & $1.25 E-11=$ \\
\hline $5 \operatorname{nn} 52(5)$ & $0.00 E+00$ & 1.87E-12 & $4.27 E-12$ & $2.06 E-11$ & $1.24 E-11$ & $5.03 E-11$ & $1.2 A E-09 \square$ \\
\hline $5 n 02(1)$ & 6. $72 E-03$ & $1.10 E-03$ & 5. $35 E-04$ & 1. $18 E-04$ & $6.72 E-03$ & $6.72 E-03$ & $6.72 E-03-0$ \\
\hline $5 n(50+12(5)$ & $0.00 E+\infty 0$ & $0.00 E+00$ & $0.00 E+\infty 0$ & $0.005+\infty$ & $0.00 E+\infty O$ & $0.00 E+00$ & $0.00 E+00$ \\
\hline
\end{tabular}

C. EFFECT ON IONIC COMPOSITION OF THE MELT

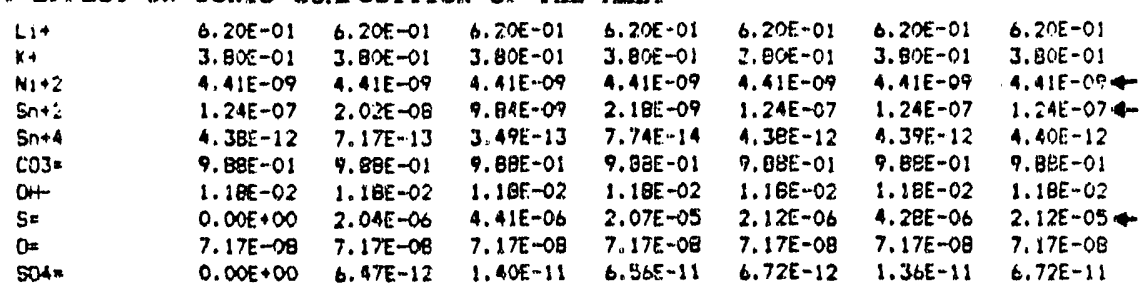

SFELIES PRESENT AS MUE CONDENSED MHASES:

$\begin{array}{llllllll}\sin (1) & \text { yes } & \text { no } & \text { no } & \text { no } & \text { yes } & \text { yes yes } \\ \text { N2 }(E T) & \text { yes } & \text { yes } & \text { yes } & \text { yes } & \text { yes } & \text { yes yes yes }\end{array}$


TABLE IV 1

A. GAS SEECIES FAFT! FA FRESSURES (ATM)

Case: in -0 in -1

$2 n-23 n-3 \quad 2 n-42 n-5$

\begin{tabular}{|c|c|c|c|c|c|c|}
\hline$N 2(g)$ & 6. पैJ)E- $(12$ & $6.00 E-02$ & 6. $00 E-02$ & $6.00 E-02$ & $6.00 E-02$ & $6.00 E-02$ \\
\hline $02(g)$ & 1. TPE-23 & $1.29 E-23$ & $1.29 E-23$ & $1.29 E-23$ & $1.29 E-23$ & $1.29 E-23$ \\
\hline$H_{2} 2(g)$ & $3.6 ! E-01$ & $3.61 E-01$ & 3.61E-01 & 3.61E-01 & $3.61 E-01$ & $3.61 E-01$ \\
\hline $\cos (g)$ & $2.0: E-01$ & $2.01 E-01$ & $2.01 E-01$ & $2.01 E-01$ & 2.01E-01 & $2.01 E-01$ \\
\hline $\mathrm{H} 2 \mathrm{O}(\mathrm{g})$ & $1.79 E-01$ & $1.79 E-01$ & $1.79 E-01$ & $1.79 E-01$ & $1.79 E-01$ & $1.79 E-01$ \\
\hline$(H 20) 2(g)$ & 1. 95E-0\% & $1.75 E-05$ & $1.9 \$ E-05$ & $1.95 E-03$ & $1.95 E-05$ & $1.9 \mathrm{EE}-0 \mathrm{5}$ \\
\hline $\cos (g)$ & $1.99 E-01$ & $1.99 E-01$ & $1.99 E-01$ & $1.99 E-01$ & $1.99 E-01$ & $1.99 E-01$ \\
\hline LJOII $(g)$ & $9.62 E-09$ & $9.62 E-09$ & $9.62 E-09$ & $9.62 E-09$ & $9.62 E-09$ & $9.62 E-09$ \\
\hline (LIOH) $2(\mathrm{~g})$ & $2.8 B E-11$ & 2. $88 E-11$ & 2. BQE-11 & 2. $8 B E-11$ & 2. $88 E-11$ & $2.88 E-11$ \\
\hline L. $10 H H 2 O$ (g) & $5.91 E-09$ & $9.91 E-09$ & $3.91 E-09$ & $5.91 E-09$ & $5.91 E-09$ & $5.91 E-09$ \\
\hline$k(g)$ & 2. $3 D E-09$ & $2.36 E-09$ & $2.36 E-09$ & $2.365-09$ & $2.36 E-09$ & $2.36 E-09$ \\
\hline $\mathrm{KOH}(g)$ & $1.32 E-07$ & $1.32 \mathrm{E}-07$ & $1.32 E-07$ & $1.32 E-07$ & $1.32 E-07$ & 1.32E-07 \\
\hline$(k 011) 2(g)$ & $1.3 P E-11$ & $1.39 E-11$ & $1.39 E-11$ & 1. 39E-11 & $1.39 E-11$ & $1.39 E-11$ \\
\hline KOHIIZO(g) & $4.12 E-07$ & $4.12 E-09$ & $4.12 E-09$ & $4.12 E-09$ & 4.12E-O? & $4.12 E-09$ \\
\hline $\ln (g)$ & 0. C.JEE $+\infty 0$ & $1.08 E-06$ & $4.99 E-06$ & $1.01 E-05$ & $1.31 E-05$ & $2.01 E-054$ \\
\hline $\mathrm{NH} 3(\mathrm{~g})$ & S. ZᄀE - & $3.37 E-0.5$ & 5.37E-05 & $5.37 E-05$ & $5.37 E-05$ & $5.37 E-05$ \\
\hline
\end{tabular}

B. RFFECT OF Zn ON ELECTROLXTE ACTIVITIES AS MOLECULAR SPECIES

\begin{tabular}{|c|c|c|c|c|c|c|}
\hline $\operatorname{Li2} \operatorname{Co3}(1)$ & $2.37 \mathrm{~T}-01$ & $2.37 E-01$ & $2.37 E-01$ & $2.37 E-01$ & $2.37 E-01$ & 2.37E-O1 \\
\hline Linti11) & $0.15 E-03$ & $9.15 E-03$ & $9.15 E-03$ & $9.15 E-03$ & $9.15 E-03$ & $9.15 E-03$ \\
\hline $\operatorname{Li20(1)}$ & $1.19 E-06$ & $1.18 E-06$ & $1.18 E-06$ & 1. $18 E-06$ & $1.18 E-06$ & $1.18 E-06$ \\
\hline$K 2 \cos (1)$ & $7.4 A E-02$ & $7.44 E-0.2$ & 7. $44 E-02$ & $7.44 E-O_{2}$ & $7.44 E-02$ & $7.44 E-02$ \\
\hline $\mathrm{KOH}(1)$ & 5. BGEE-04 & $5.86 E-104$ & 5. $86 E-04$ & $5.86 E-04$ & $5.86 E-04$ & $5.86 E-04$ \\
\hline$k 20(1)$ & $1.375-15$ & $1.39 E-15$ & i. $39 E-15$ & $1.39 E-15$ & 1. $39 E-15$ & $1.39 E-15$ \\
\hline $\mathrm{NiCO3}(1)$ & $2.16 E-019$ & $2.16 E-09$ & $2.16 E-09$ & $2.16 E-09$ & $2.16 E-09$ & $2.16 E-09$ \\
\hline $\mathrm{Ni}(\mathrm{OH}) 2(\mathrm{~s})$ & 7. $395-18$ & $3.30 E-09$ & $3.30 E-08$ & 3. $30 E-O E$ & 3. $30 E-O B$ & $3.30 E-08$ \\
\hline $\mathrm{NiO}(1)$ & $=.13 E-05$ & $3.18 E-05$ & $5.18 E-05$ & $5.10 E-05$ & $5.18 E-05$ & $5.18 E-0.5$ \\
\hline $2 r: \cos (5)$ & $0.6 \% J E+00$ & 8. $18 E-05$ & 4. $03 E-07$ & 8. $18 E-07$ & $1.22 E-06$ & $1.62 \mathrm{E}-06$ \\
\hline $2 n(04) \geq(5)$ & $\left.0.1 W_{L} E+10 j\right)$ & 1. $18 E-07$ & $5.79 E-07$ & 1.18E-0t & 1.75E-O6 & $2.33 E-06$ \\
\hline $2 r: 0(1)$ & $0.1 \% J E+100$ & $5.87 E-03$ & $2.89 E-02$ & 5. $87 E-02$ & $8.75 E-02$ & $1.16 E-01$ \\
\hline
\end{tabular}

C. EFFECTS ON IONIC COMPOSITION OF THE HEXT

\begin{tabular}{|c|c|c|c|c|c|c|}
\hline $\mathrm{LI+}$ & 6. $2 x \leq E-01$ & $6.20 E-01$ & $6.20 E-01$ & $6.20 E-01$ & $0.20 E-01$ & $6.20 E-01$ \\
\hline$k+$ & 3. B:E-(11 & 3. $80 E-01$ & 3. BOE -01 & 3. BOE-01 & 3.80E-01 & $3.80 E-01$ \\
\hline $\mathrm{Ni}+2$ & 4. $4: E-O P$ & $4.41 E-09$ & 4. $41 E-09$ & $4.41 E-09$ & $4.41 E-09$ & $4.41 E-09$ \\
\hline $2 n+2$ & $0.00, E+100$ & 1. $62 E-07$ & $7.99 E-07$ & $1.62 E-06$ & $2.42 E-06$ & $3.21 E-06<$ \\
\hline $\cos =$ & $9.89 E-(01)$ & $9.09 E-01$ & $9.88 E \sim 01$ & 9. BBE-O1 & 9. B8E-01 & $9.88 E-01$ \\
\hline OH- & $1.19 E-02$ & 1. $18 E-02$ & 1. $18 E-02$ & $1.18 E-02$ & 1.10E-02 & 1.19E-02 \\
\hline $0=$ & $7.17 E-118$ & $7.17 E-68$ & $7.17 E-08$ & $7.17 E-08$ & $7.18 E-08$ & $7.18 E-08$ \\
\hline
\end{tabular}

SPECIES PRESENT AS PLIRE COTDENSED PMASES:

Ni(cr) yes yes yes yes yes yes 
TABLE IV 2

A. gAS SFECIES PARTIRL PRESSURES (ATM)

\begin{tabular}{|c|c|c|c|c|c|c|}
\hline Case: & $2 n-0$ & $2 n-1$ & $2 n-$ & $2 n-$ & $\ln \cdots$ & 2n - \\
\hline N2 $(g)$ & 6. $1 K J E-02$ & $6.00 E-02$ & $6.00 E-02$ & $6.00 E-02$ & $6.00 E-02$ & $4.00 E-02$ \\
\hline $02(g)$ & 1. $20 E-23$ & $1.29 E-23$ & $1.29 E-23$ & $1.79 E-23$ & $1.29 E-23$ & $1.29 E-23$ \\
\hline $12(g)$ & $3.6 ! E-0.1$ & 3. $61 E-01$ & $3.61 E-01$ & 3. $61 E-01$ & $3.61 E-01$ & $3.61 E-01$ \\
\hline $12(\theta)$ & 1. 25E-27 & 1. 25E-27 & 1. 25E-27 & 1. $25 E-27$ & 1. 2EE-27 & $1.25 E-27$ \\
\hline $\cos (g)$ & 2. (IIE-OI & 2. $01 E-01$ & $2.01 E-01$ & $2.01 E-01$ & $2.01 E-01$ & $2.01 E-01$ \\
\hline $20(g)$ & $1.7 \% E-01$ & $1.7 \% E-01$ & 1. $79 E-01$ & 1.79E-01 & $1.79 E-01$ & $1.795-01$ \\
\hline$(H 2 D) 2(g)$ & $1.95 E-05$ & $2.95 E-05$ & 1. 95E-05 & $1.95 E-05$ & $1.95 E-05$ & $1.955-05$ \\
\hline$(g)$ & 1.5\%-01 & $1.995-01$ & 1.97E-01 & $1.99 E-01$ & $1.99 E-01$ & $1.59 E-01$ \\
\hline OHA $(g)$ & 9. $132 t=09$ & $9.62 x-09$ & $9.62 E-09$ & $9.62 E m 09$ & $9.62 E-09$ & $9.62 E-09$ \\
\hline$(L 1 O H) 2(B)$ & $2.87 E-11$ & $2.87 E-11$ & 2. BTE-11 & 2. $87 E-11$ & 2. B7E-11 & 2. $87 E-11$ \\
\hline $0+1420(9)$ & $5.91 E-09$ & 5. $91 E \rightarrow 09$ & $5.91 E-09$ & $5.91 E-09$ & $3.92 E-09$ & $5.91 E-09$ \\
\hline $1 C l(g)$ & $1.05 E-09$ & 1. 0SE -09 & $1.05 E-09$ & $1.055-09$ & $1.05 E-09$ & 1.05E-09 \\
\hline g) & 2. J5E -09 & $2.35 E-04$ & 2. 35E-09 & 2. J5E -09 & 2. 35E- -09 & 2. J5E-09 \\
\hline $10 H(g)$ & 1. $3 ! E-07$ & 1. $31 E-07$ & $1.31 E-07$ & $1.31 E-07$ & 1. 31E-07 & $1.31 E-07$ \\
\hline$(X 0 H) 2(g)$ & 1. $37 E-11$ & 1. 37E-11 & $1.37 \mathrm{E}-11$ & 1.J7E-11 & $1.37 E-11$ & $1.37 \mathrm{E}-11$ \\
\hline $120(g)$ & 4. CBE-09 & 4.09E-109 & A. 09E-09 & 4. $09 E-09$ & $4.09 E-09$ & $4.09 E-09$ \\
\hline$C l(g)$ & 2. 28E -07 & $2.28 E-07$ & $2.2 B E-07$ & $2.28 E-07$ & $2.28 E-07$ & $2.28 E-07$ \\
\hline$v 1 C 2$ (g) & $6.10 \leq-19$ & 6. $10 E-19$ & $6.10 E-19$ & 6. 10E-19 & 6. 10E-19 & $6.10 E-19.4$ \\
\hline C12 (g) & $2.24 E-21$ & $2.24 E-21$ & $2.24 E-21$ & 2.24E-21 & $2.24 E-21$ & $2.2 A E-21<$ \\
\hline $\operatorname{cl2}(g)$ & $0.0 \times E+\infty O$ & $7.76 E-17$ & 3. B2E-16 & $7.76 E-16$ & 1. $16 E-15$ & $1.34 E-15<$ \\
\hline$(g)$ & 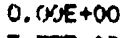 & 1. $01 E=06$ & 4. $99 E-06$ & $1.01 E-05$ & 1.5IE-05 & $2.01 E-05$ \\
\hline & 5. T7E-05 & 3. 37E-05 & 5. $37 \mathrm{E}-05$ & 5. J7E-OS & $5.37 E-05$ & $5.37 t 5-05$ \\
\hline $1(g)$ & 1. (1)E-08 & $1.01 E-09$ & $1.01 E-00$ & $1.01 E-O B$ & $1.01 E-08$ & $1.02 E-00$ \\
\hline
\end{tabular}

B. EFFECT OF COMEINED $\mathrm{an}+$ BCl ON ELECTROLXTE ACTIVITTES

\begin{tabular}{|c|c|c|c|c|c|c|}
\hline $\begin{array}{l}\text { L12C03 } 11) \\
\operatorname{LiOH}(1)\end{array}$ & $\begin{array}{l}2.37 E-01 \\
9.15 E-03\end{array}$ & $\begin{array}{l}\text { 2. } 37 E-11 \\
9.15 E-03\end{array}$ & $\begin{array}{l}\text { 2. } 37 E-01 \\
9.15 E-03\end{array}$ & $\begin{array}{l}\text { 2. } 37 E-01 \\
9.15 t-03\end{array}$ & $\begin{array}{l}2.37 \mathrm{E}-01 \\
9.15 \mathrm{E}-03\end{array}$ & $\begin{array}{l}2.37 E-01 \\
9.15 E-03\end{array}$ \\
\hline $\operatorname{LiCl}(1)$ & 3. $1 \mathrm{TE}-05$ & $3.07 E-05$ & $3.07 E-05$ & $3.07 E-05$ & 3.07E-05 & $3.07 E-05$ \\
\hline $\operatorname{Li20(1)}$ & $1.17 E-16$ & $1.17 E-06$ & $\ln 17 E-06$ & $1.17 E-06$ & 1.17E-Ob & $1.17 E-06$ \\
\hline$\times 2 \cos (1)$ & $7.32 E-02$ & 7. $32 E-02$ & 7. 3ZE-02 & 7. $32 E-02$ & $7.32 E-02$ & $7.32 E-02$ \\
\hline $\mathrm{KOH}(1)$ & E. $82 E-04$ & 5. $82 E-04$ & 3. $82 E-04$ & Q22E-04 & $5.82 E-04$ & $5.82 E-0.4$ \\
\hline $\operatorname{ked}(1)$ & $9.50 E-03$ & $9.58 E-03$ & 9. $5 B E-03$ & $58 E-03$ & $9.58 E-03$ & $9.5 B E-03$ \\
\hline K20(1) & $1.37 E-15$ & $1.37 E-15$ & $1.37 \mathrm{E}-15$ & 1. $37 E-15$ & 1. $37 E-15$ & $1.37 E-15$ \\
\hline $\mathrm{NiCO}(1)$ & $2.16 E-03$ & 2. $16 E-09$ & $2.165 .-09$ & $2.16 E-69$ & $2.16 E-09$ & $2.16 E-09$ \\
\hline$N 1(O H) \geq(s)$ & 3. 3CE-OB & 3. $30 E-0.8$ & $3.30 E-08$ & 3. 30E-CB & $3.30 E=08$ & 3.30E- -18 \\
\hline $\mathrm{NiCl2}(1)$ & 2. $14+E-19$ & $2.04 E-19$ & $2.04 E-19$ & 2. $04 E-19$ & $2.04 E-19$ & $2.04 E-19$ \\
\hline NiO(I) & 5. $1 B E-\infty E$ & 3. $185-05$ & 3. $18 E-05$ & 5. $18 E-05$ & $5.18 E-05$ & $5.18 E-0.5$ \\
\hline $2 n \operatorname{Cos}(8)$ & $0.0 \times E+00$ & 8. $18 E-O B$ & 4. $03 E-07$ & B. 18E-07 & $1.22 E-06$ & $1.62 E-06$ \\
\hline $3 n(\mathrm{OH}) 2(\mathrm{~s})$ & $0.1 K E E+60)$ & 1. $18 E-07$ & 5. $79 E-07$ & $1.18 E-06$ & 1.75E-06 & $2.33 E-06$ \\
\hline $2 n C 12(1)$ & $0.005+00$ & $2.82 E-16$ & $1.39 E-15$ & $2.82 E-15$ & $4,205-15$ & \\
\hline $2 n 0(1)$ & $0 .(1 B E+\infty)$ & $5.87 E-03$ & 2. $199 E-02$ & 5. $87 E-02$ & $0.75 E-02$ & $1.16 E-01$ \\
\hline
\end{tabular}

\section{EPFECTS ON IONIC COMPOSITION OF THE MELT}

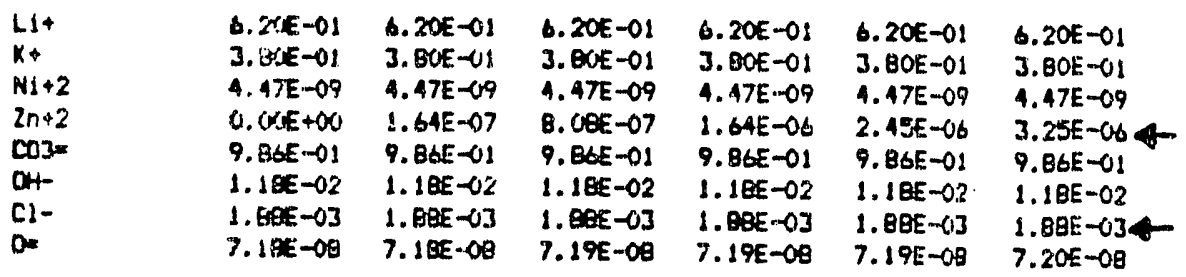

SPECIES PRESENT AS PURE CONDENSEU PAHASE:

Hi (cr) yes yes yes yes yes you 
TABLE IV• 3

A. BAS SFECIES PARTIAL PRESSURES (ATM)

\begin{tabular}{|c|c|c|c|c|c|c|}
\hline$N_{2}(g)$ & 5. $96 E-02$ & $3.985-02$ & 5.98E-02 & $5.90 E-02$ & $3.98 E-02$ & 5.98E-02 \\
\hline $02(8)$ & $1.32 E-23$ & 1. $32 E-23$ & $1.32 x-23$ & $1.328-23$ & $1.32 E-23$ & $1.32 x-23$ \\
\hline$H 2(g)$ & $3.60 t-01$ & 3. $60 E-01$ & $3.60 E-01$ & $3.60 \varepsilon-01$ & $3.60 E-01$ & $3.60 E-01$ \\
\hline $\operatorname{Cl2}(\theta)$ & $1.27 E-23$ & $1.2 \pi E-23$ & 1. $27 \mathrm{E}-23$ & $1.2 \pi E-23$ & $1.27 E-23$ & $\ln 27 \mathrm{E}-23$ \\
\hline $\cos 2(\theta)$ & $2.02 E-01$ & $2.02 E-01$ & $2.0225-01$ & $2.028-01$ & $2.02 E-01$ & $2.02 E-01$ \\
\hline $9120(g)$ & $1.80 E-01$ & $1.00 E-01$ & $1.00 E-01$ & $1.80 E-01$ & 1. BOE-01 & 1. $80 E-01$ \\
\hline$(1-2012(g)$ & $1.98 \varepsilon-05$ & $1.90 E-05$ & $1.98 E-05$ & 1. $9 B E-05$ & 1.9AE-05 & $1.98 E-05$ \\
\hline$\infty(\theta)$ & $1.70 E-01$ & 1. $7 E E-01$ & 1. 7es-01 & 1. TEE-01 & 1. $98 E-01$ & $1.98 E-01$ \\
\hline L.1OH(g) & $9.07 E-09$ & $9.07 E-09$ & 9.07E-09 & $9.07 E-09$ & $7.07 E-09$ & $9.07 E-09$ \\
\hline$(L)(O H) 2(g)$ & 2. $5 x=-11$ & $2.55 E-11$ & 2. $55 E-11$ & $2.55 E-11$ & 2.5SE-11 & $2.53 E-11$ \\
\hline $\operatorname{LIOH} 20(\mathrm{~g})$ & $5.60 E-09$ & $3.60 E \cdot 109$ & 3. $60 E-09$ & 5. $60 E-09$ & $3.60 \varepsilon-09$ & 5. $20 E-09$ \\
\hline 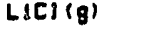 & $4.97 x-\infty$ & $9.72=-\infty$ & $9.72 E-00$ & $9.72 E-0 B$ & $9.92 z-08$ & $9.92 z-08$ \\
\hline$K(\theta)$ & $1.1 \% E-09$ & $1.17 E-\infty 9$ & $1.19 E-09$ & $1.14 E-09$ & $1.19 E-09$ & $1.19 E-09$ \\
\hline$K O H(8)$ & $6.6 . T E-\infty$ & $0.67 E-00$ & $6.67 \mathrm{E}-00$ & $6.67 E-08$ & $6.68 E-00$ & $0.68 E-08$ \\
\hline$(K D H) 2(g)$ & 3. $56 \varepsilon-12$ & $3.56 E-12$ & $3.5 x E-12$ & 3. $56 E-12$ & $3.56 E-12$ & $3.56 E-12$ \\
\hline KOH $120(g)$ & 2. $1 D E-09$ & $2.10 z-09$ & $2.10 E-09$ & 2. 10E-09 & $2.10 E-09$ & $2.10 E-09$ \\
\hline$x \in I(g)$ & $1.1 \mathrm{TE}-0 \mathrm{~s}$ & $1.17 E-05$ & $1.17 E-05$ & 1.17E-OS & $1.17 E-05$ & $1.17 E-05$ \\
\hline $\mathrm{NSCl}(\mathrm{g})$ & $6.15 z-17$ & $6.15 E-17$ & $6.15 E-17$ & $6.15 E-17$ & $6.15 E-17$ & $6.15 E-17$ \\
\hline Nicle (g) & $2.26 E-17$ & $2.28 E-17$ & $2.20 E-17$ & $2.28 E-17$ & $2.206-17$ & $2.28 E-17$ \\
\hline $\ln C 12(g)$ & $0.0 D E+D$ & $7.7 \%$ - 13 & $3.83 E-12$ & $7.78 E-12$ & $1.16 E-11$ & $1.94 E-11$ \\
\hline $2 n(g)$ & $0.0 X E+\infty$ & $9.99 E-07$ & $4.922-06$ & $9.99 E-06$ & $1.49 E-05$ & $1.985-05$ \\
\hline Nos $(g)$ & 5. J4E-05 & $5.34 E-05$ & $5.34 E-03$ & $5.34 k-05$ & $5.34 E-05$ & $5.34 E-03$ \\
\hline $\operatorname{HCl}(\theta)$ & $1,0 x-\infty$ & $1.02 z-06$ & $1.02 E-06$ & $1.025-06$ & $1.025-06$ & $1.02 E-06$ \\
\hline
\end{tabular}

B. EPPECTS OF CONBINED $\mathrm{zn}+$ ACl ON ELECTROLYTE ACTIVITIES

\begin{tabular}{|c|c|c|c|c|c|c|}
\hline $1.12 \cos (1)$ & 2. $11 E-01$ & 2. $11 E-01$ & 2. 11E-01 & 2. 11E-01 & $2.11 E-01$ & $2.21 E-01$ \\
\hline $\operatorname{LIOH}(1)$ & 8. $62 E-03$ & 0. $6 x[-0]$ & 8. $62 E-03$ & $0.62 E-03$ & $0.62 E-03$ & B. $6.2 E=03$ \\
\hline $\operatorname{LiCl}(1)$ & $2.915-03$ & $2.90 E-03$ & $2.90[-03$ & 2. 90E-03 & $2.90[-0]$ & $2.90 E-03$ \\
\hline Lizn(1) & $1.04 E-06$ & $1.04 E-06$ & $1.04 E-06$ & $1.04 E-06$ & $1.04 E-06$ & $1.04 E-06$ \\
\hline$\times 2 \cos 3(1)$ & $1.91 E-02$ & $1.91 E-0.2$ & $1.91 E-02$ & $1.91 E-02$ & $1.71 E-02$ & $1.91 E-02$ \\
\hline $\mathrm{KOH}(1)$ & $2.97 E-04$ & $2.97 E-04$ & $2.97 E-04$ & $2.97 E-04$ & $2.97 E-04$ & $2.97 E-04$ \\
\hline $\mathrm{K} C \mathrm{~L}(1)$ & $4.90 E-01$ & $4.90 E-01$ & $0.90 E-01$ & $4.90 E=01$ & $4.90 E-01$ & $4.90 \varepsilon-01$ \\
\hline$K 20(1)$ & $3.54 E-16$ & 3. $55 E-16$ & 3. 5SEE- 16 & 3. $55 E-16$ & $3.55 E-16$ & $3.55 E-16$ \\
\hline $\operatorname{Nicos}(1)$ & $2.20 \varepsilon-09$ & 2. 19E- 09 & 2. $19 E-09$ & 2. 19E-09 & $2.19 E-09$ & $2.19 E-09$ \\
\hline $\mathrm{Ni}(\mathrm{ON}) 2(\mathrm{~s})$ & $3.35 x-08$ & 3. 3SE-OQ & 3. $35 E-08$ & 3. $35 E-08$ & 3. JSE-08 & 3. 35E-08 \\
\hline Niclz 113 & $2.10=-15$ & $2.08 E-15$ & 2. $09 E-15$ & 2. $00 E-19$ & $2.08 E-15$ & $2.08 E-15$ \\
\hline N1O(1) & 5. $22 x-03$ & $5.22 x-05$ & $5.202-05$ & $5.222-05$ & $5.22 E-05$ & $5.22 E-05$ \\
\hline $\operatorname{InCOJ}(s)$ & $0.00 E+\infty 0$ & 8. $18 E-08$ & $4.0 \pi E-07$ & 6. $18 E-07$ & $1.22 E-06$ & $1.62 E-06$ \\
\hline $\operatorname{Zn}(\mathrm{OH}) 2(\mathrm{~s})$ & $0.0 x \in+00$ & 1. 1 at -07 & $5.79 E-07$ & $1.18 E-06$ & $1.75 f_{n}-06$ & $2.33 t-06$ \\
\hline $\operatorname{lnc} 12(1)$ & $0.00 E+\infty$ & 2. $83 E-12$ & 1. JPE- 11 & $2.8 x-11$ & $4.22 E-11$ & $3.60 E-11$ \\
\hline $\ln D(1)$ & $0.100 E+\infty$ & 5. BAE-03 & 2. $88 E-02$ & 5. $84 E-02$ & $8.71 E-02$ & $1.16 E-01$ \\
\hline
\end{tabular}

C. EPPECTS ON IONIC COAPOSITION OP THE METT

\begin{tabular}{|c|c|c|c|c|c|c|}
\hline $\begin{array}{l}\mathrm{LIt} \\
\mathrm{K}+\end{array}$ & $\begin{array}{l}\text { 1. } 20 E-01 \\
\text { 3. } 0 x E-0 \text { ! }\end{array}$ & $\begin{array}{l}6.20 E-01 \\
3.00 E-01\end{array}$ & $\begin{array}{l}\text { C. } 20 E-01 \\
3.00 E-01\end{array}$ & $\begin{array}{l}\text { 6. } 20 E-01 \\
\text { 3. 0OE }-01\end{array}$ & $\begin{array}{l}6.20 E-01 \\
3.00 E-01\end{array}$ & $\begin{array}{l}6.20 E-01 \\
3.80 E-01\end{array}$ \\
\hline $\mathrm{N} 1+2$ & $\sin 45 E-09$ & $1.49 E-C \theta$ & $1.44 E-08$ & $1.44 E-00$ & $1.44 E-08$ & $1.44 E-0 B$ \\
\hline $\begin{array}{l}2 n+2 \\
\cos =\end{array}$ & $\begin{array}{l}0.00 E+00 \\
8.36 E-01\end{array}$ & $\begin{array}{l}4.325-07 \\
0.365-01\end{array}$ & $\begin{array}{l}2.12 E-06 \\
8.35 E-01\end{array}$ & $\begin{array}{l}\text { 4. } 33 E-06 \\
0.36 E-01\end{array}$ & $\begin{array}{l}6.43 E-06 \\
8.36 E-01\end{array}$ & $\begin{array}{l}0.55 E-06 \% \\
0.365-01\end{array}$ \\
\hline OM- & $1.26 \sqrt{2}-02$ & $1.2 \Delta \mathrm{F}-02$ & $1.285-02$ & 1. 2\&E-02 & $1.26 E-02$ & $1.26 f-02$ \\
\hline $\begin{array}{ll}\mathrm{Cl}- \\
\mathrm{D}=\end{array}$ & $\begin{array}{l}1.51 E-01 \\
0.8 E E-00\end{array}$ & $\begin{array}{l}1.51 E-01 \\
0.90 E-0 B\end{array}$ & $\begin{array}{l}1.31 E-01 \\
9.91 E-03\end{array}$ & $\begin{array}{l}1.31 E-01 \\
0.92 x-00\end{array}$ & $\begin{array}{l}1.31 E-01 \\
6.93 E-09\end{array}$ & $\begin{array}{l}1.31 E-01= \\
0.94 E-08\end{array}$ \\
\hline
\end{tabular}

gPteIES PRESENT AS MURE CONGENSED PHASEs:

Ny(cr) yes yos yes yes yes yes 


\section{TABLE IV 4}

A. EAS SFECIES PARTIA PRESSURES (ATMi

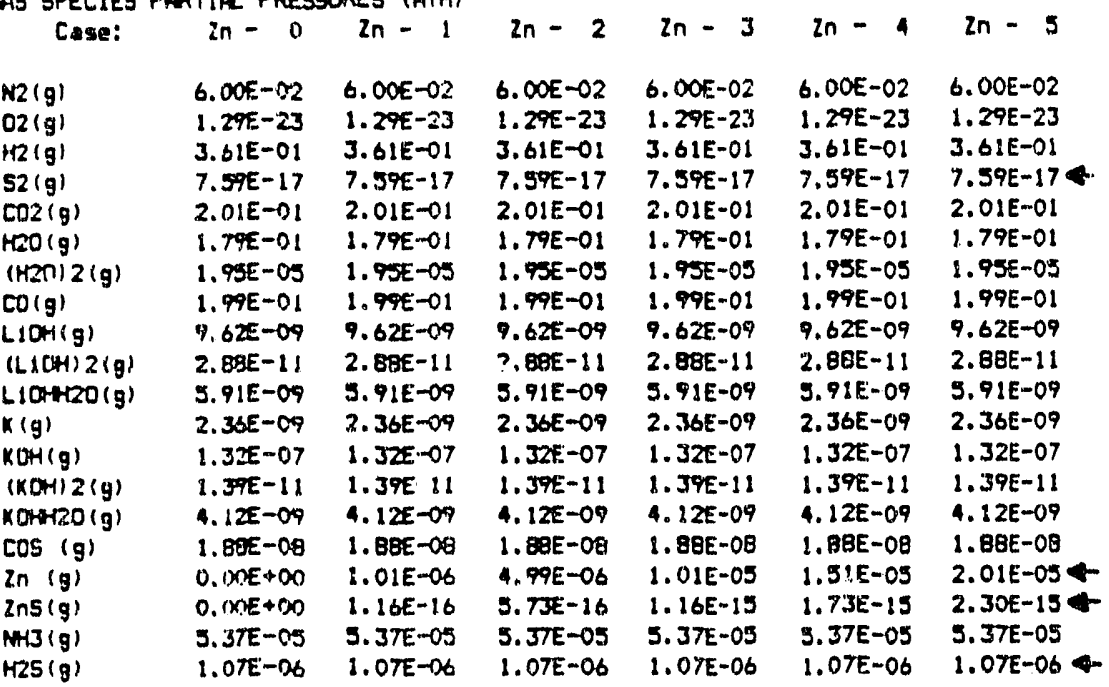

B. EPPECTS OF COMBINED $\mathrm{zn}+\mathrm{BzS}$ on electrolyte activities

\begin{tabular}{|c|c|c|c|c|c|c|}
\hline $\operatorname{Li2} 2003(1)$ & 2. $37 \mathrm{E}-01$ & 2. $37 E-01$ & 2. $37 E-01$ & 2. J7E-OI & 2. $37 \mathrm{E}-01$ & 2. $37 \mathrm{E}-01$ \\
\hline LIOH(1) & $9.15 E-0]$ & $9.15 \mathrm{E}-03$ & {$[.15 E-03$} & 9. $15 E-03$ & $9.15 E-03$ & $9.15 E-03$ \\
\hline $\operatorname{Li2s}(1)$ & $3.77 E-O 6$ & $3.97 \mathrm{E} \circlearrowleft \zeta$ & $3.97 E-06$ & $3.97 \mathrm{E}-116$ & $3.97 E-06$ & $3.97 E-06$ \\
\hline $\operatorname{Li20}(1)$ & $1.19 E-106$ & 1. 1 BE $\measuredangle 16$ & $1.18 E-O B$ & 1. $18 E-0.6$ & $1.18 \mathrm{E}-06$ & 1. $1 \mathrm{EE}-0 \mathrm{t}$ \\
\hline Li2504(1) & J.15E-14 & 5. $155-14$ & $5.15 E-14$ & $3.15 E-14$ & $5.15 E-14$ & $5.15 E-14$ \\
\hline$x 2 \cos (1)$ & $7.44 E-02$ & 7. $44 E-02$ & 7. $44 E-02$ & 7. $44 E-02$ & $7.44 E-02$ & 7. 44E- \\
\hline $\mathrm{KOH}(1)$ & $5, B, E-04$ & 5. $86 E-(14$ & 5. B6E-O4 & 5. BSE-OA & $5.06 \mathrm{E}-04$ & $5.86 E-04$ \\
\hline $25(1)$ & 1. $44 E-07$ & 1. $44 E-07$ & $1.44 E-07$ & $1.44 E-07$ & $1.44 E-07$ & $1.44 E-07$ \\
\hline$K 20(1)$ & 1. JYE - 15 & $1.39 E-15$ & $1.39 E-15$ & 1. .J9E-15 & $1.39 E-15$ & $1.395-15$ \\
\hline$\times 2504(1)$ & $1.72 E-11$ & $1.7 Z E-11$ & $1.7 Z E-11$ & $1.72 E-11$ & $1.72 E-11$ & $1.72 E-11$ \\
\hline $\operatorname{NiCOS}(1)$ & $2.16 E-09$ & 2. $16 E-199$ & 2. $16 E-09$ & $2.16 E-69$ & $2.16 E-09$ & 2. $16 E-09$ \\
\hline$N 1(D+4) 2(s)$ & ]. $30 E-O B$ & $3.30 E-09$ & $3,30 E-00$ & 3. $30 E-00$ & 3. उOE $O B$ & $3.30 E-C B$ \\
\hline Nis(1) & $4.43 E-05$ & $4.43 E-O E$ & $4.43 E-05$ & 4. 4JE-OS & $4.43 E-05$ & $4.4 .3 E-05$ \\
\hline$N 10(1)$ & $5,18 E-05$ & 5. $18 x-0^{*}$ & $5.18 E-O S$ & 5. $18 E-O S$ & 5. $1 \mathrm{EE}-03$ & 5. $1 \mathrm{BE}-0 \mathrm{~S}$ \\
\hline NiSD4 (s) & 9. OAE-24 & $9.04 E-24$ & $9.04 E-24$ & 9. $04 E-24$ & $9.04 E-24$ & $9.04 E-24$ \\
\hline $\ln \mathrm{CO}_{3}(\mathrm{~s})$ & $0 .(K J E+\infty)$ & 8. $1 Q E-C B$ & $4.03 E-07$ & 0. $18 E-07$ & $1.22 E-06$ & $1.62 E-06$ \\
\hline $\ln (04) 2(5)$ & $0 .(x E+\infty)$ & 1. $1 \mathrm{EE}-07$ & 5. TYE-O7 & 1. $18 \varepsilon-06$ & 1.75E-0.6 & 2. JJE-OS \\
\hline $\ln 5(1)$ & $0.1 V E+\infty 0$ & $2.20 E-0.4$ & 1. CEE -03 & 2. $20 k-03$ & 3. $2 \theta E-03$ & $4.36 E-03$ \\
\hline $2 n 0(1)$ & 0. $(\alpha E+\infty)$ & 5. $87 E-03$ & 2. $09 E-02$ & 5. $87 \mathrm{E}-02$ & $0.7 \mathrm{EE}-02$ & 1. $16 E=01$ \\
\hline inso4 (ter) & $0.00 E+\infty$ & $2.245-23$ & $1.10 E-22$ & $2.24 E-22$ & 3. $34 E-22$ & 4. $44 E-22$ \\
\hline
\end{tabular}

\section{EPFECTS ON IONIC COMPOSITION OP TEE MEL'T}

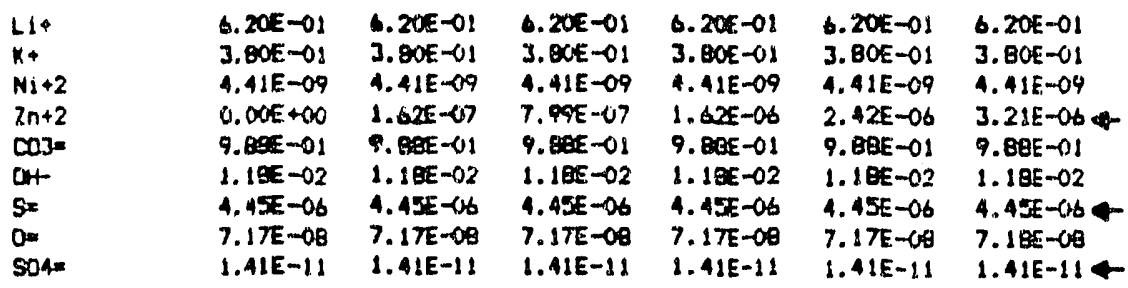

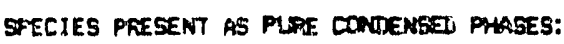

Ni(er) yes yous yes yes yes yes 
TABLE IV•5

A GAS SPECIES PARTIAL PRELSSAES (ATM)

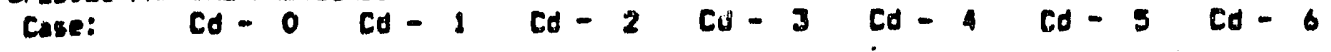

\begin{tabular}{|c|c|c|c|c|c|c|c|}
\hline$N 2(g)$ & . $\operatorname{COE}-02$ & $6.00 E-02$ & $6.00 E-02$ & $6.00 E-02$ & $6.00 E-02$ & $6.00 E-02$ & $6.00 E-02$ \\
\hline $02(9)$ & . $29 E-23$ & 3. $3 \% E-2 J$ & 1.25E-23 & $1.27 E-23$ & 1. 29E-23 & $1.29 E-23$ & $1.29 E-23$ \\
\hline $\mathrm{H} 2(\mathrm{~g})$ & 3. $61 E-01$ & J.G1E-OI & $3.61 E-01$ & $3.61 E-01$ & $3.61 \mathrm{E}-01$ & 3.61E-01 & $3.61 E-01$ \\
\hline $\cos 2(g)$ & $2.01 E-08$ & $2.01 E-01$ & 2.01E-01 & 2.01E-01 & $2.03 E-01$ & $2.01 E-01$ & $2.01 E-01$ \\
\hline$H 20(0)$ & .7\%E-01 & 1.79E-01 & $1.7 \% E-01$ & 1. TYE-01 & $1.79 E-01$ & $1.79 E-01$ & $1.79 E-02$ \\
\hline$(H z O) / 2(g)$ & 1. 9WE-OS & 1. $95 x-05$ & $1.95 E-05$ & 1. $95 E-05$ & $1.75 E-09$ & 1.TSE-OS & 1. 93e-05 \\
\hline $\cos (g)$ & $1.99 E-01$ & 1. PFE-01 & $1.9 \% E-01$ & $1.98 E-01$ & 1. $99 E-01$ & $1.99 E-01$ & $1.99 E=01$ \\
\hline LIOH $(g)$ & $9.62 E-09$ & $9.625-09$ & $9.6 \pi E-09$ & $9.62 E-09$ & $9.62 x-09$ & $9.62 E-09$ & $9.62 E-09$ \\
\hline (L1OH) $2(g)$ & 2. $80 E-11$ & $2.8 B E-11$ & 2. BeE -11 & 2. $88 E-11$ & 2. $86 E-11$ & $2.08 E-11$ & 2. BBE-11 \\
\hline $110 * 120(g)$ & $5.91 E-0.9$ & $5.91 E-09$ & $5.91 E-09$ & $5.91 E-09$ & $5.91 E-09$ & $5.91 E-09$ & 3.91E-09 \\
\hline (g) & $2.36 E-0.7$ & $2.36 E-099$ & $2.36 E-09$ & $2.36 E-09$ & $2.36 E-09$ & $2.36 E-109$ & $2.37 E-04$ \\
\hline $\mathrm{COH}(\mathrm{g})$ & $\ln 3 x=-07$ & $1.3 x=-07$ & 1.32E-07 & $1.3 x=-07$ & $1.32 E-07$ & $1.32 E-07$ & $1.32 E-07$ \\
\hline$(K D+1) 2(g)$ & $1.39 E-11$ & 1.39E-11 & $1.39 E-11$ & $1.39 E-11$ & 1.39E-18 & $1.39 E-11$ & $1.39 E-11$ \\
\hline$K O H+20(g)$ & $4.12 E-0$ : & $1,1< \pm-09$ & $4.12 E-09$ & $4.12 E-09$ & $4.12 E-09$ & $4.12 E-09$ & 4. $12 E-09$ \\
\hline $\cos (\theta)$ & $0.00 E+00$ & $1.00 E-07$ & $5.00 E-07$ & $1.00 E-06$ & $3.00 E-06$ & $1.00 E-08$ & $2.00 E-054$ \\
\hline$A+B(g)$ & $3.37 E-05$ & J. JTE-0S & 5.37E -03 & $5.37 E-05$ & $5.37 E-05$ & 5.37E-05 & 3.37E-05 \\
\hline
\end{tabular}

B. EPFECTS OP CA ON ELECTROLYTE ACTIVITIES AS MOLECULAR SPECIES

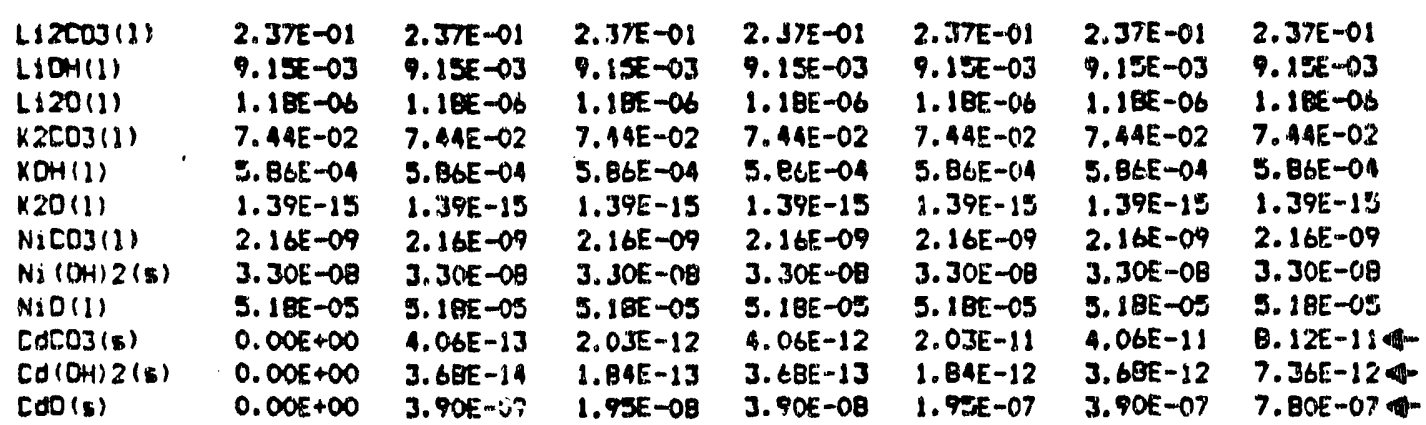

\section{EFPECTS ON IONIC COMPOSITION OF TAE MELT}

\begin{tabular}{|c|c|c|c|c|c|c|c|}
\hline $\begin{array}{l}\mathrm{Li}+ \\
\mathrm{K}+\end{array}$ & $\begin{array}{l}\text { 6. 20E }-01 \\
\text { 3. } 80 E-01\end{array}$ & $\begin{array}{l}\text { 6. } 20 E-01 \\
\text { 3. BOE-O1 }\end{array}$ & $\begin{array}{l}\text { 6. 20E }-01 \\
3.80 E-01\end{array}$ & $\begin{array}{l}\text { 6. } 20 E-01 \\
\text { 3. } 60 E-01\end{array}$ & $\begin{array}{l}\text { 6. } 20 E-01 \\
\text { 3. } 00 E-01\end{array}$ & $\begin{array}{l}6.20 E-01 \\
3.80 E-01\end{array}$ & $\begin{array}{l}6.20 E-01 \\
3.80 E-01\end{array}$ \\
\hline $\mathrm{Ni}+2$ & $-4.41 E-09$ & $4.41 E-09$ & $1.41 E-09$ & 4. 4JE-OQ & $4.41 E-00$ & $4.41 E-09$ & 4. $41 E-09$ \\
\hline $\begin{array}{l}\mathrm{Cd}+2 \\
\cos =\end{array}$ & $\begin{array}{l}0.00 E+00 \\
9.8 B E-01\end{array}$ & $\begin{array}{l}\text { 7. B2E-13 } \\
\text { 9. BBE-0! }\end{array}$ & $\begin{array}{l}3.91 E-12 \\
9.8 B E-01\end{array}$ & $\begin{array}{l}\text { 7. BZE-12 } \\
9 . \text { EBE-01 }\end{array}$ & $\begin{array}{l}3.91 E-11 \\
9.88 E-01\end{array}$ & $\begin{array}{l}\text { 7. } B 2 E-11 \\
9.8 B E-01\end{array}$ & $\begin{array}{l}\text { 1.56E-101w } \\
9 . B B E-011\end{array}$ \\
\hline OH- & $\begin{array}{l}\text { 1. } 1 B E-02 \\
7.17 E-O B\end{array}$ & $\begin{array}{l}1.1 B E-02 \\
7.17 E-0 B\end{array}$ & $\begin{array}{l}1.1 B E-02 \\
7.1 \mathrm{TE}-O B\end{array}$ & $\begin{array}{l}1.1 \mathrm{BE}-02 \\
7.17 E-O B\end{array}$ & $\begin{array}{l}1.18 E-02 \\
7.17 E-O B\end{array}$ & $\begin{array}{l}\text { 1. } 1 B E-02 \\
7.17 E-08\end{array}$ & $\begin{array}{l}1.18 E-102 \\
7.17 E-08\end{array}$ \\
\hline
\end{tabular}

SFECIES FRESENT AS PURE. CONDENSED PHASES:

Ni $(e r)$ yes yes yes yes yes yes yes 
TABLE IV• 6

A. GAS SPECIES PAPT INL PRESTURES (ATM)

\begin{tabular}{|c|c|c|c|c|c|c|c|}
\hline Cane: & $C d-0$ & $C=1$ & Cd - & $\mathrm{Cd}-$ & $\cos -4$ & $\cos -$ & Co $\cdots$ \\
\hline$N(g)$ & $0.005-02$ & $6.00<-102$ & $0.200-02$ & $4.00 E=02$ & $6.00 \mathrm{~F}-\mathrm{moz}$ & $6.00 E-02$ & h. $00 E-02$ \\
\hline $02(g)$ & $1.29 \%-23$ & $1.2 \% E-2 \pi$ & $1.29 E-23$ & $1.245-23$ & $1.29 E-23$ & $1.29 E-23$ & $1.29:-23$ \\
\hline$M 2(g)$ & $3.61 E-01$ & J. $41 E-01$ & $3.61 E-01$ & $3.61 E-01$ & $3,61 E-01$ & $3,61 E-01$ & 3. $1 E-0$ : \\
\hline $\cos (g)$ & $1.2 m=27$ & $1.258-27$ & $1.25 x-27$ & $1.25 E-27$ & $1.25 E-27$ & $1.25 E+27$ & 1. $205-27$ \\
\hline $\cos (9)$ & $2.01 E-01$ & $2.01 E-01$ & $2.01 E-01$ & $2,01 E-01$ & $2.01 E-01$ & $2.01 E \rightarrow 1$ & $2.01 E-01$ \\
\hline$H 2 O(g)$ & $1.741-01$ & $1.79 t-01$ & $1.7 \% E-01$ & $1.79 E-01$ & $1.79 \mathrm{t} \cdot 01$ & $1.79 E-01$ & $1.79 t-01$ \\
\hline$(k 20) 2(g)$ & $1.95 x-03$ & $1.95 \mathrm{st}:-0 \mathrm{~s}$ & $1.95 E-05$ & $1.075 E-03$ & 1. 950 & 1. Pse-0s & $1.95 E-05$ \\
\hline $\mathrm{CO}(\mathrm{g})$ & 1. $99 E-01$ & $1 . \%+-01$ & $1.99 E-01$ & $1.99 E-01$ & $1.99 E-01$ & $1.99 E-01$ & $1.995-01$ \\
\hline $\operatorname{Lon}(g)$ & $9.62 x-09$ & $9.622-09$ & $4.6 x-0.7$ & $9.62 x=-09$ & $9.6 z=-09$ & $9,47 E-\infty 9$ & $9.62 E-0 \%$ \\
\hline (LIOH) 2 (g) & 2. 87E- -11 & $2.87 t-11$ & $2.8 \pi-11$ & 2. BTE-11 & 2. $67 E-11$ & $2.87 E-11$ & 2. BVE-11 \\
\hline LIAHzas $y)$ & $5,71 E-09$ & 5. 91 E. - DN & $3.91 E-09$ & $3.91 E-\infty$ & $=.9115 .09$ & $5.91 E-09$ & 7. $71 E-09$ \\
\hline $610 ! i g l$ & $1.05 x=-08$ & $1.05 *-0.9$ & $1.05 E-\infty 9$ & $1.0 x E-09$ & $1.05 x-09$ & $1.005-09$ & $1.05 E-09$ \\
\hline$k(g)$ & $2.3575-09$ & $2.358-09$ & 2. $35 x-09$ & $2.35 x-09$ & 2. J5E- 19 & 2. $35 E-09$ & $2.35 t-09$ \\
\hline KOH(g) & 1. $31 E-07$ & $1.315-07$ & $1.31 E-07$ & $1.31 E-07$ & $1.31 .6 \cdots 07$ & $1.31 E-07$ & $1.31 E=07$ \\
\hline$(X) Y H) 2(3)$ & $1.37 t-11$ & 1.3 rte-1! & $1,35-11$ & $1.37 E-11$ & $1.37 \mathrm{E}-11$ & $1.37 E-11$ & $1.37 E-11$ \\
\hline$x(0+20(9)$ & $4.0 \%=-09$ & $4.0 \%=-09$ & $4.04 z-07$ & $4.045-09$ & $4.04 E-109$ & $4.04 E-09$ & $4.096-09$ \\
\hline$x \in l(g)$ & $2.28<-07$ & $2.2 \mathrm{BE}-07$ & $2.28 E-07$ & $2.20=-07$ & $2.280-07$ & $2.2 \mathrm{BE}-07$ & $2.28 E-07$ \\
\hline NiCl" (g) & $0.100-10$ & $0.106-17$ & b. $10 F-19$ & $0.10 E-19$ & $6.10 E-14$ & $6.10=19$ & $0.100-19$ \\
\hline NiCl2 (g) & $2.245-21$ & $2.2 A E-21$ & $2.24 E-21$ & $2.24 E-21$ & $2.24 E-21$ & $2.24 \mathrm{E}-21$ & $2,2 A E-21$ \\
\hline $\operatorname{Co}(g)$ & $0.00 E+09$ & $1.000=07$ & $5.00 x-07$ & $1.00 E-06$ & $5.00 E-06$ & $1.00 E-05$ & $\therefore 005-05<$ \\
\hline$\pi(2(g)$ & $0.00 E+00$ & $1.305-31$ & $0.49 E-21$ & $1.30 E-20$ & $6.49 E-20$ & $1.30+-19$ & $2.60 \%-194$ \\
\hline $\operatorname{Mr}(g)$ & 9. $37 E-05$ & S. JTE -OS & $5.31 k-05$ & $5.57 E-05$ & S. 3rt:-05 & $3.57 E-0,5$ & 5. 37E m0S \\
\hline $\operatorname{Mcl}(g)$ & $1.01 E-08$ & $1.01 E-819$ & $1.01 k-20$ & $1.01 E-08$ & $1.01 E-00$ & $1.01 E-00$ & 1. $01.5-08$ \\
\hline
\end{tabular}

B. EPFECTS OF COMBINED CD + ECL ON FLECTROLYTE ACTIVITIES

\begin{tabular}{|c|c|c|c|c|c|c|c|}
\hline L. $12 \cos (1)$ & $2.37 E-01$ & 2. $37 \mathrm{E}-01$ & 2. $32 \mathrm{H}=-01$ & 2. STE-OI & 2. JTE-OI & 2. TTE $-O 1$ & 2. 37E -01 \\
\hline LiCH(1) & $9.15 x-03$ & $4.205-03$ & $9.15 x-03$ & $9.15 E-07$ & $9.15 E-03$ & $9.15=0.03$ & $9.23 z-0.3$ \\
\hline LICI 11 & 3. Ore $-0 \mathrm{~s}$ & 3. DTE. $-\infty$ & $3.07 E-03$ & 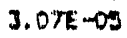 & $\$ .07 \mathrm{~F}-0 \mathrm{~S}$ & $3.07 E-C$ & $3.07 E-03$ \\
\hline 1.120111 & $1.17 E-06$ & $1.17 E-06$ & $1.17 E-06$ & $1.17 E-06$ & $1.17 E-36$ & $1.17 E-06$ & $1.17 E-06$ \\
\hline Katcosill & $7.32 E-02$ & 7. 3.2E -02 & $7.32 E-02$ & $7.37 E-02$ & 7. 3:E- 512 & $7.32 t-02$ & $7.32 E-02$ \\
\hline$K D H(1)$ & 5. B\&E-04 & $5.6 \%-04$ & $5.62 E-04$ & $5 . B C E=04$ & $\because .8<E \times 04$ & $5.82 E-04$ & 5. B.2E-0. \\
\hline$K C I(1)$ & 9. SBE -O3 & 9. $5 B E \times O Z$ & $0.58 E-03$ & 9. $\triangle E E-O J$ & $9.5 B E-03$ & $9.58 E-03$ & 7. $A B E-03$ \\
\hline$\times 20(1)$ & $1.37 E, \cdots 15$ & 1. $37 E+15$ & 1. $375-15$ & $1.3 / E-18$ & $1.37 E-15$ & $1.37 E-15$ & 1. $37 E-15$ \\
\hline$H_{2} \cos (1)$ & $2.16 E=09$ & 2.1650 .09 & $2.16 E-09$ & 2.105 .109 & $2.16 E-0.09$ & $2.16 \mathrm{E}-0.9$ & $2.16 E-09$ \\
\hline $\mathrm{Ni}(\mathrm{OH}) \mathrm{2} \mathrm{C}$ & $3.30 \mathrm{O}-\mathrm{OA}$ & $3.30=-00$ & $3.304:-08$ & $3.305-6.18$ & 3. $705-08$ & $3.30 E=06$ & 7. JOE-CB \\
\hline 41012 (1) & $2.04 k-19$ & 2. $0.4 E-19$ & $2.04 E-19$ & $2.04 E \times 19$ & $2.04 E-19$ & $3.04 E-19$ & 2. $0.4 E-19$ \\
\hline $\mathrm{N}_{2} \mathrm{O}(1)$ & 5. $1 \mathrm{BE}-O S$ & S. $18 E-C y$ & $5.1 B E-05$ & $5.18 E-05$ & $3.1 \mathrm{BE}-0 \mathrm{~S}$ & $3.28 E-0 \%$ & $5.28 \mathrm{r}-03$ \\
\hline T.uco. $1(x)$ & $0.00 E+00$ & $4.00 E-13$ & 2. $03 E-12$ & $4.56 E-12$ & $2.03 E-11$ & $4.065-11$ & Q.12E-116 \\
\hline$C a(O) 2(s)$ & $0.00 E+00$ & 3. $6 B E-14$ & $1.84 E-13$ & 3. $\angle B E-13$ & $1.84 E-12$ & 3. $6 \mathrm{QE}-12$ & $7.36 E-12$ \\
\hline (atizes) & $0.00 E+00$ & $9.62 E-20$ & $4.81 E-19$ & $9.62 E-19$ & $9.81 E-16$ & $9.62 E-18$ & $1.92 E-17$ \\
\hline $\operatorname{CED}(s)$ & $0.00 E+\infty 0$ & $3.906-09$ & $1.93 \mathrm{EE}-00$ & $3.40 E-08$ & $1.9 \mathrm{AE} \cdot 07$ & $3.90 E-07$ & $7.80 E-04$ \\
\hline
\end{tabular}

C. EFFECTS ON IONIC COMPOSITION OP THE MELT

\begin{tabular}{|c|c|c|c|c|c|c|c|}
\hline LA & $0.20 E-01$ & 6. $206-01$ & $6.20 E-01$ & D. . .OE -01 & $6.20 \mathrm{E}-08$ & $0.205-01$ & b. $20 E-01$ \\
\hline$x+$ & J. OOE -01 & $3.80 E-01$ & 3. $000-01$ & $3.005-01$ & 3. $\triangle O C-01$ & 3. BOE -OI & $3.00 E-01$ \\
\hline $\mathrm{N}_{1}+2$ & 4. A7E-TS & $4.4 \pi t-\infty 9$ & $4.17 E-\infty 9$ & $4.17 \%-09$ & $1.47 E-199$ & $4.4 \pi-09$ & $4.475-09$ \\
\hline$c \theta+2$ & $0.00 k+00$ & $7.91 E-13$ & $3.96 E \cdots 12$ & $7.91 E-12$ & $3.965-11$ & $7.91 E-11$ & 1. $. E E-10 D$ \\
\hline $\cos =$ & $9,0, E-01$ & $9,0.6 E-01$ & $9.8 \Delta E-01$ & $9.26 E-01$ & $9.8 \Delta E-01$ & 9. B6E-01 & $9.06 E-01$ \\
\hline Ont- & $1.18 C-02$ & $1.105-02$ & $1.18 x-02$ & 1. 1 剀 -.22 & $1,10 E-02$ & 1,1 EE-02 & $1.18 E-0$. \\
\hline cil- & $1.0885-03$ & 1. 0at -03 & 1. DSE -03 & 1. 4 aE-0J & $1.88[-0]$ & 1. BEE -0.3 & $1.88:-034$ \\
\hline Oitit & 7. $1 B E-08$ & $7.10 E-O B$ & $7.18 E-0 B^{3}$ & $7.18 E-08$ & $7,1 B E-O B$ & $3.18 E-0 \theta$ & $7.18 E-08$ \\
\hline
\end{tabular}

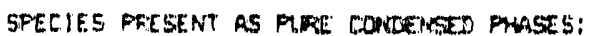

Ni(er) you you you yis y yos yes 
TABLE $\quad$ IV・7

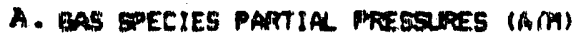

\begin{tabular}{|c|c|c|c|c|c|c|c|}
\hline CAch: & $C d-0$ & $C d-1$ & $C d-2$ & $c d-3$ & $\mathrm{Cd}=$ & $\mathrm{Cd}-$ & $\cos -$ \\
\hline (g) & 3. $9 B E-02$ & $5.98 E-02$ & 5. $405-02$ & 3. $40=02$ & $5.78 E \cdots .02$ & 5. 9 aE- 02 & 9.98E-02 \\
\hline (c) & $1.2 x-2 x$ & $1.3 x-23$ & 1.32 .23 & $1.32 E-25$ & $1.32 E-23$ & $1.325-23$ & $1.32 x-33$ \\
\hline (g) & $3.60 E-01$ & $3.606-01$ & $3.00 E=01$ & $3.60 E-01$ & $3.605-01$ & $3.60 E-01$ & $3.602-01$ \\
\hline $2(g)$ & $1.27 \mathrm{E}-73$ & 1. $27 E-23$ & $1.27 E-27$ & $1.2 \pi E-23$ & $1.27 E-23$ & $1.2 \pi 2$ & $1.27 E-23$ \\
\hline$(g)$ & $2.02 E-01$ & $2.02 x-01$ & $2.025 \cdot 01$ & $2.02 x-01$ & $2.02 E-01$ & 2.1"zE-01 & $2.02 E n-01$ \\
\hline$g(g)$ & 1.BOE-01 & 2. OOE-01 & 1. BxE-01 & $1.00 E-01$ & $1.005-01$ & 1. BOE-Od & $1.805-01$ \\
\hline 20$) 2(\mathrm{~g} !$ & $1.40 E-0.3$ & 1. $98 \mathrm{E}-0.5$ & 1. 'REE-DS & $1.9 B E-05$ & 1. $78 E-03$ & $1,40 E-05$ & $1.98 E-105$ \\
\hline$(g)$ & 1. $1910=-01$ & $1.905-01$ & 1.'HeE $=101$ & $1.98 E-O 1$ & $1.902-01$ & $1.98 F-01$ & 1. $\triangle B E-() 1$ \\
\hline $104(g)$ & $9.07 E-09$ & $9.07 E-09$ & $9.0,2-199$ & $9.07 E-09$ & $9.07 E-09$ & $9.07 E-09$ & $9.07 E-09$ \\
\hline 104$) 2(9$ & 2. $555-11$ & 2. $55 \times 11$ & $2.55 x-11$ & $2.55 x-11$ & 2. $505-11$ & $2,55 E-11$ & 2.5gie-11 \\
\hline $0+120(g)$ & $5.60=-09$ & 5. $00 E-09$ & $3 . \leqslant 0=-\infty$ & $5.60<-09$ & 5. $40 t-09$ & 5. $60 E-09$ & $5.60 E-09$ \\
\hline$C l(g)$ & $9.92 E=09$ & $9.922-00$ & $9.925-198$ & $9.92 \pi-08$ & $9.92 \mathrm{E}=08$ & $9.925-00$ & $9.92 \mathrm{E}-08$ \\
\hline & $1.19 k-09$ & $1.18 E-09$ & 1. $29 t-1) 9$ & 1. 19E-09 & $1.17 E-09$ & $1.27 E-09$ & $1.19:-09$ \\
\hline$t(g)$ & $6.67 E-00$ & $6.67 t-08$ & $6.671:-1) 8$ & $6.67 E-00$ & 6. $\triangle 77 E-08$ & B. $67 E-08$ & $0.67 E-08$ \\
\hline H) $2(\mathrm{~g})$ & $3.96 E-12$ & $3.54-12$ & 3.'3tE- 12 & 3. 5tE-12. & 3. $26 E-12$ & 3. \$SE-12 & $3.56 E-12$ \\
\hline $120(g)$ & $2.10=-09$ & $2.105-09$ & 2. $10 E-1) 9$ & 2. $10 E-09$ & 2. $10 \varepsilon-09$ & $2.10=-09$ & $2.105-09$ \\
\hline $1(g)$ & $1.17 E-05$ & 1. $1 \pi-\infty$ & $1.1 \pi-155$ & $1.8 \pi t-08$ & $1.1 \pi E-03$ & $1.17 \mathrm{~F}-0 \mathrm{~S}$ & 1.17E-OS \\
\hline f $(g)$ & $6.15 E-17$ & 6. $15=-17$ & $4.15 x-117$ & 6. $15 E-17$ & $6.13 E-17$ & $6.135-17$ & $6.15 E \cdot 17$ \\
\hline $\mathrm{Cl} 2(g)$ & $2.28 E-17$ & $2.28 E-17$ & $2.28 E-\| 7$ & 2. $2 \mathrm{BEE}-17$ & $2.28 E-17$ & 2. $29 x-17$ & $2.28 E-17$ \\
\hline & $0,00 E-00$ & $9.97 \mathrm{E}-0.0$ & 4. $48 E-(1) 7$ & $9.97 E-07$ & $4.98 E-06$ & $9.975-06$ & $1.99 E-05$ \\
\hline$\alpha 12(g)$ & $9.001=00$ & $1.32 x-17$ & $6.5 \%-117$ & $1.32 E-16$ & $6.59 E-16$ & $1.32 E-19$ & $2.64 E-15$ \\
\hline 8 & 5. 3AE-OS & 3. 34E-OS & 5. $34 E-1 / 3$ & 5. 34E-05 & ร. 3-4E-OS & 5. I.4E-OS & 5. 3AE-OS \\
\hline$c j(g)$ & $1.02 z-06$ & $1.0 x-06$ & $1.02 E-116$ & $1.0 x-06$ & $1.02 E-06$ & $1.025-06$ & $1.02 E-06$ \\
\hline
\end{tabular}

B. EPFECTS OF COMBTHED CA + HCI. ON JUECTROLYTE MCTIVTTIRS

\begin{tabular}{|c|c|c|c|c|c|c|c|}
\hline $\begin{array}{l}\operatorname{l}(3 \mathrm{COB}(1) \\
\operatorname{LiOH}(1) \\
\operatorname{liCl}(1)\end{array}$ & $\begin{array}{l}2.11 E-01 \\
8.62 E-03 \\
2.90 E-03\end{array}$ & $\begin{array}{l}2.11 E-01 \\
0.62 E-03 \\
2.90 E-03\end{array}$ & $\begin{array}{l}2.11 E-(1) 1 \\
8.62 E-113 \\
2.90 E-(1) 3\end{array}$ & $\begin{array}{l}2.11 E-01 \\
8.62 E-03 \\
2.90 E-03\end{array}$ & $\begin{array}{l}2.11 E-01 \\
8.6 Z-03 \\
2.0, E-03\end{array}$ & $\begin{array}{l}2.11 E-01 \\
8.62 E-03 \\
2.90 E-03\end{array}$ & $\begin{array}{l}2.11 E-01 \\
8.6 X E-03 \\
2.90 E-03\end{array}$ \\
\hline Li20(1) & $.1 .04 E=06$ & 1. $04 E-06$ & $1.04 E-126$ & $1.04 E-06$ & 1. $04 E-06$ & $1.04 E^{-06}$ & 1. $04 E-06$ \\
\hline$k 2 \cos : 1)$ & $1.91 E-02$ & $1.91 E-02$ & $1.91 E-102$ & $1.91 E-02$ & $1.91 E-02$ & $1.91 E-02$ & $1.91 E-02$ \\
\hline $\mathrm{KOH}(1)$ & 2.97E-04 & $2.97 E-04$ & $2.97 E-O 4$ & $2.47 E-0.4$ & 2. $97 E-04$ & $2.97 E-04$ & 2. $97 E-04$ \\
\hline$k(1)$ & $4.90 E-121$ & $4.90 E-01$ & 4. $90 E-101$ & $4.50 E-01$ & $4.90 E-01$ & $4.90 E-01$ & $1.90 E-01$ \\
\hline$\times 20(1)$ & $3.34 E-16$ & 3. 5SE-16 & $3.55 f-16$ & $3.55 E-16$ & $3.53 E-16$ & $3.55 E-16$ & $3.55 E-16$ \\
\hline $\mathrm{NiCO3}(\mathrm{d})$ & $2.20 E-09$ & $2.195-09$ & $2.1 \% E-\infty 9$ & $2.19 E-09$ & $2.89 E-09$ & 2. $19 E-09$ & $2.19 E-09$ \\
\hline $\mathrm{Ni}(\mathrm{OH}) 2(\mathrm{~s})$ & $3.35 E-\infty$ & 3. JSE-OB & $3.35 E-109$ & 3. $55 \mathrm{E}-08$ & $3.35 E-03$ & 3. JSE $-O B$ & $3.35 E-0.8$ \\
\hline NiCl2 (I) & $2.08 E-15$ & $2.08 E-15$ & 2. OBE-15 & $2.09 E-15$ & $2.08 E-15$ & 2. $0 \mathrm{BE}-1 \mathrm{~S}$ & 2.08E-15 \\
\hline $\mathrm{N} 1 \mathrm{O}(1)$ & $5.22 E-0 \%$ & $5.225-05$ & $5.22 E-05$ & $5.225-05$ & $5.22 E-03$ & $5.22 E-05$ & $3.22 E-0.5$ \\
\hline $\operatorname{cotos}(\mathrm{s})$ & $0.00 E+00$ & $1.10 E-13$ & $2.05 E \cdot 12$ & $4.10 \varepsilon-12$ & $2.055-11$ & $4.10 E-11$ & B. 2OE-11 \\
\hline $\operatorname{Cd}(\mathrm{OH}) 2(\mathrm{~s})$ & $0.00 E+\infty$ & $3.72 E-14$ & 1. B6E -13 & $3.726-13$ & $1.86 E-12$ & $3.72 E-12$ & $7.44 E-12$ \\
\hline $\operatorname{coc} 1211)$ & $0.00 E+\infty$ & $9.76 E-16$ & 4. BBE- -15 & $9.76 E-15$ & A. BBE-14 & $9.76 E-14$ & $1.45 E-13$ \\
\hline Cols & $0.00 E+\infty 0$ & $3.92 E-09$ & $1.965 \cdot 09$ & $3.925-08$ & $1.96 E-07$ & $3.92 E-07$ & 7. BAE -07 \\
\hline
\end{tabular}

C. RFPECTS ON IONIC COMPOSITIC: OR THE MELT

\begin{tabular}{|c|c|c|c|c|c|c|c|}
\hline Lit & $\begin{array}{l}\text { 6. } 20 E-01 \\
\text { 3. } 80 E-01\end{array}$ & $\begin{array}{l}0.20 E-01 \\
3.80 E-01\end{array}$ & $\begin{array}{l}6.20 E-01 \\
3.00 E=01\end{array}$ & $\begin{array}{l}\text { 6. } 20 E-01 \\
3.80 E-01\end{array}$ & $\begin{array}{l}\text { 6. 20E-01 } \\
3.00 E-01\end{array}$ & $\begin{array}{l}\text { 6. } 20 E-01 \\
3.30 E-01\end{array}$ & $\begin{array}{l}6.20 E-01 \\
3.00 E-01\end{array}$ \\
\hline $\mathrm{Ni}+2$ & $1.45 E-00$ & 1. $44 E-D 0$ & $1.4 \mathrm{AE} \backsim 0$ & $1.44 E-00$ & $1.44 E-O B$ & $1.44 E-0.9$ & 1. $44 E-08$ \\
\hline$C O+2$ & $0.00 E+00$ & 2. $04 E_{n}-12$ & $1.02 E \ln \$ 1$ & $2.02 E-11$ & $1.02 E-10$ & $2.04 E-10$ & $4.08 x-10<$ \\
\hline $\mathrm{CO} 3 \pi$ & B. $36 E-01$ & $0.36 E-01$ & $0.36[-01$ & 8. 36E-01 & B. $365-01$ & 8.36E-01 & $8.36 E-01$ \\
\hline OH- & $1.20 E-02$. & $1.26 E-02$ & 1. 2GE -02 & $1.26 E-02$ & $1.26 E-02$ & $1.26 E-0.2$ & $1.26 E-0.2$ \\
\hline $\begin{array}{l}C 1 \% \\
0=0\end{array}$ & $\begin{array}{l}\text { 1.51E-01 } \\
8.8 B E-08\end{array}$ & $\begin{array}{l}\text { 1.51E-01 } \\
\text { 8. } 90 E-08\end{array}$ & $\begin{array}{l}8.51 E-01 \\
0.90=-08\end{array}$ & $\begin{array}{l}1.51 E-01 \\
8.90 E-08\end{array}$ & $\begin{array}{l}1.51 E-01 \\
8.90 E-08\end{array}$ & 1.51E-01 & $\begin{array}{l}1.51 E-O 1 \\
\theta .90 E-O B\end{array}$ \\
\hline
\end{tabular}

SFRCIES PRESENT AS PIPRE COWDENSED PHASES:

Ni(er) yes yes yos yes yes yes yes 
TABLE IV・ 8

A. gas sFecies partia pRessures (ATM)

\begin{tabular}{|c|c|c|c|c|c|c|c|}
\hline Case: & $\mathrm{Cd}-\mathrm{O}$ & $C d-1$ & $C d-2$ & $\mathrm{CO}-3$ & $\mathrm{Cd}-$ & $\cos -$ & $\mathrm{Cd}-$ \\
\hline $2(g)$ & $6.00 E-02$ & $6.00 x=-02$ & $6.00 E-02$ & $6.006-02$ & $6.00 E-02$ & $6.00 E-02$ & $6.00 F-02$ \\
\hline & $1.29 E-23$ & 1.27E-23 & $1.29 E-23$ & $1.2 \%-23$ & $1.29 E-23$ & $1.29 E-23$ & $1.29 E-23$ \\
\hline & 3.61E-OI & $3.61 E-01$ & J.61E- O & $3.61 E-01$ & $3.61 E-01$ & 3.615 .01 & $3.6 ! E-01$ \\
\hline 219$)$ & $7.59 E-17$ & 7. 59E-17 & $7.59 E-17$ & $7.39 E-17$ & $7.59 E-17$ & $7.595-17$ & $7.59 E-17$ \\
\hline $\operatorname{COO} 2(\theta)$ & $2.01 E-01$ & $2.01 E-01$ & $2.01 E-01$ & $2.01 E-01$ & $2.01 E-01$ & $2.01 E-01$ & $2.01 E-01$ \\
\hline $20(8)$ & 1. $79 E-01$ & $1.79 E-01$ & $1.79 \varepsilon-01$ & $1.78 E-01$ & 1. TEE-OI & $1.79 E-01$ & $1.79 E-01$ \\
\hline $12012(8)$ & $1.95 x-05$ & $1.95 z-03$ & $1.95 E-05$ & $1.95:-05$ & $1.955-05$ & 1. $95 E-05$ & $1.95 E-05$ \\
\hline $\operatorname{co}(g)$ & $1.99 E-01$ & 1. 9QE -01 & $1.99 E-01$ & $1.7 F E-01$ & 1. PQE-Ol & 1. P9E-01 & $1.995-01$ \\
\hline $104(g)$ & $9.62 E-09$ & $9.62=-09$ & $9.62 E-09$ & $19.672-09$ & $9.62 E-09$ & $9.62 E-04$ & $9.62 E-09$ \\
\hline (LIOH) $2(g)$ & 2. $99 E-11$ & 2. $218 E-11$ & 2. $88 E-11$ & $2.895-11$ & 2. $68 E-11$ & 2. $8 B E-11$ & 2. $88 E-11$ \\
\hline Bontroo (g) & $3.91 E-09$ & 5. $91 E-09$ & $5.91 E-09$ & $5.91 E-09$ & $5.91 E-09$ & $9.91 E-09$ & $5.91 E-09$ \\
\hline$x(g)$ & $2.36 E-09$ & $2,36 E-09$ & $2.36 F-09$ & 2. ISE-09 & $2.36 E-09$ & $2.36 E-09$ & $2.36 E-09$ \\
\hline $\operatorname{KOH}(g)$ & $1.3 x-07$ & $1.3 x-07$ & $1.32 E-07$ & 1.32E-07 & $1.32 E-07$ & $1.32 E-07$ & $1.32 E-07$ \\
\hline$(\mathrm{KOH}) 2(\mathrm{~g})$ & 1. J9E- 11 & 1.3\%E-11 & $1.3 \%-11$ & $1.39 E-11$ & $1.37 E-11$ & $1.39 E-11$ & $1.34 E-11$ \\
\hline $1 \times 0+20(g)$ & $4.125-09$ & 4. $12 E-09$ & $4.12 x-09$ & $4,12 E-09$ & 4. $12 \varepsilon-09$ & $4.12 x-09$ & $4.12 E-09$ \\
\hline $\cos (g)$ & 1. EOEE -08 & 1. 13ee-08 & 1. $198 E-O B$ & 1. $1 B B E-O B$ & $1,88 E-08$ & 1. B8E-08 & $1.8 B E-08$ \\
\hline $\cos (g)$ & $0.00 E+00$ & $1.00 E-07$ & $5.00 E-07$ & $1.00 E-06$ & $3.00 E-06$ & $1.00 E-05$ & $2.00 E-05$ \\
\hline $\sin (g)$ & $0.00 \varepsilon+\infty$ & $1.76 E=18$ & 7. $81 E-10$ & $1.76 E-17$ & 8. BIE-17 & $1.76 E-16$ & $3,52 E-164$ \\
\hline $\mathrm{H} 3(\mathrm{~g})$ & $5.37 E-015$ & 5. JTE-OS & 5. $37 E-05$ & $5.37 E-05$ & 5. JTE-05 & 9. 3TE-OS & 5. 37E-03 \\
\hline $25(9)$ & 1.07E- 06 & 1.07E -06 & 1.07E-06 & 1.07E-06 & $1.07 E-06$ & $1.07 E-06$ & $1.07 E-06 \%$ \\
\hline
\end{tabular}

B. EPFECSS:OE COMBINED Cd + HaS ON ELECTROLYTR ACTIVITIES

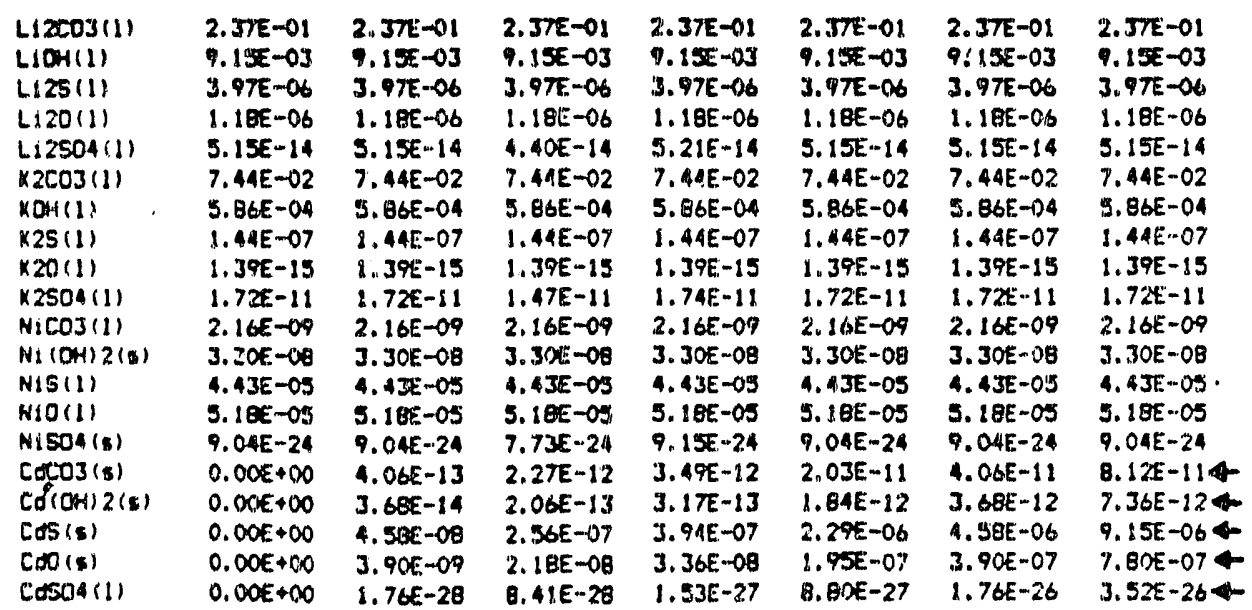

C. EPFECTS ON IONIC CONPOSITION OP THE MELT

\begin{tabular}{|c|c|c|c|c|c|c|c|}
\hline $\begin{array}{l}\mathrm{Wl}+ \\
\mathrm{N}_{+} \\
\mathrm{Ni}_{i+2}\end{array}$ & $\begin{array}{l}6.20 E-01 \\
3.00 E-01 \\
4.41 E-09\end{array}$ & $\begin{array}{l}\text { 1. } 20 E-01 \\
\text { 3. } 90 E-08 \\
4.41 E-09\end{array}$ & $\begin{array}{l}\text { 6. 20E-OI } \\
\text { 3. OOE }-01\end{array}$ & $\begin{array}{l}0.20 E-01 \\
3.00 E-01 \\
4.01 E-04\end{array}$ & $\begin{array}{l}6.20 E-01 \\
3.80 E-01 \\
4.41 E-09\end{array}$ & $\begin{array}{l}6.20 E-01 \\
3.80 E-01 \\
4.41 E-09\end{array}$ & $\begin{array}{l}6.20 E-01 \\
3.00 E-01 \\
4.41 E-09\end{array}$ \\
\hline $\cot 2$ & $0.000+00$ & $7.8 x-13$ & $4.38 x-12$ & $6.74 E-12$ & $3.91 E-11$ & 7. $235-11$ & $1.57 \mathrm{E}-10$ \\
\hline $\cos 3=$ & $9,08 E-01$ & 9. $B O E-01$ & Q. BEE-OI & $9.88 E-01$ & $9.8 B E-01$ & $9.88 E-01$ & $9.88 E-01$ \\
\hline OH- & $1.16 E-02$ & 1. $18 E-02$ & $1.18 E-02$ & 1. 1 BE -02 & $1.18 E-02$ & $1.18 E-02$ & $1.18 E-02$ \\
\hline Se & 4. $485=06$ & $4.455-06$ & $4.45 E-06$ & $4.45 E-06$ & $4.45 x-06$ & $4.455-06$ & $4.45 E-064$ \\
\hline 0:1 & $7.17 E-\infty$ & $7.17 E-08$ & $7,17 E-08$ & $7.17 E-0 B$ & $7.17 E-00$ & $7.1 \pi-08$ & $7.17 \mathrm{E}-\infty$ \\
\hline $504=$ & $1.41 E-11$ & $1.41 E-11$ & $1.206-11$ & $1.43 E-11$ & $1.41 E-11$ & $1.41 E-11$ & $1.41 E-114$ \\
\hline
\end{tabular}

gPEETIES PRESENT AS PUIT: COADERSED PHASES:

Nilcr) yos yes yes yes yes yes yes 
TABLE IV•9

A. GAS SFECIEg PafTIA. PRESSURES IATM;

\begin{tabular}{|c|c|c|c|c|c|c|}
\hline sese: & $\mathrm{Hg}=0$ & $\mathrm{Hg}-\mathrm{I}$ & $H_{g}-2$ & $\mathrm{Hg}-3$ & $\mathrm{Hg}=$ & $\mathrm{Hg}-$ \\
\hline & $6.00 E-02$ & $6.00 E-02$ & $6.00 E-02$ & $6.00 E-02$ & $6.00 E-02$ & $6.00 E-02$ \\
\hline & $1.29 E-23$ & $1.29 E-23$ & $1.29 E-23$ & $1.29 E-23$ & $1.29 E-23$ & $1.29 E-23$ \\
\hline & 3. $01 E-01$ & $3.61 E-01$ & $3.61 E-01$ & $3.61 E-01$ & $3.61 E-01$ & $3.61 E-01$ \\
\hline & $0.00 E+00$ & $1.00 E-06$ & $5.00 E-06$ & 1.00E-05 & $2.00 E-05$ & $3.00 E-05<$ \\
\hline & $2.01 E-01$ & $2.01 E-01$ & 2.01E-01 & $2.01 E-01$ & $2.01 E-01$ & $2.01 E-01$ \\
\hline & $1.79 E-01$ & $1.79 E-01$ & 1. $79 E-01$ & $1.79 t-01$ & $1.79 E-01$ & $1.79 E-01$ \\
\hline & $1.95 E-0.5$ & $1.95 E-05$ & 1. $95 E-05$ & $1.95 t-05$ & $1.95 E-05$ & $1.95 E-05$ \\
\hline & $1.99 E-01$ & $1.99 E-01$ & $1.99 E-01$ & $1.99 E-01$ & $1.99 E-01$ & $1.99 E-01$ \\
\hline & $9.6 \pi E-09$ & $9.62 \varepsilon-09$ & $9.62 E-09$ & $9.62 F-09$ & $9.62 E-09$ & $9.62 E-09$ \\
\hline & 2. $88 E-11$ & 2. $8 B E-11$ & 2. B8E-11 & 2. BAF-11 & $2.88 E-11$ & $2.88 E-11$ \\
\hline & $3.91 E-09$ & $5.91 E-09$ & $5.91 E-09$ & 5. 91E-09 & $5.91 E-09$ & $3.91 E-09$ \\
\hline & $2.36 E-09$ & $2.36 E-09$ & $2.36 E-09$ & $2.36 E-09$ & 2. $37 E-09$ & $2.37 E-09$ \\
\hline & $1.32 E-07$ & $1.32 E-07$ & 1. 32E-07 & $1.32 F-07$ & 1.32E-07 & $1.32 E-07$ \\
\hline & $1.39 E-11$ & 1.39E- 11 & 1. 3\%E-11 & $1.39 E-11$ & 1. $39 E-11$ & $1.39 E-11$ \\
\hline & 4. $12 E-09$ & $4.12 E-129$ & $4.22 E-09$ & $4.22 E-09$ & $4.12 E-09$ & $4.12 E=09$ \\
\hline & $0.00 E+00$ & 4. $03 E-18$ & $2.01 E-17$ & $4.03 E-17$ & 0.06E-17 & $1.21 E-16$ \\
\hline & $0.00 E+O D$ & $4.22 E-19$ & $2.11 E-1 \theta$ & $4.22 E-12$ & B. $44 E-18$ & $1.27 E-17$ \\
\hline & $5.37 \mathrm{E}-0.5$ & 5. 37E-05 & 5. उTE-0.5 & $5.37 t-05$ & $5.37 E-05$ & $5.37 E-05$ \\
\hline
\end{tabular}

B. EFFECTS OF Bg On MOLECULAR ELECTROLYTE SPECIES ACTIVITIES

\begin{tabular}{|c|c|c|c|c|c|c|}
\hline $\operatorname{L12\operatorname {cos}(1)}$ & $2.3 \pi E-01$ & $2.37 E-01$ & 2. $37 E-01$ & 2. J7E-01 & 2.37E-01 & 2. 37E- - \\
\hline $101(1)$ & $9.15 E-0 I$ & $9.15 E-03$ & $9.155-03$ & $9.15 E-03$ & $9.15 E-03$ & $9.15 E-0 J$ \\
\hline $1120(1)$ & 1. 18E-OS & $1.18 E-O 6$ & 1. $18 E-O B$ & $1.18 E-06$ & $1.18 E-06$ & $1.18 E-06$ \\
\hline$k 2 \cos (1)$ & $7.44 E-02$ & $7.44 E-02$ & 7. $44 E-02$ & 7. $44 E-02$ & $7.44 E-02$ & $7.44 E-02$ \\
\hline $\mathrm{KOH}(1)$ & $5.36 E-(1.4$ & $5.8 \Delta E-04$ & S. 8:yE-O4 & 5. $186 E-04$ & $3.86 E-04$ & J.86E-04 \\
\hline$K 20(1)$ & $1.39 E-15$ & 1.39E-15 & $1.39 E-15$ & $1.39 E-15$ & $1.39 E-15$ & 8. $39 E-15$ \\
\hline NiCOz $(1)$ & $2.16 E-117$ & $2.16 E-09$ & $2.16 E-09$ & $2.16 E-09$ & $2.16 E-09$ & $2.16 E-09$ \\
\hline $\mathrm{N} I(\mathrm{OH}) 2(\mathrm{~s})$ & $3.305-08$ & $3.30 E-08$ & 3. $30 E-08$ & ]. J0[-08 & $3.30 E-O B$ & 3.30E-OB \\
\hline $\mathrm{NiO}(1)$ & 5. $16 E-(1)$ & $5.18 E-0 E$ & $5.18 E-05$ & 5. $18 E-0 J$ & 5. $18 E-05$ & $5.18 E-05$ \\
\hline $\mathrm{HgCD}(\mathrm{s})$ & $0.00 E+10$ & $1.23 E-201$ & $6.16 E-20$ & $1.23 E-19$ & $2.46 E-19$ & $3.70 \mathrm{E}-19$ at \\
\hline $\mathrm{Hg}(\mathrm{OH}) 2(5)$ & $0.00 E+00$ & $9.62 E-21$ & $4.81 E-20$ & $9.62 E-20$ & $1.92 E-19$ & $2.89 E-19<$ \\
\hline$A g D(c r)$ & $0.00 E+\infty 0$ & $.34 E-15$ & $71.67 E-14$ & $7.34 E-14$ & $1.17 E-13$ & $2.20 E-13$ \\
\hline
\end{tabular}

\section{EFFECTS ON IONIC COMPOSITION OF THE MELT}

$\begin{array}{lllllll}L 1+ & 0.20 E-01 & 6.20 E-01 & 0.20 E-01 & 6.20 E-01 & 6.20 E-01 & 6.20 E-01 \\ K+ & 3.80 E-01 & 3.80 E-01 & 3.80 E-01 & 3.80 E-01 & 3.80 E-01 & 3.80 E-01 \\ N i+2 & 4.41 E-07 & 4.41 E-09 & 4.41 E-09 & 0.41 E-09 & 4.41 E-09 & 4.41 E-09 \\ H 9+2 & 0.00 E+00 & 2.43 E-201 & 1.21 E-19 & 2.43 E-19 & 4.86 E-19 & 7.28 E-19 \\ E D 3= & 9.83 E-01 & 9.88 E-01 & 9.88 E-01 & 9.08 E-01 & 9.88 E-01 & 9.88 E-01 \\ O H- & 1.13 E-02 & 1.48 E-02 & 1.18 E-02 & 1.18 E-02 & 1.18 E-02 & 1.18 E-02 \\ O= & 7.17 E-08 & 7.17 E-08 & 7.17 E-08 & 7.17 E-08 & 7.17 E-0 B & 7.17 E-0 B\end{array}$

SFECIES PRESENT AS FURE CONDENSEU PHASES:

Wi(cr) yes yes yes yes yes yes 
TABLE IV 10

A. GAS SPECIES FARTIAL PRESSLPES (ATM)

\begin{tabular}{|c|c|c|c|c|c|c|}
\hline Case: & $49-0$ & $\mathrm{Hg}=$ & $\mathrm{Hg}-2$ & $\mathrm{Hg}-$ & $\mathrm{Hg}-$ & $\mathrm{Hg}=\mathrm{s}$ \\
\hline$(8)$ & $6.006-02$ & $6.00 E-02$ & $0.00 E-02$ & $6.00<-02$ & $6.00 E-02$ & $6.00 E-02$ \\
\hline (g) & 1. TAE-23 & $1.29 E-23$ & $1.29 k-23$ & 1.29E-23 & 1.29E-23 & $1.29 E-23$ \\
\hline & $3.61 E-01$ & $3.61 E-01$ & $3.61 E-01$ & $3.61 E-01$ & $3.61 E-01$ & $3.61 E-01$ \\
\hline $2(g)$ & $1.25 x-27$ & 1. 23E-27 & 1.25E-27 & $1.255 t-27$ & $1.25 E-27$ & $1.29 \mathrm{E}-27$ \\
\hline (g) & $0.00 E+\infty 0$ & $1.00 E-06$ & $5.00 E-06$ & $1.00 E-\infty$ & $2.00 E-05$ & $3.00 k-05<$ \\
\hline$(g)$ & $2.01 E-01$ & $2.01 E-01$ & $2.02 E-01$ & $2.01 E-01$ & $2.01 E-01$ & $2.01 E-01$ \\
\hline$O(g)$ & $1.79 \varepsilon-01$ & $1.78 E .01$ & $1.7 \%-01$ & $1.79-01$ & $1.79 E-01$ & $1.79 E-01$ \\
\hline $2012(g)$ & 1. $95-05$ & 1. $95 x-05$ & $1.9 \mathrm{JE}-05$ & 1. $9 \mathrm{EE}$ - -05 & 1.950 .05 & $1.955-09$ \\
\hline$|g|$ & $1.97 E-01$ & $1.99 E-01$ & $1.79 E-01$ & $1.99 E-01$ & 1. $97 E-01$ & $1.99 E-01$ \\
\hline 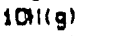 & $9.0 x-07$ & $9.42 E-09$ & $9.62 x=-09$ & $9.62 x-09$ & $9.62 E-\infty 9$ & $9.621=-09$ \\
\hline OH) $2(g)$ & 2. BTE-11 & 2. $87 E-11$ & 2. E7E-11 & 2. $87 E-11$ & 2. $87 E-11$ & $2.8^{\prime} E-11$ \\
\hline $4: 420(9)$ & S. $91 E-09$ & 5. $91 E-09$ & $5.91 E-09$ & $5.91 E \rightarrow 09$ & 5. $91 E-09$ & $3.91 E-09$ \\
\hline$C I(g)$ & 1. $15 E-\infty$ & $1.055=-09$ & $1.055-09$ & $1.055-09$ & 1.05E-09 & $1.05 E-09$ \\
\hline & 2. $35 x-09$ & 2. J35E-C9 & 2. $35 x-09$ & 2. I5T-09 & 2. 35E $-\infty 9$ & 2. $355-09$ \\
\hline$H(g)$ & $1.31 E-07$ & 1.31E -07 & $1.31 E-07$ & $1.31 E-07$ & $1.31 E-07$ & $1.31 E-07$ \\
\hline$(0+1) 2(g)$ & $1.37 E-11$ & $1.37 E-11$ & $1.37 \mathrm{E}-11$ & $1.37 E-11$ & $1.37 E-11$ & $1.37 E-11$ \\
\hline$H 20(g)$ & $4.0 \% E-09$ & $4.09 E-09$ & 4.09E-09 & 4. OPE-09 & $4.09 E-09$ & $4.09 E-09$ \\
\hline$(g)$ & 2. $2 E E-07$ & $2.28:-07$ & 2.7.8E-07 & $2.28 E-07$ & $2.28 E=07$ & 2.28E-07 \\
\hline $1(g)$ & $6.10 E-19$ & $6.10 E-19$ & $6.10 E-19$ & b. $106-19$ & $6.10 E-19$ & $6.10 \varepsilon-19$ \\
\hline $12(g)$ & $2.24 E-29$ & $2.24 E-21$ & $2.24 E-21$ & $2.24 E-21$ & $2.24 E-21$ & $2.24 E-21$ \\
\hline$(g)$ & $0.00 E+\infty 0$ & $4.03 E-18$ & $2.01 E-17$ & $4.03 E-17$ & B. $06 E-17$ & $1.21 E-164$ \\
\hline$l(g)$ & $0.00 E+00$ & $1.46 E-22$ & 7. $31 E-22$ & $1.465 .-21$ & $2.92 E-21$ & $4.39 E-21<$ \\
\hline $12(\mathrm{~g})$ & $0.00 E+00$ & $3.51 E-27$ & 1.75E-2b & $3.51 E-26$ & $7.02 E-26$ & $1.05 E-25$ \\
\hline $\lg 7$ & $0.00 E+(N)$ & 4. 22E -19 & $2.11 E-18$ & $4.2 Z E-1 B$ & 0. 44E-1日 & $1.27 \mathrm{E}-17$ \\
\hline & 5. $37 E-05$ & $5.37 E-05$ & $5.37 \mathrm{E}-0.5$ & $=.3 / 5-05$ & 5. 37E-05 & 5. 37E-0. \\
\hline & $1.01 E-O B$ & $1.01 t-00$ & $1.01 E-09$ & $1.01 E-08$ & $1.01 E-00$ & $1.01 E-08$ \\
\hline
\end{tabular}

B. EFFECTS OP COMBINED Ag + ACI ON ELECTROLYTE ACTIVITIES

\begin{tabular}{|c|c|c|c|c|c|c|}
\hline $\operatorname{Li2r03(1)}$ & 2. 37E-01 & 2.37E-U1 & $2.37 t-01$ & 2. $37=-01$ & 2. 37E-O1 & $2.37 t-01$ \\
\hline $\operatorname{LIOH}(1)$ & $9.15 x-0.3]$ & $9.15 x-03$ & 9. $15 x-03$ & $0.155:-03$ & $9.15 E-03$ & $9.15 E-03$ \\
\hline Letcild) & 3. DTE-OS & $3.07 E-\infty$ & $3.07 E-05$ & $3.07 E-05$ & $3.07 E-05$ & $3.07 E-05$ \\
\hline $\operatorname{li2n}(1)$ & 1. $1 \pi E-06$ & $1.17=-06$ & $1.17 E-06$ & $1.17 \mathrm{E}-06$ & $1.17 E-06$ & $1.17 E-06$ \\
\hline K $2 \cos (1)$ & $7.32 E-02$ & 7. 32E-02 & $7.32 E-02$ & $7.32 F-02$ & 7.J2E-02 & $7.32 E-02$ \\
\hline $\mathrm{KOH}(1)$ & $5.82 E-04$ & $3.82 x-0.9$ & $5.82 E-04$ & 5. $82 f-04$ & $3.02 E-04$ & $5.82 E-04$ \\
\hline $\mathrm{KCl}(1)$ & $9.58 E-03$ & $9.58 E-03$ & $9.58 E-03$ & $9.58 t-03$ & $9.58 E-03$ & $9.58 E-03$ \\
\hline$\times 20(1)$ & $1.37 E-15$ & $1.37 E-15$ & 1. 37E-15 & $1.37 k-15$ & $1.37 E-15$ & $1.37 E-15$ \\
\hline NicoJ (1) & 2. $16 E-09$ & $2.165=-\infty 9$ & 2. $16 E-09$ & 2. $16 E-09$ & $2.16 E-09$ & 2. $16 E-09$ \\
\hline $\mathrm{Hi}(\mathrm{OH}) \mathrm{Z}(\mathrm{s})$ & $3.30 \mathrm{E}-08$ & 3. $306-09$ & 3. $30 E-0 \theta$ & $3.30 E-08$ & 3. 30E-OQ & $3.30 E-08$ \\
\hline Nicla (1) & $2.04 E-19$ & $2.04 E-19$ & $2.04 E-19$ & 2. $04 E-19$ & $2.04 E-19$ & $2.04 E-19$ \\
\hline Nio(l) & 5. 1UE-OS & 9. $18 x-\infty$ & 5. $18 E \cdot 0 \mathrm{OS}$ & 5. $18 E-05$ & $5.10 E-05$ & 5.1BE-OS \\
\hline $\operatorname{HgCOS}(\Phi)$ & $0.00 E+O n$ & 1. $21 E-20$ & $6.04 E-20$ & $1.21 E-19$ & $2.42 E-19$ & $3.63 E-19+$ \\
\hline $\mathrm{Hg}(\mathrm{OH}) \mathrm{Z}(\mathrm{s})$ & $0.00 t: \infty 0$ & 9. 43E-2! & 1. $T 2 E-20$ & $9.43 E-20$ & $1.89 E-19$ & $2.83 E-194-$ \\
\hline $\mathrm{HgCl}(1)$ & $0.00 E+00$ & $4.9 \pi=-24$ & $2.48 E-23$ & $4.97 E-23$ & $9.93 E-23$ & $1.49 E-22<$ \\
\hline Hgo(cr) & $0.000 \div+00$ & $7.20 E-15$ & $3.60 E-11$ & $7.20 E-14$ & $1.44 E-13$ & $2.16 E-13<$ \\
\hline
\end{tabular}

\section{RPFECTS ON IONIC COMPOSITION OP THE RELT}

\begin{tabular}{|c|c|c|c|c|c|c|}
\hline Lit & 6. $20 E-01$ & $6.20<-01$ & $6.20 E-01$ & A. $20 \mathrm{E}-01$ & $6.20 E-01$ & $0.20 E-01$ \\
\hline$k+$ & $3.00 k-01$ & J. BOE-01 & 3. BOE-OI & 3. BOE-01 & $3.00 E-01$ & 3. $80 E-01$ \\
\hline $\mathrm{Ni}+2$ & $4.4 \pi=-\infty$ & 4. $47 E-0.9$ & $4.47 E-09$ & 4. ATE-OA & 4. $4 \pi E-09$ & $4.4 \pi-69$ \\
\hline $\mathrm{Hy}+2$ & D. CEE+C(x) & $2.43 E-20$ & $1.22 E-19$ & 2. 4XE-19 & $4.06 E-19$ & $7.29 E-194$ \\
\hline $\cos$ : & 9. $0 B E-01$ & 9. $8 \Delta E-01$ & 9. DSE - O1 & 9. B.6E-OI & $9.96 E-01$ & 9.06E-01 \\
\hline OH- & 1. IAE $D 0$ & 1. $18 E-02$ & $1.18 E-02$ & 1. $10 E-02$ & 1. $1 \mathrm{EE}-02$ & 1. $18 E-02$ \\
\hline $\mathrm{Cl}-$ & 1. $\operatorname{CeE}-03$ & 1. $80 E-03$ & 1.DE-03 & 1. 8 CEE- 03 & 1. BEE-0J & $1.80 E-034$ \\
\hline $0=$ & 7. $18 E=0 \theta$ & $7.180 \cdot \cos$ & $7.10 E-\infty 8$ & $7.18 E-0 E$ & $7.18 E-00$ & 7. 1EE-09 \\
\hline
\end{tabular}

SFECIES PRESENT aS PURE CONDENSEI PA-ASES:

Niler) yes yes yes yes yes yes 
TABLE IV'11

A. eas species paftial pressures (ATta)

\begin{tabular}{|c|c|c|c|c|c|c|}
\hline Case: & $\mathrm{Hg}-\mathrm{O}$ & $\mathrm{Hg}-1$ & $\mathrm{Hg}-2$ & $\mathrm{Hg}=$ & $\mathrm{Hg}_{\mathrm{g}}-$ & $\mathrm{Hg}-$ \\
\hline (g) & 5. $\% 8 E-02$ & $5.98 E-02$ & 5. $98 \mathrm{BE}-02$ & $5.9 B C-02$ & $5.9 B E-02$ & $5.98 E-02$ \\
\hline (g) & $1.32 E-23$ & $1.32 E-23$ & 1. $x x-23$ & 1.37E-23 & 1. $32 E-23$ & 1. $32 E-23$ \\
\hline 18 & $3.60 E-O 2$ & 3. $60 \mathrm{E}-01$ & ]. $60 E-01$ & 3. $60 E=01$ & $3.60 E-01$ & $3.60 E-01$ \\
\hline $2(g)$ & 1. $2 \pi E-23$ & $1.27 t-23$ & 1.27E-23 & $1.27 \varepsilon-23$ & 1.27E-23 & $1.27 E-23$ \\
\hline (g) & $0.00 E+\infty 0$ & $9.97 E-07$ & 4. $98 E-06$ & $9.97 E-06$ & $1.99 \varepsilon-05$ & $2.99 E-05$ \\
\hline$z(g)$ & $2.02 E-01$ & $2.02 E-01$ & $2.02 E-01$ & 2. $02 E-01$ & $2.02 E-01$ & $2.02 E-01$ \\
\hline $0(g)$ & 1. 0CE $\rightarrow 1$ & $1.00 \mathrm{E}-01$ & 1. BOE-01 & 1. 80 r -01 & $1.80 F-01$ & $1 . B O E-01$ \\
\hline $2012(g)$ & 1. PEE- & 1.98E-os & 1. 7aE-os & 1. $9 B E-05$ & $1.96 E-05$ & 1.98E-0S \\
\hline$|g|$ & 1. $98 E-01$ & $1.9 B E-01$ & 1. 9BE-01 & $1.98 E-01$ & $1.9 B E-01$ & $1.9 B E-01$ \\
\hline $0 i(g)$ & $9.0 \pi E-07$ & $9.07 E-09$ & $9.07 E-09$ & 9. 0'7E-09 & $9.07 E-09$ & $9.07 E-09$ \\
\hline$1 0 4 \longdiv { 2 } ( \mathrm { g } )$ & 2. 5XE-11 & 2. 5SE-11 & 2. $205-11$ & 2. 55E-11 & $2.55 E-11$ & $2.55 E-11$ \\
\hline $0.2120(\mathrm{~g})$ & D. $\triangle O E-09$ & $3.60 E-099$ & 3. $60 E-09$ & $3.60 \%-09$ & 5. $60 E-09$ & 5. 6กE-09 \\
\hline$C l(g)$ & $9.92 E-0 B$ & $9.92 \mathrm{E}-0 . \mathrm{Z}$ & $9.92 E-08$ & $9.92 x-08$ & $9.92 E-08$ & $9.92 E-08$ \\
\hline & 1. $1 \% E-07$ & $1.1 \% \leftarrow 09$ & 1. $19 E-09$ & $1.19 E-09$ & $1.10 E-09$ & $1.19 E-09$ \\
\hline$H(g)$ & b. $6 \pi=-08$ & $6.67 E-O B$ & b. $67 \mathrm{E}-08$ & 6. 67E-0日 & $6.67 E-08$ & $6.67 \mathrm{E}-08$ \\
\hline $\operatorname{all} 2(g)$ & $3.56 E-12$ & 3.56E-12 & 3. $38 E-12$ & $3.56 E-12$ & 3. $56 E-12$ & $3.56 E-12$ \\
\hline $4120(g)$ & 2. $10 E-09$ & $2.10 E-09$ & $2.10 E-09$ & $2.10 E-09$ & $2.10 E-04$ & $2.10 E-09$ \\
\hline$(g)$ & 1. $1 \pi E-\infty 5$ & 1. $17 \mathrm{E}-0^{*}$ & $1.27 E-\infty 3$ & 1.17E-0s & $1.17 t-05$ & 1.17E-OS \\
\hline $1 \quad(g)$ & 6. $15 E-17$ & 6. $15 E-17$ & b. $15 E-17$ & b. $15[-17$ & $6.15 E-17$ & $6.15 E-17$ \\
\hline $12(g)$ & 2. $2 \mathrm{EE}-17$ & $2.28 E-17$ & $2.28 E-17$ & $2.28 E-17$ & 2. $2 B E-17$ & $2.28 E-17$ \\
\hline & $0.00 E+00$ & $0.01 E-18$ & $2.00 E-17$ & $4.01 E-17$ & $0.02 E-17$ & $1.20 E-16$ \\
\hline & $0.0 \times E+(\infty)$ & $1.47 E-201$ & 7. J5E-20 & 1. ATE-19 & $2.94 E-19$ & $4.41 E-19$ \\
\hline 1280 & $0.00 E \$ O 0$ & $3.56 E-23$ & 1. $7 B E-22$ & $3.565-22$ & $7.12 E-22$ & $1.07 E-21$ \\
\hline & $0.00 E+10$ & $4.24 E-19$ & $2.12 E-18$ & $4.24 E-18$ & B. $48 E-18$ & $1.27 E-17$ \\
\hline & 5. 3AE-CL & $5.34 E-C 5$ & 5. 34E-05 & 5.34E-O5 & $5.34 E-05$ & $5.34 E-05$ \\
\hline$(g)$ & $1.02 z-06$ & $1.02 E-06$ & $1.02 E-06$ & $1.02 E-06$ & $1.0 x=-06$ & $1.02 E-06$ \\
\hline
\end{tabular}

B. EFFECTS OF COMBINED Bg + HCl ON ELECTROLYTE ACTIVITIES

\begin{tabular}{|c|c|c|c|c|c|c|}
\hline $\begin{array}{l}\text { LizCDa (1) } \\
\text { LiOH(1) } \\
\text { Lici(1) }\end{array}$ & $\begin{array}{l}2.11 E-01 \\
0.62 E=03 \\
2.90 E-03\end{array}$ & $\begin{array}{l}2.11 E-01 \\
8.62 E-03 \\
2.90 E-03\end{array}$ & $\begin{array}{l}2.11 E-01 \\
0.62 E-03 \\
2.90 E-03\end{array}$ & $\begin{array}{l}2.11 E-01 \\
0.62 E-03 \\
2.90 E-03\end{array}$ & $\begin{array}{l}2.11 E-01 \\
0.62 E-03 \\
2.90 E-03\end{array}$ & $\begin{array}{l}2.11 E-01 \\
0.62 E-03 \\
2.90 E-03\end{array}$ \\
\hline $\operatorname{Li20}(1)$ & $1.04 E-06$ & $1.04 E-06$ & $1.04 E-06$ & 1. CAE-O6 & $1.04 E-06$ & $1.04 E-06$ \\
\hline$x 2 \cos (1)$ & $1.91 \mathrm{E}-02$ & $1.91 E-02$ & $1.91 E-02$ & 1.9:E-02 & $1.91 E-02$ & $1.91 E-02$ \\
\hline $\mathrm{xOH}(1)$ & $2.9 \pi[-0.9$ & $2.97 E-04$ & $2.97 E-04$ & 2. 97E-04 & $2.97 E-04$ & $2.97 E-04$ \\
\hline $\mathrm{KCl}(1)$ & $4.90 E-01$ & $4.90 E-01$ & $4.90 E-01$ & $4.90 E-01$ & $4.90 E-01$ & $4.90 E-01$ \\
\hline$\times 20(1)$ & 3. 54E-16 & 3. JSE-16 & 3. $=5 E-16$ & $3.5 \times[-16$ & 3. SEE-16 & 3. $5 E E-16$ \\
\hline Nicos $(1)$ & 2. $20 E-0 ?$ & 2.19E-OQ & $2.19 \mathrm{E}-09$ & 2. $19 E-09$ & $2.19 E-09$ & 2. $19 E-09$ \\
\hline $\mathrm{N} /(\mathrm{OH}) 2(\mathrm{~s})$ & 3. $359-08$ & 3. JSE-OB & ] IEE-08 & 3. JEE $-O B$ & J. J5E-00 & 3. 35E-0G \\
\hline Nicle (d) & $2.00 E-15$ & 2. OAE-1E & 2. COE-15 & $2 . \cos E-10$ & $2.0 B E-15$ & $2.0 \mathrm{E}-13$ \\
\hline N1O(l) & 5. 3.2E-05 & $3.22 E-0 \%$ & $5.22 \mathrm{E}-05$ & $5.22 E-05$ & $5.22 E-05$ & $5,22 \mathrm{E}-0 \mathrm{~S}$ \\
\hline $\operatorname{HgCO} 3(5)$ & $0.00 E+\infty 0$ & $2.44 E-21$ & $1.2 \angle E-20$ & $2.44 E-20$ & 4. BQE-2O & $7.3 i E-20$ \\
\hline$g(D+1) 2(x)$ & $0.00 E+(100$ & $1.91 E-21$ & 9. $D E-21$ & $1.91 E-20$ & 3. $81 E-20$ & \\
\hline Col2(1) & $0.00 E 4, \mathrm{~J}$ & $1.01 E-2 \pi 1$ & 3. 0.JE-20 & $1.01 E-19$ & $2.01 E-19$ & $3.02 \mathrm{E}$ \\
\hline HgO(cr) & $0.00 \mathrm{E}+0 \mathrm{cu}$ & $1.45 E-15$ & $7.23 E-15$ & 1.45[-14 & 2.89E-14 & $4.34 E-14$ \\
\hline
\end{tabular}

C. RPPECTS ON IONIC COMPOSITION OF THE MELT

\begin{tabular}{|c|c|c|c|c|c|c|}
\hline LIt & $6.20 E-01$ & $6.20 E-01$ & 6. 20E-01 & b. $20<-01$ & $6.20 E-01$ & $0.20 E-01$ \\
\hline$x+$ & $3.605-01$ & 3. BaE - 01 & 3. $0 E-01$ & 3. $80 E-01$ & 3. $B O E-01$ & $3.80 E-01$ \\
\hline$N: 42$ & $1.45 \dot{E}-00$ & $1.44 E-09$ & $1.44 E-08$ & 1. $44 E-09$ & 1. $\triangle A E-O B$ & $1.44 E-09$ \\
\hline $\mathrm{Hag}+2$ & $0.00 E+00$ & 2. $64 E--201$ & 1. I2E-19 & $2.64 E-19$ & $5.28 E-19$ & $7.93 E-19$ \\
\hline $\cos _{3}=$ & 1. $365-01$ & $8.36 E-01$ & 8. 36E-01 & $0.36 E-01$ & B. 36E -01 & B. $36 E-01$ \\
\hline ot. & $1.26 E-02$ & $1.26 E-02$ & $1.26=-02$ & $1.26 E-02$ & $1.26 E-02$ & $1.26 E-02$ \\
\hline Cl- & $1.51 E-01$ & $1.51 E-01$ & $1.51 E-01$ & $1.51 E-01$ & $1.51 E-01$ & $1.51 E-01$ \\
\hline $0=0$ & e. $00 x-98$ & $0.90 E-09$ & $0.90 E-08$ & B. .OE-OE & $0.90 E-08$ & $0.905-08$ \\
\hline
\end{tabular}

SFECIES PRESENT AS PURE COOCENSEI PMASES:

NI(R) yes yey yos yes yes yes 
TABLE IV*12

A. BAG SFECIES PARTIAL PRESSURES (ATM)

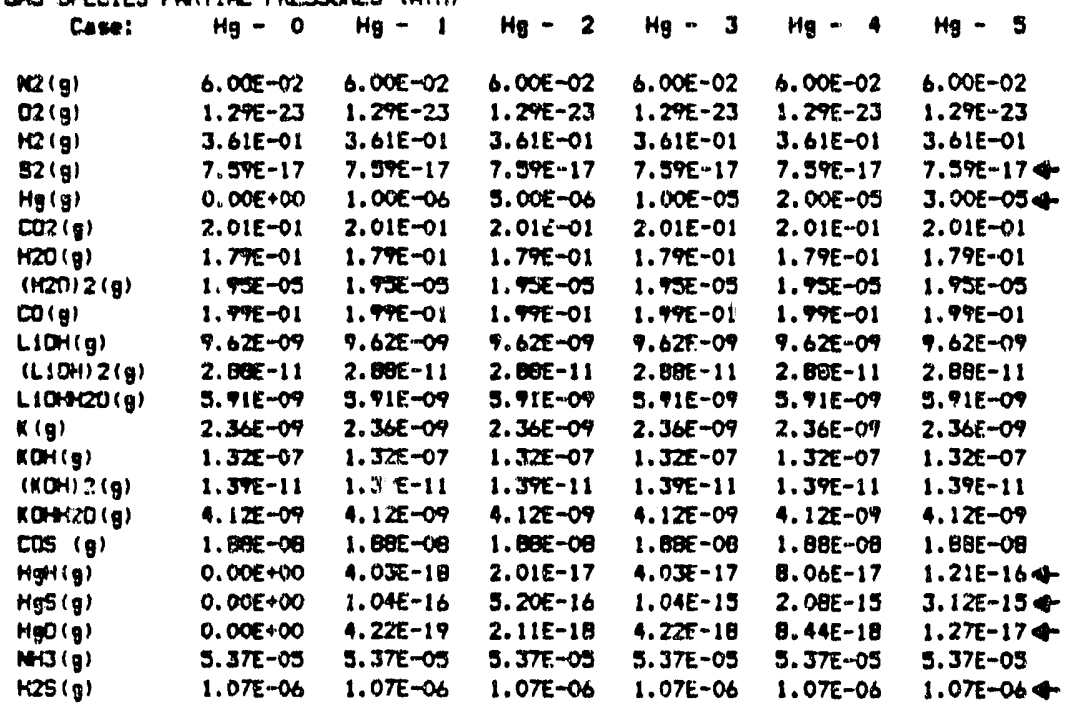

B. EFFECTS OF COMPBINED Bg + B2S ON RLECTROLYTE ACTIVITIES

\begin{tabular}{|c|c|c|c|c|c|c|}
\hline $\begin{array}{l}\operatorname{li2} \cos (1) \\
\operatorname{L10}(111) \\
\operatorname{l128}(1)\end{array}$ & $\begin{array}{l}2.37 E-01 \\
9.15 E-03 \\
3.97 E-06\end{array}$ & $\begin{array}{l}2.37 \mathrm{E}-01 \\
9.15 \mathrm{E}-03 \\
3.97 \mathrm{E}-06\end{array}$ & $\begin{array}{l}2.37 E-01 \\
9.15 E-03\end{array}$ & $\begin{array}{l}2.37 E-01 \\
9.15 E-03\end{array}$ & $\begin{array}{l}\text { 2. } 37 E-01 \\
9.15 E-03\end{array}$ & $\begin{array}{l}\text { 2. } 37 \mathrm{E}-01 \\
9.15 \mathrm{E}-03\end{array}$ \\
\hline$L 120(1)$ & $1.10 E-06$ & 1. 1BE - & $1.18 E-06$ & $1.1 B E-0.6$ & 1. $18 E-O 6$ & $\begin{array}{l}3.77 E-06 \\
1.18 E-66\end{array}$ \\
\hline LIZSO4 (1) & $=15 E-14$ & $3.15 E-19$ & 5. $15 E-14$ & $5.15 E-14$ & 5. $15 E-14$ & $9.15 E-24$ \\
\hline$\times 2 \cos (1)$ & 7. $44 E-0 \%$ & $7.44 E-02$ & 7. 4AE -02 & $7.44 E-02$ & $7.44 E-02$. & $7.41 E-02$ \\
\hline $\mathrm{KOH}(1)$ & J. BSE-04 & $5.86 E \bigcirc 4$ & 5. QSE -04 & 5. $86 E-0$. & 5. B6E-OA & $5.86 E-04$ \\
\hline$\times 25(1)$ & $1.44 E-07$ & $1.44 E-07$ & $1.44 E-07$ & $1.44 E-07$ & $1.44 E-07$ & 1. 44E -07 \\
\hline$\times 20(1)$ & 1.3YE-15 & 1.J9E-1E & $1.39 E-15$ & $1.39 E-15$ & 1. $39 E-15$ & $1.39 E-15$ \\
\hline$k 2504(1)$ & $1.72 E-18$ & $1.72 E-11$ & $1.72 E-11$ & $1.72 E-11$ & 1.72E-11 & $1.72 E-11$ \\
\hline $\operatorname{Nicos}(1)$ & $2.165-09$ & $2.16 E-09$ & 2. $16 E-09$ & 2. $16 E-09$ & $2.16 E-09$ & $2.16 E-\infty 9$ \\
\hline N1 $(O H) 2(8)$ & 3. $3 C E-0 \theta$ & $3.30 E-\infty 8$ & 3.30E -00 & 3. $30 E-00$ & 3. $30 E-O B$ & $3.30 E-08$ \\
\hline Nis(1) & $4.43 E-05$ & 4. 43E-0. & 4.4JE -05 & $4.4 \pi-05$ & $4.43 E-05$ & $4.43 E-05$ \\
\hline NiD(1) & $3.18 E-05$ & $3.18 E-\infty)$ & $5.18 E-O S$ & $3.10 E-05$ & 5. 18E- -05 & $3.18 E-05$ \\
\hline N1SOA (\$) & $9.14 E-24$ & $9.04 E-24$ & $9.04 E-24$ & $9.04 E-24$ & 9. OAE-24 & $9.04 E-24$ \\
\hline $\mathrm{HgCO} 3(5)$ & $0 . \cos +\infty)$ & $9.70 E-16$ & 4. $\cos -15$ & $9.70 E-15$ & $1.94 E-14$ & $2.91 E-14<$ \\
\hline $\mathrm{Hg}(\mathrm{OH}) 2(5)$ & $0.0 \times 5+\infty 00$ & $7.57 E-16$ & 3. $78 E-13$ & 7.5TE-15 & 1. 31E-14 & $2.27 E-140$ \\
\hline HgS(d) & 0. COEACAD & $4.55 E-05$ & 2. $28 E-04$ & $4.55 x-04$ & $9.105-09$ & 1.37E-03 \\
\hline $\mathrm{HgO}(\mathrm{er})$ & 0. COSE +00 & $9.78 E-10$ & 2. $89 E-09$ & 5.78E- -99 & $1.16 E-O B$ & $1.73 E-08$ \\
\hline $\mathrm{HgSO}(1)$ & 0. CNAE $+\infty 0$ & $3.94 E-72$ & $1.97 \mathrm{E}-31$ & $3.94 E-31$ & 7. ET/E-31 & $1.18 E-304$ \\
\hline
\end{tabular}

C. EFPECTS ON IONIC COMPOSITION OF THE MELT

\begin{tabular}{|c|c|c|c|c|c|c|}
\hline Lit & 6. $20 E-01$ & $6,20 E-01$ & $0.20 E-01$ & $6.20 E-01$ & $6.20 E-01$ & $6.20 \varepsilon-01$ \\
\hline$k+$ & $3.806-02$ & 3. $80 x-01$ & 3. $00 E-01$ & 3. $80 x-01$ & 3. 00E -01 & $3.60 E-01$ \\
\hline$N ! \geqslant 2$ & $4.41 E-09$ & $4.4115-09$ & 4.4:E-09 & 4. AIE-OQ & 4. A1E-0.9 & $4.41 E-09$ \\
\hline $\mathrm{Hg}+2$ & $0.00 E+00$ & $1.91 E-1 E$ & $9.565-15$ & $1.91 E-14$ & $3.825-14$ & $5.73 E-14<$ \\
\hline $\cos =$ & 9. $\operatorname{BeE}-01$ & 9. $89 x-01$ & $9.00 E-01$ & 9. Bac-01 & 9. $680-01$ & 9. $80 E-01$ \\
\hline $\mathrm{OH}$ & 1. $18 \div-02$ & $1.108-02$ & 1. $18 E-02$ & 1. $10 x-02$ & 1. $18 E-02$ & $1.18 E-02$ \\
\hline $9=$ & $4.45 x-06$ & $4.45 E .06$ & $1.45 x-06$ & $4.455-06$ & $4.45 E-06$ & $4.45 E-06 t$ \\
\hline $0=$ & $7,1 \pi-\infty$ & $7.17 t-00$ & $7.17 \mathrm{E}-\infty$ & $7.17 E-09$ & 7. $17 \pi-00$ & $7.17 E-08$ \\
\hline $\operatorname{sos} x$ & $1.41 E-11$ & $1.41 E-11$ & $1.41 E-11$ & $1.41 E-11$ & 1. A1E-11 & $1.41 E-11=$ \\
\hline
\end{tabular}

SFECIES PRESENT AS PLWE CONDENEED PHasEs:

Niler) yes yes yes yos yes yes 


\section{APPENDIX B}

FREE ENERGIES OF FORMATION OF CONTAMINANTS \& PRODUCTS

Standard Free Energies of Formation $(\Delta G)$ for $A l 1$ the Gaseous, Liquid, and Solid Species that were used in the SOLGASMIX Computations are provided as:

- Free Energies in $\mathrm{kJ} / \mathrm{mol}$

- Temperatures from 900 to 1000 degree Kelvin

- Referenced to $\varnothing \mathrm{kJ} / \mathrm{mol}$ for the pure element at the given temperature of calculation 
GAS PHASE SPECIES OF TRACE CONTAMINANTS AND FUEL CELL INTERACTION COMPOUNDS

\begin{tabular}{|c|c|c|c|c|c|}
\hline TEMFEFATURE: & $\$ 000.0 \mathrm{~K}$ & $\$ 23.11 \mathrm{~K}$ & $950.0 \mathrm{~K}$ & $975.0 \mathrm{~K}$ & $1000.0 \mathrm{~K}$ \\
\hline$A \tilde{S}(g)$ & 179.57 & 177.46 & 174.75 & 172.64 & 170.32 \\
\hline$A \leq 2(g)$ & 46.39 & 44.77 & 42. 87 & 41.10 & 39.34 \\
\hline$A s 3(g)$ & 86.59 & 85.11 & 83.38 & 81.77 & 80.16 \\
\hline As4 (g) & 0.00 & 0.00 & 0.00 & 0.00 & 0.00 \\
\hline$A=C 13(g)$ & -231.22 & -227.30 & -227.05 & -224.97 & -222.88 \\
\hline AsH3is $g$ ! & 83.73 & 85.36 & 87.27 & 89.04 & 90.82 \\
\hline$A=S(g)$ & 67.64 & 66.91 & 65.99 & 65.14 & 64.30 \\
\hline AsSe $(g)$ & 60.93 & 60.05 & 59.03 & 58.08 & 57.13 \\
\hline$C O(g)$ & -191.42 & -193.45 & -195.85 & -198.06 & -200.28 \\
\hline $\operatorname{coz}(g)$ & $-395,75$ & -395.78 & -395.82 & -395.85 & -395.89 \\
\hline cos ( 3 ' & $-z 11.5 z$ & -211.76 & -212.03 & $-212.2 \%$ & -212.54 \\
\hline $\operatorname{cs}(y)$ & :33.99 & 131.30 & 129.36 & 127.10 & 124.84 \\
\hline CS2 (S) & -16.60 & -10.76 & -16.95 & -17.13 & $-17.3 !$ \\
\hline $\operatorname{cog}(g)$ & 13.20 & 11.03 & 8. 49 & 6.11 & 3.75 \\
\hline $\csc 12(3)$ & -219.90 & -218.97 & -219.05 & -219.12 & -219.19 \\
\hline $\cos (3)$ & 60.01 & 58.64 & 57.03 & 55.54 & 34.04 \\
\hline $\operatorname{Cose}(3)$ & 89.76 & 88.41 & 86.83 & 85.37 & 83.91 \\
\hline $\operatorname{c.12}(3)$ & 0.00 & 0.50 & 0.00 & 0.00 & 0.00 \\
\hline $\mathrm{H} 2(g)$ & 0.00 & 0.510 & 0.00 & 0.00 & 0.00 \\
\hline$H C](3)$ & -100.15 & -100.30 & -100.47 & -100.64 & -100.80 \\
\hline$H 2 O(3)$ & -178.00 & -176.32 & -175.34 & -193.96 & -192.59 \\
\hline$(\mathrm{H} 2 \mathrm{O}) 2(\mathrm{~g})$ & -341.10 & -3ב. 37 & -331.80 & -327.11 & -322.42 \\
\hline$H 25$ (9) & $-45.9 ?$ & -4.4 .75 & -43.43 & -42.21 & -40.98 \\
\hline H2SE ( 3 ) & -3.33 & -2.24 & -0.95 & 0.25 & 1.44 \\
\hline $\mathrm{H}_{3}(\mathrm{~g})$ & 0.00 & 0.00 & 0.00 & 0.00 & 0.00 \\
\hline HaCI ( 3$)$ & 41.48 & 42.13 & 42.89 & 43.59 & 44.29 \\
\hline $\mathrm{H}_{3} \mathrm{C} ! 2(\mathrm{~g})$ & -116.21 & -113.93 & -111.26 & -108.79 & -105.31 \\
\hline $\mathrm{HgH}(3)$ & 196.91 & 197.44 & 198.07 & 198.64 & 199.22 \\
\hline $\mathrm{HgO}(\mathrm{g})$ & 15.53 & 16.44 & 17.52 & 18.51 & 19.50 \\
\hline $\mathrm{HgS}(3)$ & 33.13 & 33.98 & 34.97 & 35.89 & 36.82 \\
\hline HgSe (g) & 67.76 & 68.93 & 69.85 & 70.80 & 71.74 \\
\hline$K(g)$ & 10.77 & 8.99 & 6.90 & 4.97 & 3.03 \\
\hline$k 2(3)$ & 32.35 & 30.51 & 28.35 & 26.34 & 24.34 \\
\hline$K C](3)$ & -262.05 & -263.93 & -264.99 & -266.07 & -267.14 \\
\hline$K O H(g)$ & -228.31 & -229.10 & -227.63 & -227.29 & -226.94 \\
\hline$(k \square+1) 2(g)$ & -511.47 & -507.29 & -502.37 & -497.83 & -493.28 \\
\hline $\mathrm{KOHH} \angle O(g)$ & -415.93 & -411.44 & -406.14 & -401.23 & -376.33 \\
\hline $\operatorname{Li}(g)$ & $66.3 \%$ & 64.16 & 61.61 & 59.26 & 56.90 \\
\hline
\end{tabular}


GAS PHASE SPECIES (continued)

\begin{tabular}{|c|c|c|c|c|c|}
\hline TEMFERATURE: & $900.0 \mathrm{~K}$ & $923.0 \mathrm{~K}$ & $950.0 \mathrm{~K}$ & $975.0 \mathrm{~K}$ & $1000.0 \mathrm{~K}$ \\
\hline Li2 $(g)$ & 104.17 & 101.80 & 99.01 & 96.43 & 93.84 \\
\hline $\operatorname{LiCl}(g)$ & -253.80 & -254.90 & -256.34 & -257.67 & -259.00 \\
\hline Li2C:12(g) & -593.89 & -593.33 & -592.73 & -592.17 & -591.62 \\
\hline $\operatorname{LiJC13(g)}$ & -909.01 & -906.63 & -903.12 & -899.88 & -896.64 \\
\hline $\operatorname{LiOH}(g)$ & $-240.3 ?$ & $-240 . .34$ & -240.27 & -240.21 & -240.15 \\
\hline$(L I O H) 2(g)$ & -581.59 & -577.72 & -573.17 & -568.96 & -564.74 \\
\hline LIOHH2O(g) & -450.99 & -446.63 & -441.52 & -436.78 & -432.04 \\
\hline $\mathrm{N} 2(\mathrm{~g})$ & 0.00 & 0.100 & 0.00 & 0.00 & 0.00 \\
\hline $\mathrm{NH} 3(\mathrm{~g})$ & 50.25 & 52.93 & 56.08 & 59.99 & 61.91 \\
\hline $\mathrm{NiCl}(g)$ & 86.45 & 84.17 & 81.51 & 79.04 & 76.57 \\
\hline NiCla $(g)$ & -109.63 & -110.48 & -111.47 & -112.38 & -113.30 \\
\hline $02(g)$ & 0.00 & 0.130 & 0.00 & 0.00 & 0.00 \\
\hline$P D(g)$ & 100.98 & 96.83 & 96.31 & 93.97 & 91.64 \\
\hline$P b 2(g)$ & 208.17 & 205.59 & 202.54 & 199.72 & 196.89 \\
\hline $\mathrm{POCl}(g)$ & -53.96 & -55.43 & -57.16 & -58.76 & -60.37 \\
\hline Focla $(g)$ & -195.26 & -195.54 & -195.87 & -196.18 & -196.48 \\
\hline $\mathrm{PbCl} 14(\mathrm{~g})$ & $-347.8 ?$ & -341.65 & -334.41 & -327.70 & -320.99 \\
\hline $\mathrm{FbH}(\mathrm{g})$ & 161.65 & 160.06 & 158.19 & 156.45 & 154.72 \\
\hline POO(g) & 10.84 & 7.20 & 8.15 & 6.81 & 5.46 \\
\hline $\operatorname{FbS}(g)$ & 8.22 & 6.99 & 5.56 & 4.23 & 2.90 \\
\hline Fose (g) & -2.70 & -4.102 & -5.58 & -7.02 & -8.46 \\
\hline $52(g)$ & 0.00 & 0.100 & 0.00 & 0.00 & 0.00 \\
\hline $\mathrm{Se} 2(\mathrm{~g})$ & 0.00 & 0.100 & 0.00 & 0.00 & 0.00 \\
\hline $\sec 12(g)$ & -56.513 & -55.39 & -54.00 & -52.71 & -51.43 \\
\hline $5 e 2 C 12(g)$ & -56.7 .7 & -54.16 & -51.13 & -48.33 & $-45 ., 53$ \\
\hline $\operatorname{SeO}(g)$ & -12.75 & -12.86 & -13.00 & -13.12 & -13.24 \\
\hline $5 e 02(g)$ & $-118.5 ?$ & -117.00 & -115.21 & -113.55 & -111.89 \\
\hline $\operatorname{Sn}(g)$ & 205.10 & 202.58 & 199.84 & 197.22 & 194.59 \\
\hline $5 n C 12(g)$ & -214.67 & -214.40 & -214.12 & -213.85 & -213.59 \\
\hline $\operatorname{SnCl} 14(g)$ & -367.75 & -364.58 & -360.86 & -3.57 .41 & -353.97 \\
\hline $\mathrm{SnH} 4(\mathrm{~g})$ & 253.07 & 255.83 & 259.07 & 262.07 & 265.07 \\
\hline $\operatorname{SnO}(g)$ & -40.05 & -41.27 & -42.70 & -44.01 & -45.33 \\
\hline $\operatorname{sns}(g)$ & -19.01 & -20.19 & -21.57 & -22.85 & -24.13 \\
\hline SnSe (g) & -17.08 & -18.45 & -20.05 & -21.54 & -23.02 \\
\hline $\operatorname{Zn}(g)$ & $27.7 t$ & 25.46 & 22.76 & 20.26 & 17.76 \\
\hline$Z \cap C 12(g)$ & -271.32 & -271.16 & -270.98 & -270.81 & -270.64 \\
\hline $\operatorname{InS}(g)$ & 60.31 & 58.68 & 56.78 & 55.01 & 53.24 \\
\hline Inse $(g)$ & 98.46 & 97.08 & 95.46 & 93.96 & 92.46 \\
\hline
\end{tabular}



AND CARBONATE MELT INTERACTION COMPOUNDS

\begin{tabular}{|c|c|c|c|c|c|}
\hline TEMFERATURE: & $900.0 \mathrm{~K}$ & $923.0 \mathrm{~K}$ & $950.0 \mathrm{~K}$ & $975.0 \mathrm{~K}$ & $1000.0 \mathrm{~K}$ \\
\hline$A 5252(1)$ & -126.43 & -121.86 & -116.50 & -111.53 & -106.57 \\
\hline As:253(1) & -161.76 & $-15 \dot{b} .41$ & -150.55 & -144.95 & -139.35 \\
\hline As: $25 e 3(1)$ & -118.52 & -113.71 & -108.05 & -102.82 & -97.58 \\
\hline $\operatorname{cod}(1)$ & 0.00 & 0.100 & 0.00 & 0.00 & 0.00 \\
\hline $\operatorname{Cd} 3 A s 2(1)$ & $1.6 A$ & 2.105 & 2. 25 & 2.44 & 2.62 \\
\hline $\operatorname{cdc} 12(1)$ & -254.51 & -252.101 & -249.07 & -246.35 & -243.63 \\
\hline $\operatorname{cds04}(1)$ & -583.53 & -573.55 & -561.84 & -550.99 & -540.14 \\
\hline $\operatorname{CdSe03(1)}$ & -321.55 & -314.71 & -306.67 & -299.23 & -291.79 \\
\hline $\mathrm{HgCl}(\hat{2}(1)$ & -82.357 & $-7 E .1 B$ & -73.29 & -68.76 & -64.23 \\
\hline $\mathrm{HgS}(1)$ & 2.43 & 6.37 & 10.99 & 15.26 & 19.54 \\
\hline $\mathrm{HgSO}_{4}(1)$ & -.335 .99 & -324.32 & -310.61 & -297.91 & -285.22 \\
\hline$K(1)$ & 0.00 & $0 . n 0$ & 0.00 & 0.00 & 0.00 \\
\hline$k \cdot 2 \cos (1)$ & -983.12 & -877.24 & -870.33 & -86.3 .93 & -857.54 \\
\hline$K C I(1)$ & -.347 .07 & -345.52 & -343.69 & -342.00 & -340.32 \\
\hline$k 20(1)$ & -228.77 & -226.58 & -224.01 & -221.63 & -219.25 \\
\hline $\mathrm{KOH}(1)$ & -295.16 & -292.46 & -289.29 & -286.35 & -283.42 \\
\hline$k 25(1)$ & $-310.7 ?$ & -302.41 & -305.41 & -302.63 & -299.85 \\
\hline$k 2504(1)$ & -1057.80 & -1048.100 & -1036.50 & -1025.80 & -1015.10 \\
\hline$L i(1)$ & 0.00 & 0.00 & 0.00 & 0.00 & 0.00 \\
\hline $\operatorname{Li} 2 \operatorname{CO} 3(1)$ & -956.22 & -950.99 & -944.85 & -939.16 & -933.47 \\
\hline $\operatorname{LiCl}(1)$ & -335.10 & -333.91 & -332.30 & -330.91 & -329.51 \\
\hline Li $20(1)$ & -451.77 & -449.18 & -446.16 & -443.37 & -440.58 \\
\hline $\mathrm{LiOH}(1)$ & -348.80 & -345.98 & -342.65 & -339.58 & -336.51 \\
\hline $\operatorname{Li} 2 S(1)$ & $-401.1 d$ & -398.71 & -395.80 & -393.11 & -390.41 \\
\hline Li2S04 (1) & -1077.70 & -1066.20 & -1057.10 & -1046.90 & -1036.50 \\
\hline $\mathrm{NiCO}(1)$ & -462.70 & $-45 \% .19$ & -450.72 & -444.73 & -438.73 \\
\hline $\mathrm{NiCl}$ (I) & -147.10 & -145.13 & -142.80 & -140.65 & -138.50 \\
\hline $\mathrm{NiO}(1)$ & -127.94 & -126.49 & -124.79 & -123.21 & -121.63 \\
\hline $\mathrm{NiS}(1)$ & -66.73 & -65.50 & -64.05 & -62.71 & -61.36 \\
\hline NiS? (1) & -77.04 & -74.21 & -70.88 & -67.79 & -64.71 \\
\hline NiJS2 (1) & -184.24 & -182.37 & -180.17 & -178.14 & -176.10 \\
\hline Fo (1) & 0.00 & 0.100 & 0.00 & 0.00 & 0.00 \\
\hline $\mathrm{PbCl} 2(1)$ & -231.13 & -228.77 & -225.94 & -223.32 & -220.70 \\
\hline$F b D(1)$ & -123.63 & -121.98 & -119.76 & -117.80 & -115.84 \\
\hline Pbs (1) & -77.90 & -76.109 & -73.96 & -71.99 & -70.01 \\
\hline $\mathrm{FbSe}(1)$ & $-74,45$ & -73.19 & -71.70 & -70.33 & -68.95 \\
\hline Se(i) & -4.46 & -3.14 & -1.59 & -0.15 & 1.28 \\
\hline $\operatorname{sn}(1)$ & 0.00 & 0.170 & 0.00 & 0.00 & 0.00 \\
\hline $\mathrm{SrCl}(2)$ & -216.94 & -214.58 & -211.82 & -209.26 & -206.71 \\
\hline $\operatorname{SrCl}+(1)$ & -334.81 & -330.74 & -325.96 & -321.54 & -317.11 \\
\hline Sr:O(1) & -185.33 & -183.34 & -181.00 & -178.84 & -176.67 \\
\hline $5 \pi 02(1)$ & -370.14 & -356. 06 & -361.27 & -356.84 & -352.41 \\
\hline Sris $(1)$ & -83.86 & $-8: .30$ & -80.45 & -78.75 & -77.04 \\
\hline SnSe(1) & $-84.8 !$ & -83.58 & -82.13 & -80.79 & -79.45 \\
\hline $2 \pi(1)$ & 0.00 & 0.000 & 0.00 & 0.00 & 0.00 \\
\hline $2 n 3452(1)$ & $-53.7 !$ & -53.29 & -52.80 & -52.34 & -51.89 \\
\hline $2 r: 012(1)$ & -284.001 & -281.07 & -277.62 & -274.43 & -271.24 \\
\hline $2 n 0(1)$ & -245.53 & -243.26 & -240.61 & -238.14 & -235.68 \\
\hline $\ln 5(1)$ & -160.21 & -158.27 & -155.99 & -153.88 & -151.77 \\
\hline $\ln E \in 03(1)$ & -385.683 & -378.55 & -369.95 & -361.99 & -354.01 \\
\hline
\end{tabular}


SOLID PHASE SPECIES OF TRACE CONTAMINANTS AND FUEL CELL INTERACTION COMPOUNDS

\begin{tabular}{|c|c|c|c|c|c|}
\hline TEMFERATUKE: & $900.0 x$ & $923.0 \mathrm{~K}$ & $950.0 \mathrm{~K}$ & $975.0 \mathrm{~K}$ & $1000.0 \mathrm{~K}$ \\
\hline$c(e r)$ & 0.00 & 0.50 & 0.00 & 0.00 & 0.00 \\
\hline $\operatorname{Cd} 3 A 52(5)$ & -9.71 & -6.70 & -3.17 & 0.10 & 3.36 \\
\hline $\operatorname{cocos}(5)$ & -509.81 & -504.010 & -497.18 & -490.86 & -484.54 \\
\hline$C 00(5)$ & -168.68 & -166.30 & -163.51 & -160.92 & -158.33 \\
\hline $\mathrm{Cd}(\mathrm{OH}) 2(\mathrm{~s})$ & -294.28 & -287.54 & -279.64 & -272.31 & -264.99 \\
\hline $\operatorname{cds}(5)$ & -127.59 & -125.30 & -122.02 & -120.43 & -118.04 \\
\hline $\operatorname{cds} 04(5)$ & -589.41 & -579.116 & -566.92 & -555.68 & -544.43 \\
\hline CASE $(5)$ & -128.95 & -126.57 & $-123.8 \mathrm{e}$ & -121.40 & -118.92 \\
\hline Cdsegz!s) & -324.79 & -316.46 & -306.60 & -257.63 & -288.57 \\
\hline $\mathrm{H}_{3} \mathrm{CO}(\mathrm{s})$ & -280.22 & -272.94 & -264.41 & -256.50 & -248.60 \\
\hline $\mathrm{H}_{3} \mathrm{Cl} 2 \mathrm{Cr}$ ) & -71.90 & -65.70 & -60.60 & -54.95 & -49.29 \\
\hline $\mathrm{H}_{3} 2 \mathrm{Cl}(\mathrm{L}(\mathrm{cr})$ & -57.25 & -49.37 & -40.13 & -31.56 & -23.00 \\
\hline $\mathrm{HgO}(\mathrm{rr})$ & 29.03 & 33.38 & 38.49 & 43.22 & 47.95 \\
\hline $\mathrm{Hg}(\mathrm{OH}) 2(5)$ & -82.02 & -73.01 & -62.43 & -52.63 & -42.84 \\
\hline $\mathrm{H} g \mathrm{~S}(\mathrm{~s})$ & -0.04 & 4.18 & 9.14 & 13.73 & 18.32 \\
\hline $\mathrm{HgSO4}(\mathrm{s})$ & -337.19 & -325.39 & -311.53 & -298.71 & -285.88 \\
\hline $\mathrm{HgSe}(s)$ & -1.84 & 2.28 & 7.11 & 11.58 & 16.06 \\
\hline$K C I(5)$ & -350.63 & -349.51 & -346.02 & -343.72 & -341.42 \\
\hline$k 20(c r)$ & -237.37 & -234.42 & -230.94 & -227.71 & -224.48 \\
\hline$k 2 S(c r)$ & -317.49 & -314.33 & -310.63 & -307.20 & -303.77 \\
\hline$K 2504(E r)$ & -1069.50 & -1058.90 & -1046.40 & -1034.70 & -1023.30 \\
\hline K2Se(5) & -277.18 & -273.98 & -270.21 & -266.73 & -263.24 \\
\hline Li20(cr) & -480.25 & -477.16 & -473.32 & -469.86 & $-46 t .40$ \\
\hline $\operatorname{Li} 2 S(5)$ & -405.49 & -4021.70 & -399.43 & -396.40 & -393.39 \\
\hline Li2504 (c) & -1079.70 & -1070.50 & -1058.70 & -1048.20 & -1037.70 \\
\hline Li2Se (s) & $-364.5 !$ & -361.52 & -358.23 & -355.09 & -351.95 \\
\hline$N i(c r)$ & 0.000 & 0.00 & 0.00 & 0.00 & 0.00 \\
\hline $\mathrm{NIAs}(\mathrm{s})$ & -57.07 & -55.71 & -54.10 & -52.62 & -51.13 \\
\hline $\mathrm{NiCOZ}(\mathrm{s})$ & -453.33 & -447.32 & -441.35 & -435.35 & -429.36 \\
\hline $\mathrm{NiCl}$ (er) & -170.23 & -166.78 & -163.17 & -159.64 & -156.12 \\
\hline $\mathrm{NiO}(s)$ & -158.77 & -156.30 & -154.48 & -152.34 & -150.19 \\
\hline $\mathrm{Ni}(\mathrm{CH}) 2(\mathrm{~S})$ & -286.10 & -200.516 & -272.85 & -266.22 & -259.57 \\
\hline$N i S(E+)$ & -74.66 & -72.38 & -70.87 & -69.00 & -67.13 \\
\hline NiSz (cr) & -96.44 & -92.44 & -87.75 & -83.40 & -79.05 \\
\hline $\mathrm{Ni} 352(\mathrm{cr})$ & -187.21 & -184.72 & -132.23 & -179.74 & -177.25 \\
\hline$N i 354(\mathrm{~cm})$ & -246.04 & -239.67 & -231.26 & -223.47 & -215.63 \\
\hline NiSOA (E) & -553.23 & -544.13 & -533.44 & -523.55 & -513.65 \\
\hline NiSE $(s)$ & -73.46 & -71.69 & -69.61 & -67.69 & -65.76 \\
\hline
\end{tabular}


SOLID PHASE SPECIES (continued)

\begin{tabular}{|c|c|c|c|c|c|}
\hline TEMFERATURE: & $9100.0 \mathrm{~K}$ & $923.0 \mathrm{~K}$. & $950.0 \mathrm{~K}$ & $975.0 \mathrm{~K}$ & $1000.0 \mathrm{~K}$ \\
\hline N1SE2 (s) & -94.71 & -91.05 & -86.77 & -82.80 & -78.83 \\
\hline $\mathrm{Ni} 4 \mathrm{SeS}(\mathrm{s})$ & -314.56 & -306.41 & -296.37 & -287.08 & -277.78 \\
\hline $\mathrm{Ni} 7 \mathrm{Seg}(\mathrm{s})$ & -542.48 & -527.10 & -513.40 & -498.86 & -484.31 \\
\hline $\mathrm{NiSe03}(\mathrm{s})$ & -318.76 & -310.93 & -301.73 & -293.21 & -284.70 \\
\hline $\mathrm{Ni} 35 n(5)$ & -84.97 & -84.21 & -83.31 & -82.48 & -81.65 \\
\hline $\operatorname{Ni} 3 \sin 2(5)$ & -153.01 & $-151 \cdot 17$ & -149.01 & -147.01 & -145.01 \\
\hline $\mathrm{Ni} 35 n 4(5)$ & -169.41 & -166.55 & -163.20 & -160.10 & -156.99 \\
\hline $\mathrm{PbCO} 3(5)$ & -481.89 & -476.76 & -470.72 & -465.14 & -459.55 \\
\hline $\mathrm{PbCl}(\mathrm{er})$ & -227.43 & -224.28 & -220.59 & -217.17 & -213.75 \\
\hline $\mathrm{PbO}(\mathrm{er})$ & -129.18 & -126.92 & -124.25 & -121.79 & -119.32 \\
\hline $\mathrm{FbO} 2(\mathrm{Er})$ & -97.74 & -93.30 & -88.09 & -83.27 & -78.44 \\
\hline Fo304 (c) & -370.04 & $-361 . .37$ & -351.19 & -341.77 & -332.35 \\
\hline $\mathrm{Pb}(\mathrm{OH}) 2(\mathrm{~S})$ & -236.91 & -230.104 & -221.97 & -214.49 & -207.02 \\
\hline $\mathrm{PbS}(\mathrm{er})$ & -83.66 & -81.61 & -79.21 & -76.99 & -74.76 \\
\hline $\mathrm{PbSO} 4(5)$ & -589.07 & -579.22 & -567.65 & -556.93 & -546.22 \\
\hline FbSe(s) & -90.61 & -88.53 & -86.10 & -83.85 & -81.59 \\
\hline FoSe03(s) & -273.23 & -264.71 & -255.14 & -246.09 & -237.05 \\
\hline $5 n \operatorname{Co} 3(5)$ & -488.6 .5 & $-48: .75$ & -475.83 & -469.42 & -463.01 \\
\hline $\operatorname{sn}(\cos 3) 2(s)$ & -1038.90 & -1030.00 & -1019.40 & -1009.60 & -999.87 \\
\hline $\operatorname{SnO}(s)$ & -193.78 & -191.32 & -188.44 & -185.76 & -183.09 \\
\hline $5 n 02(5)$ & -394.98 & -390.33 & -384.87 & -379.82 & -374.76 \\
\hline $\operatorname{Sn}(O H) 2(5)$ & -314.37 & -307.59 & -299.63 & -292.26 & -284.89 \\
\hline $\mathrm{Sn}(\mathrm{OH}) 4(5)$ & -642.34 & -631.86 & -619.56 & -608.17 & -596.78 \\
\hline $\operatorname{SnS}(s)$ & -90.29 & -88.18 & -85.69 & -83.38 & -81.08 \\
\hline $\operatorname{sn} 5 ?(5)$ & -107.93 & $-10 I .49$ & -98.27 & -93.44 & -88.62 \\
\hline $5 n 253(5)$ & -200.66 & -194.16 & -186.52 & -179.45 & -172.38 \\
\hline $5 n 354(5)$ & -291.20 & -282.56 & -272.42 & -263.04 & -253.65 \\
\hline $\operatorname{sn} 504(5)$ & -704.19 & -695.69 & -685.71 & -676.47 & -667.23 \\
\hline $\operatorname{Sn}(504) 2(5)$ & -936.05 & -916.41 & -893.35 & -871.99 & -850.64 \\
\hline $\mathrm{SnSe}(5)$ & -91.7 .9 & 789.89 & -87.69 & -85.67 & -83.64 \\
\hline $\operatorname{SnEez}(5)$ & -97.67 & -93.41 & -88.39 & -83.74 & -79.09 \\
\hline $\operatorname{In} 3 A 52(5)$ & -100.74 & -97.53 & -93.76 & -90.27 & -86.77 \\
\hline $\ln \operatorname{Co} 3(5)$ & -.571 .36 & -565.53 & -558.69 & -552.36 & -546.03 \\
\hline $\operatorname{InO}(s)$ & -256.74 & -254.29 & -251.41 & -248.74 & -246.07 \\
\hline $\operatorname{In}(O H) 2(5)$ & -376.58 & -370.27 & -362.87 & -356.02 & -349.17 \\
\hline $\operatorname{lns}(s-s p h)$ & -180.910 & $-178,52$ & -175.72 & -173.13 & -170.54 \\
\hline $\mathrm{Zn} 504$ (cr) & $-\$ 41.57$ & -631.56 & -619.80 & -608.92 & -598.03 \\
\hline ZnSe (s) & -142.49 & -140.18 & $-137,47$ & -134.95 & -132.44 \\
\hline
\end{tabular}



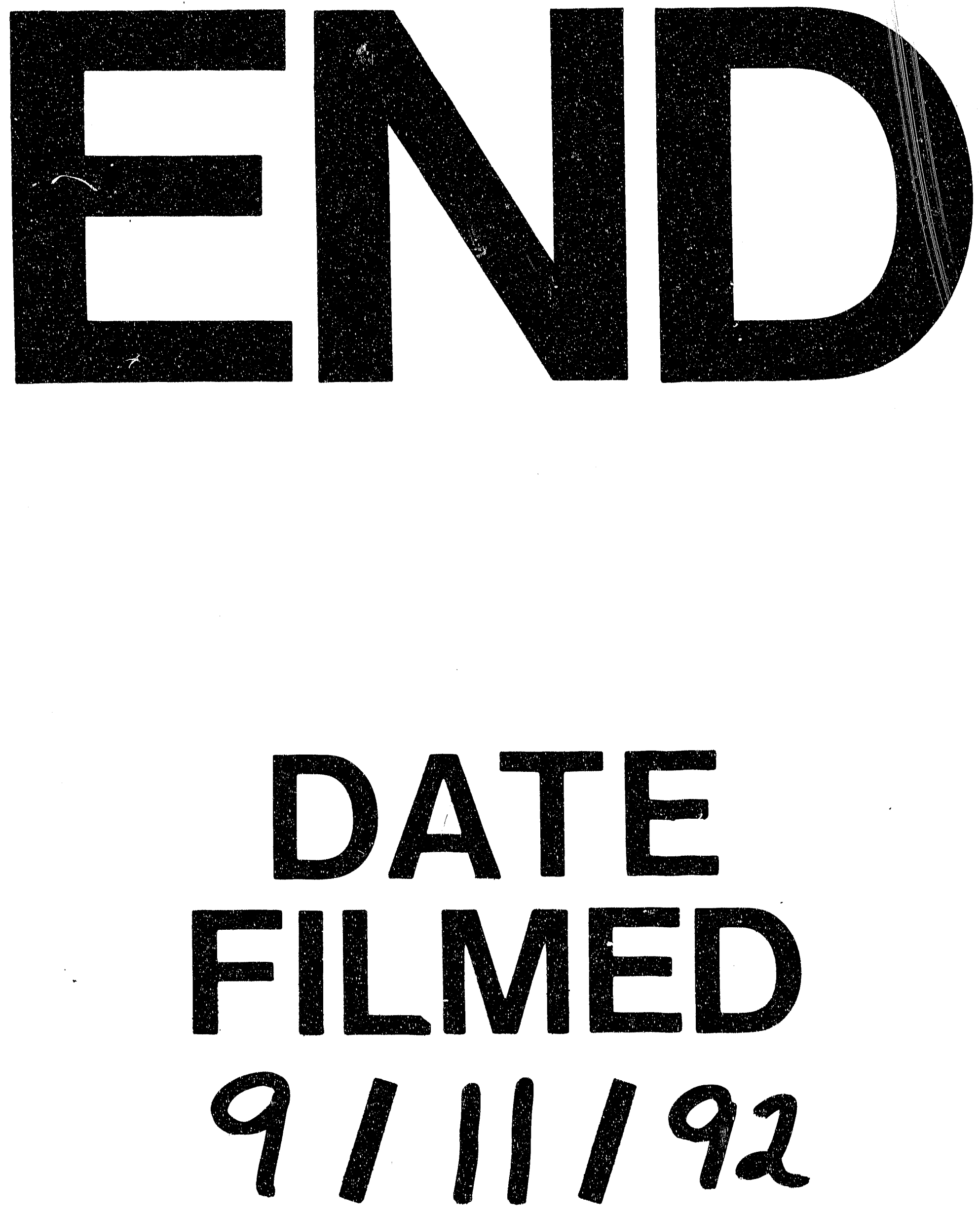